\title{
25. LATE CENOZOIC CARBONATE ACCUMULATION AND THE HISTORY OF THE CARBONATE COMPENSATION DEPTH IN THE WESTERN EQUATORIAL INDIAN OCEAN ${ }^{1}$
}

\author{
Larry C. Peterson ${ }^{2}$ and Jan Backman ${ }^{3}$
}

\begin{abstract}
The principal paleoceanographic objective of Ocean Drilling Program Leg 115 was to collect a suite of materials that would allow reconstruction of the dynamic features of the late Cenozoic carbonate system in the equatorial Indian Ocean. This goal was achieved with the recovery of sediments from a closely spaced depth transect (1541-4428 m) of five sites (Sites 707 through 711) from on and around the Mascarene Plateau that record the last 50 m.y. of pelagic deposition. More than 2200 measurements of carbonate content are combined here with a highly resolved bio- and magnetostratigraphy to produce the first detailed compilation of bulk, carbonate, and noncarbonate mass accumulation rates (MARs) from the Indian Ocean.

These results allow us to recognize three major depositional intervals, each characterized by a distinct depth-dependent pattern of carbonate accumulation: (1) the Paleogene, a time of moderate accumulation rates $\left(0.4-0.7 \mathrm{~g} / \mathrm{cm}^{2} / 1000\right.$ yr) and reduced between-site accumulation differences; (2) the early and middle Miocene, a period characterized by greatly reduced carbonate MARs (typically $<0.2 \mathrm{~g} / \mathrm{cm}^{2} / 1000 \mathrm{yr}$ ) at all sites and a shallow carbonate compensation depth; and (3) the late Miocene to Holocene, a time span marked by the highest bulk and carbonate accumulation rates of the last $50 \mathrm{Ma}\left(1.6-1.8 \mathrm{~g} / \mathrm{cm}^{2} / 1000 \mathrm{yr}\right)$, and the first appearance of substantial contrasts in carbonate accumulation as a function of the water depth of the drill site. The fundamentally different character of the carbonate system during each of these intervals must represent a regional response to the complex evolution of late Cenozoic oceans and climate.
\end{abstract}

\section{INTRODUCTION}

After a successful drilling cruise in the tropical Indian Ocean, the JOIDES Resolution returned to port at the end of Ocean Drilling Program (ODP) Leg 115 almost 40 yr to the day after the Swedish Deep Sea Expedition began its circumglobal voyage with Albatross in July 1947. That earlier expedition brought home piston cores, unique at the time, that Arrhenius (1950, 1952) first used to measure and describe time-dependent variability in the biogenic carbonate content of deep-sea sediments, variability which he attributed to rhythmic changes in ocean circulation and surface-water productivity caused by climatic forcing.

During the decades that have passed since Arrhenius's pioneering work on the Albatross cores, it has become increasingly clear that the development of well-constrained models of the deep-sea carbonate budget is a necessary prerequisite to understanding the history of both ocean circulation and global climate. This insight is derived from the fact that carbonate accumulation in open-ocean environments is primarily dependent upon the production rate of planktonic foraminifers and calcareous nannoplankton in the surface waters and their subsequent dissolution on the seafloor. Surface-water productivity is determined by the availability of nutrients, whereas dissolution is largely a function of the calcium carbonate saturation state of seawater at the sediment/water interface. Both processes are intimately linked to changes in surface- and deep-water circulation that control the rates of vertical mixing and the interbasinal distribution of nutrients, alkalinity, oxygen, and carbon (e.g., Broecker and Peng, 1982). Thus, spatial and temporal accumu-

\footnotetext{
${ }^{1}$ Duncan, R. A., Backman, J., Peterson, L. C., et al., 1990. Proc. ODP, Sci. Results, 115: College Station, TX (Ocean Drilling Program).

${ }^{2}$ Rosenstiel School of Marine and Atmospheric Science, University of Miami, Miami, FL 33149, U.S.A.

${ }^{3}$ Department of Geology, University of Stockholm, Stockholm, Sweden.
}

lation patterns of biogenic carbonate on the seafloor represent primary sources of data about the carbonate chemistry and circulation of past oceans, and the global geochemical cycle of $\mathrm{CO}_{2}$.

Leg 115 represents the first scientific drilling in the Indian Ocean to take advantage of the advanced piston core/extended core barrel (APC/XCB) system, a system designed for retrieving largely undisturbed sediment cores at recovery rates near $100 \%$. The principal paleoceanographic objective of Leg 115 was to use this new technology to recover a depth transect of continuously cored sedimentary sequences from the tropical Indian Ocean that would allow reconstruction of the dynamic features of the regional carbonate system through the late Cenozoic. Deep-sea drilling has long since established that dissolution levels in the different ocean basins have fluctuated markedly during the Cenozoic (e.g., Berger and Winterer, 1974; van Andel, 1975; Heath et al., 1977; Hsü et al., 1984; Rea and Leinen, 1985). In general, these studies have shown that long-term changes in the patterns of carbonate distribution have been similar between the major ocean basins, suggesting a global forcing mechanism perhaps linked to changing sea level or to a changing supply of carbonate to the oceans (Kennett, 1982). Over the shorter term, however, distinct interocean differences in this general pattern have been found to exist that are likely related to basin-tobasin fractionation of carbonate (Berger, 1970) through changes in deep circulation, surface productivity, or interbasinal hypsometry.

In the Indian Ocean, previous efforts to reconstruct the late Cenozoic history of carbonate sedimentation (van Andel, 1975; Sclater et al., 1977; Kidd and Davies, 1978) have been limited by the lack of suitable stratigraphic sequences available for study. Leg 115 met its objective of providing such a set of high-quality records with the drilling of a five-site depth transect (Sites 707711 ) on the Northern Mascarene Plateau, the Madingley Rise, and the adjacent basin floor (Fig. 1). In this paper, we present the first detailed compilation of bulk sediment, carbonate, and noncarbonate mass accumulation rates (MARs) from the In- 


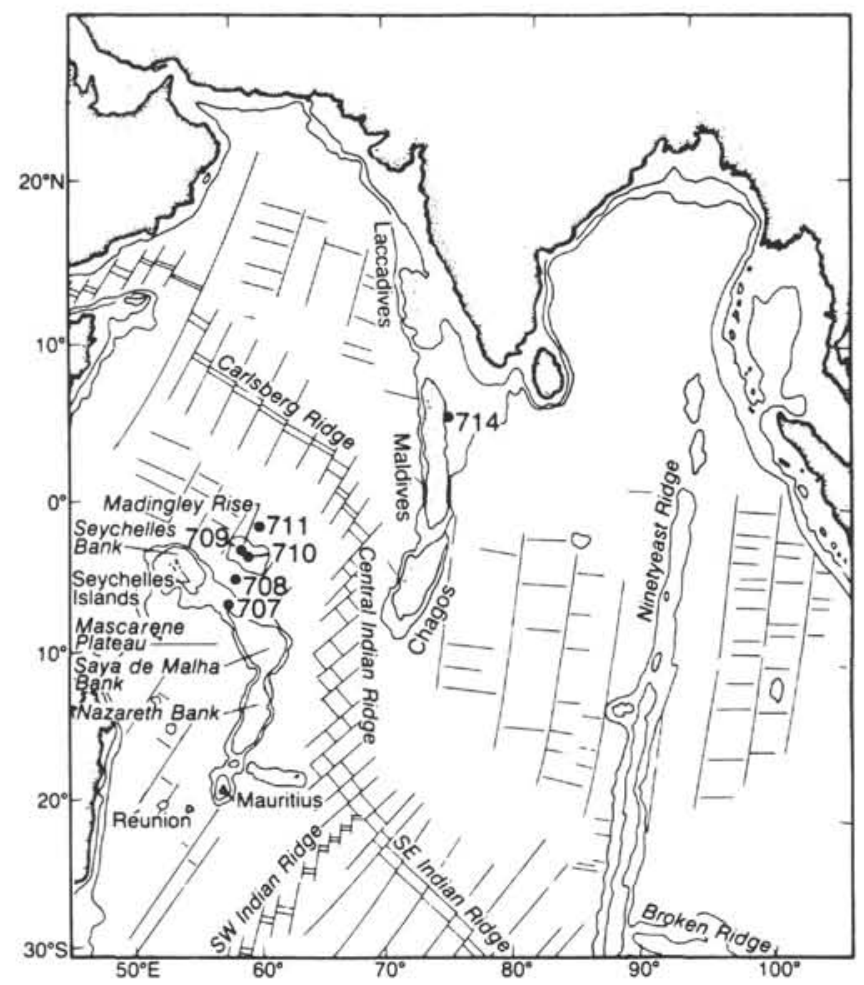

Figure 1. Location of Leg 115 drill sites considered in this study. Sites 707 through 711 comprise a bathymetric transect in the western equatorial Indian Ocean that was drilled to allow study of late Cenozoic variability in the pelagic carbonate system. Site 714, drilled on the Maldives Ridge, recovered an exceptional Miocene sequence and provides comparative data on carbonate accumulation patterns during this interval.

dian Ocean, based on more than 2200 measurements of carbonate content from these five sites, combined with a highly resolved bio-and magnetostratigraphy. We also present similar results from Site 714, a more geographically distant site drilled on the eastern shoulder of the Maldives Ridge to the north of the equator. This shallow site $(2031 \mathrm{~m})$ is particularly noteworthy because of its exceptional Miocene sequence, the most expanded and complete section of lower through lower upper Miocene sediments recovered on Leg 115 . Together, our data provide significant insight into the patterns of pelagic sedimentation and of carbonate accumulation and dissolution in the tropical Indian Ocean during the last 50 m.y..

\section{REGIONAL SETTING, MATERIALS, AND METHODS}

The Indian Ocean differs from the Atlantic and Pacific oceans in its northern landlocked nature, its physiographic complexity, and in its strong monsoonal circulation in the tropical surface ocean and atmosphere. These factors result in water masses and circulation patterns that are distinctly different from those found in the other major ocean basins.

The surface oceanography of the northern and equatorial Indian Ocean is dominated by the seasonally changing monsoonal gyre, which is caused by the complete reversal of the prevailing wind field between the Southwest and Northeast monsoons. Surface waters of this reversing gyre tend to be separated from surface waters of the subtropical gyre to the south by a distinct hydrochemical front located today near approximately $10^{\circ} \mathrm{S}$ (Wyrtki, 1973). Surface waters to the north of this hydrochemical boundary have high nutrient levels and a correspondingly high produc- tivity, whereas to the south they are characterized by low levels of both, an observation clearly reflected in the distribution of biogenic opal in the underlying surface sediments (e.g., Leinen et al., 1986).

Below the surface layer, the deep Indian Ocean is filled with deep and bottom waters that have their origins in the North Atlantic and Antarctic, respectively, as no such waters are presently formed in the basin (Tchernia, 1980; Warren, 1981). At intermediate water depths, however, a high-salinity water mass, largely of Red Sea and Persian Gulf origins, fills much of the mid-depths of the northwestern Indian Ocean (Wyrtki, 1973). This northern Indian Ocean Intermediate Water can be traced today to depths of $1500 \mathrm{~m}$ and as far south as the Mascarene Plateau, where it mixes with northward-flowing Antarctic Intermediate Water.

The five closely spaced sites of the Leg 115 transect (Fig. 1) range in water depth from 1541 (Site 707) to $4428 \mathrm{~m}$ (Site 711), a depth interval that encompasses the present range of intermediate-, deep-, and bottom-water masses in the area. The sites currently lie to the north of the hydrochemical front at $10^{\circ} \mathrm{S}$ described by Wyrtki (1973) and thus receive their pelagic input today from the highly productive surface waters of the equatorial belt. Tectonically, the transect sites are attached to the African Plate; plate reconstructions (e.g., McKenzie and Sclater, 1971) indicate that their positions should have changed little with respect to the equator over the time span covered by this study.

By studying materials from sites that cover a wide range of water depths within a limited geographic area, past carbonate dissolution gradients can be reconstructed that are largely free of regional variability in surface productivity and deep-water circulation patterns. The calcium carbonate dissolution gradient in the ocean can be thought of as extending from the lysocline, the level at which carbonate dissolution becomes clearly apparent (Berger, 1968, 1975), to the carbonate compensation depth (CCD), the still deeper level separating carbonate-bearing sediments above from carbonate-free sediments below (Bramlette, 1961). At present, the lysocline in the equatorial Indian Ocean occurs at about 3800-4000 m (Kolla et al., 1976; Peterson and Prell, 1985), and the CCD is found at about $5200 \mathrm{~m}$ (van Andel, 1975; Kolla et al., 1976).

Site 707 is the shallowest site of the transect $(1541 \mathrm{~m})$ and is located on the Mascarene Plateau in the saddle between the Seychelles and Saya de Malha banks (Fig. 1). Sedimentation at this site has been entirely pelagic over the stratigraphic interval for which we have data $(0-38 \mathrm{Ma})$, with sediments consisting primarily of foraminifer and nannofossil oozes. Site 708 is located near the deeper end of the transect at a water depth of $4096 \mathrm{~m}$ on the abyssal plain some $150 \mathrm{nmi}$ to the north. Sediments of Site 708 record a history of alternating pelagic and turbidite deposition. In general, the turbidites could be readily identified by their light colors and high carbonate contents, and by the shallow-water affinities of the benthic foraminifer assemblages within. Their light colors typically caused them to stand out clearly from the darker foraminifer-bearing nannofossil oozes and clayrich nannofossil oozes that form the bulk of the pelagic sequence at this deep site. Sites 709,710 , and 711 were drilled at water depths of 3038,3812 , and $4428 \mathrm{~m}$, respectively, on the crest and flanks of the Madingley Rise, a regional topographic high to the north of the Mascarene Plateau and Site 708. Sediments at these sites generally consist of nannofossil oozes, clayrich nannofossil oozes, and carbonate-free clays, distributed by depth and by time of deposition and clearly indicating a complex and variable dissolution history.

Site 714 is located in the northern equatorial Indian Ocean at a water depth of $2031 \mathrm{~m}$ (Fig. 1). The site lies on the eastern shoulder of the Maldives Ridge, which itself forms part of the aseismic ridge complex extending northward on the Indo-Aus- 
tralian Plate from the Chagos Bank to the Laccadive Islands. Originally targeted as a location for sampling late Neogene periplatform sediments shed from the adjacent carbonate banks, Site 714 is punctuated by a major hiatus spanning the time interval between the late Pleistocene and the late Miocene. The remainder of the Miocene sequence, however, was found to be characterized by excellent preservation of foraminifers and calcareous nannofossils and a fairly complete, expanded section. Data from this interval are included in this report.

Samples for carbonate analysis were collected from the five transect sites at the approximate rate of three to four samples per 1.5-m core section. For Site 714, carbonate content was analyzed at the rate of two to three samples per section. Within any one core section, the sampling interval was not always regular since considerable care was taken to avoid sampling intervals of core that showed obvious signs of sedimentary disturbance, such as slumped and stratigraphically disordered materials, or turbidites. Carbonate content was determined on board the JOIDES Resolution with a Coulometrics Carbon Dioxide Coulometer for samples taken at an average initial frequency of two samples per section. For the transect sites, the shipboard data base was supplemented with an additional one to two shore-based measurements per section made with a modified (non-vacuum) version of the gasometric carbonate apparatus described by Jones and Kaiteris (1983). Each technique by itself has an analytical precision of $<1 \%$ by weight based on replicate analyses; an intercomparison of the two techniques based on analysis of $\simeq 50$ common samples indicates that the two methods give virtually identical results (standard deviation of the differences $=0.4 \%$ ).

The MAR calculations for Leg 115 sediments were made for each sample in which the carbonate content was analyzed. Individual sample estimates are based on simple computations involving the sedimentation rate $(\mathrm{cm} / 1000 \mathrm{yr})$, the dry-bulk density of the sediment $\left(\mathrm{g} / \mathrm{cm}^{3}\right)$, and the measured weight percent $\mathrm{CaCO}_{3}$. Direct measurements of dry-bulk density were generally available from the shipboard work (Backman, Duncan, et al., 1988) at the rate of two to three per core and thus are far fewer than the number of carbonate content analyses. Because of the disparities in the sampling intervals for these data, some sort of averaging technique was required to account for carbonate samples positioned between those samples for which both carbonate and dry-bulk density were analyzed. Of a number of possible approaches, we chose to use the measured dry-bulk densities of the pertinent samples, and to use the mean value of adjacent dry-bulk density measurements for the in-between samples from which carbonate content alone was measured. The resulting estimates of bulk sediment, carbonate, and noncarbonate MARs, as well as the raw data on sample sub-bottom depth, sample age, and measured carbonate content $(\mathrm{wt} \%)$ can be found in Appendix A.

Because bulk sedimentation rates vary over the five depth transect sites between 1 and $20 \mathrm{~m} / \mathrm{m}$.y., the temporal resolution of our sampling for this study ranges between about 2 and 80 samples/m.y. On average, however, a sampling interval of approximately $75-120 \mathrm{k}$.y. was maintained for a large portion of the transect sequence. This sample interval provides an opportunity to study the Indian Ocean carbonate system at a resolution heretofore impossible with older, existing Deep Sea Drilling Project (DSDP) materials.

\section{RESULTS}

\section{Stratigraphy and Age Models}

Stratigraphies for the sites discussed here are based on bioand magnetostratigraphic data collected during the shipboard work (Backman, Duncan, et al., 1988) as well as subsequent shorebased efforts (Okada, this volume; Rio et al., this volume;
Schneider and Kent, this volume). Our age control comes from the placement of these data within the framework of the geomagnetic polarity time scale of Berggren et al. (1985a, 1985b). Because the determination of sediment MARs is heavily dependent on the resulting chronologies, a detailed discussion of our age-model development for each site is presented in Appendix B.

As reported by Schneider and Kent (this volume), Sites 710 and 711 yielded fairly complete and unambiguous magnetostratigraphic results for intervals recovered with the APC. The age models for these intervals, which include most of the Neogene at both sites, are based on a combination of paleomagnetic and biochronologic data. Unfortunately, no magnetostratigraphic information exists from Sites 707 and 708, and Site 709 yielded only limited data. The age models for these latter three sites, as well as for sediments from Sites 710 and 711 recovered below the APC-cored intervals, are based solely on biostratigraphic data.

The set of critical microfossil events that formed the basis for our age models is presented for each site in Table 1 . The age estimates used for these datums are mainly those listed and referenced in the Leg 115 Initial Reports ("Explanatory Notes" chapter in Backman, Duncan, et al., 1988). We also take into account, however, certain revisions to age estimates for Miocene nannofossil events, derived on the basis of Leg 115 results and summarized by Backman et al. (this volume). Our age quotations for Pliocene-Pleistocene datums are given to two decimal places, whereas pre-Pliocene datums are given to one, following the biochronologic literature we have used. Where we have used geomagnetic reversal boundaries as control points, their age estimates are given with two decimals (Berggren et al., 1985a, 1985b).

The biochronological control points listed in Table 1 are notable in that they represent only nannofossil events. There are several reasons for our bias toward the use of a single microfossil group in this study. First, the calcareous nannofossils have the most consistent stratigraphic distribution in the investigated sections. Planktonic foraminifers, for example, were found to be virtually absent in most Paleogene sections, as well as in large portions of the early Neogene where they were removed by carbonate dissolution. Second, at least for the time being, the nannofossil biostratigraphy of these sites has been determined with a considerably closer sample spacing (commonly much less than $1 \mathrm{~m}$ ) than the other microfossil groups, implying somewhat better constrained sedimentation rates. Third, we consider the current precision in the biostratigraphic intercalibration between calcareous and siliceous microfossil groups to be less than satisfactory for our purposes. Despite these biases, we note that the age/depth indications provided by the various microfossil groups in these sites are nevertheless often quite similar. Thus, we view our biochronologic framework constructed on the basis of calcareous nannofossils as a somewhat filtered, although representative, signal that fits well with the general body of biostratigraphic information.

Age models for the transect sites (Figs. 2-4) are fairly well constrained, except for some intervals in the early Miocene/Oligocene sections that suffer from limitations in terms of resolution (i.e., number of datum events, or potential control points, per unit time) and biochronologic precision. The latter limitation is largely a result of the lack of adequate magnetostratigraphic reference sections available from tropical, pre-late Pliocene sediments. In constructing our age models, we attempted to use identical sets of datum events for each of the transect sites so that errors in age/depth estimates and sedimentation rates that result from faulty calibration ages are at least consistent throughout the sites studied.

Even under the best of conditions, there are a number of problems and processes that potentially blur the age/depth con- 
Table 1. Control points used to estimate sedimentation rates.

\begin{tabular}{cccc}
\hline $\begin{array}{c}\text { Control } \\
\text { points } \\
\text { (mbsf) }\end{array}$ & $\begin{array}{c}\text { Depth } \\
\text { interval } \\
\text { (mbsf) }\end{array}$ & $\begin{array}{c}\text { Age } \\
(\mathrm{Ma})\end{array}$ & $\begin{array}{c}\text { Sedimentation } \\
\text { rate } \\
(\mathrm{m} / \mathrm{m} . \mathrm{y} .)\end{array}$ \\
\hline
\end{tabular}

Site 707:

top-LO C. macintyrei (9.70)

LO $R$. pseudoumbilica (26.85)

FO Amaurolithus spp. (80.55)

LO D. hamatus (104.85)

FO C. coalitus $(116.25)$

LO $S$. heteromorphus $(122.65)$

FO $S$. heteromorphus $(133.65)$

LO $S$. ciperoensis (141.50)

LO $D$. barbadiensis (202.40)

$0-9.70$
$9.70-26.85$
$26.85-80.55$
$80.55-104.85$
$104.85-116.25$
$116.25-122.65$
$122.65-133.65$
$133.65-141.50$
$141.50-210.40$

$0-1.45$
3.56
6.7
8.7
11.1
13.6
18.4
25.2
37.0

(m/m.y.)

Site 708:

top-LO P. lacunosa $(2.90)$
LO $C$. macintyrei $(16.80)$
LO $D$. tamalis $(30.30)$
LO $R$. pseudoumbilica $(35.80)$
LO D. quinqueramus $(51.00)$
FO Amaurolithus spp. $(74.50)$
LO D. hamatus $(88.50)$
FO C. coalitus $(95.60)$
FO $S$. heteromorphus $(107.80)$
FO $S$. belemnos $(107.80)$
LO $S$. ciperoensis $(136.30)$
FO $S$. ciperoensis $(166.00)$

${ }^{\mathrm{a}} 0-2.90$

2.90-16.80

$16.80-30.30$

$30.30-35.80$

$35.80-58.83$

74.97-88.50

$88.50-95.60$

95.60-107.80

107.80-136.30

$136.30-177.59$

Hole 709A: top-base Brunhes (9.00)

base Olduvai (21.35)

base Matuyama (26.05)

base Gauss (33.25)

FO Amaurolithus spp. (87.30)

LO D. hamatus (110.10)

LO $S$. heteromorphus (122.40)

base C6CN2 (187.20)

top C7N1 (197.20)

$0-9.00$

9.00-21.35

21.35-26.05

26.05-33.25

$33.25-87.30$

$87.30-110.10$

$110.10-122.97$

b 174.75-197.07

$\begin{array}{lr}0-0.46 & 6.30 \\ 1.45 & 14.04 \\ 2.65 & 11.25 \\ 3.56 & 6.04 \\ 5.00 & 10.56 \\ 6.7 & \\ 8.7 & 7.00 \\ 11.1 & 2.96 \\ 18.4 & 1.67 \\ 20.0 & \\ 25.2 & 5.48 \\ 30.2 & 5.94\end{array}$

Hole 709C:

LO $S$. ciperoensis $(200.00)$

LO D. barbadiensis (285.10)

LO C. gigas (349.50)

200.00-285.10

285.10-353.15

$\begin{array}{lr}0-0.73 & 12.33 \\ 1.88 & 10.74 \\ 2.47 & 7.97 \\ 3.40 & 7.74 \\ 6.7 & 16.38 \\ 8.7 & 11.40 \\ 13.6 & 2.51 \\ 23.79 & \\ 25.50 & 5.85\end{array}$

Site 710:

top-top Olduvai (15.40)

LO D. brouweri $(18.50)$

top Gauss (20.10)

LO D. tamalis $(22.20)$

base Sidufjall (37.00)

top C4AN1 $(74.20)$

top C5N1 $(80.00)$

FO C. coalitus $(90.30)$

base C5ACN1 $(98.50)$

base C5BN1 (105.20)

top C5CN1 $(109.70)$

base C6ANI $(120.00)$

base C6AAN2 (124.70)

LO $S$, ciperoensis $(142.25)$

LO $S$. distentus $(164.80)$

FO $S$. ciperoensis $(181.60)$

$0-15.40$

$14.50-19.20$

19.20-23.55

$29.05-74.20$

$74.20-80.00$

$80.00-92.45$

97.15-105.20

$105.20-109.70$

$110.25-120.00$

$120.00-124.70$

$124.70-142.25$

$164.80-206.01$

25.2
37.0

47.0

Site 711:

top-top Jaramillo (7.70)

LO C. macintyrei $(8.60)$

top Olduvai ${ }^{c}(9.80)$

base Thvera $(20,30)$

top C4N1 $(33.80)$

$0-8.10$
$8.10-9.80$
$9.80-20.30$
$20.30-33.80$

top C7N1 (79.90)

top C9N1 $(98.80)$

LO $D$. barbadiensis $(158.20)$

LO C. gigas (219.70)

FO C. gigas $(231.50)$
78.45-98.80

98.80-158.20

$158.20-219.70$

$219.70-236.15$

$\begin{array}{cr}0-0.91 & 8.46 \\ 1.45 & \\ 1.66 & 5.71 \\ 4.77 & 3.38 \\ 6.70 & 6.99 \\ 33.80-39.20 & \mathrm{~d}_{3.87} \\ 39.75-45.20 & \mathrm{~d}_{1.40} \\ 46.15-67.35 & \mathrm{~d}_{2.17} \\ 25.50 & \\ 28.15 & 7.13 \\ 37.0 & 6.71 \\ 47.0 & 6.15 \\ 48.8 & 6.56\end{array}$

Table 1 (Continued).

\begin{tabular}{|c|c|c|c|}
\hline $\begin{array}{l}\text { Control } \\
\text { points } \\
\text { (mbsf) }\end{array}$ & $\begin{array}{l}\text { Depth } \\
\text { interval } \\
\text { (mbsf) }\end{array}$ & $\begin{array}{c}\text { Age } \\
(\mathrm{Ma})\end{array}$ & $\begin{array}{l}\text { Sedimentation } \\
\text { rate } \\
\text { (m/m.y.) }\end{array}$ \\
\hline \multicolumn{4}{|l|}{ Site 714: } \\
\hline top-LO P. lacunosa $(18.00)$ & $0-19.40$ & $0-0.46$ & 39.13 \\
\hline LO D. hamatus $(33.15)$ & & 8.7 & \\
\hline LO $S$. heteromorphus (87.55) & $20.20-87.55$ & 12.6 & 11.10 \\
\hline FO $S$. heteromorphus (163.15) & $87.55-163.15$ & 18.4 & 15.75 \\
\hline LO $S$. ciperoensis (196.45) & $163.15-226.60$ & 25.2 & 4.90 \\
\hline
\end{tabular}

Note: $\mathrm{FO}=$ first occurrence and $\mathrm{LO}=$ last occurrence.

a Depths reported for Site 708 are recalculated depths obtained after subtracting all turbidites $>0.4 \mathrm{~m}$ from the sequence (see text and Appendix A).

b No data were used between 123 and 174 mbsf in Hole 709A because of the disturbed stratigraphy (see discussion in Appendix B).

${ }^{c}$ Inferred from Hole 711B through magnetic susceptibility correlations.

d Inferred from Hole 711B; see text.

trol of a drilled or cored sedimentary sequence, including inaccurate biochronologic control, problems unique to the coring process (see review by Ruddiman et al., 1987), sediment reworking, and differing biostratigraphic methodologies between investigators. Given these potential sources of error, we have tried to make allowance for minor offsets of even supposedly good age indications along the interpolated/extrapolated sedimentation rate lines in Figures 2-4. In practice, this means that our sedimentation rate lines, rather than trying to account for every possible wiggle, represent smoothed estimates between control points at which definitive changes in rate are indicated. We consider the possible consequences of this smoothing process to our MAR calculations to be of less concern than potential artifacts introduced into our data by insufficient time controls.

\section{Carbonate Stratigraphy}

Downhole variations in the carbonate content of sediments from the five-site depth transect are plotted as a function of sub-bottom depth in Figure 5. The shallower sites, plotted to the left of the figure, display little variation in carbonate content, whereas the deeper sites display considerable downhole change. In any single record, possible causes for carbonate variations can include changes in the input fraction of noncarbonate dilutant, changes in the rate of biogenic carbonate production in the overlying surface waters, and/or changes in the amount of dissolution at depth. The bathymetry of the study area largely precludes direct terrigenous dilution at these sites, although variability in the noncarbonate fraction can also come from input changes of such materials as biogenic opal and volcanic ash. As a rule of thumb, one anticipates that productivity variations will influence the carbonate record most heavily at shallower sites, and dissolution likewise at deeper sites. Separating the effects of these latter two processes is a difficult proposition, however, particularly with carbonate data expressed in percentage form. Nevertheless, the fact that carbonate variability is systematically greater in the deeper sites would appear to implicate changes in the depth-dependent dissolution gradient as having an important control over these patterns.

The carbonate records of the five individual sites can be more easily compared when plotted together (Fig. 6) as a function of estimated age using the age models discussed above. To simplify this figure, the carbonate data were first smoothed slightly with a five-point running mean. Carbonate variations can be seen to correlate well between sites when viewed in the temporal framework of Figure 6, with the most dramatic varia- 


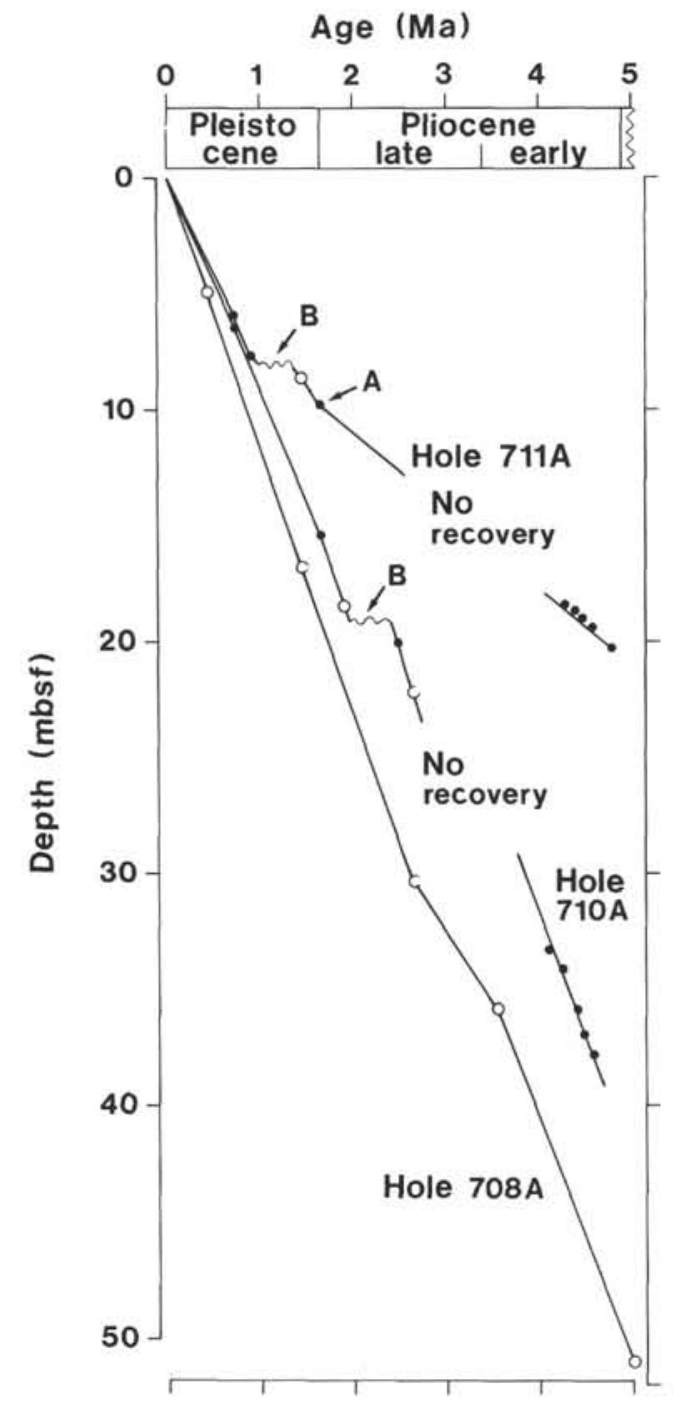

Figure 2. Estimated sedimentation rates within the Pliocene-Pleistocene sections of Holes 708A, 710A, and 711A.

tions visible in the record of Site 711 , the deepest site in the transect. Through most of the Neogene, Site 711 was clearly near or below the CCD. In fact, three discrete intervals largely barren of calcareous microfossils can be recognized in Site 711 sediments: (1) the late early to early middle Miocene, (2) the late middle to early late Miocene, and (3) the late Miocene to early Pliocene. These intervals of clay accumulation $\left(0 \%-5 \% \mathrm{CaCO}_{3}\right)$ at Site 711 are separated from each other by nannofossil clays with carbonate contents ranging between $20 \%$ and $40 \%$. Although much of the Miocene sequence at this site is strongly condensed, with average sedimentation rates of only 1-2 m/ m.y., deposition appears to have been continuous within the limits of stratigraphic resolution (see Appendix B).

Parallel variations in carbonate content in the Neogene sequence are visible in the records of Sites 708 and 710, although they are progressively reduced in amplitude. In Site 708, carbonate content drops nearly to zero only in the late middle to early late Miocene interval, indicating a shoaling of the CCD to close to the paleodepth of this site at this time. Parallel variations are also visible in the records of Sites 707 and 709, but are less easy to detect because of the low amplitude of their carbonate signals.

Before early Miocene time, the carbonate content at all sites was uniformly high $(80 \%-90 \%)$ except for a few distinct lowcarbonate events in Site 711 near the middle/late Eocene boundary. These events, because of their brief nature, show up more clearly in the unfiltered carbonate record of Figure 5 near subbottom depths of 175 and $185 \mathrm{~m}$. Calcareous nannofossils account for the bulk of the carbonate in the carbonate-rich Paleogene sections of each of the longer transect records.

Carbonate variations in Hole 714A are also plotted in Figure 5 as a function of sub-bottom depth, although they are more difficult to compare directly with variations in the other five sites because of the major hiatus near the top of the cored sequence and because Site 714 is considerably removed from the tightly clustered transect. Carbonate content in Hole 714A varies between about $60 \%$ and $90 \%$ and shows a general tendency to increase downhole. The fact that carbonate content at this site is more variable than at Site 709 , a site deeper by about 1 $\mathrm{km}$, can probably be attributed to the greater abundance of siliceous microfossils in Hole $714 \mathrm{~A}$ sediments, as well as the closer proximity of the site to terrigenous sources.

\section{Accumulation Histories for the Transect Sites}

Any attempt to model the sediment budget of the oceans and its variability in the past requires knowledge of the rates at which the principal sedimentary components accumulate through time. The underlying rationale for converting component relative abundance data into estimates of component MARs has been discussed extensively by van Andel et al. (1975), Moore et al. (1984), Pisias and Prell (1985), and Broecker and Peng (1987).

Figures 7-12 illustrate time series of bulk sediment, carbonate, and noncarbonate MARs plotted separately for each site. Of the parameters used to construct the MAR records, the estimates of sedimentation rate are clearly what drive the overall calculations. More than anything else, plateaus in the MAR curves tend to reflect intervals where sedimentation rates are assumed constant, whereas sharp changes in MAR almost without exception stem from similar changes in sedimentation rate. We anticipate that, in reality, plateaus in accumulation are not only more variable than shown, but also that sharp transitions or steps in MAR are probably much smoother than shown. The accuracy of the long-term trends and variability in MARs is ultimately most dependent on the quality of our age models, and not on the precision of our lithologic measurements.

When seeking to interpret MAR events of short duration, one must also consider the consequences of chronologic resolution on the data. Take, for example, a short interval where carbonate content is low because of enhanced dissolution. The resulting decrease in carbonate MAR will in most cases automatically cause an increase in the noncarbonate MAR (computed as the difference between bulk and carbonate MARs) since such events predominantly occur over longer stratigraphic intervals where sedimentation rates are assumed to be constant. Such a link, of course, is hardly warranted since carbonate dissolution should have no bearing on the true flux of the noncarbonate component into the sediment; thus, the "closed-sum" problem inherent to data expressed in percentage form is not totally avoided in the MAR domain, and care needs to be taken when interpreting short-term events in the record.

Despite these problems, we are confident that the long-term MAR history presented here is fairly accurate by present stan- 


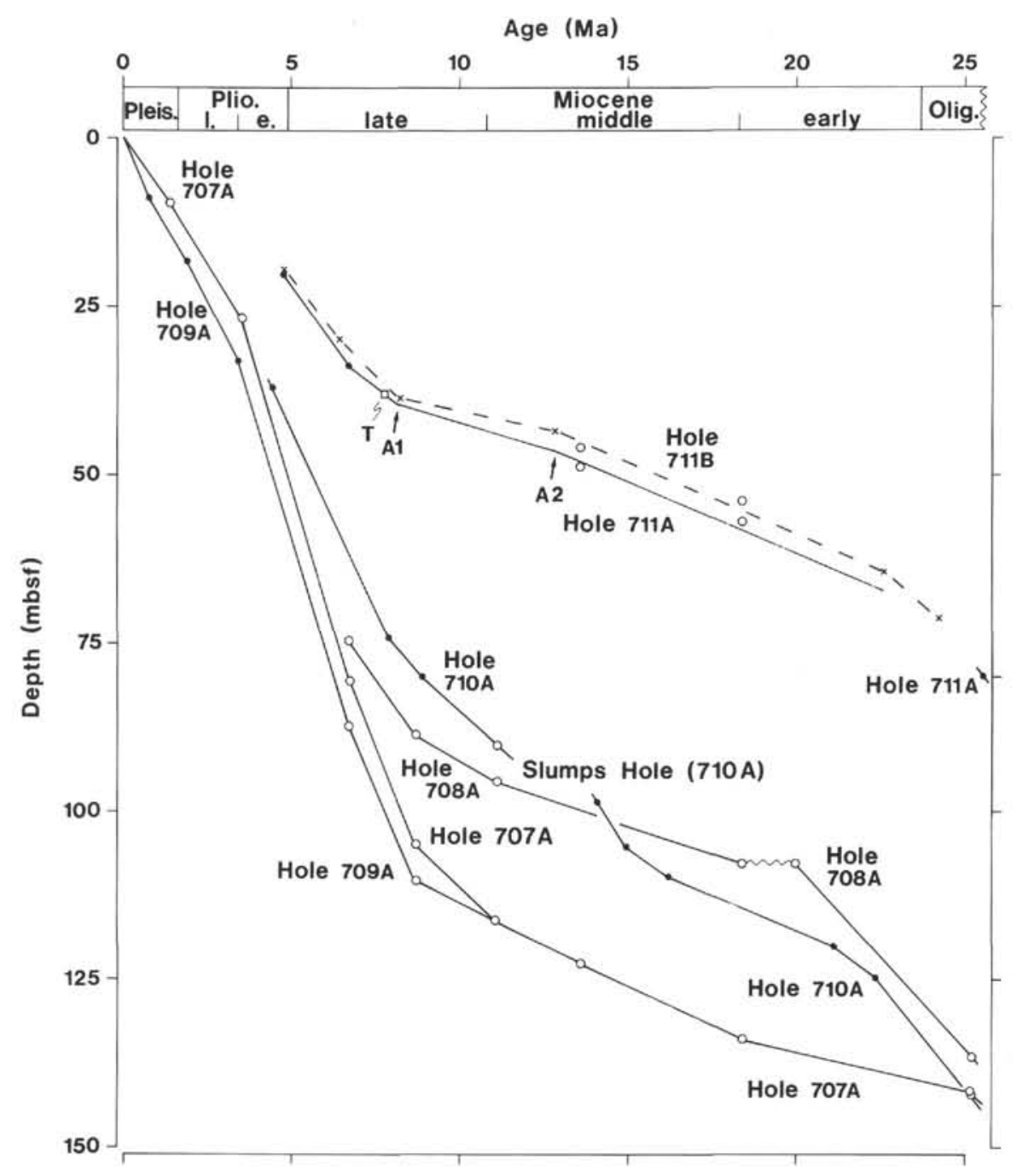

Figure 3. Estimated Neogene sedimentation rates for Holes 707A through 711A.

dards, and we feel that much of the short-term (carbonate) variability is probably real and accurately portrayed as well.

\section{Hole $707 A$}

Site 707, the shallowest site in the depth transect, was drilled on the assumption that the effects of carbonate dissolution would have minimal influence on its sediments, thus preserving a record of dominantly surface input in the MAR data. As noted above, carbonate contents are generally in excess of $90 \%$ throughout Hole 707A with only minor variability in the record (Fig. 5). These factors account for the nearly identical nature of the bulk sediment and carbonate MARs at this site (Fig. 7). The sharp changes in bulk and carbonate MARs at 25.2, 11.1, 8.7, 6.7 , and $3.5 \mathrm{Ma}$, respectively, are thought to represent real transitions in net accumulation, although the abruptness of the events is probably exaggerated by insufficient time controls (the Oligocene gap from 27.3 to $31.5 \mathrm{Ma}$ reflects recovery problems). Noncarbonate input to the site has been generally low $(<0.1$ $\mathrm{g} / \mathrm{cm}^{2} / 1000 \mathrm{yr}$ ) except in the late Miocene and early Pliocene, where increased, and variable, opaline silica accumulation occurs (see Backman, Duncan, et al., 1988, p. 245).

Paleogene carbonate MARs at Site 707 range between about 0.4 and $0.6 \mathrm{~g} / \mathrm{cm}^{2} / 1000 \mathrm{yr}$ (Fig. 7). The late Eocene through
Oligocene section consists mainly of nannofossil oozes, with foraminifers making up less than $10 \%$ of the sediments. Calcareous nannofossil preservation is generally good to moderate throughout, while planktonic foraminifer preservation varies from moderately good in the Oligocene to moderately poor in the late Eocene (Backman, Duncan, et al., 1988). Radiolarians, and more sporadically, diatoms, are found throughout the whole sequence, indicating a level of siliceous productivity and/or bottom conditions commensurate to their preservation.

The relatively steady MARs that characterize the late Paleogene at Site 707 end more or less abruptly near the Oligocene/ Miocene boundary (Fig. 7). The drop in MARs recorded at about $25 \mathrm{Ma}$, and the extremely reduced MARs $\left(0.1-0.2 \mathrm{~g} / \mathrm{cm}^{2} /\right.$ $1000 \mathrm{yr}$ ) that follow in the early and middle Miocene, are probably in large part explained by increased winnowing and by the likely presence of several hiatuses of short duration (see Rio et al., this volume). Sediment texture is the variable that undergoes the most noticeable change throughout this interval, with sediments grading gradually from the fine-grained nannofossil oozes characteristic of the late Paleogene to the coarser foraminifer-nannofossil oozes that make up most of the Neogene section. Thiede (1974) reported similar textural trends in sediments from nearby Site 237 , with measured coarse fraction 


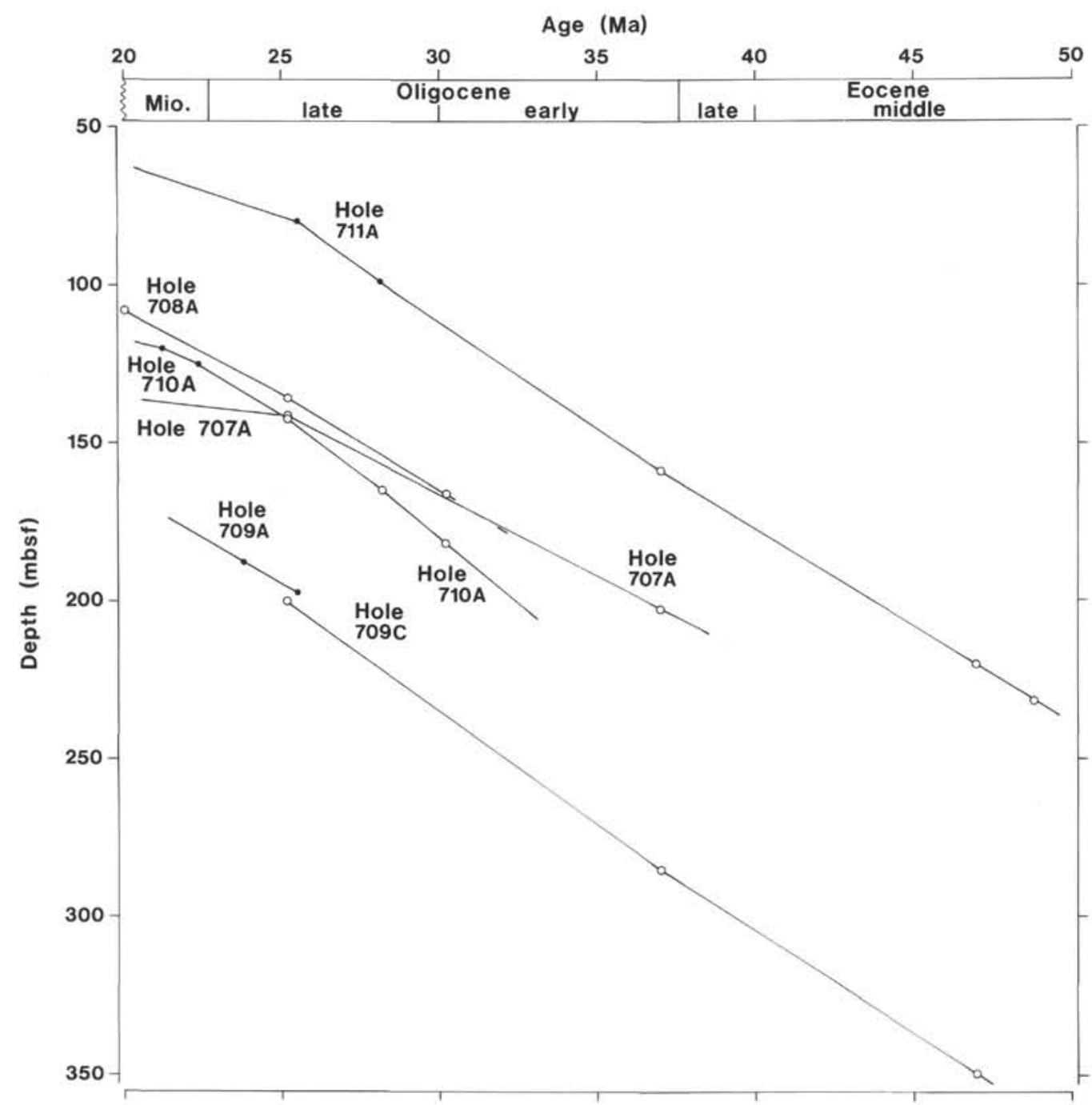

Figure 4. Estimated Paleogene sedimentation rates for Holes 707A through 711A.

( $>63 \mu \mathrm{m}$ ) percentages increasing from Oligocene values typically $<10 \%$ to values upward of $50 \%$ in the early Miocene (see fig. 4 of Thiede, 1974). At Site 707, observations of mixed foraminifer and nannofossil assemblages are most frequent in sediments of early and middle Miocene age (Backman, Duncan, et al., 1988; Rio et al., this volume), a result consistent with more intense reworking of the sediments.

Although current-induced winnowing and erosion most likely affected net accumulation at Site 707 during the early and middle Miocene, there is evidence that diminished surface productivity and increased carbonate dissolution may have played active roles as well. Support for a productivity argument can be marshalled from the observations of Mikkelsen (this volume) and Johnson (this volume) that siliceous microfossils, present in the late Paleogene sequence, disappear at about $25 \mathrm{Ma}$ and are absent in sediments of early and middle Miocene age. Increased carbonate dissolution can be inferred from shipboard observations that small-sized faunas dominate the planktonic foraminifer assemblages during this interval, and that the diversity of both planktonic and benthic foraminifer assemblages is low (Backman, Duncan, et al., 1988). The latter observations, coupled with clear evidence for contemporaneous dissolution in the deeper transect sites (see below), imply that the effects of disso- lution on carbonate MARs may even have been felt at the shallow paleodepth of this site.

The steplike rise in MARs that begins in the latest middle Miocene (11.1 Ma) and peaks in the late Miocene (5-6 Ma), with bulk MAR values as high as $1.6 \mathrm{~g} / \mathrm{cm}^{2} / 1000 \mathrm{yr}$, appears to be related to successively enhanced surface productivity, as indicated by the reappearance and distribution of opaline silica in the sediments (Mikkelsen, this volume; Johnson, this volume). The inferred timing of this major late Miocene productivity change is consistent with evidence for the initiation of permanent upwelling conditions in the Arabian Sea, as preliminary data from ODP Leg 117 suggest (Prell, Niitsuma, et al., 1989). The sharp drop in MARs at about $3.5 \mathrm{Ma}$, however, is closely associated with clear evidence for intensive local winnowing, with late Pliocene and Pleistocene sediments at Site 707 largely consisting of loose foraminifer sands. At Site 237, a stratigraphically similar change in texture was again noted by Thiede (1974). The dramatic coarsening of the sediments at both shallow sites, in conjunction with the abrupt decrease in MARs at Site 707 , would seem to imply a further increase at about 3.5 $\mathrm{Ma}$ in the flow velocity of the intermediate waters that bathe the Northern Mascarene Plateau. Similar, and perhaps related, changes in bottom current velocities have been reported for the 


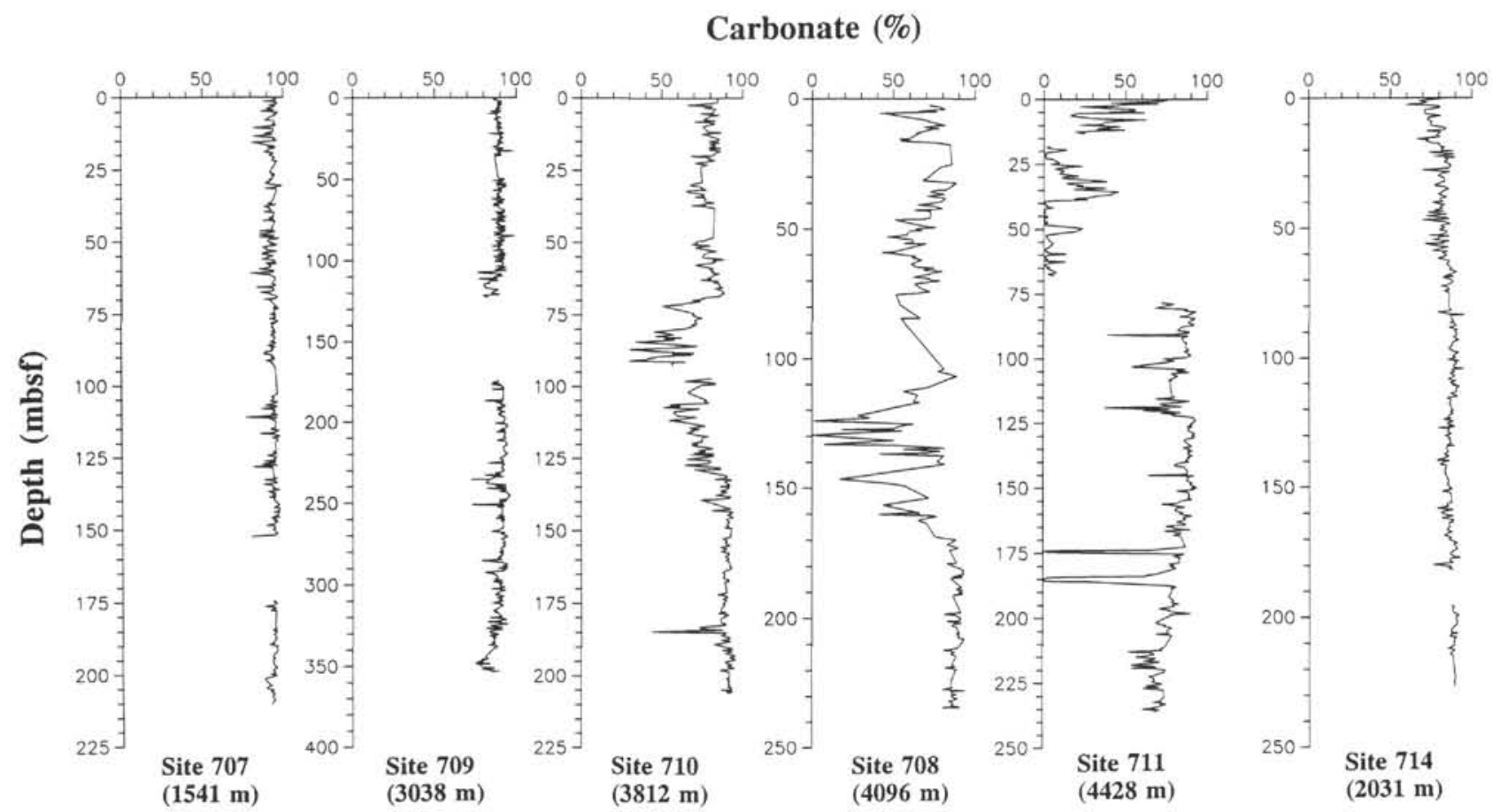

Figure 5. Variations in the measured carbonate content (wt \%) of sediments from transect Sites 707-711 and 714. The five transect records are arranged in order of increasing water depth from left to right in this figure with data plotted as a function of depth (meters below seafloor). Note that the depth scale is not constant between sites.

\section{Carbonate \%}

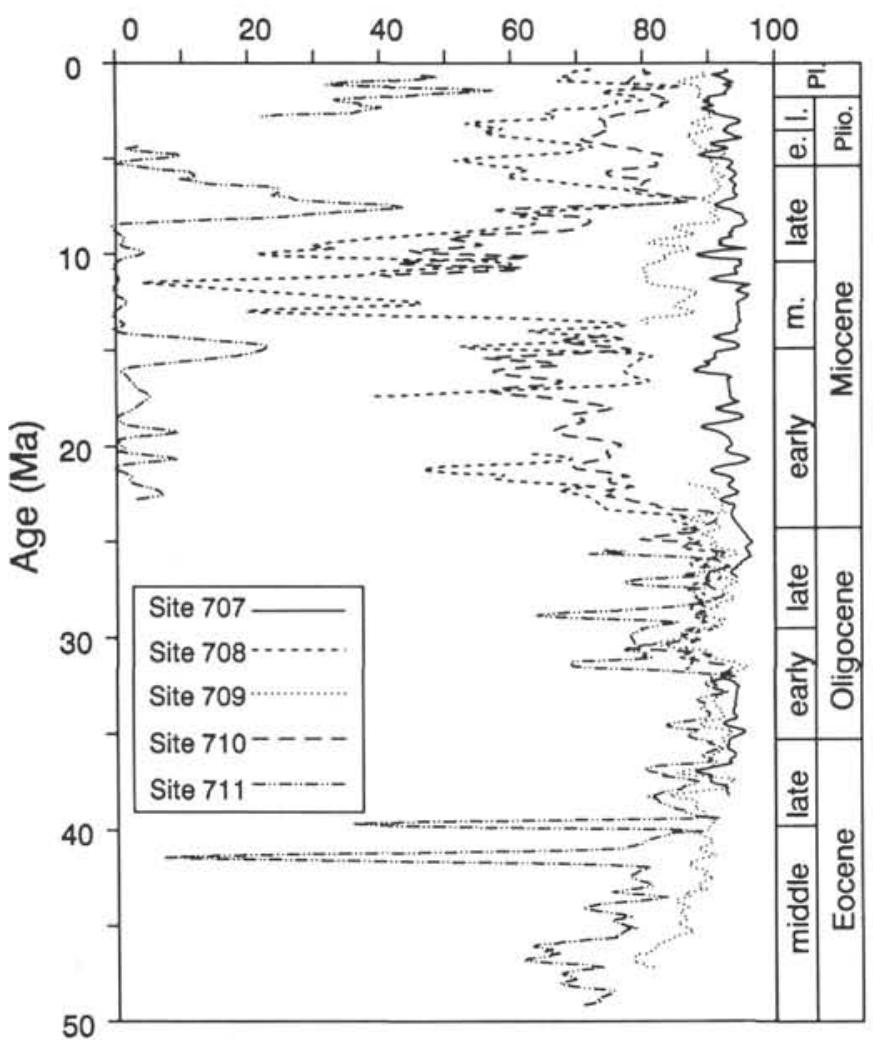

Figure 6. Carbonate data for the five transect sites plotted together as a function of estimated age. Data in this figure have been smoothed by means of a five-point running mean.
Southern Ocean and South Atlantic at this time (Fillon, 1972; Watkins and Kennett, 1972; Kennett and Watkins, 1976; Ledbetter et al., 1978).

\section{Hole 708 A}

The MAR curves for Hole 708A (Fig. 8) show two distinct intervals in which our reconstruction clearly suffers from core recovery problems and poor age control. In the first case, the dramatic drop in MAR values at the very top of the section (at $0.46 \mathrm{Ma}$ ) most likely results from nonrecovery of sediment from the sediment/water interface, which would invalidate our assumption of zero age for the top of the hole. The second interval where MAR estimates are probably questionable occurs between 20 and $25.2 \mathrm{Ma}$, a stretch of core for which our age control forced us to assume constant sedimentation rates despite a marked decrease in carbonate contents. Because other sites experienced a progressive upward decrease in bulk sedimentation rates in conjunction with a drop in carbonate across this interval, we presume that the rather high and constant bulk MARs shown in Figure 8 for Hole 708A are artificial and stem from an insufficiently resolved chronology. If true, then the drop in carbonate MARs that shows up between about 25 and 20 Ma was probably greater in reality than actually estimated, and the corresponding rise in noncarbonate MARs would be likewise exaggerated.

Late Paleogene bulk MARs at Site $708\left(\sim 0.6 \mathrm{~g} / \mathrm{cm}^{2} / 1000\right.$ yr) approximate those recorded at the much shallower Site 707, although the noncarbonate contribution to this total is slightly greater. Throughout the overlying Neogene section, the occurrence of scattered samples that are barren of carbonate suggests that the CCD occasionally shoaled for short periods above the paleodepth of this site. The major long-term change in the depth of the CCD, however, apparently occurred between about $22 \mathrm{Ma}$ and 8-9 Ma, as indicated by the poor preservation and very low carbonate MARs throughout this interval $(<0.1 \mathrm{~g} /$ 


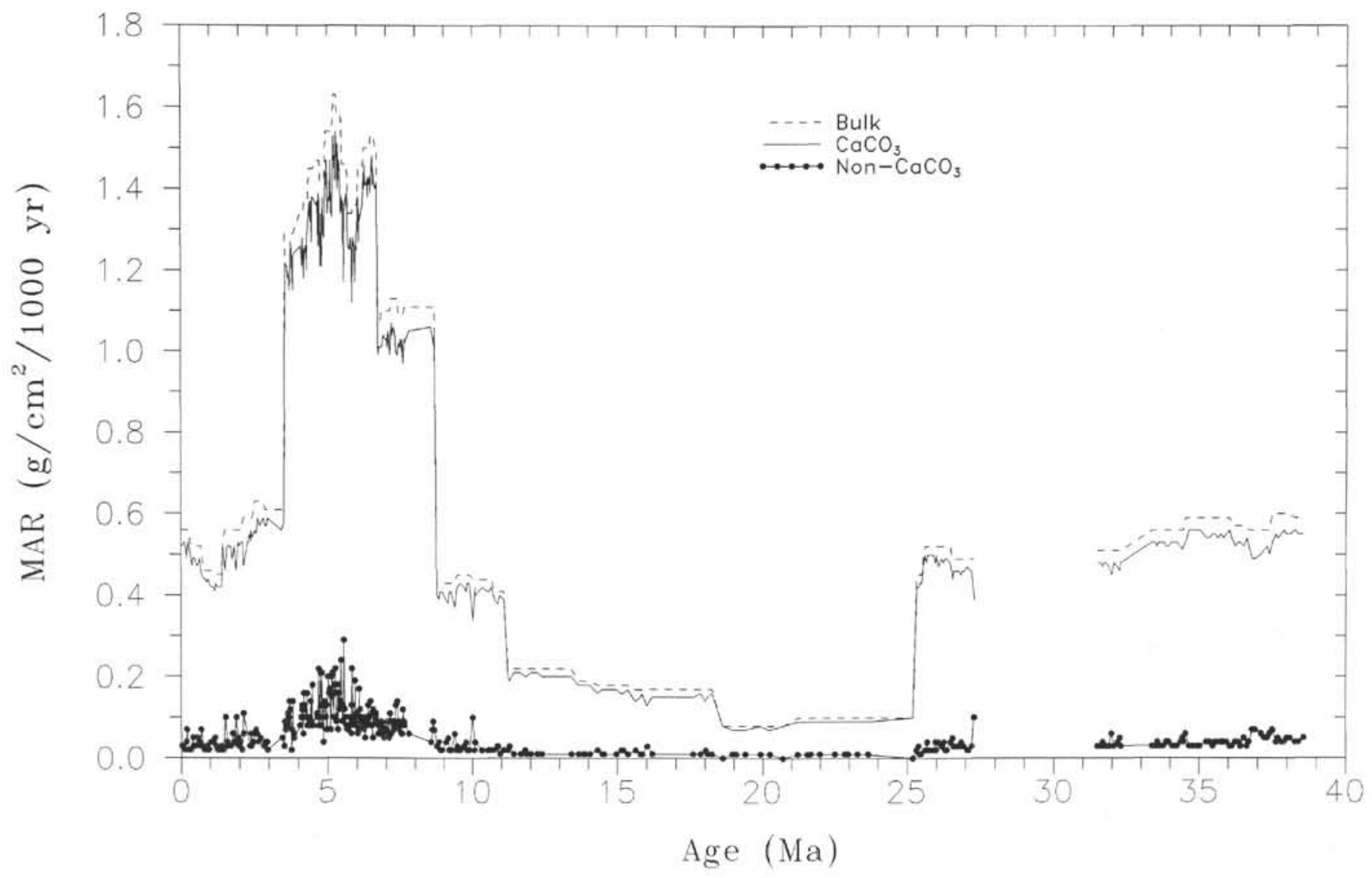

Figure 7. Calculated mass accumulation rates of bulk sediment and the biogenic carbonate and noncarbonate fractions at Site 707.

$\mathrm{cm}^{2} / 1000 \mathrm{yr}$ ). The transition in the earliest Miocene from a $\mathrm{Pa}$ leogene sedimentation regime with relatively high and constant carbonate MARs to this long interval ( $\sim 13 \mathrm{~m} . \mathrm{y}$.) of greatly reduced total accumulation occurred over less than 2 m.y., between about 24 and $22 \mathrm{Ma}$, according to our poorly constrained age model.

Bulk and carbonate MARs at Site 708 increase approximately threefold from early and middle Miocene values at about 8-9 Ma. In contrast to the surrounding time intervals, the interval between 2.65 and $3.56 \mathrm{Ma}$ is characterized by distinctly lower MARs. A datum event at $3.56 \mathrm{Ma}$, an event considered to be calibrated accurately to the geomagnetic polarity time scale, is responsible for the low bulk MARs in this interval $(\sim 0.4$ $\mathrm{g} / \mathrm{cm}^{2} / 1000 \mathrm{yr}$ ). The possibility of our having placed this extinction event too deep, however, cannot be excluded because of the alternating pelagic and turbidite deposition that characterize this site. Regardless of this, the change in relative proportions of carbonate and noncarbonate accumulation that occurs at about 2.6-2.7 Ma is interesting because its timing closely approximates the first appearance of large-scale glacial cycles in the Northern Hemisphere (Shackleton et al., 1984). The general increase in carbonate MARs from intermediate values (0.3-0.6 $\mathrm{g} / \mathrm{cm}^{2} / 1000 \mathrm{yr}$ ) in the late Miocene-early Pliocene to higher values $\left(0.7-1.1 \mathrm{~g} / \mathrm{cm}^{2} / 1000 \mathrm{yr}\right)$ in the late Pliocene-Pleistocene would seem to implicate enhanced carbonate preservation at this deep site as the causal mechanism.

\section{Holes $709 \mathrm{~A}$ and $709 \mathrm{C}$}

Carbonate accumulation consistently accounts for about $80 \%$ $90 \%$ of the record of bulk sediment accumulation at Site 709 (Fig. 9), the second shallowest site of the five-site transect. The
MAR curves in Figure 9 are a composite record, with data from Holes $709 \mathrm{~A}$ and $709 \mathrm{C}$ patched together at about the $25-\mathrm{Ma}$ level. The gap in data between about 14 and 21.7 Ma represents data discarded because of a disturbed interval, characterized by numerous stratigraphic inversions, in Hole 709A. Further details on the stratigraphy of this site can be found in Appendix B.

Below the data gap in Figure 9, the record indicates that sediment accumulation at Site 709 in the earliest Miocene and Paleogene was fairly uniform. Assuming our Paleogene age model is in order, there appears to be little evidence for significant changes in pelagic input, suggesting long-term stability in the nutrient supply to the surface ocean. Higher frequency variability in the carbonate MARs is clearly evident, though the origins are as yet poorly understood. The fairly constant record of noncarbonate accumulation suggests that dilution has not been an important variable in the equation, although some of the singlesample peaks clearly result from the sampling of volcanic ash layers that are common throughout the Paleogene sequence.

Data from Hole 709A around the Miocene/Oligocene boundary should be viewed with caution because of the substantial uncertainties associated with our poorly constrained age model between 21.7 and $25.5 \mathrm{Ma}$. The fact that Figure 9 does not show a pronounced drop in either bulk or carbonate MARs as in other transect sites during this interval implies that our age control in Hole 709A is not without problems. Low MARs $\left(<0.3 \mathrm{~g} / \mathrm{cm}^{2} /\right.$ $1000 \mathrm{yr}$ ) observed between 14 and $9 \mathrm{Ma}$, however, are consistent with those observed at Sites 707 and 708 . Calcareous microfossil preservation in Hole 709A indicates significant dissolution during this interval, with planktonic foraminifers found to be poorly preserved and calcareous nannofossil assemblages enriched in dissolution-resistant species. 


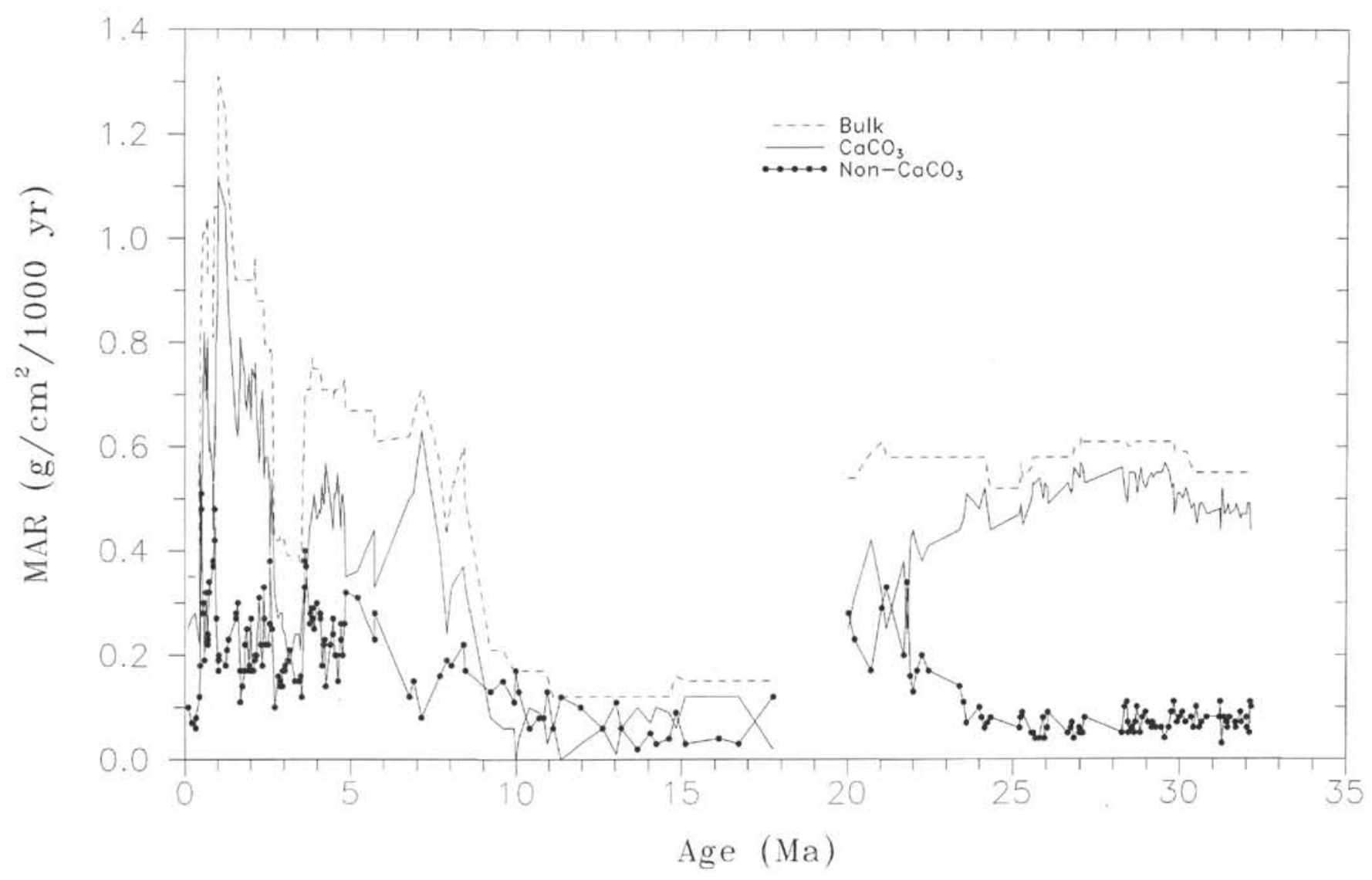

Figure 8. Calculated mass accumulation rates of bulk sediment and the biogenic carbonate and noncarbonate fractions at Site 708.

As at the previous two sites, the most prominent features of the Site 709 accumulation record are the high MAR values recorded for the late Miocene and early Pliocene $\left(1.0-1.7 \mathrm{~g} / \mathrm{cm}^{2} /\right.$ $1000 \mathrm{yr}$ ), with the major MAR transitions here found to occur at 8.7, 6.7, and 3.4 Ma. Although preservation of foraminifers at Site 709 generally deteriorates downhole through this interval (Backman, Duncan, et al., 1988), it seems unlikely that changes in carbonate preservation alone can explain the magnitude of the MAR changes observed over the last $12 \mathrm{~m}$.y. of continuous record. Diatoms are common in sediments younger than $3.4 \mathrm{Ma}$ and can be found in minor abundance in sediments as old as 7 $\mathrm{Ma}$, whereas radiolarians and sponge spicules are common back to about $8 \mathrm{Ma}$ (Mikkelsen, this volume; Johnson, this volume). The distribution of preserved silica, together with the observation that carbonate and noncarbonate MARs tend to parallel each other throughout this interval, would seem to implicate changes in pelagic flux as having the dominant control over MAR variations at this site since the late Miocene.

\section{Hole 710 A}

Data on MARs derived from the study of Hole 710A sediments are presented in Figure 10. Site 710, at a modern water depth of $3812 \mathrm{~m}$, is located some $30 \mathrm{~nm}$ to the south-southeast of Site 709 and some $800 \mathrm{~m}$ deeper. Because both sites were drilled on the same physiographic feature, their vertical separation is likely to have remained more or less the same through time (see "Discussion" section, this chapter). Between $25 \mathrm{Ma}$ and the end of the record at $33 \mathrm{Ma}$, the average bulk and carbonate MARs for Site 710 slightly exceed the comparable average calculated for the shallower Site 709 (e.g., carbonate MARs: Site $710=0.72 \mathrm{~g} / \mathrm{cm}^{2} / 1000 \mathrm{yr}$; Site $709=0.67 \mathrm{~g} / \mathrm{cm}^{2} / 1000$ yr). Though the mean values are close, careful inspection of the two MAR records (Figs. 9 and 10) indicates discrete intervals where accumulation rates are clearly higher at Site 710 . Although difficult to determine how meaningful such differences are, they illustrate the very real problem of assessing the effects of winnowing and downslope transport on MAR data collected in the context of a depth transect.

The transition seen in other sites from the higher bulk MARs of the Paleogene to the low MARs of the early Neogene is clearly recorded at Site 710 . The fairly constant accumulation of noncarbonate (typically $<0.1 \mathrm{~g} / \mathrm{cm}^{2} / 1000 \mathrm{yr}$ ) throughout the early Miocene-Oligocene interval (17-33 Ma) indicates that dilution is not a factor in this change of sedimentation regime (the short, sharp drop in carbonate MAR at $30.6 \mathrm{Ma}$ is caused by an ash layer). Rather, the approximately fourfold decrease in carbonate accumulation (from $>0.7$ to $<0.2 \mathrm{~g} / \mathrm{cm}^{2} / 1000 \mathrm{yr}$ ) that drives the change in bulk accumulation must arise from some combination of increased dissolution and/or reduced productivity near the Oligocene/Miocene boundary. Planktonic foraminifers are severely dissolved in the early and middle Miocene interval, whereas nannofossil assemblages exhibit significant etching, low species diversity, and a high relative abundance of discoasterids (Rio et al., this volume). These observations, together with the disappearance of biogenic silica from sediments near the top of the Oligocene section, are consistent with some combination of these two mechanisms. Although the transition appears steplike in Figure 10, spanning an interval between 25 and $21 \mathrm{Ma}$, the true nature of sedimentation changes across this boundary is difficult to evaluate given that we lose magnetostratigraphic control of our age model at $22.35 \mathrm{Ma}$ and revert to purely biostratigraphic control below. 


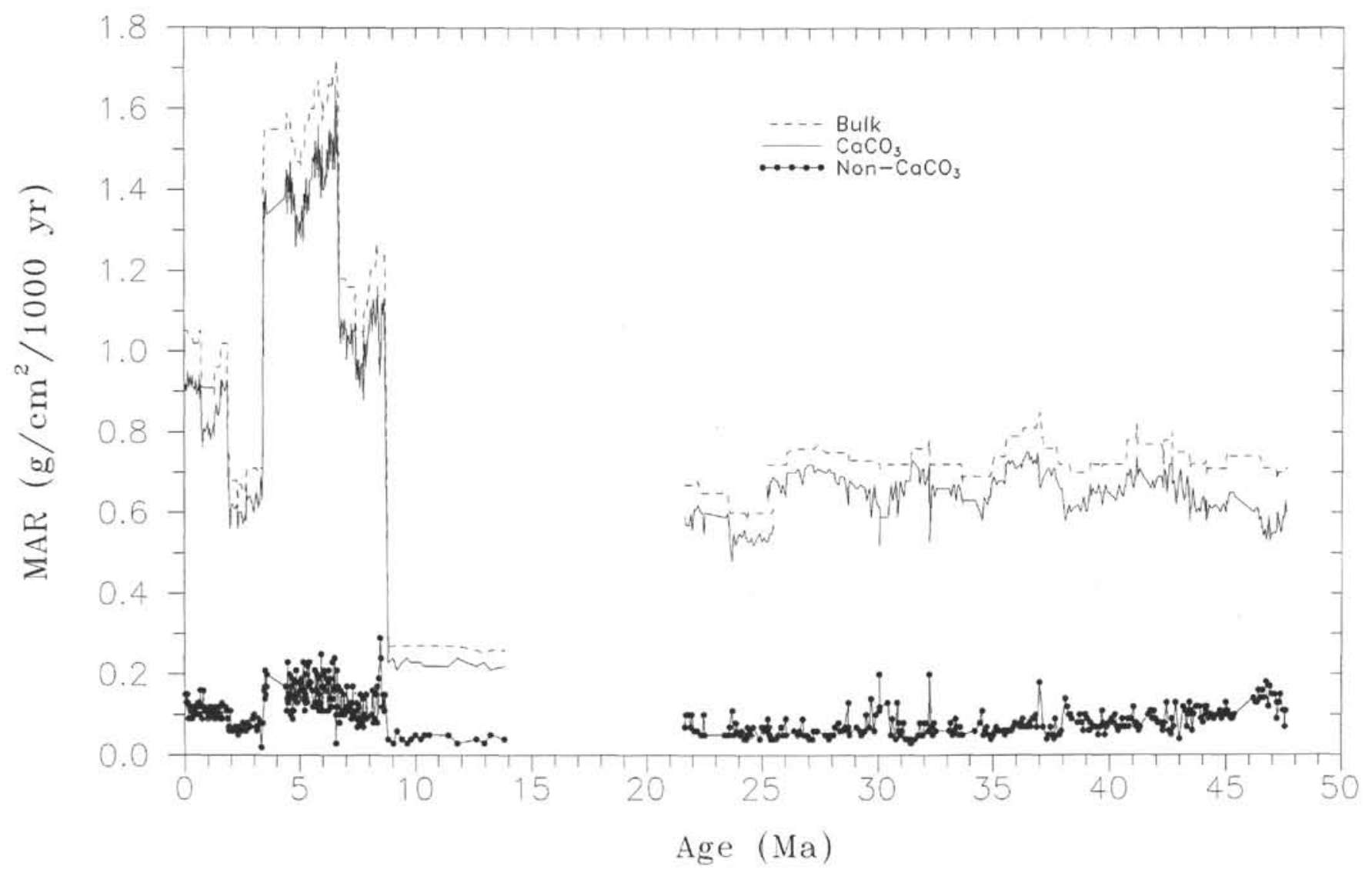

Figure 9. Calculated mass accumulation rates of bulk sediment and the biogenic carbonate and noncarbonate fractions at Site 709.

Between two reversal boundaries at 21.16 and $16.22 \mathrm{Ma}$, our assumption of a linear sedimentation rate results in constant bulk MARs. The reduced variability in both the carbonate and noncarbonate MARs here is likely to be, in part, an artifact of the increased temporal sampling interval that results from the low sedimentation rate in this interval, the lowest rate recorded at Site 710. Nannofossils indicate a coherent stratigraphy in the interval above, although we consider it likely that the high MAR values between 16 and $14 \mathrm{Ma}\left(\sim 0.4-0.8 \mathrm{~g} / \mathrm{cm}^{2} / 1000 \mathrm{yr}\right)$ are artificially elevated by reworked materials. In the time interval between about 14 and $11.6 \mathrm{Ma}$, data were discarded because of clear evidence that this portion of the sequence was slumped. The low accumulation rates and poor preservation of carbonate between about 11.6 and $8 \mathrm{Ma}$ implies that Site 710 was located close to the depth of the CCD at this time.

The sharp rise in carbonate MARs observed in other sites during the early late Miocene is also observed at Site 710, although the greater part of the rise appears to occur about $1 \mathrm{~m} . \mathrm{y}$. later (7.5-8 Ma) than recorded at Sites 707 and 709 (8.5-9 Ma). The magnitude of this discrepancy can be more precisely determined by focusing on a distinct dissolution event that is found in the records of both Sites 709 and 710 . This event shows up most clearly as peaks in the noncarbonate MARs and is located in both records at the base of the major early late Miocene rise in carbonate and bulk accumulation. An age of $7.7 \mathrm{Ma}$ is assigned to this event at Site 710 (Fig. 10) and one of $8.5 \mathrm{Ma}$ at Site 709 (Fig. 9), yielding a difference of $0.8 \mathrm{~m}$.y. for what is presumably a synchronous event. If the latter assumption is true, an imperfection in our age models is implied. Given that age control in the pertinent interval is based on magnetostratigraphy in Site 710 and biostratigraphy in Sites 707 and 709, one would tend to expect that the data from Site 710 provide a more accurate chronology for this event.

The average late Neogene ( $0-8 \mathrm{Ma})$ accumulation rate for the noncarbonate sediment fraction at Site $710\left(0.18 \mathrm{~g} / \mathrm{cm}^{2} / 1000\right.$ yr) slightly exceeds that found at the shallower Site $709(0.13$ $\left.\mathrm{g} / \mathrm{cm}^{2} / 1000 \mathrm{yr}\right)$. Although the implication of having some excess noncarbonate at Site 710 is that excess carbonate may be there as well, the average late Neogene carbonate MAR of this site is still substantially lower than at Site $709(0.68$ and $1.11 \mathrm{~g} /$ $\mathrm{cm}^{2} / 1000 \mathrm{yr}$, respectively). Therefore, on average, some $40 \%$, if not more, of the deposited carbonate has been lost from the sediments at the deeper Site 710 over this interval.

\section{Hole 711 A}

As the deep end-member of the depth transect, Site 711 should have been most heavily influenced by carbonate dissolution. As Figures 6 and 11 indicate, this has clearly been the case. For most of the Neogene, carbonate accumulation has represented only a small fraction of the bulk accumulation at this site, indicating a position consistently close to or below the CCD. This contrasts sharply with the Paleogene, where carbonate accumulation generally accounts for $80 \%-90 \%$ of the total deposition.

Site 711 records the greatest variability in accumulation of all the transect sites during the Paleogene. The highest bulk and carbonate MARs observed at this site $\left(>0.4 \mathrm{~g} / \mathrm{cm}^{2} / 1000 \mathrm{yr}\right)$ are encountered in the Oligocene through late Eocene interval. Sediments of this age consist predominantly of clay-bearing nannofossil oozes, with planktonic and benthic foraminifers usually absent or poorly preserved where present in minor numbers. Carbonate MARs are generally lower in the middle Eocene in- 


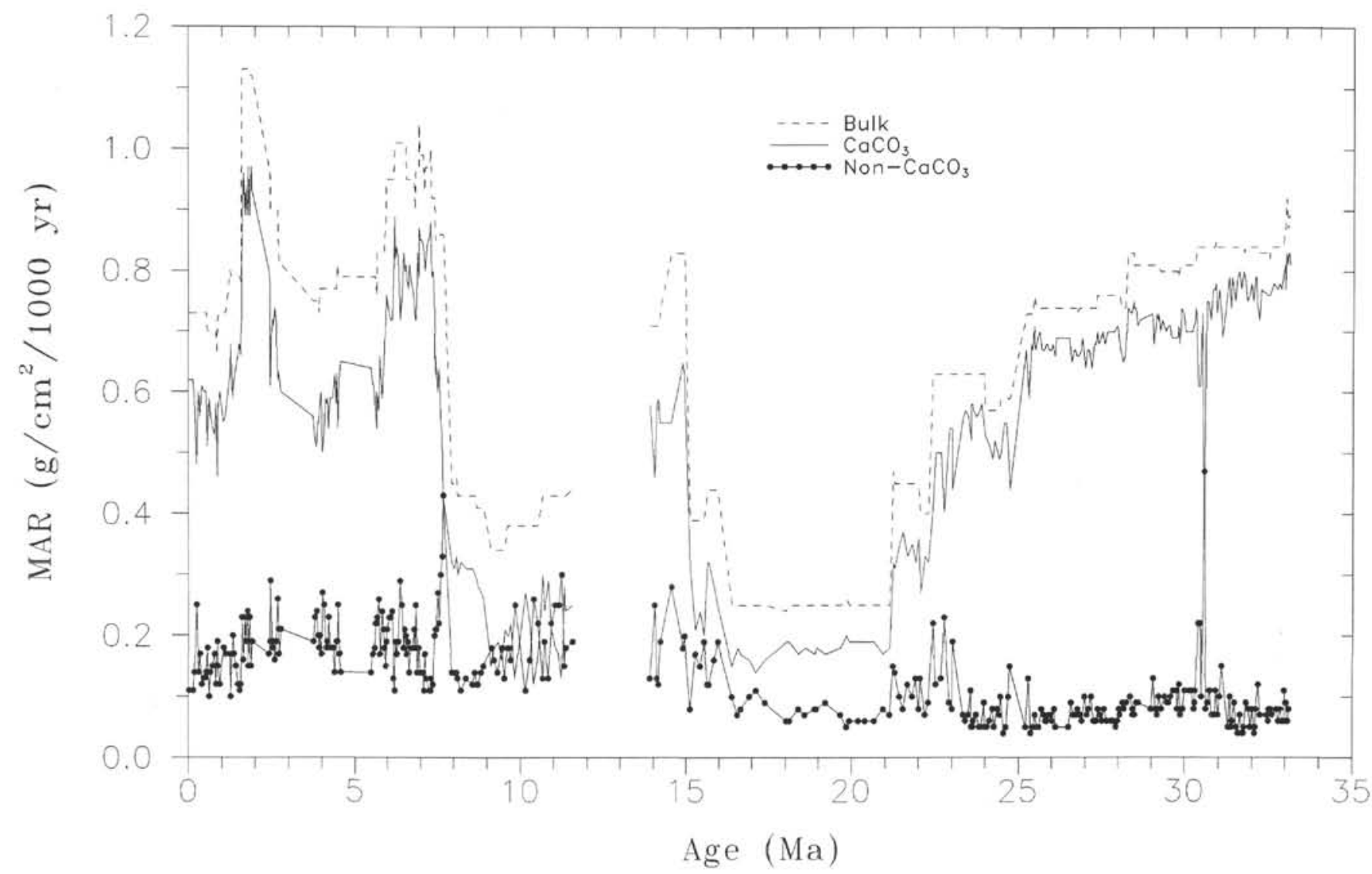

Figure 10. Calculated mass accumulation rates of bulk sediment and the biogenic carbonate and noncarbonate fractions at Site 710 .

terval $\left(0.2-0.4 \mathrm{~g} / \mathrm{cm}^{2} / 1000 \mathrm{yr}\right)$, with the lowest rates found near the middle/late Eocene boundary. Radiolarians are common in sediments throughout this interval. Although reworking is fairly common in the Paleogene sequence (Backman, Duncan, et al., 1988; Premoli Silva and Spezzaferri, this volume), nearly all nannofossil zones and subzones could be recognized and datum events were found to occur in a manner similar to what was observed at all of the other sites (Okada, this volume).

The subdued carbonate MARs in the middle Eocene, and particularly those spanning the middle/late Eocene boundary, can probably be attributed to dissolution because the long record from Site 709 (Fig. 9) shows no comparable MAR reduction at this time. The two sharp drops in carbonate accumulation at Site 711 that bracket $40 \mathrm{Ma}$ are balanced by two peaks in noncarbonate accumulation (Fig. 11). Sediments in these distinct intervals (39.55-39.75 Ma and 41.2-41.5 Ma) consist of almost pure radiolarian oozes. Although the possibility exists that they represent two brief episodes where conditions were suitable for radiolarian blooms, we think it more likely that the nearly pure nature of these layers is the result of intense carbonate dissolution and the resulting concentration of the opaline radiolarians. The changes in carbonate $\mathrm{wt} \%$ and MAR are easily explained this way, but the probable explanation for the accompanying rise in noncarbonate MARs is more subtle. Theoretically, the noncarbonate MARs should show no increase if the silica has been chemically concentrated, rather than increased through a change in radiolarian flux. However, as discussed earlier, we do not entirely escape from the "closed-sum" problem when using data constrained by an age model insufficient to resolve the true duration of short events. Because the noncarbonate MAR is determined by subtracting the calculated carbonate MAR from the bulk MAR, a sharp dissolution-related drop in the carbonate mass flux over an interval where the sedimentation rate is assumed constant will produce an artificially inflated noncarbonate MAR peak. We suspect that such is the case here, particularly since correlative radiolarian-rich layers were not identified at Site 709. Our inference of increased dissolution at Site 711 at this time is supported by observations of Okada (this volume) of greatly reduced diversity in the calcareous nannofossil assemblages at this site relative to Site 709 near the early/late Eocene boundary.

In the Oligocene, another short episode of significantly reduced carbonate MARs $\left(\sim 0.3 \mathrm{~g} / \mathrm{cm}^{2} / 1000 \mathrm{yr}\right)$ occurs at an interpolated age between 30.6 and $31.6 \mathrm{Ma}$. Although our lack of oxygen isotope data precludes a firm correlation at this time, this event, chronologically, would seem to correspond both with a brief episode of glacial build-up (Shackleton, 1986; Miller et al., 1987) and a glacioeustatic sea-level drop of 30-90 m (Miller et al., 1987). Haq et al. (1987) show this sea-level fall near the Rupelian/Chattian boundary at over $100 \mathrm{~m}$ and contend that it was the largest single drop since the Jurassic. Most ideas of how sea level and carbonate accumulation are linked hold to the notion that low sea-level stands are associated with enhanced carbonate accumulation and suppressed CCDs in open-ocean environments (e.g., Berger and Winterer, 1974; Hay and Southam, 1977). At first glance, this view would appear to conflict with the reduction in carbonate MARs recorded at Site 711. Further inspection of the raw data and visual core descriptions, however, reveals that the pronounced low centered on about $31 \mathrm{Ma}$ falls within a disseminated ash layer. Although ash dilution may help explain the short, sharp carbonate MAR minimum, the broader trough in the carbonate MAR record between about 29 and 32.5 


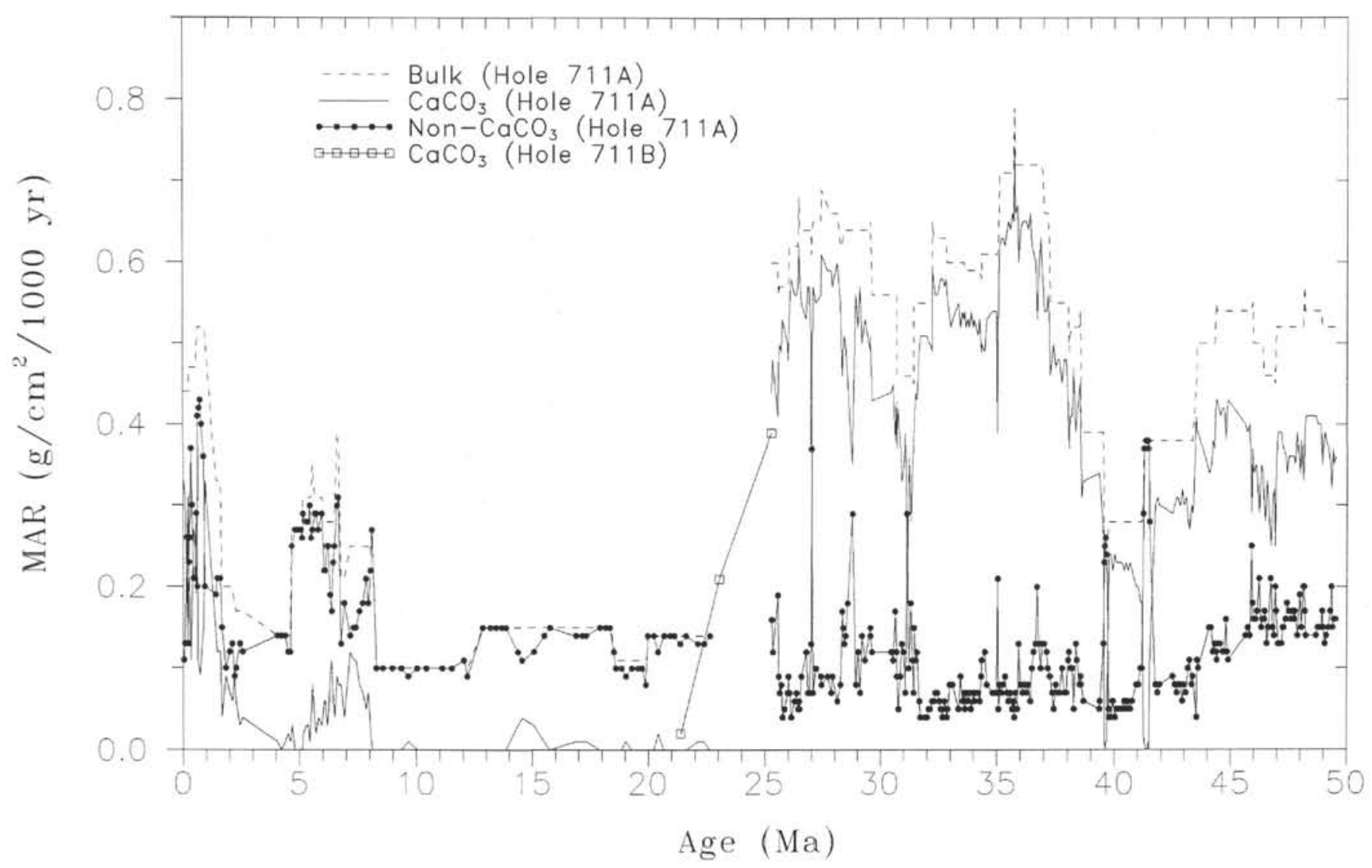

Figure 11. Calculated mass accumulation rates of bulk sediment and the biogenic carbonate and noncarbonate fractions at Site 711. Data from Hole 711B are included in this figure between 22 and $25 \mathrm{Ma}$ to bridge the data gap caused by a core recovery problem in Hole $711 \mathrm{~A}$.

Ma may in fact be real. For example, a similar, though less prominent, low in carbonate MAR is observed at Site 709 (Fig. 9). As noted above, such a decrease, if real, would appear to be inconsistent with the expected consequences of a major sea-level fall. Even if the pattern is backward, however, it is perhaps most surprising that a sea-level change of this magnitude seems to have had such a small net effect on the accumulation history of this suite of sites. The apparent lack of a response of the CCD to the Rupelian/Chattian sea-level fall has been previously noted by Rea and Leinen (1985) at DSDP sites in the South Pacific.

A core recovery problem in Hole 711A resulted in data loss over the critical Oligocene/Miocene boundary interval (22.64$25.30 \mathrm{Ma}$ ). Fortunately, this interval was cored without incident in Hole 711B. The recovered sequence represents the only section among the transect sites that contains a continuous, magnetostratigraphically constrained record through that entire interval. In Figure 11, we include carbonate MARs for three samples from Hole 711B for which dry-bulk density and carbonate measurements are available. The results would seem to indicate that the complete transition from high Paleogene MARs to low Neogene MARs occurred over approximately $3 \mathrm{~m}$.y., between 25.3 $\mathrm{Ma}$ and about $22.6 \mathrm{Ma}$.

Only a small number of samples in the early through middle Miocene sequence at Site 711 record measurable carbonate accumulation. Sediments here are virtually devoid of planktonic foraminifers, and calcareous nannofossils, where present in unreworked assemblages, are mainly represented by dissolution-resistant species. A slight rise in carbonate MAR centered on 15 $\mathrm{Ma}\left(\sim 0.04 \mathrm{~g} / \mathrm{cm}^{2} / 1000 \mathrm{yr}\right)$ appears to correlate in time with the accumulation peak already noted in the Hole $710 \mathrm{~A}$ record (Fig. 10).

The late Miocene peak in accumulation rates observed at all shallower transect sites is also recorded at Site 711, although the magnitude is much reduced. The sharp rise in MARs above the low background rates that characterize early and middle Miocene sediments begins here between 8.04 and $7.95 \mathrm{Ma}$. At Site 710 , a magnetostratigraphically constrained change in sedimentation rate is inferred at $7.90 \mathrm{Ma}$, although a $0.26-\mathrm{m}$.y. gap in our carbonate sampling (7.68-7.94 Ma) tends to push our estimate for the MAR rise toward the younger side of that sampling gap. From this, we conclude that the true inception of the late Miocene rise in MARs cannot be very much younger than 7.90 $\mathrm{Ma}$ and certainly no older than $8.04 \mathrm{Ma}$, implying that the transition seems to have occurred over no more than about $0.3 \mathrm{~m}$.y. The rather close agreement of the two estimates from the magnetically constrained Sites 710 and 711 again points to the likelihood of an age-model problem between 8 and $9 \mathrm{Ma}$ in Sites 707 through 709 , presumably biochronological in nature, that places the age of this transition about $1 \mathrm{~m}$.y. earlier in the latter sites.

Carbonate accumulation between 0 and $2.56 \mathrm{Ma}$ never exceeds $0.33 \mathrm{~g} / \mathrm{cm}^{2} / 1000 \mathrm{yr}$, but nonetheless shows a steady increase from $2.56 \mathrm{Ma}$ to present values. Core recovery problems resulted in loss of data between 2.56 and 4.07 Ma in Hole 711A; however, a limited number of shipboard measurements of carbonate content and dry-bulk density from Hole 711B suggest that virtually no carbonate $\left(<0.02 \mathrm{~g} / \mathrm{cm}^{2} / 1000 \mathrm{yr}\right)$ accumulated at Site 711 during this interval. The late Pliocene rise in carbonate MARs that postdates this nearly barren zone appears to begin 


\section{C. PETERSON, J. BACKMAN}

somewhere about $2.5 \mathrm{Ma}$, an age estimate that closely coincides with the inferred onset of large-scale Northern Hemisphere glaciation (Shackleton et al., 1984). Though the mechanism is not clear, there would appear to be a strong and suggestive time correlation between Northern Hemisphere climate deterioration and the development of conditions favorable to carbonate preservation in the deep tropical Indian Ocean (see also Curry et al., this volume).

\section{Hole $714 A$}

Because of the nearly 7-m.y. hiatus near the top of the record, the MAR data from Hole 714A (Fig. 12) only provide useful information for the interval spanning the early late Miocene through latest Oligocene. Even a casual examination of the data in Figure 12 indicates that accumulation patterns at Site 714 in the Maldives are strikingly different from those observed at the other transect sites, presently some $1000 \mathrm{nmi}$ to the southwest. Accumulation rates at this shallow site for both the carbonate $\left(\sim 0.4 \mathrm{~g} / \mathrm{cm}^{2} / 1000 \mathrm{yr}\right)$ and noncarbonate $\left(\sim 0.1 \mathrm{~g} / \mathrm{cm}^{2} / 1000 \mathrm{yr}\right)$ fractions are comparable with those at Sites 707-711 in the late Oligocene and earliest Miocene, but then show an abrupt rise between 18 and $19 \mathrm{Ma}$ in a pattern both opposite and differing in timing from what was observed on and near the Mascarene Plateau. Carbonate and bulk accumulation rates reach values of $1.2-1.6 \mathrm{~g} / \mathrm{cm}^{2} / 1000 \mathrm{yr}$ before dropping slightly at $13.6 \mathrm{Ma}$, and then show no further change before the hiatus is reached.

As compared to what is observed for the five transect sites, the generally much higher Miocene accumulation rates at Site 714 must indicate a very different set of nutrient conditions in the surface waters, perhaps related to the site's proximity to the Indian subcontinent and to its migration across the equator aboard the Indo-Australian Plate relative to the more fixed locations of the other sites to the south. Despite the absolute differ- ence in the average accumulation rates, the interval of increased carbonate accumulation between about 13 and $18 \mathrm{Ma}$ at Site 714 can perhaps be related to the slight rise in carbonate MARs observed at Sites 710 and 711 at about 14-16 Ma, although questions about the quality of the latter estimates exist (see further comments in the "Discussion" section, this chapter). Perhaps the greatest puzzle, however, is simply the observation that the accumulation record at Site 714 shows no evidence of the dramatic reduction in MARs seen at the other sites across the Oligocene/Miocene boundary (the data gap between 22.25 and 24.84 Ma in Figure 12 is a result of poor core recovery). At this time we have no explanation for this seemingly major discrepancy.

\section{DISCUSSION}

To help the intersite comparisons of carbonate accumulation, we have plotted the Eocene to Holocene carbonate MAR data for all transect sites except Site 708 together in Figure 13. In addition, an expanded view of late Neogene (0-12 Ma) accumulation patterns at all five sites is shown in Figure 14. To simplify their presentation, the carbonate MAR data in each of the two plots have been smoothed slightly using a five-point running mean.

In looking at the cumulative carbonate MAR data set, it is clear that three major periods characterized by distinct depthdependent accumulation patterns can be recognized in the western equatorial Indian Ocean: (1) the Paleogene, a time of intermediate carbonate accumulation rates $\left(0.4-0.7 \mathrm{~g} / \mathrm{cm}^{2} / 1000 \mathrm{yr}\right)$ and reduced between-site accumulation differences; (2) the early and middle Miocene, a period characterized by greatly reduced carbonate MARs (typically $<0.2 \mathrm{~g} / \mathrm{cm}^{2} / 1000 \mathrm{yr}$ ) at all of the sites; and (3) the late Miocene to Holocene, a span of time marked by the highest accumulation rates observed (up to 1.5

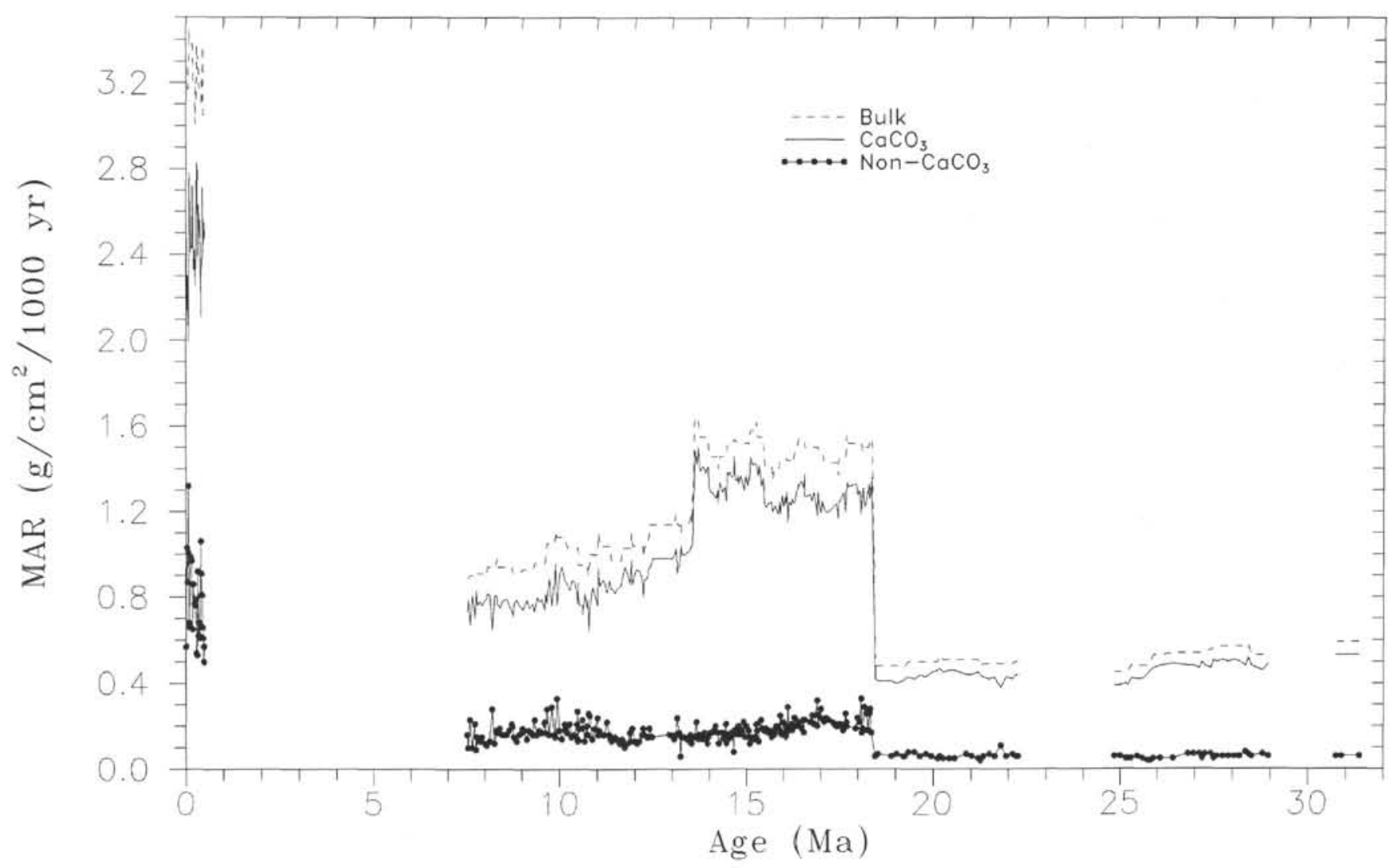

Figure 12. Calculated mass accumulation rates of bulk sediment and the biogenic carbonate and noncarbonate fractions at Site 714 . 


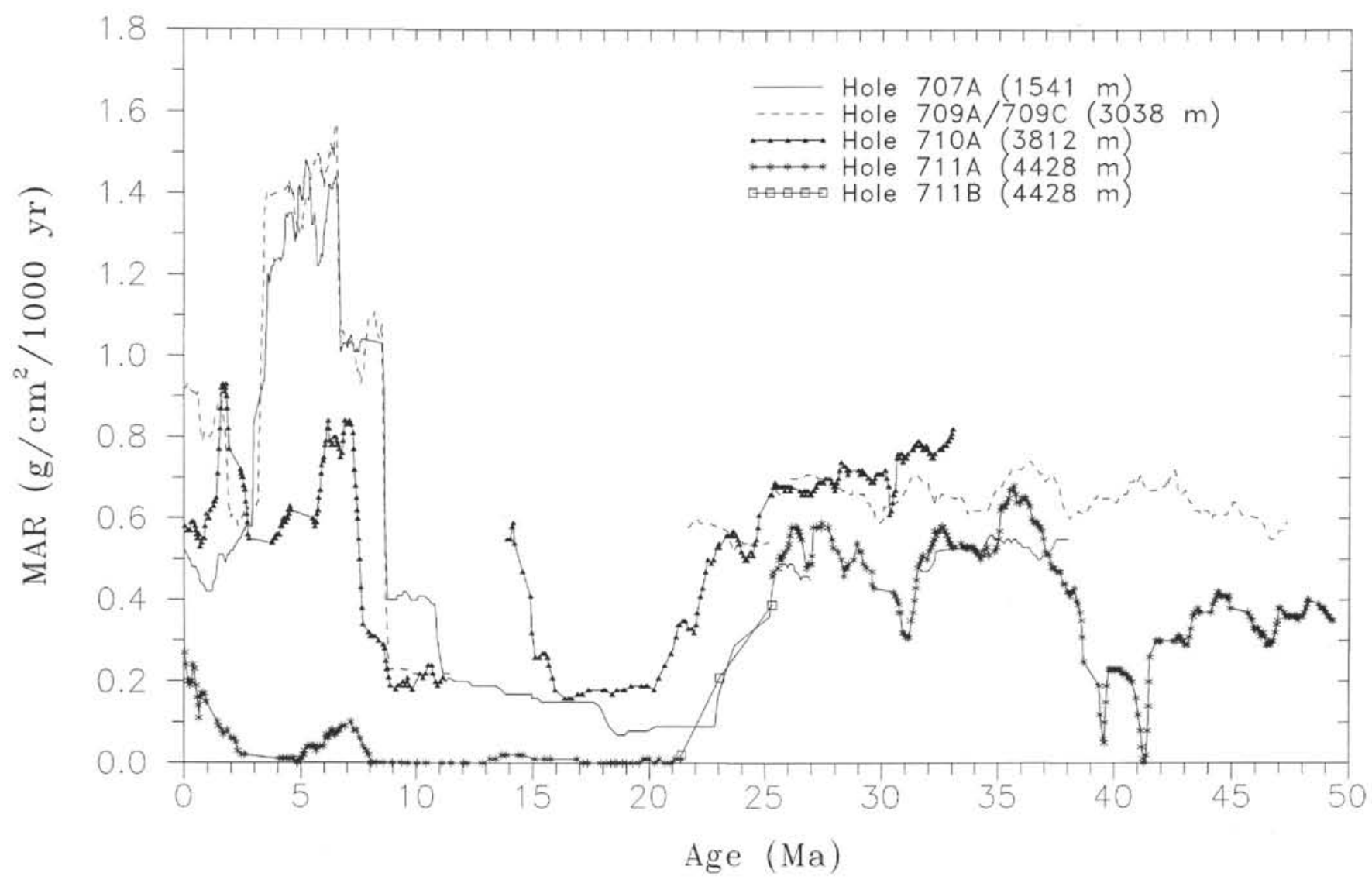

Figure 13. Combined carbonate accumulation histories for Sites 707, 709, 710, and 711. The data used in this figure have been smoothed by means of a five-point running average.

$\mathrm{g} / \mathrm{cm}^{2} / 1000 \mathrm{yr}$ ), and by the first sustained appearance of substantial contrasts in carbonate accumulation as a function of the water depth of the drill site.

Within the Paleogene, our knowledge of Eocene carbonate MARs comes mostly from the two long records of Sites 709 and 711 (Fig. 13). The Eocene record of Site 709 gives the impression of relatively uniform carbonate accumulation, with some higher frequency variability but little evidence for major changes in carbonate input or dissolution. In contrast to this, carbonate MARs at the deeper Site 711 drop to near zero over two short intervals centered near $40 \mathrm{Ma}$, and are significantly reduced relative to the comparatively stable rates in Site 709 over a broad surrounding interval. As noted earlier, sedimentary evidence supports our interpretation that dissolution is responsible for the low carbonate MARs at Site 711 at this time.

One of the most dramatic climatic steps of the Cenozoic occurred near the Eocene/Oligocene boundary (see Corliss et al., 1984, and Corliss and Keigwin, 1986, for reviews). At this time, distinct changes in the stable isotopic record of foraminifers and in biotic patterns occurred that have been interpreted as evidence for global cooling and the development of psychrospheric conditions in the deep ocean (e.g., Shackleton and Kennett, 1975; Benson, 1975; Haq, 1981; Keigwin, 1980; Shackleton, 1986). Coincident with this event, a pronounced drop in the depth of the CCD in all of the oceans (Heath, 1969; Berger, 1973; van Andel, 1975; Hay, 1988) has been attributed to the resulting changes in the character and turnover of oceanic bottom waters.

The steady increase in carbonate MARs at Site 711 between about 39 and $35 \mathrm{Ma}$ is presumably related to this well-docu- mented deepening of the CCD. Although records from the $\mathrm{Pa}$ cific indicate an abrupt drop of the CCD across the Eocene/Oligocene boundary (Berger, 1973; van Andel, 1975), the reconstruction of van Andel (1975) shows the CCD to have dropped much more gradually across this boundary in the Indian and Atlantic Oceans. Although the rise in carbonate MARs at Site 711 is consistent with a gradual fall of the CCD, it is interesting to note that the accumulation record of the shallower Site 709 gives no indication of related changes in surface productivity. This is perhaps surprising given that Thunell and Corliss (1986) previously reported an increase in carbonate accumulation rates across the Eocene/Oligocene boundary at Indian Ocean DSDP Sites 214 and 219 , a rise that they attributed to higher carbonate input from the surface. Whether this discrepancy is somehow an artifact of the use of different age models or indicates real intrabasinal differences requires further evaluation.

Throughout most of the Oligocene, accumulation rate changes can be traced reasonably well across the four sites shown in Figure 13. On average, carbonate MARs in the Oligocene vary by only about $0.2-0.3 \mathrm{~g} / \mathrm{cm}^{2} / 1000 \mathrm{yr}$ among the sites, an observation that indicates that the accumulation gradient between sites was considerably reduced relative to the gradient around $40 \mathrm{Ma}$, or to what is observed for the late Neogene. These differences in gradient are well illustrated in Figure 15, in which we have expressed the depth-dependent changes in carbonate accumulation at Sites 710 and 711 relative to accumulation at Site 709. By using Site 709 as a base line for the shallow accumulation pattern, we see that carbonate accumulation during the Oligocene at Site 711 is typically about $25 \%$ lower than at Site 709 , implying that only about a quarter of the carbonate input is lost over 


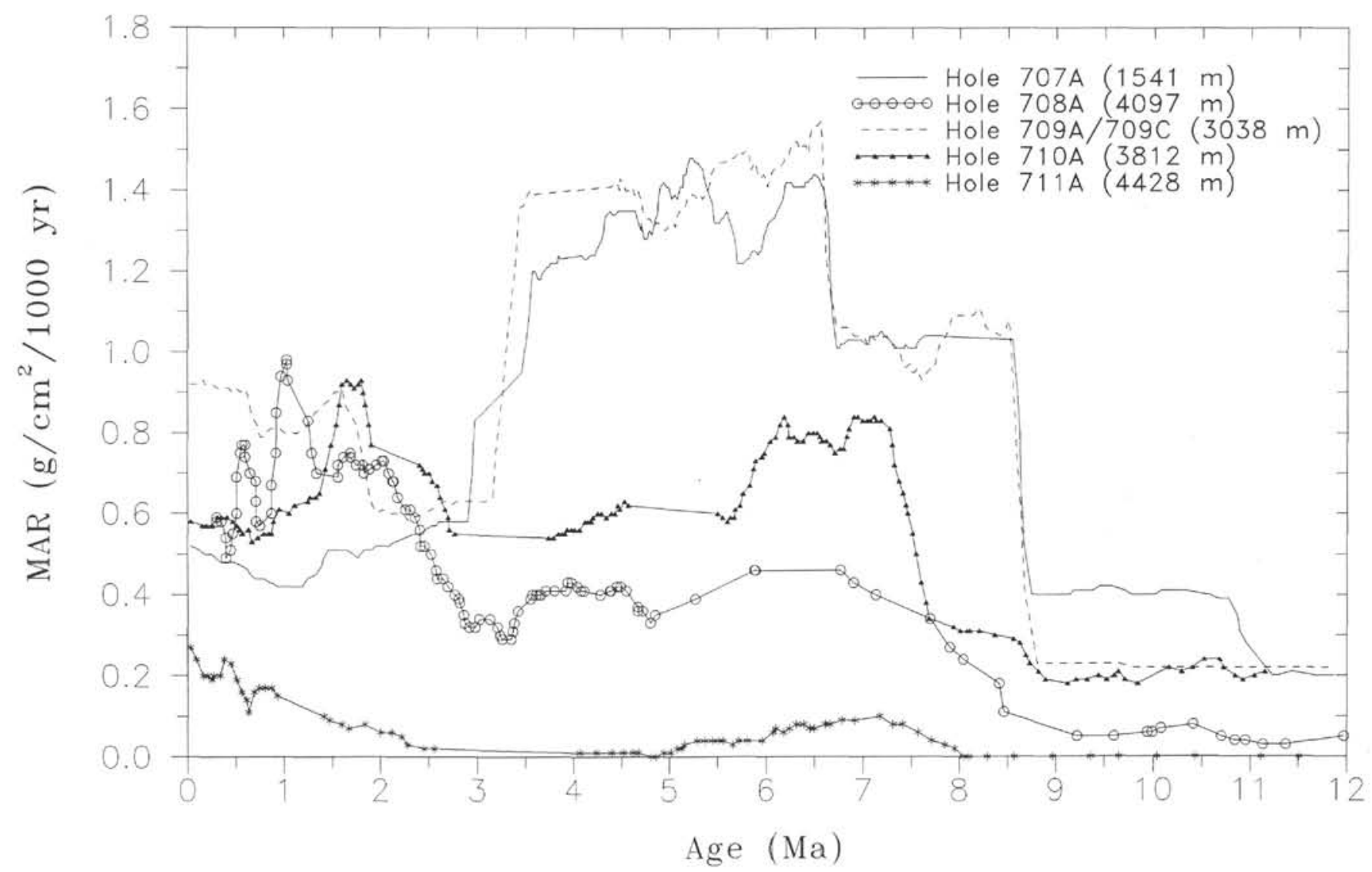

Figure 14. Detailed view of late Neogene (0-12 Ma) carbonate accumulation histories for transect Sites 707 through 711.

the $1400 \mathrm{~m}$ or so that separate these two sites. If our assumption of equal pelagic input at all sites held true at this time, with no subsequent sediment redistribution, we would tend to interpret this pattern as evidence for a reduced Oligocene dissolution gradient over the depth interval between sites. Given that paleodepths for each of these sites probably ranged from 500 to 900 $\mathrm{m}$ shallower than present water depths during the course of the Oligocene (see Simmons, this volume; and discussion below), reduced dissolution gradients at a shallower level of the water column might be anticipated. On the other hand, examination of Figure 15 reveals numerous inconsistencies that suggest that the between-site MAR contrasts have been modified by the processes of reworking and downslope transport. For example, as noted earlier, carbonate MAR data for Site 710 exceed those of all other sites between about 28 and 33 Ma (Figs. 13 and 15), whereas the shallowest site (Site 707) consistently records some of the lowest accumulation rates of the Oligocene (Fig. 13). We think it likely, therefore, that the reduced accumulation gradients between transect sites at this time record some combination of the two mechanisms.

Paleogene sediments from these Leg 115 sites consist predominantly of nannofossil oozes and chalks, with carbonate MARs that generally average about $0.6 \mathrm{~g} / \mathrm{cm}^{2} / 1000$ yr. Typical carbonate flux rates from oligotrophic regions of the ocean tend to range between about 0.35 and $0.5 \mathrm{~g} / \mathrm{cm}^{2} / 1000 \mathrm{yr}$ (Thiede and Rea, 1981; Rea and Leinen, 1986). Given the likelihood that reworking has probably reduced the observed MARs somewhat at our shallow sites, it seems safe to suggest that Paleogene surface waters in this region supported at least moderate levels of productivity. The common occurrence of biogenic silica in sedi- ments of Eocene and early Oligocene age would tend to support this view.

The second major sedimentary regime encompasses most of the early and middle Miocene and is characterized by greatly reduced bulk and carbonate MARs at all of the transect sites (Fig. 13). The transition from the higher Paleogene rates to the low rates of this interval apparently begins in the latest Oligocene ( $\sim 24-25 \mathrm{Ma})$ and concludes somewhere between 22.5 (at Site 711) and 21.2 Ma (at Site 710). Our data would seem to suggest that the combined influence of several interrelated processes is probably at work here, with the relative contributions of increased carbonate dissolution, low productivity, and winnowing presumably varying as a function of site depth. At Site 707, the shallowest site, winnowing has clearly affected the accumulation record, as it has at nearby Site 237 (Thiede, 1974). At deeper sites, the presence of reworked materials and real and/or probable hiatuses in the early and middle Miocene interval indicate that some downslope redistribution of sediment has occurred.

At all sites, the effects of increased dissolution are clearly visible in the preservation of calcareous microfossils. Carbonate lost from the sediments as a result of dissolution must certainly account for a large fraction of the explanation for why carbonate MARs are so reduced, particularly at Sites 710 and 711. Finally, low surface productivity in this interval would seem to be generally indicated by the disappearance of biogenic silica near the Eocene/Oligocene boundary at all sites and its absence in the stratigraphic record until the late Miocene. Low concentrations of $\mathrm{Si}$ in the sediment pore waters suggest that this absence is at least partly due to limited biosiliceous production, and not 


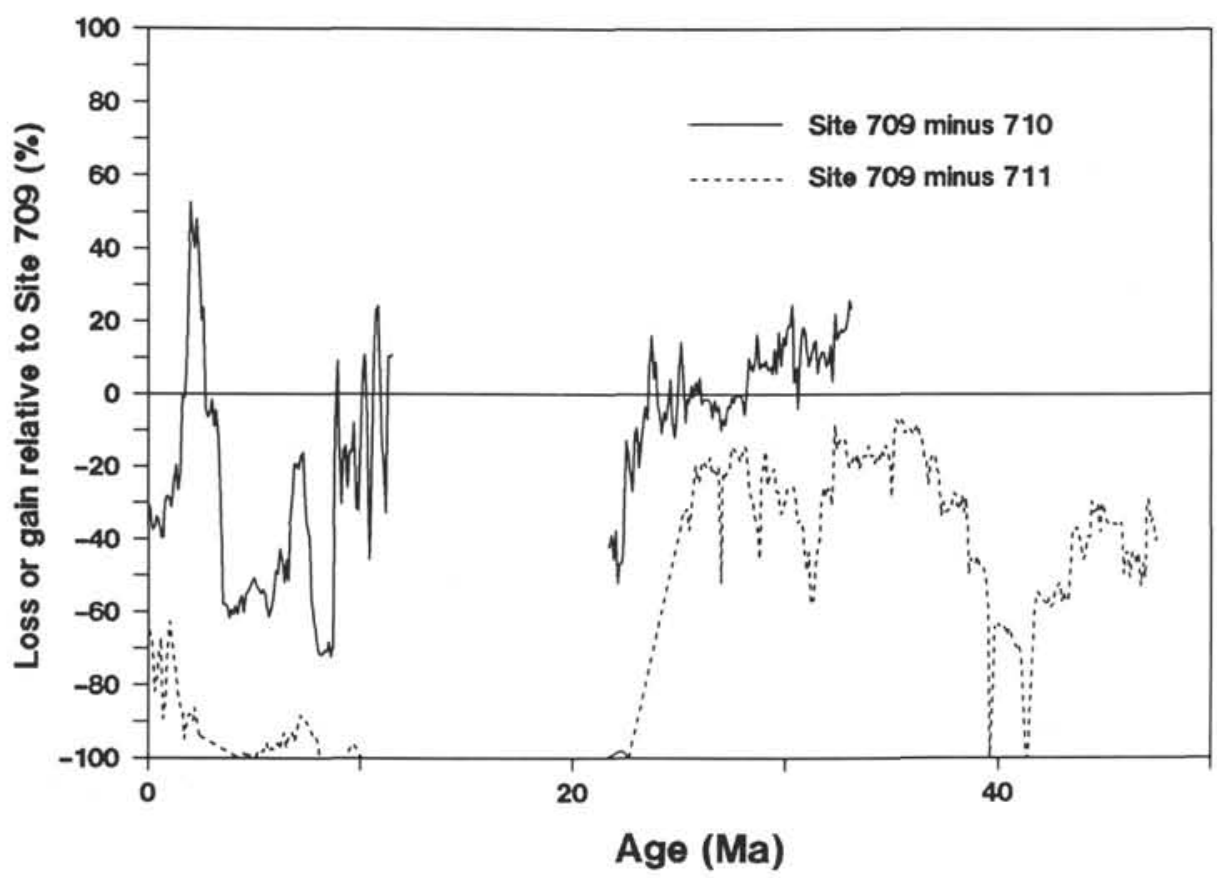

Figure 15. Carbonate accumulation at Sites 710 and 711 relative to accumulation at shallower Site 709. Accumulation at Sites 710 and 711 is expressed as percent change relative to Site 709, assuming that all three sites initially received the same pelagic input at any one time. Negative change indicates carbonate loss in the deeper sites and provides some measure of the dissolution gradient that must have existed in the past over the depth range that separates the three sites. Positive values indicate increased carbonate accumulation at the deeper sites relative to Site 709 and must point to some combination of shallow winnowing and downslope carbonate transport.

solely to postdepositional opal dissolution (P. K. Swart, pers. comm., 1989). A scenario calling for a reduced flux of carbonate to the deep seafloor is consistent with evidence for a shallower CCD in the early and middle Miocene because the position of the CCD is effectively determined by mass-balance considerations (input vs. loss), whereas carbonate preservation is at least partly a function of burial rate (e.g., Berger, 1978).

During the late Oligocene and throughout the Miocene, the gradual closure of the Indonesian and Tethyan seaways and the northward migration of the Indian subcontinent through the equatorial region (e.g., McKenzie and Sclater, 1971; Norton and Sclater, 1979) are likely to have had dramatic effects on sedimentation in the tropical Indian Ocean through the restriction of zonal circulation patterns. At the same time, tectonic events elsewhere, such as the opening of the Drake Passage near the Oligocene/Miocene boundary (Barker and Burrell, 1977), began to configure the ocean basins into a more modern approximation, resulting in changes in deep-water source areas and differing flow paths.

In their recent compilation of Miocene benthic foraminifer stable isotope and faunal abundance data, Woodruff and Savin (1989) showed that Miocene thermohaline circulation patterns were distinctly different from those of today. In particular, an examination of carbon isotope gradients between the major basins led them to speculate that the early Miocene ocean may have been strongly influenced by an influx of warm saline water from the Tethyan region into intermediate depths of the northern Indian Ocean. Such a scenario is at least broadly consistent with several lines of evidence stemming from Leg 115 studies. For example, the increased winnowing clearly recorded at shallow Site 707 through much of the Miocene is compatible with a more vigorous intermediate-water circulation. Similarly, Boersma (this volume), based on benthic foraminifers, concludes that well-oxygenated conditions were locally prevalent over much of the depth range of intermediate and deep waters through most of the early and middle Miocene. Boersma (this volume) also reports that redeposited benthic foraminifers in this interval are more likely to have come from the north than the south. Finally, our general inference of lower productivity in the early and middle Miocene, based largely on the absence of biogenic silica, is consistent, too, in the broad sense that areas adjacent to active sites of downwelling are inherently nutrient limited.

Evidence for a shallower CCD in the Miocene has existed since DSDP Leg 3 recovered red clays of that age in the South Atlantic (Maxwell et al., 1970). Since then, most reconstructions of the CCD have shown a clear shoaling trend from the Oligocene into the Miocene (e.g., van Andel, 1975; Heath et al., 1977; Hsü et al., 1984; Rea and Leinen, 1985), a trend similar to the one seen here. The study by Rea and Leinen (1985) of nearequatorial South Pacific sites is of particular interest, however, because of their observations of carbonate accumulation above the CCD. Based on an analysis of depth-dependent accumulation rate changes, Rea and Leinen (1985) proposed an increase in the thickness of the zone of dissolution that separates the lysocline and $\mathrm{CCD}$ in this region beginning in the early Miocene $(\sim 18 \mathrm{ma})$, an expansion that they tentatively ascribed to increased surface productivity. Rea and Leinen (1985) pointed out that such a conclusion is consistent with the model of Broecker and Peng (1982) that directly relates the thickness of this sublysocline zone (i.e., the vertical separation between the top of the lysocline and the $C C D$ ) to the downward flux of carbonate from the surface. Their conclusion is supported by evidence for increased equatorial Pacific productivity of both calcareous and siliceous organisms in the early Miocene (van Andel et al., 1975; Leinen, 1979).

Although the CCD trends that emerge from our data (see further discussion below) are very similar to Miocene CCD trends elsewhere, the evidence of Rea and Leinen (1985) ad- 
dressing the timing of productivity changes in the South Pacific and the development of a thick sublysocline zone would seem to differ considerably from what we observe. If real, these differences would seem to indicate that the first-order controls on the depth of the CCD and on carbonate accumulation patterns above may be somewhat uncoupled. Leinen (1979), for example, showed that equatorial Pacific productivity was already fairly high in the early Miocene, with increasing biogenic silica accumulation after about $17-18 \mathrm{Ma}$. At our Leg 115 sites, the reappearance of silica and the first evidence for high Neogene productivity substantially postdates this equatorial Pacific event (i.e., late Miocene; $\sim 8-9 \mathrm{Ma}$ ).

Our carbonate MAR data also show no evidence for a thickening of the sublysocline zone (based on an enhanced depth contrast in accumulation patterns) as early in the Miocene as observed by Rea and Leinen (1985). From this, we might tentatively conclude that the shape and intensity of dissolution profiles above the CCD are more directly related to regional fertility patterns, whereas the depth of the CCD itself has a more global forcing (sea level?). We are the first to admit, however, that our control on Miocene accumulation patterns at our shallow sites is far from ideal, particularly in the early Miocene. Clearly, we need to make more detailed comparisons of carbonate preservation between our shallow and deep sites to describe the vertical extent of the sublysocline zone during this time better. We also need to do more work to separate out, and compensate for, the effects of winnowing and reworking.

Within the early and middle Miocene record of Site 711, only a limited number of samples record any carbonate accumulation at all. Those that do tend to be found in the interval between about 13 and $16 \mathrm{Ma}$ and to coincide with an apparent peak in carbonate accumulation at Site 710 (Fig. 13). As discussed earlier, sedimentation rates at Site 710 at this time are presumably inflated somewhat because of turbidites of variable thickness that have expanded the section. One might logically expect Site 711 to contain redeposited carbonate as well. Our conclusion that some net accumulation of in-situ carbonate occurred at these sites is supported, however, by the work of Rio et al. (this volume), who report that the bulk of the dissolved nannofossil assemblages at Site 711 appear to be in place, and that the relative abundances of discoasterids decrease at this time at Site 710 . We also note early results of Leg 121 drilling on Broken Ridge, discussed by Rea et al. (in press), that show reduced winnowing at intermediate depth sites between 13 and $16 \mathrm{Ma}$, in contrast to much of the early and middle Miocene section there for which grain-size analyses indicate increased current activity.

Unlike the gradual transition ( $\sim 3$ m.y.) that separates the accumulation regime of the Paleogene from that of the early and middle Miocene, the transition that took place in the late Miocene seems to have taken no more than a few hundred thousand years. From that time to the present $(\sim 8-0 \mathrm{Ma})$, shallow sites record the highest local bulk and carbonate MARs of the last 50 m.y., biogenic silica returns to the sediments, and the first substantial depth gradients in carbonate accumulation are found (Figs. 13 and 14), data indicating, when taken together, that circulation patterns in the tropical Indian Ocean were an approximation of those found today.

The major rise in carbonate MARs takes place at about 8 $\mathrm{Ma}$, with an age discrepancy of about $0.8 \mathrm{~m}$.y. between the estimates obtained from shallow (Sites 707/709) and deep (Sites $710 / 711)$ sites. As discussed earlier, this difference is likely an artifact of our age models rather than a true diachronous response. From 8 through approximately $3 \mathrm{Ma}$, the carbonate MARs at Sites 707 and 709 exceed $1.0 \mathrm{~g} / \mathrm{cm}^{2} / 1000 \mathrm{yr}$ and are virtually identical to each other, implying fairly rapid deposition and very little loss of carbonate to dissolution over the depth range that separates the two sites $(\sim 1500 \mathrm{~m})$. The evidence for high productivity in this interval is unmistakeable. Biogenic silica reappears in the record in the form of radiolarians and sponge spicules at about $10 \mathrm{Ma}$, with diatoms becoming the dominant constituent around $8 \mathrm{Ma}$ (Johnson, this volume; Mikkelsen, this volume). The diatom assemblages themselves contain high relative abundances of the Thalassionema group, taxa characteristic of highly productive upwelling conditions (Mikkelsen, this volume).

There is also lithostratigraphic evidence for higher surface productivity in the late Miocene-early Pliocene based simply on sediment color. Sediments of this age at Sites 709, 710, and 711 were consistently found to be various shades of gray to greenish gray in color, whereas sediments stratigraphically above and below were uniformly white, yellowish brown, to buff in color (Backman, Duncan, et al., 1988). The color differences observed were obvious enough to form the basis for defining lithostratigraphic subunits at sea that presumably reflect the oxidation state, with the greenish gray hues of the late Miocene-early Pliocene sediments indicating reducing conditions, and probably related to some combination of high initial organic carbon input or enhanced organic carbon preservation. Additional evidence comes from low measured values of whole-core magnetic susceptibility in this "reduced" interval that are attributed by Robinson (this volume) to the effects of suboxic diagenesis on the natural remanent magnetization-carrying iron oxides and oxyhydroxides in the sediments. At around $3 \mathrm{Ma}$, a marked decline in the accumulation of silica and decreased abundances of Thalassionema at all sites are consistent with the scenario of reduced surface productivity that is implied by the pronounced drop in carbonate MARs.

Between 8 and $3 \mathrm{Ma}$, the contrast between carbonate accumulation at shallow sites and deep sites is at a maximum. Because the sites in this transect are so close together, we assume that they have experienced a common subsidence history and that the vertical separation between sites has remained approximately constant through time. As such, the large depth-dependent MAR contrast during this interval indicates the strongest dissolution gradient between sites over the last 50 m.y. (Figs. 13 and 15). If we interpret the "lysocline" as the depth level where carbonate loss from the sediments begins in earnest, then this level clearly must have fallen between the paleodepths of Sites 709 and 710 during the late Miocene and early Pliocene.

Sites 710 and 711 both show a rise in carbonate MARs early on in the late Miocene-early Pliocene interval, and then a drop at the time when accumulation at Sites 707 and 709 reaches its peak. At about the early/late Pliocene boundary (3.4 Ma), several of the sites show a marked reduction in carbonate MARs, followed almost a million years later $(2.5 \mathrm{Ma})$ by a MAR rise. Site 711 is essentially barren of carbonate during this interval, indicating that the CCD shoaled briefly before beginning its final drop in the late Pliocene to its present level. The timing of the rise in carbonate MARs at about $2.5 \mathrm{Ma}$, most clearly visible in the record of Site 711, suggests a possible linkage between changes in boundary conditions that must have accompanied the onset of Northern Hemisphere glaciation (Shackleton et al., 1984) and carbonate preservation in the equatorial Indian Ocean.

The record of Site 709 is probably most indicative of shallow accumulation patterns in the late Pliocene-Pleistocene interval since Site 707 shows clear evidence of increased winnowing after about 3.5 Ma. Carbonate accumulation at Site 709 peaks at rates of between $0.8-0.9 \mathrm{~g} / \mathrm{cm}^{2} / 1000 \mathrm{yr}$, values that are comparable to late Quaternary fluxes in the eastern equatorial Indian Ocean (L. C. Peterson, unpubl. data). Carbonate flux rates across the equatorial Indian Ocean are lower than Quaternary carbonate MARs in both the equatorial Pacific $\left(\sim 1-3 \mathrm{~g} / \mathrm{cm}^{2}\right.$ ) 
1000 yr; Chuey et al., 1987; Lyle et al., 1988) and the monsooninfluenced Arabian Sea ( 1-3 g/ $\mathrm{cm}^{2} / 1000 \mathrm{yr}$; Prell, Niitsuma, et al., 1989), but tend to parallel the modern differences in primary production between the regions (Berger et al., 1987). The records of Sites 710 and 708 (Fig. 14) over the last 3-4 m.y. show similar general accumulation trends, but differ in certain details in ways that are not currently understood. More specific relationships between patterns in the Leg 115 carbonate records in this interval and known paleoceanographic events will come from more detailed studies of these materials.

Although our records from the five transect sites indicate differences between the early and later parts of the last $8 \mathrm{~m}$.y., the dramatic rise in carbonate accumulation that began about 8 $\mathrm{Ma}$, and the ancillary evidence for enhanced productivity and dissolution gradients, would seem to indicate the onset of nearmodern circulation patterns in the surface and deep ocean. Studies of carbon isotopic gradients in the deep ocean, as recorded by benthic foraminifers, tend to agree that thermohaline circulation began to resemble its modern patterns about this time (e.g., Woodruff and Savin, 1989). In the Arabian Sea to the north, Leg 117 was charged with the task of investigating the long-term evolution of the Indian Ocean Monsoon and its associated oceanographic phenomena. The early results of this leg (Prell, Niitsuma, et al., 1989) have shown that silica deposition first began in the western Arabian Sea in the late middle Miocene, whereas high carbonate $\left(2-4 \mathrm{~g} / \mathrm{cm}^{2} / 1000 \mathrm{yr}\right)$ and organic carbon accumulation rates and the appearance of upwelling faunas in the late Miocene indicate that the monsoon was clearly active. Carbonate MARs at Leg 117 sites from the Owen Ridge then decrease to values of $1-2 \mathrm{~g} / \mathrm{cm}^{2} / 1000 \mathrm{yr}$ in the Pliocene, before rising again to Quaternary levels. The similarity of these results to what has been described here from Leg 115 no doubt indicates that patterns of surface productivity across the western equatorial Indian Ocean and Arabian Sea have a common evolution.

Whether these results are part of a signal that is local to the Indian Ocean, or one that is more global in scope, is not yet clear. Vincent (1974), for example, concluded from Leg 24 data that the modern high-productivity belt in the equatorial Indian Ocean formed in the middle to late Miocene after the passage of India across the equator. However, high accumulation rates in the late Miocene have been reported from the Caribbean and equatorial Pacific as well (e.g., Leinen, 1979; Prell, Gardner, et al., 1982; Theyer et al., 1984). Leinen (1979) showed that biogenic silica deposition in the equatorial Pacific, which began to increase in the early Miocene, reached a maximum between about 10 and $8 \mathrm{Ma}$ and suggested that this event recorded an intensification of the southeast trade winds. Rea and Bloomstine (1986), based on eolian grain-size data from South Pacific cores, supported this conclusion of trade wind intensification with evidence of a pronounced coarsening in eolian grains at about $10.5 \mathrm{Ma}$.

In addition, comparison of eolian grain-size data from both North and South Pacific sites led Rea and Bloomstine (1986) to conclude further that the Southern Hemisphere has had the more intense atmospheric circulation of the two hemispheres throughout the Neogene, and that this asymmetry reached its greatest extent between the event at 10.5 and about $2.5 \mathrm{Ma}$. Although the major rise in carbonate MARs recorded at our Leg 115 sites (Fig. 13) would appear to come later $(\sim 8 \mathrm{Ma})$, the abrupt reappearance of biogenic silica in these sediments at about $10 \mathrm{Ma}$ and the sharp drop in MARs at about $3 \mathrm{Ma}$ fit reasonably well with the inferred timing of this interval, suggesting perhaps that equatorial upwelling is responding on a more global basis to intensified atmospheric circulation in the Southern Hemisphere.

\section{History of CCD Motion}

Although it is reasonable to expect the vertical separation between transect sites to have remained more or less constant throughout time, a more quantitative knowledge of their combined subsidence history is required to place meaningful constraints on the range of past CCD motion and to evaluate better the observed carbonate accumulation patterns as a function of paleobathymetry. Individual subsidence histories for the sites in this transect were modeled by Simmons (this volume) with standard back-tracking techniques (e.g., Sclater et al., 1985); a detailed discussion of the assumptions and parameters used in these calculations can be found in these two papers. Here, we use the resulting estimates of site-specific paleobathymetry, combined with our data on carbonate MARs, to produce an age-paleodepth reconstruction of the CCD and of the carbonate deposition above it (Fig. 16).

van Andel (1975) attempted the first such analysis of Indian Ocean CCD behavior on the basis of preliminary drilling results from DSDP Legs 22 through 27 . His reconstruction for the $\mathrm{Ce}-$ nozoic shows a generally shallow CCD $(<4000 \mathrm{~m})$ until the late Eocene, followed by a steady drop to around $4400 \mathrm{~m}$ in the late Oligocene and a steep rise to above $4000 \mathrm{~m}$ in the middle Miocene. This was followed by an equally steep drop in the CCD to its present-day level. A second attempt at an Indian Ocean CCD analysis by Sclater et al. (1977), with an expanded suite of sites, differed in several important ways. The latter reconstruction shows that the CCD remained at about $4000 \mathrm{~m}$ for most of the Cenozoic only to drop sharply to its modern level after the Miocene. Although their data shows considerable variability during the Eocene and Miocene, which implies shoaling of the CCD at these times, Sclater et al. (1977) attributed most of the scatter to circumstances related to site location and record completeness.

The zero isopleth in Figure 16, the level at which no net accumulation of carbonate occurs, by definition records the depth of the CCD. For most of the Neogene, the range and timing of CCD motion can be reasonably well constrained with our data. From its initial crossing of Site 711 near the Oligocene/Miocene boundary on its rise to an early Miocene high, the CCD appears to have deepened and shoaled twice more before beginning the final drop to its present-day level at about $5000 \mathrm{~m}$. Although the timing of these Neogene excursions is largely based on the record at Site 711 , the motions are consistent with the changes in carbonate MARs observed at the shallower sites. We have inferred here that the CCD reached its shallowest Neogene position in the early Miocene primarily because the data gap at this time at Site 708 represents a hiatus, whereas the middle Miocene gap at Site 710 represents data discarded because the sequence was slumped. We have also inferred that the CCD dropped slightly between its early and middle Miocene highs because of the small rise in MARs, and enhanced preservation, recorded at Sites 711,710 , and 708 from about $14-16 \mathrm{Ma}$. Based on carbonate MAR patterns in the early Pliocene, the final rise of the CCD in the Neogene was less pronounced than the previous two. The total range of motion described for the Neogene CCD is on the order of a kilometer or more.

Our reconstruction of the Indian Ocean CCD compares favorably with what is known about $C C D$ history in the nearequatorial South Pacific. As noted previously, the reconstruction of Rea and Leinen (1985) shows that the CCD began shoaling in that ocean before $20 \mathrm{Ma}$, peaked between about 20 and 14 $\mathrm{Ma}$, and deepened since then to its present level. The increased detail that our reconstruction shows within the Neogene as compared with previous Indian Ocean reconstructions (van Andel, 1975; Sclater et al., 1977) can be seen in Figure 17. Although our inference of a small drop in the CCD centered at about 15 


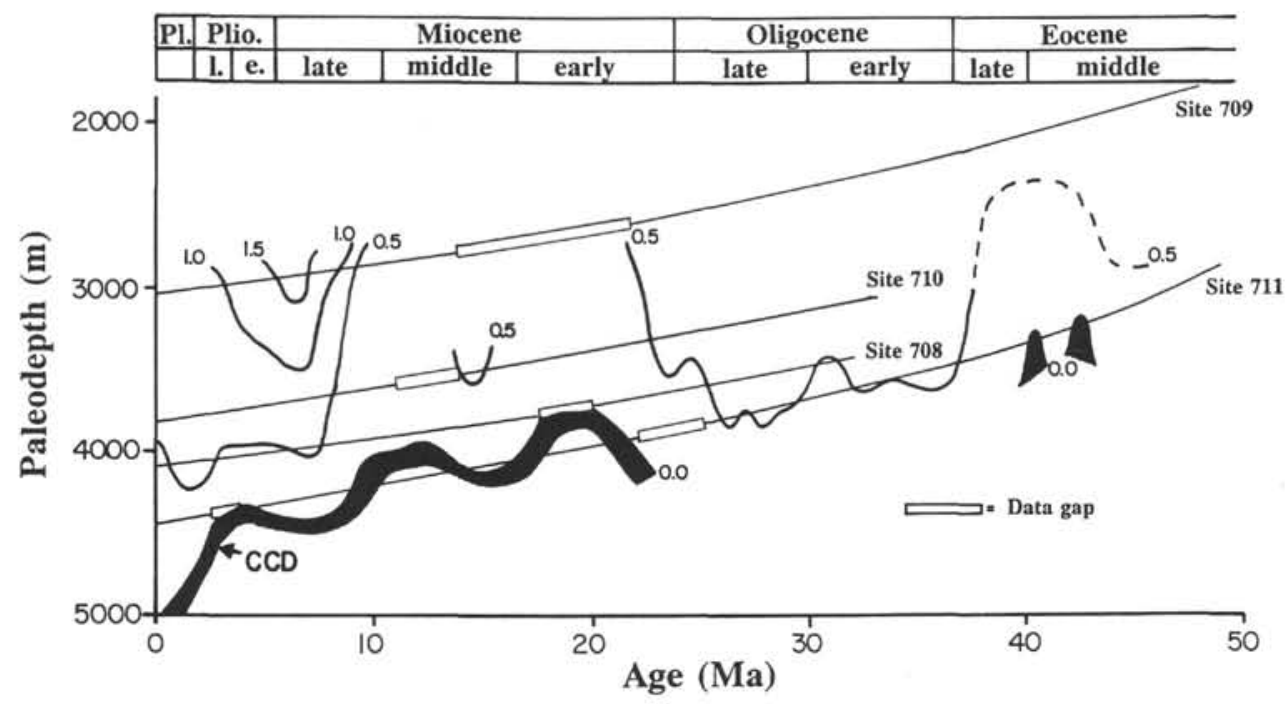

Figure 16. Bathymetric variations in carbonate mass accumulation $\left(\mathrm{g} \mathrm{CaCO}_{3} / \mathrm{cm}^{2} / 1000 \mathrm{yr}\right.$ ) through the late Cenozoic of the western equatorial Indian Ocean. Carbonate MAR data from Sites 709, 710, 708, and 711 (in order of increasing water depth) were plotted as a function of estimated age and paleodepth before contouring. Data from Site 707 were excluded from this figure largely because of its much shallower water depth and because its carbonate MAR record added no significant information. Details on the subsidence models used for these sites can be found in Simmons (this volume). The zero $\mathrm{g} / \mathrm{cm}^{2} / 1000 \mathrm{yr}$ isopleth marks the time-dependent history of the carbonate compensation depth (CCD).

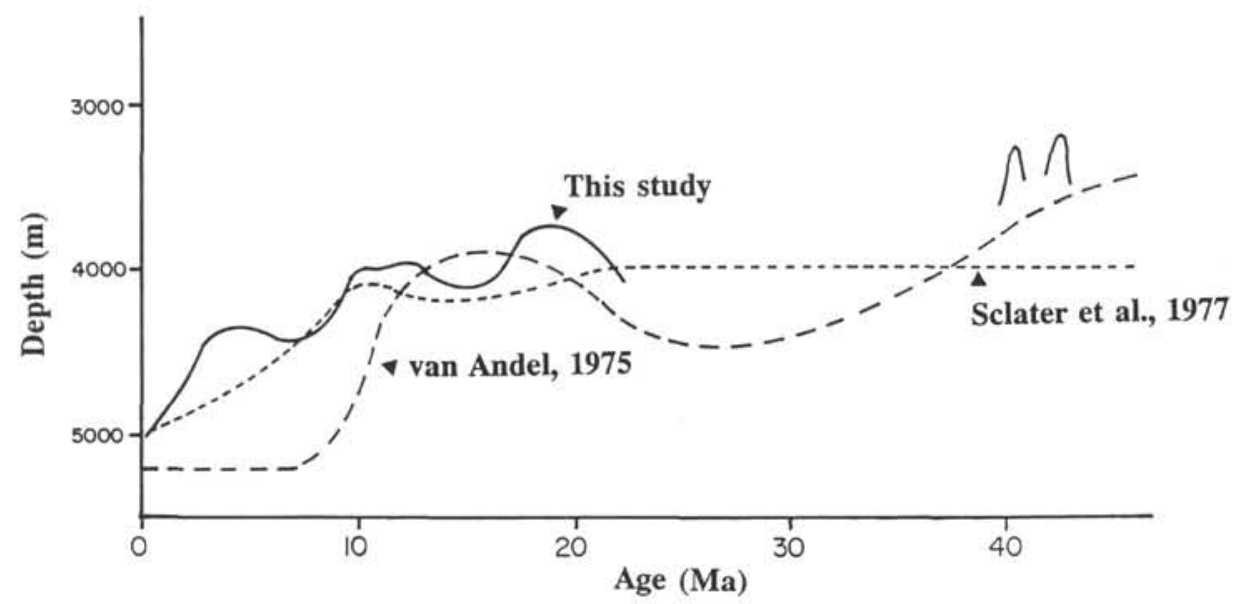

Figure 17. Comparison of the late Cenozoic CCD history derived from this study with the previous CCD reconstructions of van Andel (1975) and Sclater et al. (1977).

$\mathrm{Ma}$ is perhaps open to debate, we consider the evidence for the early Pliocene shoaling event to be strong. In addition, thanks to continuous coring and an improved stratigraphic framework for this study, the timing of events in the Neogene is much better constrained here than in those earlier reconstructions.

Before its initial rise near the Oligocene/Miocene boundary, we have little direct control on the depth of the CCD in the Paleogene. However, the high carbonate content at all sites (Fig. 6), the moderately high carbonate MARs (Fig. 13), and the uniformity of both among the sites would seem to support the deeper depth estimates of van Andel (1975; Fig. 17) for at least the Oligocene. As noted earlier, none of the Leg 115 sites record a CCD crossing that can be related to the well-known drop of the CCD across the Eocene/Oligocene boundary, implying that all of the sites must have been above the CCD when the drop oc- curred. The absence of carbonate accumulation over short intervals at Site 711 between about 39 and 42 Ma suggests, nevertheless, the existence of several brief CCD excursions near the middle/late Eocene boundary. If the subsidence model used for Site 711 is correct, the CCD would appear to have reached its shallowest position of the last 50 m.y. at this time.

The gradients in carbonate accumulation above the CCD are also visible in Figure 16, though the details are blurred because of the use of so few contours. Significant gradients in carbonate accumulation have existed between sites only since the late Miocene, a period during which shallow sites experienced carbonate deposition at the highest rates of the last $50 \mathrm{~m} . \mathrm{y}$. Before the late Miocene, the fact that the $0.5 \mathrm{~g} / \mathrm{cm}^{2} / 1000 \mathrm{yr}$ isopleth can be used to describe the entire accumulation record is testimony to our observation that all of the sites record very similar between- 
site accumulation histories, even though the absolute differences in accumulation change greatly from the Paleogene to the early-middle Miocene. The position of the $0.5 \mathrm{~g} / \mathrm{cm}^{2} / 1000 \mathrm{yr}$ isopleth in the middle and late Eocene is very speculative and is inferred from the gradient between Sites 709 and 711 shown in Figure 13. The apparent gradual drop of this isopleth through the late Eocene, however, may be related to the well-known CCD deepening that occurred across the Eocene/Oligocene boundary.

\section{CONCLUSIONS}

Quantitative estimates of the flux of biogenic carbonate to the seafloor and of the rates and patterns of its subsequent dissolution are key components to understanding past ocean history, and particularly the global carbon cycle. Our study of carbonate accumulation at the five-site depth transect drilled by Leg 115 provides the first such quantitative synthesis for the tropical Indian Ocean, a synthesis that reveals a series of pronounced changes in the pelagic carbonate system during the late Cenozoic.

In general, we recognize three major sedimentary regimes on the basis of average carbonate accumulation rates and depth-dependent accumulation patterns. Throughout much of the Paleogene, carbonate accumulation at the five sites is characterized by moderate rates and reduced between-site differences that together imply relatively stable biogenic production at the surface and some combination of weak dissolution gradients and/or sediment redistribution over the depth range that separates the sites. The exception to the latter generalization seems to occur near the middle/late Eocene boundary where our data suggest enhanced dissolution and a brief shallowing of the CCD.

The second regime begins with a gradual transition $(\sim 3$ m.y.) that spans the Paleogene/Neogene boundary and ends with an abrupt rise in carbonate MARs at about $8 \mathrm{Ma}$. The early to early late Miocene interval is characterized by greatly reduced carbonate MARs across the five sites, small between-site accumulation differences, and generally poor preservation of calcareous microfossils. Accumulation rates are at their lowest here as a result of increased dissolution and winnowing, and a probable drop in surface productivity, with the contributions of the first two varying more as a function of site depth.

Carbonate accumulation in the third regime, which encompasses the late Neogene ( $8-0 \mathrm{Ma})$, is marked by the highest observed MARs of the late Cenozoic in this region and by the first substantial contrasts in accumulation between sites. The high accumulation rates at shallow sites, the reappearance of biogenic silica in the sediments, and the greater depth-dependent loss of carbonate argues for the onset of near-modern depositional conditions, with increased levels of surface productivity and the development of a strong dissolution gradient in the water column at depth.

Our reconstruction of past CCD behavior in the tropical Indian Ocean, and particularly the shoaling observed in the early and middle Miocene, is generally compatible with first-order CCD reconstructions from the other major ocean basins (see Hay, 1988, for a compilation). Berger (1970) and Berger and Winterer (1974) were among the first investigators to suggest that carbonate partitioning between shallow and deep seas, modulated by sea-level changes, was the causal mechanism responsible for the common element of long-term CCD variations. As noted by Hay (1988), general support for this hypothesis has come with the subsequent publication of eustatic sealevel records by Vail et al. (1977) and Haq et al. (1987).

Although we have no clear reason to dispute sea level as having the ultimate control on the depth of the CCD, our data indicate that the controls on dissolution gradients and carbonate accumulation patterns above the CCD may have more complex origins, and perhaps exhibit more interregional variability, than expected. As an example of this in the Neogene, we note again the apparently later onset of siliceous sedimentation at the Leg 115 transect sites in the late Miocene (8-10 Ma) as compared with the early Miocene appearance of biogenic silica in sediments from the eastern equatorial Pacific $(\sim 18 \mathrm{Ma})$. The CCD has had nearly identical behavior in both regions across this interval, suggesting a weak link with local productivity. Above the $\mathrm{CCD}$, however, there appear to have been substantial differences in the gradients of carbonate accumulation between regions, which may indicate real differences in the shape and intensity of the respective dissolution profiles. Further investigation of depth gradients in the flux and preservation of carbonate above the CCD should lead to better models of the time-dependent development of the lysocline and a better understanding of these interocean differences and their underlying paleoceanographic causes.

\section{ACKNOWLEDGMENTS}

We would like to thank the Shipboard Scientific Party, the ODP technical and logistics personnel, and the crew and drilling operations staff of the JOIDES Resolution for their combined efforts on behalf of the Leg 115 scientific program. Special thanks go to T. Frank and K. Sigler-Tauxe for producing the shipboard carbonate data, and to M. Sands and M. Lynn for their help in the shore-based analyses. Reviews by D. K. Rea and an anonymous referee greatly improved this manuscript. We appreciate helpful discussions with P. Swart and S. Burns, and the hard work of R. Dunbar, the Editorial Review Board member assigned to this paper.

Our post-cruise research was supported by funds from the JOI-USSAC (to L. C. Peterson) and the Swedish Natural Science Research Council (to J. Backman). This is a contribution from the Rosenstiel School of Marine and Atmospheric Science, University of Miami.

\section{REFERENCES}

Arrhenius, G., 1950. Late Cenozoic climatic changes recorded by the equatorial current system. Tellus, 2:83-88.

1952. Sediment cores from the East Pacific. Rep. Swed. DeepSea Exped. 1947-1948, No. 5.

Backman, J., Duncan, R. A., et al., 1988. Proc. ODP, Init. Repts., 115: College Station, TX (Ocean Drilling Program).

Barker, P. F., and Burrell, J., 1977. The opening of Drake Passage. Mar. Geol., 25:15-34.

Benson, R. H., 1975. The origin of the psychrosphere as recorded in changes of deep-sea ostracode assemblages. Lethaia, 8:69-83.

Berger, W. H., 1968. Planktonic foraminifera: selective solution and paleoclimatic interpretation. Deep-Sea Res., 15:31-43.

1970. Biogenous deep-sea sediments: fractionation by deepsea circulation. Geol. Soc. Am. Bull., 81:1385-1402.

1973. Cenozoic sedimentation in the eastern tropical Pacific. Geol. Soc. Am. Bull., 84:1941-1954.

1975. Deep-sea carbonates: dissolution profiles from foraminiferal preservation. In Sliter, W. V., Bé, A.W.H., and Berger, W. H. (Eds.), Dissolution of Deep-Sea Carbonate. Spec. Publ., Cushman Found. Foraminiferal Res., 13:82-86.

1978. Sedimentation of deep-sea carbonate: maps and models of variations and fluctuations. J. Foraminiferal Res., 8:286-302.

Berger, W. H., Fischer, K., Lai, C., and Wu, G., 1987. Ocean productivity and organic carbon flux. Part I. Overview and maps of primary production and export production. Univ. of California, San Diego, SIO Reference 87-30.

Berger, W. H., and Winterer, E. L., 1974. Plate stratigraphy and the fluctuating carbonate line. In Hsü, K. J., and Jenkyns, H. C. (Eds.), Pelagic Sediments on Land and Under the Sea: London (Blackwell Sci. Publ.): 11-48.

Berggren, W. A., Kent, D. V., and Flynn, J. J., 1985a. Jurassic to Paleogene: Part 2. Paleogene geochronology and chronostratigraphy. In Snelling, N. J. (Ed.), The Chronology of the Geologic Record. Geol. Soc. Mem. (London), 10:141-195.

Berggren, W. A., Kent, D. V., and Van Couvering, J. A., 1985b. The Neogene: Part 2. Neogene geochronology and chronostratigraphy. 
In Snelling, N. J. (Ed.), The Chronology of the Geologic Record. Geol. Soc. Mem. (London), 10:211-260.

Bramlette, M. N., 1961. Pelagic sediments. In Sears, M. (Ed.), Oceanography. Am. Assoc. Adv. Sci. Publ., 67:345-366.

Broecker, W. S., and Peng, T.-H., 1982. Tracers in the Sea: Palisades, NY (Eldigio Press).

1987. The role of $\mathrm{CaCO}_{3}$ compensation in the glacial to interglacial atmospheric $\mathrm{CO}_{2}$ change. Global Biogeochem. Cycles, 1: 15-29.

Chuey, J. M., Rea, D. K., and Pisias, N. G., 1987. Late Pleistocene paleoclimatology of the central equatorial Pacific: a quantitative record of eolian and carbonate deposition. Quat. Res., 28:323-339.

Corliss, B. H., Aubry, M.-P., Berggren, W. A., Fenner, J. M., Keigwin, L. D., and Keller, G., 1984. The Eocene/Oligocene boundary event in the deep sea. Science, 226:806-810.

Corliss, B. H., and Keigwin, L. D., 1986. Eocene/Oligocene paleoceanography. In Hsü, K. J. (Ed.), Mesozoic and Cenozoic Oceans: Washington (Am. Geophys. Union). Geodynamics Series, 15:101-118.

Fillon, R. H., 1972. Evidence from the Ross Sea for widespread submarine erosion. Nature Phys. Sci., 238:40-42.

Haq, B. U., 1981. Paleogene paleoceanography: early Cenozoic ocean revisited. Oceanol. Acta, Proceedings 26th International Geological Congress, Geology of Oceans Symposium, Paris, July 7-17: 71-82.

Haq, B. U., Hardenbol, J., and Vail, P. R., 1987. Chronology of fluctuating sea levels since the Triassic. Science, 235:156-1167.

Hay, W. W., 1988. Paleoceanography: a review for the GSA Centennial. Geol. Soc. Am. Bull., 100:1934-1956.

Hay, W. W., and Southam, J. R., 1977. Modulation of marine sedimentation by the continental shelves. In Andersen, N. R., and Malahoff, A. (Eds.), The Role of Fossil Fuel $\mathrm{CO}_{2}$ in the Oceans: New York (Plenum Press), 569-605.

Heath, G. R., 1969. Carbonate sedimentation in the abyssal equatorial Pacific during the past 50 million years. Geol. Soc. Am. Bull., 80: 689-694.

Heath, G. R., Moore, T. C., Jr., and van Andel, T. H., 1977. Carbonate accumulation and dissolution in the equatorial Pacific during the past 45 million years. In Andersen, N. R., and Malahoff, A. (Eds.), The Fate of Fossil Fuel $\mathrm{CO}_{2}$ in the Oceans: New York (Plenum Press), 627-639.

Hsü, K. J., McKenzie, J. A., Oberhänsli, H., Weissert, H., and Wright, R. C., 1984. South Atlantic Cenozoic paleoceanography. In Hsü, K. J., LaBrecque, J. L., et al., Init. Repts. DSDP, 73: Washington (U.S. Govt. Printing Office), 771-785.

Jones, G. A., and Kaiteris, P., 1983. A vacuum-gasometric technique for rapid and precise analysis of calcium carbonate in sediments and soils. J. Sediment. Petrol., 53:655-660.

Keigwin, L. D., 1980. Paleoceanographic change in the Pacific at the Eocene/Oligocene boundary. Nature, 287:722-725.

Kennett, J. P., 1982. Marine Geology: Englewood Cliffs, NJ (PrenticeHall).

Kennett, J. P., and Watkins, N. D., 1976. Regional deep-sea dynamic processes recorded by late Cenozoic sediments of the southeastern Indian Ocean. Geol. Soc. Am. Bull., 87:321-339.

Kidd, R. B., and Davies, T. A., 1978. Indian Ocean sediment distribution since the late Jurassic. Mar. Geol., 26:49-70.

Kolla, V., Bé, A.W.H., and Biscaye, P. E., 1976. Calcium carbonate distribution in the surface sediments of the Indian Ocean. J. Geophys. Res., 81:2605-2616.

Ledbetter, M. T., Williams, D. F., and Ellwood, B. B., 1978. Late Pliocene climate and southwest Atlantic abyssal circulation. Nature, 272:237-239.

Leinen, M., 1979. Biogenic silica accumulation in the central equatorial Pacific and its implications for Cenozoic paleoceanography. Geol. Soc. Am. Bull., Part II, 90:1310-1376.

Leinen, M., Cwienk, D., Heath, G. R., Biscaye, P. E., Kolla, V., Thiede, J., and Dauphin, J. P., 1986. Distribution of biogenic silica and quartz in recent deep-sea sediments. Geology, 14:199-203.

Lyle, M., Murray, D. W., Finney, B. P., Dymond, J., Robbins, J. M., and Brooksforce, K., 1988. The record of late Pleistocene biogenic sedimentation in the eastern tropical Pacific Ocean. Paleoceanography, 3:39-59.

McKenzie, D. P., and Sclater, J. G., 1971. The evolution of the Indian Ocean since the late Cretaceous. Geophys. J. R. Astron. Soc., 25: 437-528.
Maxwell, A. E., Von Herzen, R. P., et al., 1970. Init. Repts. DSDP, 3: Washington (U.S. Govt. Printing Office).

Miller, K. G., Fairbanks, R. G., and Mountain, G. S., 1987. Tertiary oxygen isotope synthesis, sea level history, and continental margin erosion. Paleoceanography, 2:1-19.

Moore, T. C., Jr., Rabinowitz, P. D., et al., 1984. Init. Repts. DSDP, 74: Washington (U.S. Govt. Printing Office).

Norton, I. O., and Sclater, J. G., 1979. A model for the evolution of the Indian Ocean and the breakup of Gondwanaland. J. Geophys. Res., $84: 6803-6830$.

Peterson, L. C., and Prell, W. L., 1985. Carbonate dissolution in Recent sediments of the eastern equatorial Indian Ocean: preservation patterns and carbonate loss above the lysocline. Mar. Geol., 64:259290.

Pisias, N. G., and Prell, W. L., 1985. High resolution carbonate records from the hydraulic piston cored section of Site 572. In Mayer, L., Theyer, F., Thomas, E., et al., Init. Repts. DSDP, 85: Washington (U.S. Govt. Printing Office), 711-722.

Prell, W. L., Gardner, J. V., et al., 1982. Init. Repts. DSDP, 68: Washington (U.S. Govt. Printing Office).

Prell, W. L., Niitsuma, N., et al., 1989. Proc. ODP, Init, Repts., 117: College Station, TX (Ocean Drilling Program).

Rea, D. K., and Bloomstine, M. K., 1986. Neogene history of the South Pacific tradewinds: evidence for hemispherical asymmetry of atmospheric circulation. Palaeogeogr., Palaeoclimatol., Palaeoecol., 55: 55-64.

Rea, D. K., Dehn, J., Driscoll, N. W., Farrell, J., Janecek, T. R., Owen, R. M., Pospichal, J. J., Resiwati, P., and the ODP Leg 121 Scientific Party, in press. Paleoceanography of the eastern Indian Ocean from ODP Leg 121 drilling on Broken Ridge. Geol. Soc. Am. Bull.

Rea, D. K., and Leinen, M., 1985. Neogene history of the calcite compensation depth and lysocline in the South Pacific Ocean. Nature, 316:805-807.

1986. Neogene controls on hydrothermal activity and paleoceanography of the southeast Pacific. In Leinen, M., Rea, D. K., et al., Init. Repts. DSDP, 92: Washington (U.S. Govt. Printing Office), 597-617.

Ruddiman, W. F., Cameron, D., and Clement, B. M., 1987. Sediment disturbance and correlation of offset holes drilled with the hydraulic piston corer: Leg 94. In Ruddiman, W. F., Kidd, R. B., Thomas, E., et al., Init. Repts. DSDP, 94, Pt. 2: Washington (U.S. Govt. Printing Office), 615-634

Sclater, J. G., Abbott, D., and Thiede, J., 1977. Paleobathymetry and sediments of the Indian Ocean. In Heirtzler, J. R., Bolli, H. M., Davies, T. A., Saunders, J. B., and Sclater, J. G. (Eds.), Indian Ocean Geology and Biostratigraphy: Washington (American Geophysical Union), 25-60.

Sclater, J. G., Meinke, L., Bennett, A., and Murphy, C., 1985. The depth of the ocean through the Neogene. In Kennett, J. P. (Ed.), The Miocene Ocean: Paleoceanography and Biogeography. Mem. Geol. Soc. Am., 163:1-19.

Shackleton, N. J., 1986. Paleogene stable isotope events. Palaeogeogr., Palaeoclimatol., Palaeoecol., 57:91-102.

Shackleton, N. J., Backman, J., Zimmerman, H. B., Kent, D. V., Hall, M. A., Roberts, D. G., Schnitker, D., Baldauf, J. G., Desprairies, A., Homrighausen, R., Huddlestun, P., Keene, J. B., Kaltenback, A. J., Krumsiek, K. A. O., Morton, A. C., Murray, J., and Westberg-Smith, J., 1984. Oxygen isotope calibration of the onset of icerafting in DSDP Site 552A: history of glaciation in the North Atlantic region. Nature, 307:620-623.

Shackleton, N. J., and Kennett, J. P., 1975. Paleotemperature history of the Cenozoic and the initiation of Antarctic glaciation: oxygen and carbon isotope analyses in DSDP Sites 277,279 , and 281. In Kennett, J. P., Houtz, R. E., et al., Init. Repts. DSDP, 29: Washington (U.S. Govt. Printing Office), 743-755.

Tchernia, P., 1980. Descriptive Regional Oceanography: New York (Pergamon Press).

Theyer, F., Mayer, L. A., Barron, J. A., and Thomas, E., 1984. The equatorial Pacific high-productivity belt: elements for a synthesis of Deep Sea Drilling Project Leg 85 results. In Mayer, L., Theyer, F., Thomas, E., et al., Init. Repts. DSDP, 85: Washington (U.S. Govt. Printing Office), 971-985.

Thiede, J., 1974. Sediment coarse fractions from the western Indian Ocean and the Gulf of Aden (Deep Sea Drilling Project Leg 24). In 
Fisher, R. L., Bunce, E. T., et al., Init. Repts. DSDP, 24: Washington (U.S. Govt. Printing Office), 651-765.

Thiede, J., and Rea, D. K., 1981. Mass accumulation rates of Barremian to Recent biogenic sediments from the Mid-Pacific Mountains (Deep Sea Drilling Project Site 463) and Hess Rise (Sites 464, 465, 466) central North Pacific Ocean. In Thiede, J., Vallier, T. L., et al., Init. Repts. DSDP, 62: Washington (U.S. Govt. Printing Office), 637-651.

Thunell, R. C., and Corliss, B. H., 1986. Late Eocene-early Oligocene carbonate sedimentation in the deep sea. In Pomerol, C., and Premoli Silva, I. (Eds.), Terminal Eocene Events: Amsterdam (Elsevier), 363-380.

Vail, P. R., Mitchum, R. M., Jr., and Thompson, S., III, 1977. Global cycles of relative changes of sea level. In Payton, C. E. (Ed.), Seismic Stratigraphy-Applications to Hydrocarbon Exploration. AAPG Mem., 26:83-97.

van Andel, T. H., 1975. Mesozoic-Cenozoic calcite compensation depth and the global distribution of calcareous sediments. Earth Planet. Sci. Lett., 26:187-194.

van Andel, T. H., Heath, G. R., and Moore, T. C., Jr., 1975. Cenozoic history and paleoceanography of the central equatorial Pacific. Mem. Geol. Soc. Am., No. 143.
Vincent, E., 1974. Cenozoic planktonic biostratigraphy and paleoceanography of the tropical western Indian Ocean. In Fisher, R. L., Bunce, E. T., et al., Init. Repts. DSDP, 24: Washington (U.S. Govt. Printing Office), 1111-1150.

Warren, B. A., 1981. Transindian hydrographic section at Lat. $18^{\circ} \mathrm{S}$ : property distributions and circulation in the South Indian Ocean. Deep-Sea Res., 28A:759-788.

Watkins, N. D., and Kennett, J. P., 1972. Regional sedimentary disconformities and upper Cenozoic changes in bottom water velocities between Australia and Antarctica. Antarct. Res. Ser., 19:317-334.

Woodruff, F., and Savin, S. M., 1989. Miocene deepwater oceanography. Paleoceanography, 4:87-140.

Wyrtki, K., 1973. Physical oceanography of the Indian Ocean. In Zeitzschel, B., and Gerlach, S. A. (Eds.), The Biology of the Indian Ocean: Berlin-Heidelberg-New York (Springer-Verlag), 18-36.

Date of initial receipt: 6 July 1989

Date of acceptance: 12 January 1990

Ms 115B-163 
APPENDIX A

This appendix contains a site-by-site listing of the depths (mbsf) and estimated ages of all samples used in this study, data on carbonate content, and the calculated mass accumulation rates (MAR: $\mathrm{g} / \mathrm{cm}^{2} / 1000 \mathrm{yr}$ ) for the bulk sediment, as well as for the carbonate and noncarbonate fractions. The origins of data gaps are detailed in the age model discussions of Appendix B. For Hole 708A, samples are listed with their original measured depths as well as their recalculated depths after turbidites thicker than $40 \mathrm{~cm}$ were subtracted from the section.

\begin{tabular}{|c|c|c|c|c|c|}
\hline $\begin{array}{l}\text { Depth } \\
\text { (mbsf) }\end{array}$ & $\begin{array}{l}\text { Age } \\
\text { (Ma) }\end{array}$ & $\begin{array}{c}\mathrm{CaCO}_{3} \\
(\%)\end{array}$ & $\begin{array}{l}\text { Bulk } \\
\text { MAR }\end{array}$ & $\begin{array}{c}\mathrm{CaCO}_{3} \\
\mathrm{MAR}\end{array}$ & $\begin{array}{c}\text { Non-CaCO } \\
\text { MAR }\end{array}$ \\
\hline \multicolumn{6}{|l|}{ Hole 707A: } \\
\hline 0.20 & 0.03 & 94.19 & 0.56 & 0.52 & 0.03 \\
\hline 0.80 & 0.12 & 95.61 & 0.56 & 0.53 & 0.02 \\
\hline 1.21 & 0.18 & 92.52 & 0.56 & 0.51 & 0.04 \\
\hline 1.33 & 0.20 & 88.17 & 0.56 & 0.49 & 0.07 \\
\hline 1.70 & 0.25 & 96.13 & 0.56 & 0.53 & 0.02 \\
\hline 2.30 & 0.34 & 96.21 & 0.52 & 0.50 & 0.02 \\
\hline 2.71 & 0.41 & 90.89 & 0.52 & 0.47 & 0.05 \\
\hline 2.83 & 0.42 & 94.17 & 0.52 & 0.49 & 0.03 \\
\hline 3.20 & 0.48 & 94.91 & 0.52 & 0.49 & 0.03 \\
\hline 3.80 & 0.57 & 89.77 & 0.52 & 0.47 & 0.05 \\
\hline 4.21 & 0.63 & 93.08 & 0.52 & 0.48 & 0.04 \\
\hline 4.33 & 0.65 & 94.35 & 0.52 & 0.49 & 0.03 \\
\hline 4.70 & 0.70 & 86.58 & 0.52 & 0.45 & 0.07 \\
\hline 5.30 & 0.79 & 96.65 & 0.46 & 0.44 & 0.02 \\
\hline 5.71 & 0.85 & 95.63 & 0.46 & 0.44 & 0.02 \\
\hline 5.83 & 0.87 & 94.15 & 0.46 & 0.43 & 0.03 \\
\hline 6.20 & 0.93 & 95.03 & 0.46 & 0.44 & 0.02 \\
\hline 6.46 & 0.97 & 94.87 & 0.46 & 0.43 & 0.02 \\
\hline 6.80 & 1.02 & 91.18 & 0.46 & 0.42 & 0.04 \\
\hline 7.40 & 1.11 & 91.03 & 0.46 & 0.42 & 0.04 \\
\hline 7.81 & 1.17 & 88.83 & 0.46 & 0.41 & 0.05 \\
\hline 7.93 & 1.19 & 93.85 & 0.46 & 0.43 & 0.03 \\
\hline 8.30 & 1.24 & 94.53 & 0.45 & 0.42 & 0.02 \\
\hline 8.90 & 1.33 & 94.80 & 0.45 & 0.42 & 0.02 \\
\hline 9.31 & 1.39 & 93.03 & 0.45 & 0.42 & 0.03 \\
\hline 9.43 & 1.41 & 94.79 & 0.45 & 0.42 & 0.02 \\
\hline 9.80 & 1.46 & 95.55 & 0.54 & 0.52 & 0.02 \\
\hline 10.40 & 1.54 & 81.76 & 0.56 & 0.46 & 0.10 \\
\hline 10.81 & 1.59 & 91.95 & 0.56 & 0.51 & 0.04 \\
\hline 10.93 & 1.60 & 93.87 & 0.56 & 0.52 & 0.03 \\
\hline 11.30 & 1.65 & 94.00 & 0.56 & 0.52 & 0.03 \\
\hline 11.90 & 1.72 & 94.01 & 0.56 & 0.52 & 0.03 \\
\hline 12.31 & 1.77 & 88.54 & 0.56 & 0.49 & 0.06 \\
\hline 12.43 & 1.79 & 88.66 & 0.56 & 0.49 & 0.06 \\
\hline 12.80 & 1.83 & 93.30 & 0.56 & 0.52 & 0.04 \\
\hline 13.40 & 1.91 & 81.78 & 0.56 & 0.46 & 0.10 \\
\hline 13.81 & 1.96 & 91.84 & 0.56 & 0.51 & 0.05 \\
\hline 13.93 & 1.97 & 94.59 & 0.56 & 0.53 & 0.03 \\
\hline 14.30 & 2.02 & 93.63 & 0.56 & 0.52 & 0.04 \\
\hline 14.90 & 2.09 & 96.00 & 0.56 & 0.53 & 0.02 \\
\hline 15.31 & 2.14 & 89.95 & 0.59 & 0.53 & 0.06 \\
\hline 15.43 & 2.15 & 80.86 & 0.59 & 0.47 & 0.11 \\
\hline 17.00 & 2.35 & 94.78 & 0.59 & 0.55 & 0.03 \\
\hline 17.41 & 2.40 & 89.96 & 0.59 & 0.53 & 0.06 \\
\hline 17.53 & 2.41 & 94.92 & 0.59 & 0.56 & 0.03 \\
\hline 17.90 & 2.46 & 92.41 & 0.59 & 0.54 & 0.04 \\
\hline 18.50 & 2.53 & 90.01 & 0.63 & 0.56 & 0.06 \\
\hline 18.91 & 2.58 & 88.12 & 0.63 & 0.55 & 0.07 \\
\hline 19.03 & 2.60 & 90.09 & 0.63 & 0.56 & 0.06 \\
\hline 19.40 & 2.64 & 93.94 & 0.63 & 0.59 & 0.04 \\
\hline 20.00 & 2.72 & 91.23 & 0.63 & 0.57 & 0.05 \\
\hline 20.90 & 2.83 & 94.77 & 0.63 & 0.59 & 0.03 \\
\hline 21.50 & 2.90 & 93.41 & 0.61 & 0.57 & 0.04 \\
\hline 21.91 & 2.95 & 92.93 & 0.61 & 0.57 & 0.04 \\
\hline 22.03 & 2.97 & 96.19 & 0.61 & 0.59 & 0.02 \\
\hline 26.00 & 3.46 & 91.50 & 0.61 & 0.56 & 0.05 \\
\hline 26.60 & 3.53 & 94.61 & 0.61 & 0.58 & 0.03 \\
\hline 27.01 & 3.57 & 92.86 & 1.29 & 1.20 & 0.09 \\
\hline 27.13 & 3.58 & 94.71 & 1.29 & 1.22 & 0.07 \\
\hline 27.50 & 3.60 & 93.45 & 1.29 & 1.21 & 0.08 \\
\hline 28.10 & 3.63 & 93.44 & 1.29 & 1.21 & 0.08 \\
\hline 28.51 & 3.66 & 91.21 & 1.29 & 1.18 & 0.11 \\
\hline 28.53 & 3.66 & 92.69 & 1.29 & 1.20 & 0.09 \\
\hline
\end{tabular}

APPENDIX A (Continued)

\begin{tabular}{|c|c|c|c|c|c|}
\hline $\begin{array}{l}\text { Depth } \\
\text { (mbsf) }\end{array}$ & $\begin{array}{l}\text { Age } \\
(\mathrm{Ma})\end{array}$ & $\begin{array}{c}\mathrm{CaCO}_{3} \\
(\%)\end{array}$ & $\begin{array}{l}\text { Bulk } \\
\text { MAR }\end{array}$ & $\begin{array}{l}\mathrm{CaCO}_{3} \\
\text { MAR }\end{array}$ & $\begin{array}{c}\text { Non- } \mathrm{CaCO}_{3} \\
\text { MAR }\end{array}$ \\
\hline \multicolumn{6}{|c|}{ Hole 707A (Cont.): } \\
\hline 29.00 & 3.69 & 91.98 & 1.29 & 1.19 & 0.10 \\
\hline 29.60 & 3.72 & 88.92 & 1.29 & 1.15 & 0.14 \\
\hline 30.01 & 3.74 & 91.03 & 1.29 & 1.18 & 0.12 \\
\hline 30.30 & 3.76 & 94.89 & 1.29 & 1.23 & 0.07 \\
\hline 30.50 & 3.77 & 98.74 & 1.29 & 1.27 & 0.02 \\
\hline 31.10 & 3.81 & 94.40 & 1.29 & 1.22 & 0.07 \\
\hline 31.51 & 3.83 & 89.05 & 1.29 & 1.15 & 0.14 \\
\hline 31.63 & 3.84 & 95.28 & 1.29 & 1.23 & 0.06 \\
\hline 32.00 & 3.86 & 95.87 & 1.29 & 1.24 & 0.05 \\
\hline 35.70 & 4.08 & 93.70 & 1.34 & 1.26 & 0.08 \\
\hline 36.30 & 4.11 & 92.82 & 1.34 & 1.25 & 0.10 \\
\hline 36.69 & 4.14 & 90.74 & 1.34 & 1.22 & 0.12 \\
\hline 36.83 & 4.14 & 90.23 & 1.34 & 1.21 & 0.13 \\
\hline 37.20 & 4.17 & 95.32 & 1.34 & 1.28 & 0.06 \\
\hline 37.80 & 4.20 & 87.93 & 1.34 & 1.18 & 0.16 \\
\hline 38.19 & 4.22 & 91.36 & 1.37 & 1.25 & 0.12 \\
\hline 38.33 & 4.23 & 90.62 & 1.37 & 1.24 & 0.13 \\
\hline 38.70 & 4.25 & 92.37 & 1.37 & 1.26 & 0.10 \\
\hline 39.30 & 4.29 & 92.46 & 1.37 & 1.26 & 0.10 \\
\hline 39.69 & 4.31 & 88.05 & 1.37 & 1.20 & 0.16 \\
\hline 39.83 & 4.32 & 94.17 & 1.37 & 1.29 & 0.08 \\
\hline 40.20 & 4.34 & 94.09 & 1.37 & 1.29 & 0.08 \\
\hline 40.80 & 4.38 & 93.88 & 1.45 & 1.36 & 0.09 \\
\hline 41.19 & 4.40 & 93.10 & 1.45 & 1.35 & 0.10 \\
\hline 41.33 & 4.41 & 94.23 & 1.45 & 1.37 & 0.08 \\
\hline 41.70 & 4.43 & 90.59 & 1.45 & 1.32 & 0.14 \\
\hline 42.30 & 4.46 & 94.07 & 1.45 & 1.37 & 0.09 \\
\hline 42.69 & 4.49 & 87.28 & 1.45 & 1.27 & 0.18 \\
\hline 42.83 & 4.49 & 94.67 & 1.45 & 1.38 & 0.08 \\
\hline 43.20 & 4.52 & 94.65 & 1.45 & 1.38 & 0.08 \\
\hline 45.30 & 4.64 & 92.78 & 1.47 & 1.36 & 0.11 \\
\hline 45.90 & 4.67 & 93.42 & 1.47 & 1.37 & 0.10 \\
\hline 46.29 & 4.70 & 85.37 & 1.47 & 1.26 & 0.22 \\
\hline 46.43 & 4.70 & 94.83 & 1.47 & 1.39 & 0.08 \\
\hline 46.80 & 4.73 & 93.00 & 1.47 & 1.37 & 0.10 \\
\hline 47.40 & 4.76 & 85.16 & 1.42 & 1.21 & 0.21 \\
\hline 47.79 & 4.78 & 90.69 & 1.42 & 1.29 & 0.13 \\
\hline 47.93 & 4.79 & 94.38 & 1.42 & 1.34 & 0.08 \\
\hline 48.30 & 4.81 & 85.17 & 1.42 & 1.21 & 0.21 \\
\hline 48.90 & 4.85 & 96.97 & 1.42 & 1.38 & 0.04 \\
\hline 49.29 & 4.87 & 90.65 & 1.42 & 1.29 & 0.13 \\
\hline 49.43 & 4.88 & 90.88 & 1.42 & 1.29 & 0.13 \\
\hline 49.80 & 4.90 & 89.93 & 1.42 & 1.28 & 0.14 \\
\hline 50.40 & 4.94 & 93.29 & 1.54 & 1.44 & 0.10 \\
\hline 50.79 & 4.96 & 91.40 & 1.54 & 1.41 & 0.13 \\
\hline 50.93 & 4.97 & 95.65 & 1.54 & 1.47 & 0.07 \\
\hline 51.30 & 4.99 & 95.30 & 1.54 & 1.47 & 0.07 \\
\hline 51.90 & 5.02 & 87.14 & 1.54 & 1.34 & 0.20 \\
\hline 52.29 & 5.05 & 89.78 & 1.54 & 1.38 & 0.16 \\
\hline 52.80 & 5.08 & 89.08 & 1.54 & 1.37 & 0.17 \\
\hline 53.40 & 5.11 & 95.70 & 1.54 & 1.47 & 0.07 \\
\hline 53.79 & 5.14 & 86.87 & 1.54 & 1.34 & 0.20 \\
\hline 53.93 & 5.14 & 90.42 & 1.54 & 1.39 & 0.15 \\
\hline 54.30 & 5.17 & 86.44 & 1.54 & 1.33 & 0.21 \\
\hline 54.90 & 5.20 & 93.88 & 1.63 & 1.53 & 0.10 \\
\hline 55.50 & 5.24 & 89.03 & 1.63 & 1.45 & 0.18 \\
\hline 55.89 & 5.26 & 90.50 & 1.63 & 1.48 & 0.16 \\
\hline 56.03 & 5.27 & 86.80 & 1.63 & 1.42 & 0.22 \\
\hline 56.40 & 5.29 & 94.31 & 1.63 & 1.54 & 0.09 \\
\hline 57.00 & 5.32 & 94.60 & 1.58 & 1.50 & 0.09 \\
\hline 57.39 & 5.35 & 88.61 & 1.58 & 1.40 & 0.18 \\
\hline 57.53 & 5.35 & 95.50 & 1.58 & 1.51 & 0.07 \\
\hline 57.90 & 5.38 & 90.06 & 1.58 & 1.42 & 0.16 \\
\hline 58.50 & 5.41 & 92.64 & 1.58 & 1.47 & 0.12 \\
\hline 59.03 & 5.44 & 91.06 & 1.58 & 1.44 & 0.14 \\
\hline 59.40 & 5.46 & 84.83 & 1.58 & 1.34 & 0.24 \\
\hline 60.00 & 5.50 & 94.12 & 1.46 & 1.38 & 0.09 \\
\hline 60.39 & 5.52 & 91.40 & 1.46 & 1.34 & 0.13 \\
\hline 60.53 & 5.53 & 93.90 & 1.46 & 1.37 & 0.09 \\
\hline 60.90 & 5.55 & 79.84 & 1.46 & 1.17 & 0.29 \\
\hline 61.50 & 5.59 & 91.94 & 1.46 & 1.34 & 0.12 \\
\hline 61.89 & 5.61 & 93.06 & 1.46 & 1.36 & 0.10 \\
\hline 62.40 & 5.64 & 94.69 & 1.46 & 1.38 & 0.08 \\
\hline 63.00 & 5.67 & 94.98 & 1.46 & 1.39 & 0.07 \\
\hline 63.39 & 5.70 & 94.15 & 1.34 & 1.26 & 0.08 \\
\hline 64.50 & 5.76 & 92.79 & 1.34 & 1.25 & 0.10 \\
\hline
\end{tabular}


APPENDIX A (Continued)

\begin{tabular}{|c|c|c|c|c|c|}
\hline $\begin{array}{l}\text { Depth } \\
\text { (mbsf) }\end{array}$ & $\begin{array}{l}\text { Age } \\
\text { (Ma) }\end{array}$ & $\begin{array}{c}\mathrm{CaCO}_{3} \\
(\%)\end{array}$ & $\begin{array}{l}\text { Bulk } \\
\text { MAR }\end{array}$ & $\begin{array}{c}\mathrm{CaCO}_{3} \\
\mathrm{MAR}\end{array}$ & $\begin{array}{c}\text { Non- } \mathrm{CaCO}_{3} \\
\text { MAR }\end{array}$ \\
\hline \multicolumn{6}{|c|}{ Hole 707A (Cont.): } \\
\hline 65.10 & 5.80 & 95.36 & 1.34 & 1.28 & 0.06 \\
\hline 65.49 & 5.82 & 90.57 & 1.34 & 1.22 & 0.13 \\
\hline 65.63 & 5.83 & 83.29 & 1.34 & 1.12 & 0.22 \\
\hline 66.00 & 5.85 & 93.20 & 1.34 & 1.25 & 0.09 \\
\hline 66.60 & 5.88 & 94.13 & 1.36 & 1.28 & 0.08 \\
\hline 66.99 & 5.91 & 92.97 & 1.36 & 1.26 & 0.10 \\
\hline 67.13 & 5.92 & 93.69 & 1.36 & 1.27 & 0.09 \\
\hline 67.50 & 5.94 & 85.92 & 1.36 & 1.17 & 0.19 \\
\hline 68.10 & 5.97 & 92.39 & 1.36 & 1.26 & 0.10 \\
\hline 68.49 & 5.99 & 91.98 & 1.36 & 1.25 & 0.11 \\
\hline 68.63 & 6.00 & 94.25 & 1.36 & 1.28 & 0.08 \\
\hline 69.00 & 6.02 & 95.82 & 1.36 & 1.30 & 0.06 \\
\hline 69.60 & 6.06 & 95.27 & 1.45 & 1.38 & 0.07 \\
\hline 69.99 & 6.08 & 87.93 & 1.45 & 1.27 & 0.17 \\
\hline 70.13 & 6.09 & 92.76 & 1.45 & 1.34 & 0.10 \\
\hline 70.50 & 6.11 & 91.56 & 1.45 & 1.32 & 0.12 \\
\hline 71.10 & 6.15 & 92.78 & 1.45 & 1.34 & 0.10 \\
\hline 71.49 & 6.17 & 93.66 & 1.45 & 1.35 & 0.09 \\
\hline 71.63 & 6.18 & 93.53 & 1.45 & 1.35 & 0.09 \\
\hline 72.00 & 6.20 & 94.44 & 1.45 & 1.36 & 0.08 \\
\hline 72.60 & 6.24 & 95.64 & 1.50 & 1.44 & 0.07 \\
\hline 72.99 & 6.26 & 93.25 & 1.50 & 1.40 & 0.10 \\
\hline 73.13 & 6.27 & 96.80 & 1.50 & 1.46 & 0.05 \\
\hline 73.50 & 6.29 & 93.82 & 1.50 & 1.41 & 0.09 \\
\hline 74.20 & 6.33 & 93.61 & 1.50 & 1.41 & 0.10 \\
\hline 74.80 & 6.36 & 94.50 & 1.50 & 1.42 & 0.08 \\
\hline 75.19 & 6.39 & 91.37 & 1.50 & 1.38 & 0.13 \\
\hline 75.33 & 6.39 & 94.86 & 1.50 & 1.43 & 0.08 \\
\hline 75.70 & 6.42 & 93.65 & 1.50 & 1.41 & 0.10 \\
\hline 76.30 & 6.45 & 94.98 & 1.50 & 1.43 & 0.08 \\
\hline 76.69 & 6.47 & 91.00 & 1.53 & 1.39 & 0.14 \\
\hline 76.83 & 6.48 & 92.98 & 1.53 & 1.42 & 0.11 \\
\hline 77.20 & 6.50 & 94.47 & 1.53 & 1.45 & 0.08 \\
\hline 77.80 & 6.54 & 96.42 & 1.53 & 1.48 & 0.05 \\
\hline 78.19 & 6.56 & 92.09 & 1.53 & 1.41 & 0.12 \\
\hline 78.33 & 6.57 & 94.61 & 1.53 & 1.45 & 0.08 \\
\hline 78.70 & 6.59 & 92.80 & 1.53 & 1.42 & 0.11 \\
\hline 79.30 & 6.63 & 92.81 & 1.50 & 1.40 & 0.11 \\
\hline 79.69 & 6.65 & 93.68 & 1.50 & 1.41 & 0.10 \\
\hline 79.83 & 6.66 & 92.80 & 1.50 & 1.40 & 0.11 \\
\hline 80.20 & 6.68 & 93.84 & 1.50 & 1.41 & 0.09 \\
\hline 80.80 & 6.72 & 94.55 & 1.07 & 1.01 & 0.06 \\
\hline 81.19 & 6.75 & 92.23 & 1.07 & 0.99 & 0.08 \\
\hline 81.33 & 6.76 & 94.72 & 1.07 & 1.01 & 0.06 \\
\hline 81.70 & 6.79 & 94.83 & 1.07 & 1.01 & 0.06 \\
\hline 82.30 & 6.84 & 91.87 & 1.10 & 1.01 & 0.09 \\
\hline 82.69 & 6.88 & 93.01 & 1.10 & 1.02 & 0.08 \\
\hline 82.83 & 6.89 & 93.82 & 1.10 & 1.03 & 0.07 \\
\hline 83.20 & 6.92 & 95.03 & 1.10 & 1.04 & 0.05 \\
\hline 83.80 & 6.97 & 93.90 & 1.10 & 1.03 & 0.07 \\
\hline 84.40 & 7.02 & 94.01 & 1.10 & 1.03 & 0.07 \\
\hline 84.79 & 7.05 & 91.59 & 1.10 & 1.01 & 0.09 \\
\hline 84.93 & 7.06 & 94.17 & 1.10 & 1.04 & 0.06 \\
\hline 85.30 & 7.09 & 95.32 & 1.10 & 1.05 & 0.05 \\
\hline 85.90 & 7.14 & 90.43 & 1.10 & 0.99 & 0.11 \\
\hline 86.29 & 7.17 & 91.97 & 1.13 & 1.04 & 0.09 \\
\hline 86.43 & 7.18 & 94.77 & 1.13 & 1.07 & 0.06 \\
\hline 86.80 & 7.21 & 92.10 & 1.13 & 1.04 & 0.09 \\
\hline 87.40 & 7.26 & 93.68 & 1.13 & 1.06 & 0.07 \\
\hline 87.79 & 7.30 & 91.90 & 1.13 & 1.04 & 0.09 \\
\hline 87.93 & 7.31 & 92.98 & 1.13 & 1.05 & 0.08 \\
\hline 88.30 & 7.34 & 88.81 & 1.13 & 1.00 & 0.13 \\
\hline 88.90 & 7.39 & 87.68 & 1.13 & 0.99 & 0.14 \\
\hline 89.29 & 7.42 & 92.03 & 1.09 & 1.01 & 0.09 \\
\hline 89.43 & 7.43 & 93.29 & 1.09 & 1.02 & 0.07 \\
\hline 89.80 & 7.46 & 92.34 & 1.09 & 1.01 & 0.08 \\
\hline 90.40 & 7.51 & 94.15 & 1.09 & 1.03 & 0.06 \\
\hline 90.79 & 7.54 & 91.84 & 1.09 & 1.00 & 0.09 \\
\hline 90.93 & 7.55 & 94.34 & 1.09 & 1.03 & 0.06 \\
\hline 91.30 & 7.58 & 89.16 & 1.09 & 0.97 & 0.12 \\
\hline 91.90 & 7.63 & 93.17 & 1.11 & 1.03 & 0.08 \\
\hline 91.91 & 7.63 & 92.12 & 1.11 & 1.02 & 0.09 \\
\hline 93.66 & 7.78 & 94.86 & 1.11 & 1.05 & 0.06 \\
\hline 103.00 & 8.55 & 95.94 & 1.11 & 1.06 & 0.04 \\
\hline 103.60 & 8.60 & 93.65 & 1.11 & 1.04 & 0.07 \\
\hline 103.99 & 8.63 & 92.12 & 1.11 & 1.02 & 0.09 \\
\hline
\end{tabular}

APPENDIX A (Continued)

\begin{tabular}{|c|c|c|c|c|c|}
\hline $\begin{array}{l}\text { Depth } \\
\text { (mbsf) }\end{array}$ & $\begin{array}{l}\text { Age } \\
(\mathrm{Ma})\end{array}$ & $\begin{array}{c}\mathrm{CaCO}_{3} \\
(\%)\end{array}$ & $\begin{array}{l}\text { Bulk } \\
\text { MAR }\end{array}$ & $\begin{array}{c}\mathrm{CaCO}_{3} \\
\mathrm{MAR}\end{array}$ & $\begin{array}{c}\text { Non- } \mathrm{CaCO}_{3} \\
\text { MAR }\end{array}$ \\
\hline \multicolumn{6}{|c|}{ Hole 707A (Cont.): } \\
\hline 104.13 & 8.64 & 92.08 & 1.11 & 1.02 & 0.09 \\
\hline 104.50 & 8.67 & 94.08 & 1.11 & 1.04 & 0.07 \\
\hline 105.10 & 8.75 & 93.40 & 0.43 & 0.40 & 0.03 \\
\hline 105.49 & 8.83 & 91.23 & 0.43 & 0.39 & 0.04 \\
\hline 105.63 & 8.86 & 95.82 & 0.43 & 0.41 & 0.02 \\
\hline 106.00 & 8.94 & 95.32 & 0.43 & 0.41 & 0.02 \\
\hline 106.60 & 9.07 & 91.25 & 0.43 & 0.39 & 0.04 \\
\hline 106.99 & 9.15 & 88.62 & 0.43 & 0.38 & 0.05 \\
\hline 107.13 & 9.18 & 95.75 & 0.43 & 0.41 & 0.02 \\
\hline 107.50 & 9.26 & 95.10 & 0.43 & 0.41 & 0.02 \\
\hline 108.10 & 9.38 & 86.24 & 0.43 & 0.37 & 0.06 \\
\hline 108.40 & 9.45 & 94.48 & 0.45 & 0.42 & 0.02 \\
\hline 108.49 & 9.47 & 92.58 & 0.45 & 0.42 & 0.03 \\
\hline 109.00 & 9.57 & 94.69 & 0.45 & 0.43 & 0.02 \\
\hline 109.60 & 9.70 & 93.16 & 0.45 & 0.42 & 0.03 \\
\hline 109.99 & 9.78 & 91.99 & 0.45 & 0.41 & 0.04 \\
\hline 110.13 & 9.81 & 95.87 & 0.45 & 0.43 & 0.02 \\
\hline 110.50 & 9.89 & 95.47 & 0.45 & 0.43 & 0.02 \\
\hline 111.10 & 10.02 & 76.75 & 0.44 & 0.34 & 0.10 \\
\hline 111.40 & 10.08 & 95.57 & 0.44 & 0.42 & 0.02 \\
\hline 111.45 & 10.09 & 90.88 & 0.44 & 0.40 & 0.04 \\
\hline 112.60 & 10.33 & 94.99 & 0.44 & 0.42 & 0.02 \\
\hline 113.59 & 10.54 & 94.66 & 0.44 & 0.41 & 0.02 \\
\hline 113.73 & 10.57 & 94.65 & 0.44 & 0.41 & 0.02 \\
\hline 114.10 & 10.65 & 94.99 & 0.44 & 0.42 & 0.02 \\
\hline 114.70 & 10.77 & 94.68 & 0.41 & 0.39 & 0.02 \\
\hline 115.09 & 10.86 & 91.77 & 0.41 & 0.38 & 0.03 \\
\hline 115.23 & 10.89 & 91.83 & 0.41 & 0.38 & 0.03 \\
\hline 115.60 & 10.96 & 96.68 & 0.41 & 0.40 & 0.01 \\
\hline 116.20 & 11.09 & 94.35 & 0.41 & 0.39 & 0.02 \\
\hline 116.59 & 11.23 & 90.85 & 0.22 & 0.20 & 0.02 \\
\hline 116.73 & 11.29 & 85.73 & 0.22 & 0.19 & 0.03 \\
\hline 117.10 & 11.43 & 95.00 & 0.22 & 0.21 & 0.01 \\
\hline 117.70 & 11.67 & 97.06 & 0.22 & 0.21 & 0.01 \\
\hline 118.09 & 11.82 & 92.30 & 0.22 & 0.20 & 0.02 \\
\hline 118.23 & 11.87 & 93.50 & 0.22 & 0.20 & 0.01 \\
\hline 118.60 & 12.02 & 96.03 & 0.22 & 0.21 & 0.01 \\
\hline 119.20 & 12.25 & 96.15 & 0.22 & 0.21 & 0.01 \\
\hline 119.59 & 12.40 & 94.54 & 0.22 & 0.20 & 0.01 \\
\hline 122.20 & 13.42 & 94.77 & 0.22 & 0.20 & 0.01 \\
\hline 122.80 & 13.67 & 95.15 & 0.19 & 0.18 & 0.01 \\
\hline 123.19 & 13.84 & 92.85 & 0.19 & 0.18 & 0.01 \\
\hline 123.33 & 13.90 & 94.39 & 0.19 & 0.18 & 0.01 \\
\hline 123.70 & 14.06 & 95.23 & 0.19 & 0.18 & 0.01 \\
\hline 124.30 & 14.32 & 89.64 & 0.18 & 0.16 & 0.02 \\
\hline 124.69 & 14.49 & 92.28 & 0.18 & 0.17 & 0.01 \\
\hline 124.83 & 14.55 & 95.32 & 0.18 & 0.17 & 0.01 \\
\hline 125.80 & 14.97 & 93.41 & 0.18 & 0.17 & 0.01 \\
\hline 125.80 & 14.97 & 95.11 & 0.18 & 0.17 & 0.01 \\
\hline 126.19 & 15.14 & 90.82 & 0.18 & 0.16 & 0.02 \\
\hline 126.33 & 15.21 & 87.55 & 0.18 & 0.16 & 0.02 \\
\hline 126.70 & 15.37 & 94.75 & 0.18 & 0.17 & 0.01 \\
\hline 127.30 & 15.63 & 86.52 & 0.17 & 0.14 & 0.02 \\
\hline 127.69 & 15.80 & 92.31 & 0.17 & 0.15 & 0.01 \\
\hline 127.83 & 15.86 & 95.50 & 0.17 & 0.16 & 0.01 \\
\hline 128.20 & 16.02 & 81.62 & 0.17 & 0.13 & 0.03 \\
\hline 128.60 & 16.20 & 92.85 & 0.17 & 0.15 & 0.01 \\
\hline 131.80 & 17.59 & 93.50 & 0.17 & 0.15 & 0.01 \\
\hline 132.40 & 17.85 & 95.34 & 0.17 & 0.16 & 0.01 \\
\hline 132.79 & 18.02 & 87.84 & 0.17 & 0.14 & 0.02 \\
\hline 132.93 & 18.09 & 91.26 & 0.17 & 0.15 & 0.01 \\
\hline 133.30 & 18.25 & 94.61 & 0.17 & 0.16 & 0.01 \\
\hline 133.90 & 18.62 & 95.34 & 0.08 & 0.08 & 0.00 \\
\hline 134.29 & 18.95 & 87.32 & 0.08 & 0.07 & 0.01 \\
\hline 134.43 & 19.08 & 90.26 & 0.08 & 0.07 & 0.01 \\
\hline 134.80 & 19.40 & 92.74 & 0.08 & 0.07 & 0.01 \\
\hline 135.40 & 19.92 & 93.76 & 0.08 & 0.08 & 0.01 \\
\hline 135.79 & 20.25 & 92.23 & 0.08 & 0.07 & 0.01 \\
\hline 136.30 & 20.70 & 96.92 & 0.08 & 0.08 & 0.00 \\
\hline 136.90 & 21.22 & 89.87 & 0.10 & 0.09 & 0.01 \\
\hline 137.29 & 21.55 & 92.15 & 0.10 & 0.09 & 0.01 \\
\hline 137.43 & 21.67 & 94.55 & 0.10 & 0.09 & 0.01 \\
\hline 137.80 & 21.99 & 92.72 & 0.10 & 0.09 & 0.01 \\
\hline 138.40 & 22.51 & 94.89 & 0.10 & 0.09 & 0.01 \\
\hline 138.79 & 22.85 & 90.18 & 0.10 & 0.09 & 0.01 \\
\hline 138.93 & 22.97 & 94.16 & 0.10 & 0.09 & 0.01 \\
\hline
\end{tabular}


APPENDIX A (Continued)

\begin{tabular}{|c|c|c|c|c|c|}
\hline $\begin{array}{l}\text { Depth } \\
\text { (mbsf) }\end{array}$ & $\begin{array}{l}\text { Age } \\
(\mathrm{Ma})\end{array}$ & $\begin{array}{c}\mathrm{CaCO}_{3} \\
(\%)\end{array}$ & $\begin{array}{l}\text { Bulk } \\
\text { MAR }\end{array}$ & $\begin{array}{c}\mathrm{CaCO}_{3} \\
\mathrm{MAR}\end{array}$ & $\begin{array}{c}\text { Non- } \mathrm{CaCO}_{3} \\
\text { MAR }\end{array}$ \\
\hline \multicolumn{6}{|c|}{ Hole 707A (Cont.): } \\
\hline 139.30 & 23.29 & 93.71 & 0.10 & 0.09 & 0.01 \\
\hline 139.73 & 23.67 & 93.50 & 0.10 & 0.09 & 0.01 \\
\hline 141.50 & 25.20 & 96.86 & 0.10 & 0.10 & 0.00 \\
\hline 142.10 & 25.32 & 94.72 & 0.45 & 0.42 & 0.02 \\
\hline 142.49 & 25.39 & 93.35 & 0.45 & 0.42 & 0.03 \\
\hline 142.63 & 25.42 & 97.12 & 0.45 & 0.43 & 0.01 \\
\hline 143.00 & 25.49 & 96.71 & 0.45 & 0.43 & 0.01 \\
\hline 143.60 & 25.61 & 96.90 & 0.52 & 0.50 & 0.02 \\
\hline 143.99 & 25.68 & 93.06 & 0.52 & 0.48 & 0.04 \\
\hline 144.13 & 25.71 & 96.56 & 0.52 & 0.50 & 0.02 \\
\hline 144.50 & 25.78 & 96.04 & 0.52 & 0.50 & 0.02 \\
\hline 145.10 & 25.90 & 96.04 & 0.52 & 0.50 & 0.02 \\
\hline 145.49 & 25.97 & 92.84 & 0.52 & 0.48 & 0.04 \\
\hline 145.63 & 26.00 & 96.85 & 0.52 & 0.50 & 0.02 \\
\hline 146.00 & 26.07 & 91.91 & 0.52 & 0.47 & 0.04 \\
\hline 146.60 & 26.19 & 95.08 & 0.52 & 0.49 & 0.03 \\
\hline 146.99 & 26.26 & 92.88 & 0.52 & 0.48 & 0.04 \\
\hline 147.13 & 26.29 & 95.68 & 0.52 & 0.49 & 0.02 \\
\hline 147.50 & 26.36 & 95.29 & 0.52 & 0.49 & 0.02 \\
\hline 148.10 & 26.48 & 93.20 & 0.52 & 0.48 & 0.04 \\
\hline 148.49 & 26.55 & 88.91 & 0.49 & 0.44 & 0.05 \\
\hline 148.63 & 26.58 & 93.56 & 0.49 & 0.46 & 0.03 \\
\hline 149.00 & 26.65 & 94.17 & 0.49 & 0.46 & 0.03 \\
\hline 149.60 & 26.77 & 94.52 & 0.49 & 0.46 & 0.03 \\
\hline 149.99 & 26.85 & 92.32 & 0.49 & 0.45 & 0.04 \\
\hline 150.13 & 26.87 & 93.51 & 0.49 & 0.46 & 0.03 \\
\hline 150.50 & 26.94 & 94.32 & 0.49 & 0.46 & 0.03 \\
\hline 151.10 & 27.06 & 95.06 & 0.49 & 0.47 & 0.02 \\
\hline 151.20 & 27.08 & 95.70 & 0.49 & 0.47 & 0.02 \\
\hline 151.80 & 27.20 & 94.51 & 0.49 & 0.46 & 0.03 \\
\hline 152.30 & 27.29 & 80.04 & 0.49 & 0.39 & 0.10 \\
\hline 173.90 & 31.48 & 93.58 & 0.51 & 0.48 & 0.03 \\
\hline 174.50 & 31.59 & 94.06 & 0.51 & 0.48 & 0.03 \\
\hline 174.89 & 31.67 & 92.86 & 0.51 & 0.47 & 0.04 \\
\hline 175.03 & 31.70 & 94.33 & 0.51 & 0.48 & 0.03 \\
\hline 175.40 & 31.77 & 94.90 & 0.51 & 0.48 & 0.03 \\
\hline 176.00 & 31.88 & 93.39 & 0.51 & 0.47 & 0.03 \\
\hline 176.39 & 31.96 & 87.93 & 0.51 & 0.45 & 0.06 \\
\hline 176.90 & 32.06 & 94.36 & 0.51 & 0.48 & 0.03 \\
\hline 177.50 & 32.18 & 92.31 & 0.51 & 0.47 & 0.04 \\
\hline 177.89 & 32.25 & 90.93 & 0.51 & 0.46 & 0.05 \\
\hline 178.03 & 32.28 & 94.50 & 0.51 & 0.48 & 0.03 \\
\hline 183.60 & 33.36 & 94.03 & 0.56 & 0.53 & 0.03 \\
\hline 184.20 & 33.47 & 94.59 & 0.56 & 0.53 & 0.03 \\
\hline 184.59 & 33.55 & 92.11 & 0.56 & 0.52 & 0.04 \\
\hline 184.73 & 33.58 & 93.77 & 0.56 & 0.53 & 0.03 \\
\hline 185.10 & 33.65 & 94.82 & 0.56 & 0.53 & 0.03 \\
\hline 185.70 & 33.76 & 93.78 & 0.56 & 0.53 & 0.03 \\
\hline 186.09 & 33.84 & 92.69 & 0.56 & 0.52 & 0.04 \\
\hline 186.23 & 33.87 & 93.62 & 0.56 & 0.52 & 0.04 \\
\hline 186.60 & 33.94 & 93.63 & 0.56 & 0.52 & 0.04 \\
\hline 187.20 & 34.05 & 94.57 & 0.56 & 0.53 & 0.03 \\
\hline 187.59 & 34.13 & 93.91 & 0.56 & 0.53 & 0.03 \\
\hline 187.73 & 34.16 & 94.25 & 0.56 & 0.53 & 0.03 \\
\hline 188.10 & 34.23 & 94.31 & 0.56 & 0.53 & 0.03 \\
\hline 188.70 & 34.35 & 92.97 & 0.56 & 0.52 & 0.04 \\
\hline 189.09 & 34.42 & 91.90 & 0.56 & 0.51 & 0.05 \\
\hline 189.23 & 34.45 & 92.88 & 0.56 & 0.52 & 0.04 \\
\hline 189.60 & 34.52 & 90.16 & 0.59 & 0.53 & 0.06 \\
\hline 190.20 & 34.64 & 95.22 & 0.59 & 0.56 & 0.03 \\
\hline 190.73 & 34.74 & 95.00 & 0.59 & 0.56 & 0.03 \\
\hline 191.10 & 34.81 & 94.97 & 0.59 & 0.56 & 0.03 \\
\hline 191.70 & 34.93 & 95.66 & 0.59 & 0.56 & 0.03 \\
\hline 192.20 & 35.02 & 95.31 & 0.59 & 0.56 & 0.03 \\
\hline 193.30 & 35.24 & 92.81 & 0.59 & 0.54 & 0.04 \\
\hline 193.90 & 35.35 & 92.66 & 0.59 & 0.54 & 0.04 \\
\hline 194.43 & 35.46 & 94.05 & 0.59 & 0.55 & 0.03 \\
\hline 194.80 & 35.53 & 93.04 & 0.59 & 0.55 & 0.04 \\
\hline 195.40 & 35.64 & 92.46 & 0.59 & 0.54 & 0.04 \\
\hline 195.93 & 35.75 & 93.20 & 0.59 & 0.55 & 0.04 \\
\hline 196.30 & 35.82 & 92.98 & 0.59 & 0.54 & 0.04 \\
\hline 196.90 & 35.93 & 93.36 & 0.59 & 0.55 & 0.04 \\
\hline 197.43 & 36.04 & 94.77 & 0.59 & 0.56 & 0.03 \\
\hline 197.80 & 36.11 & 95.05 & 0.57 & 0.54 & 0.03 \\
\hline 198.40 & 36.22 & 92.37 & 0.57 & 0.52 & 0.04 \\
\hline 198.93 & 36.33 & 93.38 & 0.57 & 0.53 & 0.04 \\
\hline
\end{tabular}

APPENDIX A (Continued)

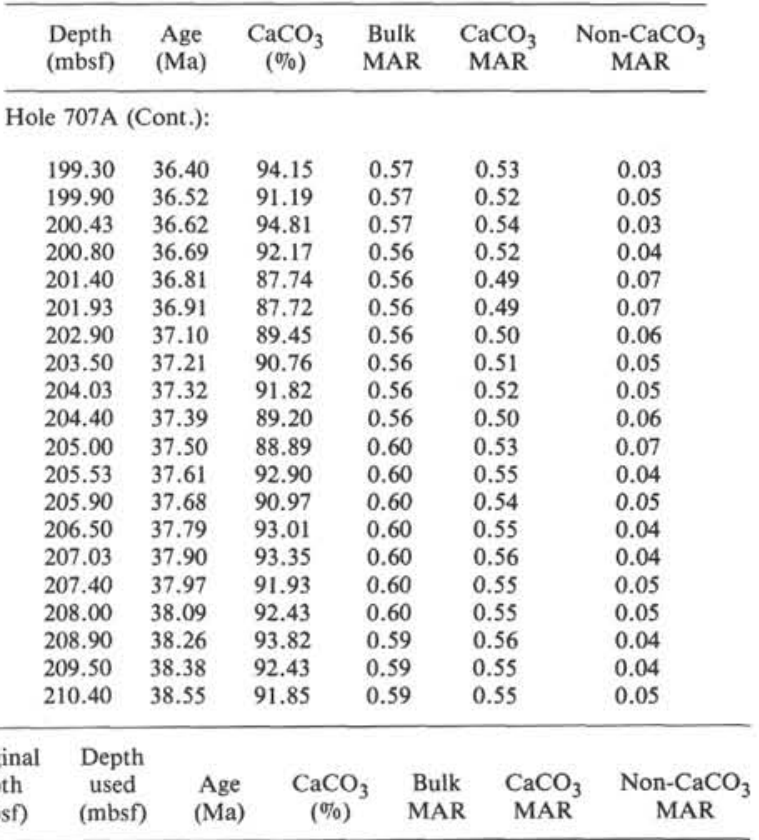

Hole 708A:

\begin{tabular}{|c|c|c|c|c|c|c|}
\hline 2.61 & 0.61 & 0.097 & 71.95 & 0.35 & 0.25 & 0.10 \\
\hline 2.62 & 0.62 & 0.098 & 71.91 & 0.35 & 0.25 & 0.10 \\
\hline 3.32 & 1.32 & 0.209 & 78.53 & 0.35 & 0.27 & 0.07 \\
\hline 4.11 & 2.11 & 0.335 & 81.53 & 0.35 & 0.28 & 0.06 \\
\hline 4.12 & 2.12 & 0.336 & 77.64 & 0.35 & 0.27 & 0.08 \\
\hline 4.82 & 2.82 & 0.447 & 64.56 & 0.35 & 0.22 & 0.12 \\
\hline 5.08 & 3.08 & 0.473 & 76.35 & 0.77 & 0.59 & 0.18 \\
\hline 5.61 & 3.61 & 0.511 & 41.43 & 0.88 & 0.36 & 0.51 \\
\hline 5.62 & 3.62 & 0.511 & 44.88 & 0.88 & 0.39 & 0.48 \\
\hline 8.36 & 4.16 & 0.550 & 71.18 & 0.98 & 0.70 & 0.28 \\
\hline 8.62 & 4.42 & 0.568 & 70.58 & 1.01 & 0.71 & 0.30 \\
\hline 10.11 & 4.91 & 0.603 & 81.06 & 1.01 & 0.82 & 0.19 \\
\hline 10.12 & 4.92 & 0.604 & 81.60 & 1.01 & 0.82 & 0.19 \\
\hline 10.82 & 5.62 & 0.654 & 68.29 & 1.01 & 0.69 & 0.32 \\
\hline 11.59 & 6.39 & 0.709 & 77.77 & 1.04 & 0.81 & 0.23 \\
\hline 11.61 & 6.41 & 0.710 & 76.60 & 0.93 & 0.71 & 0.22 \\
\hline 11.62 & 6.42 & 0.711 & 74.33 & 0.93 & 0.69 & 0.24 \\
\hline 13.11 & 6.91 & 0.746 & 63.57 & 0.93 & 0.59 & 0.34 \\
\hline 13.12 & 6.92 & 0.746 & 65.84 & 0.93 & 0.61 & 0.32 \\
\hline 15.32 & 8.62 & 0.867 & 59.79 & 0.93 & 0.55 & 0.37 \\
\hline 15.35 & 8.65 & 0.870 & 53.71 & 0.81 & 0.44 & 0.38 \\
\hline 16.11 & 9.41 & 0.924 & 60.83 & 1.06 & 0.64 & 0.42 \\
\hline 16.12 & 9.42 & 0.924 & 54.65 & 1.06 & 0.58 & 0.48 \\
\hline 16.82 & 10.12 & 0.974 & 74.51 & 1.06 & 0.79 & 0.27 \\
\hline 17.61 & 10.91 & 1.030 & 83.94 & 1.06 & 0.89 & 0.17 \\
\hline 17.62 & 10.92 & 1.031 & 81.87 & 1.06 & 0.87 & 0.19 \\
\hline 17.74 & 11.04 & 1.040 & 84.70 & 1.31 & 1.11 & 0.20 \\
\hline 25.26 & 14.06 & 1.255 & 85.65 & 1.24 & 1.06 & 0.18 \\
\hline 25.75 & 14.55 & 1.290 & 82.43 & 1.17 & 0.97 & 0.21 \\
\hline 26.43 & 15.23 & 1.338 & 78.71 & 1.10 & 0.86 & 0.23 \\
\hline 30.71 & 18.01 & 1.558 & 70.12 & 0.92 & 0.64 & 0.27 \\
\hline 30.72 & 18.02 & 1.558 & 69.51 & 0.92 & 0.64 & 0.28 \\
\hline 31.42 & 18.72 & 1.621 & 67.70 & 0.92 & 0.62 & 0.30 \\
\hline 32.21 & 19.51 & 1.691 & 81.69 & 0.92 & 0.75 & 0.17 \\
\hline 32.22 & 19.52 & 1.692 & 88.40 & 0.92 & 0.81 & 0.11 \\
\hline 34.42 & 20.22 & 1.754 & 84.26 & 0.92 & 0.77 & 0.14 \\
\hline 35.21 & 21.01 & 1.824 & 81.14 & 0.92 & 0.74 & 0.17 \\
\hline 35.22 & 21.02 & 1.825 & 75.91 & 0.92 & 0.70 & 0.22 \\
\hline 35.92 & 21.72 & 1.887 & 72.54 & 0.92 & 0.67 & 0.25 \\
\hline 36.71 & 22.51 & 1.958 & 81.22 & 0.92 & 0.74 & 0.17 \\
\hline 36.72 & 22.52 & 1.958 & 80.26 & 0.92 & 0.74 & 0.18 \\
\hline 37.42 & 23.22 & 2.021 & 70.68 & 0.92 & 0.65 & 0.27 \\
\hline 38.37 & 23.47 & 2.043 & 81.64 & 0.92 & 0.75 & 0.17 \\
\hline 38.95 & 24.05 & 2.094 & 81.19 & 0.92 & 0.74 & 0.17 \\
\hline 39.35 & 24.45 & 2.130 & 79.38 & 0.92 & 0.73 & 0.19 \\
\hline 39.49 & 24.59 & 2.142 & 79.41 & 0.96 & 0.76 & 0.20 \\
\hline 39.87 & 24.97 & 2.176 & 77.15 & 0.88 & 0.68 & 0.20 \\
\hline 40.85 & 25.95 & 2.263 & 64.70 & 0.88 & 0.57 & 0.31 \\
\hline 41.37 & 26.47 & 2.310 & 74.79 & 0.88 & 0.66 & 0.22 \\
\hline
\end{tabular}


APPENDIX A (Continued)

\begin{tabular}{|c|c|c|c|c|c|c|}
\hline $\begin{array}{l}\text { Original } \\
\text { depth } \\
\text { (mbsf) }\end{array}$ & $\begin{array}{l}\text { Depth } \\
\text { used } \\
\text { (mbsf) }\end{array}$ & $\begin{array}{l}\text { Age } \\
\text { (Ma) }\end{array}$ & $\begin{array}{c}\mathrm{CaCO}_{3} \\
(\%)\end{array}$ & $\begin{array}{l}\text { Bulk } \\
\text { MAR }\end{array}$ & $\begin{array}{c}\mathrm{CaCO}_{3} \\
\mathrm{MAR}\end{array}$ & $\begin{array}{c}\text { Non- } \mathrm{CaCO} \\
\text { MAR }\end{array}$ \\
\hline \multicolumn{7}{|c|}{ Hole 708A (Cont.): } \\
\hline 42.35 & 27.05 & 2.361 & 79.93 & 0.88 & 0.71 & 0.18 \\
\hline 42.87 & 27.57 & 2.407 & 63.02 & 0.88 & 0.56 & 0.33 \\
\hline 43.01 & 27.71 & 2.420 & 66.65 & 0.81 & 0.54 & 0.27 \\
\hline 43.45 & 28.15 & 2.459 & 72.85 & 0.79 & 0.58 & 0.22 \\
\hline 45.87 & 28.97 & 2.532 & 72.54 & 0.79 & 0.58 & 0.22 \\
\hline 46.45 & 29.55 & 2.583 & 66.74 & 0.79 & 0.53 & 0.26 \\
\hline 46.54 & 29.64 & 2.591 & 50.83 & 0.78 & 0.39 & 0.38 \\
\hline 48.97 & 30.27 & 2.647 & 68.71 & 0.79 & 0.54 & 0.25 \\
\hline 49.47 & 30.77 & 2.728 & 75.60 & 0.42 & 0.32 & 0.10 \\
\hline 50.06 & 31.36 & 2.825 & 63.29 & 0.42 & 0.27 & 0.16 \\
\hline 50.45 & 31.75 & 2.890 & 65.27 & 0.42 & 0.28 & 0.15 \\
\hline 50.47 & 31.77 & 2.893 & 66.31 & 0.43 & 0.28 & 0.14 \\
\hline 50.85 & 32.15 & 2.956 & 67.05 & 0.42 & 0.28 & 0.14 \\
\hline 50.90 & 32.20 & 2.964 & 59.90 & 0.42 & 0.25 & 0.17 \\
\hline 52.35 & 32.65 & 3.039 & 58.27 & 0.42 & 0.24 & 0.18 \\
\hline 52.37 & 32.67 & 3.042 & 57.63 & 0.41 & 0.24 & 0.17 \\
\hline 52.87 & 33.17 & 3.125 & 51.27 & 0.39 & 0.20 & 0.19 \\
\hline 53.23 & 33.53 & 3.184 & 46.40 & 0.39 & 0.18 & 0.21 \\
\hline 54.20 & 34.50 & 3.345 & 61.94 & 0.39 & 0.24 & 0.15 \\
\hline 55.37 & 35.27 & 3.472 & 61.84 & 0.39 & 0.24 & 0.15 \\
\hline 55.59 & 35.49 & 3.509 & 56.77 & 0.37 & 0.21 & 0.16 \\
\hline 55.77 & 35.67 & 3.538 & 69.92 & 0.38 & 0.27 & 0.12 \\
\hline 58.90 & 36.50 & 3.626 & 50.25 & 0.67 & 0.34 & 0.33 \\
\hline 59.01 & 36.61 & 3.637 & 45.09 & 0.69 & 0.31 & 0.38 \\
\hline 59.09 & 36.70 & 3.645 & 42.79 & 0.71 & 0.30 & 0.40 \\
\hline 59.47 & 37.07 & 3.680 & 47.99 & 0.71 & 0.34 & 0.37 \\
\hline 60.59 & 38.19 & 3.786 & 63.56 & 0.71 & 0.45 & 0.26 \\
\hline 60.76 & 38.36 & 3.803 & 61.44 & 0.73 & 0.45 & 0.28 \\
\hline 61.17 & 38.77 & 3.841 & 61.69 & 0.75 & 0.46 & 0.29 \\
\hline 61.45 & 39.05 & 3.868 & 62.17 & 0.77 & 0.48 & 0.29 \\
\hline 61.56 & 39.16 & 3.878 & 64.13 & 0.75 & 0.48 & 0.27 \\
\hline 62.01 & 39.61 & 3.921 & 67.28 & 0.75 & 0.51 & 0.25 \\
\hline 63.55 & 40.45 & 4.001 & 60.70 & 0.75 & 0.46 & 0.30 \\
\hline 64.55 & 41.45 & 4.095 & 63.46 & 0.75 & 0.48 & 0.28 \\
\hline 64.75 & 41.65 & 4.114 & 63.46 & 0.74 & 0.47 & 0.27 \\
\hline 65.09 & 41.99 & 4.146 & 74.77 & 0.71 & 0.53 & 0.18 \\
\hline 65.65 & 42.55 & 4.199 & 68.94 & 0.71 & 0.49 & 0.22 \\
\hline 66.01 & 42.91 & 4.234 & 68.26 & 0.71 & 0.49 & 0.23 \\
\hline 66.30 & 43.20 & 4.261 & 79.91 & 0.71 & 0.57 & 0.14 \\
\hline 67.75 & 44.65 & 4.398 & 69.71 & 0.71 & 0.50 & 0.22 \\
\hline 68.67 & 45.57 & 4.486 & 62.17 & 0.71 & 0.44 & 0.27 \\
\hline 68.74 & 45.64 & 4.492 & 64.96 & 0.69 & 0.45 & 0.24 \\
\hline 69.25 & 46.15 & 4.541 & 71.91 & 0.71 & 0.51 & 0.20 \\
\hline 69.65 & 46.55 & 4.578 & 72.17 & 0.71 & 0.51 & 0.20 \\
\hline 70.17 & 47.07 & 4.628 & 78.20 & 0.71 & 0.55 & 0.15 \\
\hline 71.15 & 48.05 & 4.721 & 62.72 & 0.71 & 0.44 & 0.26 \\
\hline 73.17 & 48.07 & 4.722 & 67.26 & 0.71 & 0,48 & 0.23 \\
\hline 74.15 & 48.55 & 4.768 & 72.17 & 0.71 & 0.51 & 0.20 \\
\hline 74.80 & 49.20 & 4.829 & 64.63 & 0.73 & 0.47 & 0.26 \\
\hline 75.25 & 49.65 & 4.872 & 51.67 & 0.67 & 0.35 & 0.32 \\
\hline 79.02 & 53.42 & 5.229 & 53.75 & 0.67 & 0.36 & 0.31 \\
\hline 84.37 & 58.77 & 5.736 & 66.29 & 0.67 & 0.44 & 0.23 \\
\hline 84.43 & 58.83 & 5.742 & 54.53 & 0.61 & 0.33 & 0.28 \\
\hline 104.27 & 74.97 & 6.767 & 80.98 & 0.62 & 0.50 & 0.12 \\
\hline 105.17 & 75.87 & 6.896 & 77.47 & 0.66 & 0.51 & 0.15 \\
\hline 106.82 & 77.52 & 7.131 & 88.73 & 0.71 & 0.63 & 0.08 \\
\hline 111.22 & 81.42 & 7.689 & 71.25 & 0.57 & 0.41 & 0.16 \\
\hline 112.72 & 82.92 & 7.903 & 56.25 & 0.43 & 0.24 & 0.19 \\
\hline 114.16 & 83.86 & 8.037 & 65.07 & 0.51 & 0.33 & 0.18 \\
\hline 116.76 & 86.46 & 8.409 & 62.35 & 0.60 & 0.37 & 0.22 \\
\hline 117.11 & 86.81 & 8.459 & 65.88 & 0.50 & 0.33 & 0.17 \\
\hline 120.85 & 90.05 & 9.224 & 37.15 & 0.21 & 0.08 & 0.13 \\
\hline 121.95 & 91.15 & 9.596 & 28.15 & 0.21 & 0.06 & 0.15 \\
\hline 122.98 & 92.18 & 9.944 & 35.26 & 0.17 & 0.06 & 0.11 \\
\hline 124.12 & 92.32 & 9.991 & 1.24 & 0.17 & 0.00 & 0.17 \\
\hline 124.37 & 92.57 & 10.076 & 23.81 & 0.17 & 0.04 & 0.13 \\
\hline 125.35 & 93.55 & 10.407 & 62.11 & 0.17 & 0.10 & 0.06 \\
\hline 126.22 & 94.42 & 10.701 & 54.03 & 0.17 & 0.09 & 0.08 \\
\hline 127.13 & 94.83 & 10.840 & 49.62 & 0.17 & 0.08 & 0.08 \\
\hline 127.45 & 95.15 & 10.948 & 18.28 & 0.16 & 0.03 & 0.13 \\
\hline 127.95 & 95.65 & 11.130 & 55.29 & 0.12 & 0.07 & 0.06 \\
\hline 129.55 & 96.05 & 11.369 & 0.70 & 0.12 & 0.00 & 0.12 \\
\hline 130.55 & 97.05 & 11.968 & 22.48 & 0.12 & 0.03 & 0.10 \\
\hline 131.65 & 98.15 & 12.626 & 50.23 & 0.12 & 0.06 & 0.06 \\
\hline
\end{tabular}

APPENDIX A (Continued)

\begin{tabular}{ccccccc}
\hline $\begin{array}{c}\text { Original } \\
\text { depth } \\
\text { (mbsf) }\end{array}$ & $\begin{array}{c}\text { Depth } \\
\text { used } \\
\text { (mbsf) }\end{array}$ & $\begin{array}{c}\text { Age } \\
(\mathrm{Ma})\end{array}$ & $\begin{array}{c}\mathrm{CaCO}_{3} \\
(\%)\end{array}$ & $\begin{array}{c}\text { Bulk } \\
\text { MAR }\end{array}$ & $\begin{array}{c}\mathrm{CaCO}_{3} \\
\mathrm{MAR}\end{array}$ & $\begin{array}{c}\mathrm{Non}-\mathrm{CaCO}_{3} \\
\text { MAR }\end{array}$ \\
\hline
\end{tabular}

Hole 708A (Cont.):

\begin{tabular}{|c|c|c|c|c|c|c|}
\hline 133.15 & 98.85 & 13.045 & 7.58 & 0.12 & 0.01 & 0.11 \\
\hline 133.55 & 99.10 & 13.194 & 51.80 & 0.12 & 0.06 & 0.06 \\
\hline 134.67 & 99.92 & 13.685 & 81.45 & 0.12 & 0.10 & 0.02 \\
\hline 135.29 & 100.54 & 14.056 & 56.14 & 0.12 & 0.07 & 0.05 \\
\hline 135.90 & 100.85 & 14.241 & 78.48 & 0.12 & 0.10 & 0.03 \\
\hline 136.55 & 101.50 & 14.630 & 70.70 & 0.12 & 0.09 & 0.04 \\
\hline 136.88 & 101.83 & 14.828 & 41.77 & 0.16 & 0.06 & 0.09 \\
\hline 137.66 & 102.31 & 15.115 & 80.86 & 0.15 & 0.12 & 0.03 \\
\hline 140.00 & 104.00 & 16.126 & 76.71 & 0.15 & 0.12 & 0.04 \\
\hline 141.00 & 105.00 & 16.725 & 81.42 & 0.15 & 0.12 & 0.03 \\
\hline 146.53 & 106.73 & 17.760 & 16.74 & 0.15 & 0.02 & 0.12 \\
\hline 148.27 & 107.97 & 20.031 & 46.95 & 0.54 & 0.25 & 0.28 \\
\hline 149.25 & 108.95 & 20.210 & 57.46 & 0.54 & 0.31 & 0.23 \\
\hline 153.97 & 111.67 & 20.706 & 71.63 & 0.59 & 0.42 & 0.17 \\
\hline 155.78 & 113.48 & 21.036 & 51.97 & 0.61 & 0.32 & 0.29 \\
\hline 156.62 & 114.32 & 21.190 & 43.52 & 0.58 & 0.25 & 0.33 \\
\hline 159.55 & 117.25 & 21.724 & 66.12 & 0.58 & 0.38 & 0.20 \\
\hline 160.07 & 117.77 & 21.819 & 41.12 & 0.58 & 0.24 & 0.34 \\
\hline 160.65 & 118.35 & 21.925 & 72.79 & 0.58 & 0.42 & 0.16 \\
\hline 161.05 & 118.75 & 21.998 & 76.75 & 0.58 & 0.44 & 0.13 \\
\hline 161.73 & 119.43 & 22.122 & 70.44 & 0.58 & 0.41 & 0.17 \\
\hline 162.55 & 120.25 & 22.272 & 65.05 & 0.58 & 0.38 & 0.20 \\
\hline 163.65 & 121.35 & 22.472 & 70.48 & 0.58 & 0.41 & 0.17 \\
\hline 168.76 & 126.46 & 23.405 & 75.40 & 0.58 & 0.44 & 0.14 \\
\hline 169.37 & 127.07 & 23.516 & 80.14 & 0.58 & 0.46 & 0.11 \\
\hline 169.88 & 127.58 & 23.609 & 88.46 & 0.58 & 0.51 & 0.07 \\
\hline 172.04 & 129.74 & 24.003 & 82.70 & 0.58 & 0.48 & 0.10 \\
\hline 172.38 & 130.08 & 24.065 & 86.99 & 0.58 & 0.50 & 0.08 \\
\hline 172.88 & 130.58 & 24.156 & 89.62 & 0.58 & 0.52 & 0.06 \\
\hline 173.34 & 131.04 & 24.240 & 88.05 & 0.55 & 0.48 & 0.07 \\
\hline 173.88 & 131.58 & 24.339 & 84.34 & 0.52 & 0.44 & 0.08 \\
\hline 178.58 & 136.28 & 25.196 & 88.84 & 0.52 & 0.47 & 0.06 \\
\hline 178.85 & 136.55 & 25.242 & 86.30 & 0.57 & 0.49 & 0.08 \\
\hline 179.14 & 136.84 & 25.291 & 82.79 & 0.54 & 0.45 & 0.09 \\
\hline 180.72 & 138.42 & 25.557 & 90.39 & 0.56 & 0.50 & 0.05 \\
\hline 180.96 & 138.66 & 25.597 & 91.46 & 0.58 & 0.53 & 0.05 \\
\hline 181.05 & 138.75 & 25.612 & 91.72 & 0.58 & 0.53 & 0.05 \\
\hline 181.58 & 138.28 & 25.533 & 93.24 & 0.58 & 0.54 & 0.04 \\
\hline 182.40 & 139.10 & 25.671 & 92.26 & 0.58 & 0.53 & 0.04 \\
\hline 183.08 & 139.78 & 25.786 & 93.20 & 0.58 & 0.54 & 0.04 \\
\hline 183.83 & 140.53 & 25.912 & 86.06 & 0.58 & 0.50 & 0.08 \\
\hline 184.04 & 140.74 & 25.947 & 92.26 & 0.58 & 0.53 & 0.04 \\
\hline 184.54 & 141.24 & 26.032 & 89.79 & 0.58 & 0.52 & 0.06 \\
\hline 184.65 & 141.35 & 26.050 & 84.91 & 0.58 & 0.49 & 0.09 \\
\hline 188.15 & 144.85 & 26.639 & 91.88 & 0.58 & 0.53 & 0.05 \\
\hline 188.67 & 145.37 & 26.727 & 88.88 & 0.58 & 0.51 & 0.06 \\
\hline 188.87 & 145.57 & 26.761 & 88.83 & 0.58 & 0.52 & 0.07 \\
\hline 189.25 & 145.95 & 26.825 & 92.56 & 0.60 & 0.56 & 0.04 \\
\hline 190.17 & 146.87 & 26.979 & 89.96 & 0.60 & 0.54 & 0.06 \\
\hline 190.27 & 146.97 & 26.996 & 92.26 & 0.62 & 0.57 & 0.05 \\
\hline 190.75 & 147.45 & 27.077 & 92.33 & 0.61 & 0.56 & 0.05 \\
\hline 191.15 & 147.85 & 27.144 & 86.26 & 0.61 & 0.53 & 0.08 \\
\hline 197.75 & 154.45 & 28.256 & 91.29 & 0.61 & 0.56 & 0.05 \\
\hline 198.27 & 154.97 & 28.343 & 83.62 & 0.61 & 0.51 & 0.10 \\
\hline 198.68 & 155.38 & 28.412 & 81.02 & 0.60 & 0.49 & 0.11 \\
\hline 198.85 & 155.55 & 28.441 & 87.93 & 0.60 & 0.53 & 0.07 \\
\hline 199.77 & 155.67 & 28.461 & 91.24 & 0.60 & 0.55 & 0.05 \\
\hline 200.35 & 156.25 & 28.559 & 90.77 & 0.60 & 0.55 & 0.06 \\
\hline 200.75 & 156.65 & 28.626 & 91.60 & 0.60 & 0.55 & 0.05 \\
\hline 200.93 & 156.83 & 28.656 & 88.93 & 0.61 & 0.54 & 0.07 \\
\hline 201.27 & 157.17 & 28.713 & 83.05 & 0.61 & 0.51 & 0.10 \\
\hline 201.85 & 157.75 & 28.811 & 91.60 & 0.61 & 0.56 & 0.05 \\
\hline 202.25 & 158.15 & 28.878 & 86.93 & 0.61 & 0.53 & 0.08 \\
\hline 202.77 & 158.67 & 28.966 & 85.60 & 0.61 & 0.52 & 0.09 \\
\hline 203.19 & 159.09 & 29.037 & 88.49 & 0.61 & 0.54 & 0.07 \\
\hline 205.55 & 159.75 & 29.148 & 90.23 & 0.61 & 0.55 & 0.06 \\
\hline 205.77 & 159.97 & 29.185 & 88.40 & 0.61 & 0.54 & 0.07 \\
\hline 206.35 & 160.55 & 29.282 & 90.28 & 0.61 & 0.55 & 0.06 \\
\hline 207.35 & 161.55 & 29.451 & 89.47 & 0.61 & 0.55 & 0.06 \\
\hline 207.87 & 162.07 & 29.538 & 93,45 & 0.61 & 0.57 & 0.04 \\
\hline 211.45 & 162.85 & 29.670 & 89.69 & 0.61 & 0.55 & 0.06 \\
\hline 211.85 & 163.25 & 29.737 & 85.48 & 0.61 & 0.52 & 0.09 \\
\hline 212.20 & 163.60 & 29.796 & 85.89 & 0.61 & 0.53 & 0.09 \\
\hline 212.37 & 163.77 & 29.825 & 80.90 & 0.59 & 0.47 & 0.11 \\
\hline
\end{tabular}


APPENDIX A (Continued)

\begin{tabular}{|c|c|c|c|c|c|c|}
\hline $\begin{array}{l}\text { Original } \\
\text { depth } \\
\text { (mbsf) }\end{array}$ & $\begin{array}{l}\text { Depth } \\
\text { used } \\
\text { (mbsf) }\end{array}$ & $\begin{array}{l}\text { Age } \\
(\mathrm{Ma})\end{array}$ & $\begin{array}{c}\mathrm{CaCO}_{3} \\
(\%)\end{array}$ & $\begin{array}{l}\text { Bulk } \\
\text { MAR }\end{array}$ & $\begin{array}{c}\mathrm{CaCO}_{3} \\
\mathrm{MAR}\end{array}$ & $\begin{array}{c}\text { Non- } \mathrm{CaCO}_{3} \\
\text { MAR }\end{array}$ \\
\hline \multicolumn{7}{|c|}{ Hole 708A (Cont.): } \\
\hline 212.95 & 164.35 & 29.922 & 87.49 & 0.59 & 0.51 & 0.07 \\
\hline 213.35 & 164.75 & 29.990 & 86.49 & 0.59 & 0.51 & 0.08 \\
\hline 213.87 & 165.27 & 30.077 & 85.12 & 0.59 & 0.50 & 0.09 \\
\hline 214.45 & 165.85 & 30.175 & 88.87 & 0.59 & 0.52 & 0.07 \\
\hline 218.15 & 166.85 & 30.343 & 85.84 & 0.56 & 0.48 & 0.08 \\
\hline 218.55 & 167.25 & 30.410 & 88.44 & 0.55 & 0.49 & 0.06 \\
\hline 219.07 & 167.77 & 30.498 & 81.88 & 0.55 & 0.45 & 0.10 \\
\hline 219.63 & 168.33 & 30.592 & 88.97 & 0.55 & 0.49 & 0.06 \\
\hline 220.05 & 168.75 & 30.663 & 88.13 & 0.55 & 0.49 & 0.07 \\
\hline 224.44 & 169.64 & 30.813 & 85.50 & 0.55 & 0.47 & 0.08 \\
\hline 226.75 & 171.95 & 31.202 & 86.00 & 0.55 & 0.48 & 0.08 \\
\hline 227.53 & 172.03 & 31.215 & 80.32 & 0.55 & 0.44 & 0.11 \\
\hline 227.85 & 172.35 & 31.269 & 93.78 & 0.55 & 0.52 & 0.03 \\
\hline 228.25 & 172.75 & 31.336 & 85.15 & 0.55 & 0.47 & 0.08 \\
\hline 229.22 & 173.22 & 31.415 & 86.63 & 0.55 & 0.48 & 0.07 \\
\hline 229.34 & 173.34 & 31.436 & 88.73 & 0.55 & 0.49 & 0.06 \\
\hline 229.75 & 173.75 & 31.505 & 85.33 & 0.55 & 0.47 & 0.08 \\
\hline 230.72 & 174.72 & 31.668 & 87.28 & 0.55 & 0.48 & 0.07 \\
\hline 230.84 & 174.84 & 31.688 & 89.37 & 0.55 & 0.49 & 0.06 \\
\hline 232.18 & 175.68 & 31.830 & 84.07 & 0.55 & 0.46 & 0.09 \\
\hline 232.80 & 175.80 & 31.850 & 86.80 & 0.55 & 0.47 & 0.07 \\
\hline 233.74 & 176.74 & 32.008 & 85.30 & 0.55 & 0.47 & 0.08 \\
\hline 233.84 & 176.84 & 32.025 & 89.65 & 0.55 & 0.49 & 0.06 \\
\hline 234.25 & 177.25 & 32.094 & 90.57 & 0.55 & 0.49 & 0.05 \\
\hline 234.38 & 177.38 & 32.116 & 80.71 & 0.55 & 0.44 & 0.11 \\
\hline 234.59 & 177.59 & 32.151 & 80.98 & 0.55 & 0.44 & 0.10 \\
\hline $\begin{array}{l}\text { Depth } \\
\text { (mbsf) }\end{array}$ & $\begin{array}{l}\text { Age } \\
(\mathrm{Ma})\end{array}$ & $\begin{array}{c}\mathrm{CaCO}_{3} \\
(\%)\end{array}$ & $\begin{array}{l}\text { Bulk } \\
\text { MAR }\end{array}$ & $\begin{array}{l}\mathrm{CaCO}_{3} \\
\mathrm{MAR}\end{array}$ & $\begin{array}{c}\text { Non- } \mathrm{CaCO}_{3} \\
\text { MAR }\end{array}$ & \\
\hline \multicolumn{7}{|l|}{ Hole 709A: } \\
\hline 0.25 & 0.02 & 85.46 & 1.05 & 0.90 & 0.15 & \\
\hline 0.77 & 0.06 & 87.69 & 1.05 & 0.92 & 0.13 & \\
\hline 1.35 & 0.11 & 86.16 & 1.05 & 0.90 & 0.15 & \\
\hline 1.75 & 0.14 & 88.06 & 1.05 & 0.92 & 0.13 & \\
\hline 2.07 & 0.17 & 91.05 & 1.05 & 0.95 & 0.09 & \\
\hline 2.27 & 0.18 & 88.67 & 1.03 & 0.91 & 0.12 & \\
\hline 2.85 & 0.23 & 89.32 & 1.03 & 0.92 & 0.11 & \\
\hline 3.25 & 0.26 & 91.02 & 1.03 & 0.94 & 0.09 & \\
\hline 3.77 & 0.31 & 88.22 & 1.03 & 0.91 & 0.12 & \\
\hline 4.35 & 0.35 & 91.40 & 1.03 & 0.94 & 0.09 & \\
\hline 4.75 & 0.39 & 88.23 & 1.03 & 0.91 & 0.12 & \\
\hline 5.07 & 0.41 & 89.72 & 1.01 & 0.91 & 0.10 & \\
\hline 5.27 & 0.43 & 88.91 & 1.02 & 0.91 & 0.11 & \\
\hline 5.85 & 0.47 & 88.24 & 1.02 & 0.90 & 0.12 & \\
\hline 6.25 & 0.51 & 90.56 & 1.02 & 0.93 & 0.10 & \\
\hline 6.77 & 0.55 & 87.08 & 1.02 & 0.89 & 0.13 & \\
\hline 7.35 & 0.60 & 88.57 & 1.02 & 0.91 & 0.12 & \\
\hline 7.75 & 0.63 & 87.67 & 1.02 & 0.90 & 0.13 & \\
\hline 8.07 & 0.65 & 90.72 & 1.04 & 0.94 & 0.10 & \\
\hline 8.27 & 0.67 & 84.35 & 1.05 & 0.88 & 0.16 & \\
\hline 8.85 & 0.72 & 88.35 & 1.05 & 0.93 & 0.12 & \\
\hline 9.25 & 0.75 & 89.65 & 0.91 & 0.82 & 0.09 & \\
\hline 9.77 & 0.80 & 82.78 & 0.91 & 0.76 & 0.16 & \\
\hline 9.90 & 0.81 & 86.92 & 0.91 & 0.79 & 0.12 & \\
\hline 10.35 & 0.86 & 88.21 & 0.91 & 0.81 & 0.11 & \\
\hline 10.87 & 0.90 & 87.63 & 0.91 & 0.80 & 0.11 & \\
\hline 11.45 & 0.96 & 88.20 & 0.91 & 0.81 & 0.11 & \\
\hline 11.85 & 1.00 & 88.50 & 0.91 & 0.81 & 0.10 & \\
\hline 12.16 & 1.02 & 90.41 & 0.92 & 0.83 & 0.09 & \\
\hline 12.37 & 1.04 & 86.83 & 0.91 & 0.79 & 0.12 & \\
\hline 12.95 & 1.10 & 88.74 & 0.91 & 0.81 & 0.10 & \\
\hline 13.35 & 1.14 & 86.29 & 0.91 & 0.78 & 0.12 & \\
\hline 13.87 & 1.18 & 88.61 & 0.91 & 0.80 & 0.10 & \\
\hline 14.45 & 1.24 & 88.19 & 0.91 & 0.80 & 0.11 & \\
\hline 14.85 & 1.27 & 90.00 & 0.91 & 0.82 & 0.09 & \\
\hline 15.16 & 1.30 & 88.60 & 0.89 & 0.79 & 0.10 & \\
\hline 15.37 & 1.32 & 87.85 & 0.96 & 0.84 & 0.12 & \\
\hline 15.95 & 1.38 & 90.80 & 0.96 & 0.87 & 0.09 & \\
\hline 16.35 & 1.41 & 88.53 & 0.96 & 0.85 & 0.11 & \\
\hline 16.87 & 1.46 & 87.84 & 0.96 & 0.84 & 0.12 & \\
\hline 17.45 & 1.52 & 89.67 & 0.96 & 0.86 & 0.10 & \\
\hline 17.85 & 1.55 & 90.77 & 0.96 & 0.87 & 0.09 & \\
\hline
\end{tabular}

APPENDIX A (Continued)

\begin{tabular}{|c|c|c|c|c|c|}
\hline $\begin{array}{l}\text { Depth } \\
\text { (mbsf) }\end{array}$ & $\begin{array}{l}\text { Age } \\
(\mathrm{Ma})\end{array}$ & $\begin{array}{c}\mathrm{CaCO}_{3} \\
(\%)\end{array}$ & $\begin{array}{l}\text { Bulk } \\
\text { MAR }\end{array}$ & $\begin{array}{l}\mathrm{CaCO}_{3} \\
\mathrm{MAR}\end{array}$ & $\begin{array}{c}\text { Non- } \mathrm{CaCO}_{3} \\
\text { MAR }\end{array}$ \\
\hline \multicolumn{6}{|c|}{ Hole 709A (Cont.): } \\
\hline 18.16 & 1.58 & 90.69 & 1.02 & 0.93 & 0.09 \\
\hline 18.37 & 1.60 & 87.47 & 1.02 & 0.89 & 0.13 \\
\hline 18.65 & 1.63 & 91.16 & 1.02 & 0.93 & 0.09 \\
\hline 19.95 & 1.75 & 88.23 & 1.02 & 0.90 & 0.12 \\
\hline 20.47 & 1.80 & 89.32 & 1.02 & 0.91 & 0.11 \\
\hline 21.05 & 1.85 & 91.01 & 1.02 & 0.93 & 0.09 \\
\hline 21.45 & 1.89 & 91.09 & 0.76 & 0.69 & 0.07 \\
\hline 21.66 & 1.92 & 92.29 & 0.75 & 0.69 & 0.06 \\
\hline 21.97 & 1.96 & 83.40 & 0.68 & 0.56 & 0.11 \\
\hline 22.55 & 2.03 & 91.07 & 0.68 & 0.62 & 0.06 \\
\hline 22.95 & 2.08 & 91.02 & 0.68 & 0.62 & 0.06 \\
\hline 23.47 & 2.15 & 89.47 & 0.68 & 0.61 & 0.07 \\
\hline 24.05 & 2.22 & 90.29 & 0.68 & 0.61 & 0.07 \\
\hline 24.45 & 2.27 & 91.26 & 0.68 & 0.62 & 0.06 \\
\hline 24.66 & 2.30 & 91.84 & 0.61 & 0.56 & 0.05 \\
\hline 24.97 & 2.33 & 89.30 & 0.67 & 0.60 & 0.07 \\
\hline 25.95 & 2.46 & 90.38 & 0.67 & 0.60 & 0.06 \\
\hline 26.47 & 2.52 & 87.89 & 0.65 & 0.57 & 0.08 \\
\hline 27.05 & 2.60 & 91.15 & 0.65 & 0.59 & 0.06 \\
\hline 27.45 & 2.65 & 89.95 & 0.65 & 0.58 & 0.07 \\
\hline 27.66 & 2.68 & 92.12 & 0.71 & 0.66 & 0.06 \\
\hline 27.97 & 2.72 & 88.25 & 0.71 & 0.63 & 0.08 \\
\hline 28.55 & 2.79 & 89.69 & 0.71 & 0.64 & 0.07 \\
\hline 28.95 & 2.84 & 89.87 & 0.71 & 0.64 & 0.07 \\
\hline 29.65 & 2.94 & 87.21 & 0.71 & 0.62 & 0.09 \\
\hline 30.17 & 3.00 & 85.35 & 0.71 & 0.60 & 0.10 \\
\hline 30.75 & 3.08 & 89.73 & 0.71 & 0.64 & 0.07 \\
\hline 31.15 & 3.13 & 91.90 & 0.71 & 0.65 & 0.06 \\
\hline 31.37 & 3.16 & 89.77 & 0.70 & 0.63 & 0.07 \\
\hline 31.67 & 3.20 & 86.79 & 0.71 & 0.61 & 0.09 \\
\hline 32.25 & 3.27 & 89.08 & 0.71 & 0.63 & 0.08 \\
\hline 32.65 & 3.32 & 97.65 & 0.71 & 0.69 & 0.02 \\
\hline 33.17 & 3.39 & 88.39 & 0.71 & 0.63 & 0.08 \\
\hline 33.75 & 3.43 & 89.33 & 1.50 & 1.34 & 0.16 \\
\hline 34.15 & 3.45 & 88.77 & 1.50 & 1.33 & 0.17 \\
\hline 34.37 & 3.47 & 90.77 & 1.51 & 1.37 & 0.14 \\
\hline 34.67 & 3.49 & 86.15 & 1.55 & 1.33 & 0.21 \\
\hline 35.25 & 3.52 & 90.59 & 1.55 & 1.40 & 0.15 \\
\hline 35.65 & 3.55 & 88.99 & 1.55 & 1.38 & 0.17 \\
\hline 35.89 & 3.56 & 86.78 & 1.55 & 1.34 & 0.20 \\
\hline 49.47 & 4.39 & 88.86 & 1.55 & 1.38 & 0.17 \\
\hline 50.05 & 4.43 & 92.78 & 1.55 & 1.44 & 0.11 \\
\hline 50.45 & 4.45 & 91.17 & 1.59 & 1.45 & 0.14 \\
\hline 50.97 & 4.48 & 85.28 & 1.57 & 1.34 & 0.23 \\
\hline 50.99 & 4.48 & 91.72 & 1.57 & 1.44 & 0.13 \\
\hline 51.55 & 4.52 & 91.02 & 1.57 & 1.43 & 0.14 \\
\hline 51.95 & 4.54 & 90.34 & 1.57 & 1.42 & 0.15 \\
\hline 52.47 & 4.57 & 87.19 & 1.57 & 1.37 & 0.20 \\
\hline 53.05 & 4.61 & 93.80 & 1.57 & 1.47 & 0.10 \\
\hline 53.45 & 4.63 & 89.36 & 1.56 & 1.39 & 0.17 \\
\hline 53.97 & 4.67 & 87.68 & 1.52 & 1.34 & 0.19 \\
\hline 53.99 & 4.67 & 92.55 & 1.52 & 1.41 & 0.11 \\
\hline 54.55 & 4.70 & 93.80 & 1.52 & 1.43 & 0.09 \\
\hline 54.95 & 4.72 & 92.47 & 1.52 & 1.41 & 0.11 \\
\hline 55.47 & 4.76 & 88.46 & 1.52 & 1.35 & 0.18 \\
\hline 56.05 & 4.79 & 91.06 & 1.52 & 1.39 & 0.14 \\
\hline 56.45 & 4.82 & 90.05 & 1.49 & 1.34 & 0.15 \\
\hline 56.97 & 4.85 & 85.63 & 1.47 & 1.26 & 0.21 \\
\hline 56.99 & 4.85 & 89.88 & 1.47 & 1.32 & 0.15 \\
\hline 57.55 & 4.88 & 91.13 & 1.47 & 1.34 & 0.13 \\
\hline 57.95 & 4.91 & 90.13 & 1.47 & 1.33 & 0.15 \\
\hline 58.55 & 4.94 & 88.09 & 1.47 & 1.30 & 0.18 \\
\hline 59.07 & 4.98 & 87.70 & 1.47 & 1.29 & 0.18 \\
\hline 59.65 & 5.01 & 89.45 & 1.47 & 1.32 & 0.16 \\
\hline 60.05 & 5.04 & 89.38 & 1.47 & 1.32 & 0.16 \\
\hline 60.36 & 5.06 & 88.14 & 1.46 & 1.28 & 0.17 \\
\hline 60.57 & 5.07 & 87.59 & 1.50 & 1.31 & 0.19 \\
\hline 61.15 & 5.10 & 90.53 & 1.50 & 1.36 & 0.14 \\
\hline 61.65 & 5.13 & 89.32 & 1.50 & 1.34 & 0.16 \\
\hline 62.07 & 5.16 & 84.95 & 1.50 & 1.27 & 0.23 \\
\hline 62.65 & 5.20 & 92.73 & 1.50 & 1.39 & 0.11 \\
\hline 63.05 & 5.22 & 91.47 & 1.50 & 1.37 & 0.13 \\
\hline 63.36 & 5.24 & 90.55 & 1.54 & 1.39 & 0.15 \\
\hline 63.57 & 5.25 & 87.04 & 1.56 & 1.35 & 0.20 \\
\hline 64.15 & 5.29 & 91.21 & 1.56 & 1.42 & 0.14 \\
\hline
\end{tabular}


APPENDIX A (Continued)

\begin{tabular}{|c|c|c|c|c|c|}
\hline $\begin{array}{l}\text { Depth } \\
\text { (mbsf) }\end{array}$ & $\begin{array}{l}\text { Age } \\
\text { (Ma) }\end{array}$ & $\begin{array}{c}\mathrm{CaCO}_{3} \\
(\%)\end{array}$ & $\begin{array}{l}\text { Bulk } \\
\text { MAR }\end{array}$ & $\begin{array}{c}\mathrm{CaCO}_{3} \\
\text { MAR }\end{array}$ & $\begin{array}{c}\text { Non-CaCO } \\
\text { MAR }\end{array}$ \\
\hline \multicolumn{6}{|c|}{ Hole 709A (Cont.): } \\
\hline 64.55 & 5.31 & 91.92 & 1.56 & 1.43 & 0.13 \\
\hline 65.07 & 5.34 & 86.14 & 1.56 & 1.34 & 0.22 \\
\hline 66.05 & 5.40 & 89.22 & 1.56 & 1.39 & 0.17 \\
\hline 66.36 & 5.42 & 85.65 & 1.57 & 1.35 & 0.23 \\
\hline 66.57 & 5.43 & 89.00 & 1.60 & 1.42 & 0.18 \\
\hline 67.15 & 5.47 & 88.95 & 1.60 & 1.42 & 0.18 \\
\hline 68.25 & 5.54 & 89.71 & 1.60 & 1.43 & 0.16 \\
\hline 68.77 & 5.57 & 92.48 & 1.60 & 1.48 & 0.12 \\
\hline 69.35 & 5.60 & 92.22 & 1.60 & 1.47 & 0.12 \\
\hline 69.75 & 5.63 & 92.72 & 1.60 & 1.48 & 0.12 \\
\hline 70.07 & 5.65 & 91.85 & 1.62 & 1.49 & 0.13 \\
\hline 70.27 & 5.66 & 86.95 & 1.65 & 1.43 & 0.21 \\
\hline 70.85 & 5.70 & 92.39 & 1.65 & 1.52 & 0.13 \\
\hline 71.25 & 5.72 & 90.57 & 1.65 & 1.49 & 0.16 \\
\hline 71.77 & 5.75 & 87.98 & 1.65 & 1.45 & 0.20 \\
\hline 72.35 & 5.79 & 91.80 & 1.65 & 1.51 & 0.13 \\
\hline 72.75 & 5.81 & 91.18 & 1.65 & 1.50 & 0.15 \\
\hline 73.07 & 5.83 & 93.67 & 1.67 & 1.56 & 0.11 \\
\hline 73.27 & 5.84 & 87.98 & 1.62 & 1.43 & 0.19 \\
\hline 73.85 & 5.88 & 92.30 & 1.62 & 1.50 & 0.12 \\
\hline 74.25 & 5.90 & 92.09 & 1.62 & 1.49 & 0.13 \\
\hline 74.77 & 5.93 & 84.87 & 1.62 & 1.38 & 0.25 \\
\hline 75.35 & 5.97 & 89.73 & 1.62 & 1.45 & 0.17 \\
\hline 75.75 & 5.99 & 93.27 & 1.62 & 1.51 & 0.11 \\
\hline 76.07 & 6.01 & 89.33 & 1.57 & 1.40 & 0.17 \\
\hline 76.27 & 6.03 & 87.52 & 1.61 & 1.40 & 0.20 \\
\hline 76.85 & 6.06 & 87.21 & 1.61 & 1.40 & 0.21 \\
\hline 77.85 & 6.12 & 90.00 & 1.61 & 1.44 & 0.16 \\
\hline 78.37 & 6.15 & 88.09 & 1.61 & 1.41 & 0.19 \\
\hline 78.95 & 6.19 & 93.14 & 1.61 & 1.50 & 0.11 \\
\hline 79.35 & 6.21 & 92.94 & 1.61 & 1.49 & 0.11 \\
\hline 79.67 & 6.23 & 88.88 & 1.64 & 1.46 & 0.18 \\
\hline 79.87 & 6.25 & 87.25 & 1.66 & 1.45 & 0.21 \\
\hline 80.45 & 6.28 & 91.85 & 1.66 & 1.53 & 0.14 \\
\hline 80.85 & 6.31 & 92.94 & 1.66 & 1.55 & 0.12 \\
\hline 81.37 & 6.34 & 88.36 & 1.66 & 1.47 & 0.19 \\
\hline 81.95 & 6.37 & 92.91 & 1.66 & 1.54 & 0.12 \\
\hline 82.35 & 6.40 & 91.79 & 1.66 & 1.53 & 0.14 \\
\hline 82.80 & 6.43 & 91.56 & 1.65 & 1.51 & 0.14 \\
\hline 82.87 & 6.43 & 86.21 & 1.69 & 1.45 & 0.23 \\
\hline 83.45 & 6.46 & 89.68 & 1.69 & 1.51 & 0.17 \\
\hline 83.85 & 6.49 & 90.42 & 1.69 & 1.53 & 0.16 \\
\hline 84.37 & 6.52 & 86.07 & 1.69 & 1.45 & 0.24 \\
\hline 84.95 & 6.56 & 98.51 & 1.69 & 1.66 & 0.03 \\
\hline 85.35 & 6.58 & 93.92 & 1.69 & 1.58 & 0.10 \\
\hline 85.67 & 6.60 & 92.76 & 1.72 & 1.60 & 0.12 \\
\hline 85.87 & 6.61 & 87.90 & 1.70 & 1.49 & 0.21 \\
\hline 86.45 & 6.65 & 89.97 & 1.70 & 1.53 & 0.17 \\
\hline 87.50 & 6.72 & 92.90 & 1.18 & 1.10 & 0.08 \\
\hline 88.07 & 6.77 & 86.69 & 1.18 & 1.02 & 0.16 \\
\hline 88.70 & 6.82 & 91.85 & 1.18 & 1.08 & 0.10 \\
\hline 89.00 & 6.85 & 90.27 & 1.18 & 1.07 & 0.11 \\
\hline 89.57 & 6.90 & 87.71 & 1.18 & 1.03 & 0.15 \\
\hline 90.20 & 6.95 & 91.47 & 1.18 & 1.08 & 0.10 \\
\hline 90.50 & 6.98 & 89.69 & 1.18 & 1.06 & 0.12 \\
\hline 90.98 & 7.02 & 90.39 & 1.16 & 1.05 & 0.11 \\
\hline 91.07 & 7.03 & 85.04 & 1.16 & 0.98 & 0.17 \\
\hline 91.70 & 7.09 & 89.88 & 1.16 & 1.04 & 0.12 \\
\hline 92.00 & 7.11 & 90.17 & 1.16 & 1.04 & 0.11 \\
\hline 92.57 & 7.16 & 88.56 & 1.16 & 1.02 & 0.13 \\
\hline 93.20 & 7.22 & 88.50 & 1.16 & 1.02 & 0.13 \\
\hline 93.50 & 7.24 & 92.05 & 1.16 & 1.07 & 0.09 \\
\hline 94.07 & 7.29 & 85.73 & 1.16 & 0.99 & 0.17 \\
\hline 94.10 & 7.30 & 91.07 & 1.16 & 1.05 & 0.10 \\
\hline 95.00 & 7.38 & 90.41 & 1.16 & 1.05 & 0.11 \\
\hline 95.32 & 7.40 & 92.58 & 1.15 & 1.07 & 0.09 \\
\hline 95.57 & 7.43 & 87.99 & 1.05 & 0.93 & 0.13 \\
\hline 96.20 & 7.48 & 93.20 & 1.05 & 0.98 & 0.07 \\
\hline 96.42 & 7.50 & 92.94 & 1.05 & 0.98 & 0.07 \\
\hline 96.80 & 7.53 & 88.42 & 1.05 & 0.93 & 0.12 \\
\hline 97.10 & 7.56 & 91.64 & 1.05 & 0.97 & 0.09 \\
\hline 97.15 & 7.56 & 92.51 & 1.05 & 0.98 & 0.08 \\
\hline 97.67 & 7.61 & 85.83 & 1.05 & 0.91 & 0.15 \\
\hline 98.25 & 7.66 & 92.42 & 1.05 & 0.97 & 0.08 \\
\hline 98.65 & 7.70 & 92.13 & 1.05 & 0.97 & 0.08 \\
\hline
\end{tabular}

APPENDIX A (Continued)

\begin{tabular}{|c|c|c|c|c|c|}
\hline $\begin{array}{l}\text { Depth } \\
\text { (mbsf) }\end{array}$ & $\begin{array}{l}\text { Age } \\
\text { (Ma) }\end{array}$ & $\begin{array}{c}\mathrm{CaCO}_{3} \\
(\%)\end{array}$ & $\begin{array}{l}\text { Bulk } \\
\text { MAR }\end{array}$ & $\begin{array}{c}\mathrm{CaCO}_{3} \\
\mathrm{MAR}\end{array}$ & $\begin{array}{c}\text { Non- } \mathrm{CaCO}_{3} \\
\text { MAR }\end{array}$ \\
\hline \multicolumn{6}{|c|}{ Hole 709A (Cont.): } \\
\hline 99.17 & 7.74 & 86.98 & 1.05 & 0.92 & 0.14 \\
\hline 99.26 & 7.75 & 92.24 & 0.96 & 0.88 & 0.07 \\
\hline 99.75 & 7.79 & 90.82 & 1.11 & 1.01 & 0.10 \\
\hline 100.15 & 7.83 & 91.59 & 1.11 & 1.02 & 0.09 \\
\hline 100.67 & 7.87 & 86.45 & 1.11 & 0.96 & 0.15 \\
\hline 101.25 & 7.92 & 91.83 & 1.11 & 1.02 & 0.09 \\
\hline 103.15 & 8.09 & 91.64 & 1.21 & 1.11 & 0.10 \\
\hline 103.67 & 8.14 & 87.08 & 1.21 & 1.05 & 0.16 \\
\hline 104.25 & 8.19 & 93.33 & 1.21 & 1.13 & 0.08 \\
\hline 104.65 & 8.22 & 92.50 & 1.21 & 1.12 & 0.09 \\
\hline 105.17 & 8.27 & 88.00 & 1.21 & 1.06 & 0.15 \\
\hline 106.01 & 8.34 & 86.69 & 1.27 & 1.10 & 0.17 \\
\hline 106.15 & 8.35 & 93.62 & 1.24 & 1.16 & 0.08 \\
\hline 106.85 & 8.41 & 85.04 & 1.24 & 1.05 & 0.19 \\
\hline 107.37 & 8.46 & 76.32 & 1.24 & 0.94 & 0.29 \\
\hline 107.95 & 8.51 & 80.20 & 1.24 & 0.99 & 0.24 \\
\hline 108.35 & 8.55 & 90.56 & 1.24 & 1.12 & 0.12 \\
\hline 108.87 & 8.59 & 88.11 & 1.24 & 1.09 & 0.15 \\
\hline 109.45 & 8.64 & 91.25 & 1.24 & 1.13 & 0.11 \\
\hline 109.85 & 8.68 & 87.96 & 1.24 & 1.09 & 0.15 \\
\hline 110.37 & 8.81 & 85.52 & 0.27 & 0.23 & 0.04 \\
\hline 110.95 & 9.04 & 88.09 & 0.27 & 0.24 & 0.03 \\
\hline 111.35 & 9.20 & 77.30 & 0.27 & 0.21 & 0.06 \\
\hline 111.87 & 9.41 & 85.16 & 0.27 & 0.23 & 0.04 \\
\hline 112.45 & 9.64 & 88.40 & 0.27 & 0.24 & 0.03 \\
\hline 112.85 & 9.80 & 83.66 & 0.27 & 0.23 & 0.04 \\
\hline 113.37 & 10.00 & 82.88 & 0.27 & 0.23 & 0.05 \\
\hline 113.95 & 10.23 & 83.65 & 0.27 & 0.23 & 0.04 \\
\hline 114.35 & 10.39 & 80.42 & 0.27 & 0.22 & 0.05 \\
\hline 114.87 & 10.60 & 80.15 & 0.27 & 0.22 & 0.05 \\
\hline 116.97 & 11.44 & 80.83 & 0.27 & 0.22 & 0.05 \\
\hline 117.90 & 11.81 & 88.65 & 0.27 & 0.24 & 0.03 \\
\hline 119.97 & 12.63 & 84.49 & 0.26 & 0.22 & 0.04 \\
\hline 120.83 & 12.97 & 89.30 & 0.25 & 0.23 & 0.03 \\
\hline 121.47 & 13.23 & 79.25 & 0.26 & 0.21 & 0.05 \\
\hline 122.97 & 13.83 & 83.18 & 0.26 & 0.22 & 0.04 \\
\hline 174.75 & 21.66 & 89.12 & 0.67 & 0.59 & 0.07 \\
\hline 175.07 & 21.72 & 85.60 & 0.67 & 0.57 & 0.10 \\
\hline 175.85 & 21.85 & 85.60 & 0.67 & 0.57 & 0.10 \\
\hline 176.25 & 21.92 & 89.97 & 0.67 & 0.60 & 0.07 \\
\hline 176.57 & 21.97 & 84.60 & 0.67 & 0.56 & 0.10 \\
\hline 177.11 & 22.06 & 90.84 & 0.67 & 0.61 & 0.06 \\
\hline 177.75 & 22.17 & 91.25 & 0.67 & 0.61 & 0.06 \\
\hline 178.00 & 22.22 & 90.82 & 0.68 & 0.62 & 0.06 \\
\hline 178.85 & 22.36 & 92.28 & 0.65 & 0.60 & 0.05 \\
\hline 179.25 & 22.43 & 92.13 & 0.65 & 0.60 & 0.05 \\
\hline 179.57 & 22.49 & 85.25 & 0.65 & 0.55 & 0.10 \\
\hline 179.85 & 22.53 & 92.13 & 0.65 & 0.60 & 0.05 \\
\hline 184.85 & 23.39 & 91.73 & 0.65 & 0.59 & 0.05 \\
\hline 185.25 & 23.46 & 91.72 & 0.65 & 0.59 & 0.05 \\
\hline 185.65 & 23.52 & 92.41 & 0.65 & 0.60 & 0.05 \\
\hline 185.97 & 23.58 & 91.17 & 0.61 & 0.56 & 0.05 \\
\hline 186.17 & 23.61 & 88.73 & 0.60 & 0.53 & 0.07 \\
\hline 186.75 & 23.71 & 80.92 & 0.60 & 0.48 & 0.11 \\
\hline 187.15 & 23.78 & 91.88 & 0.60 & 0.55 & 0.05 \\
\hline 187.70 & 23.88 & 87.13 & 0.60 & 0.52 & 0.08 \\
\hline 188.25 & 23.97 & 90.60 & 0.60 & 0.54 & 0.06 \\
\hline 188.65 & 24.04 & 91.54 & 0.60 & 0.55 & 0.05 \\
\hline 189.17 & 24.13 & 90.07 & 0.60 & 0.54 & 0.06 \\
\hline 189.75 & 24.23 & 93.47 & 0.60 & 0.56 & 0.04 \\
\hline 190.15 & 24.29 & 91.32 & 0.60 & 0.54 & 0.05 \\
\hline 190.50 & 24.35 & 92.51 & 0.58 & 0.54 & 0.04 \\
\hline 190.67 & 24.38 & 88.10 & 0.60 & 0.53 & 0.07 \\
\hline 191.25 & 24.48 & 89.37 & 0.60 & 0.53 & 0.06 \\
\hline 191.65 & 24.55 & 91.12 & 0.60 & 0.54 & 0.05 \\
\hline 192.17 & 24.64 & 87.91 & 0.60 & 0.52 & 0.07 \\
\hline 193.75 & 24.91 & 92.87 & 0.60 & 0.55 & 0.04 \\
\hline 194.27 & 25.00 & 88.95 & 0.60 & 0.53 & 0.07 \\
\hline 194.85 & 25.10 & 90.50 & 0.60 & 0.54 & 0.06 \\
\hline 195.25 & 25.17 & 89.01 & 0.60 & 0.53 & 0.07 \\
\hline 195.77 & 25.26 & 89.24 & 0.60 & 0.53 & 0.06 \\
\hline 196.35 & 25.35 & 92.13 & 0.60 & 0.55 & 0.05 \\
\hline 196.75 & 25.42 & 92.68 & 0.60 & 0.55 & 0.04 \\
\hline 197.07 & 25.48 & 93.09 & 0.61 & 0.57 & 0.04 \\
\hline
\end{tabular}


APPENDIX A (Continued)

\begin{tabular}{|c|c|c|c|c|c|}
\hline $\begin{array}{l}\text { Depth } \\
\text { (mbsf) }\end{array}$ & $\begin{array}{l}\text { Age } \\
(\mathrm{Ma})\end{array}$ & $\begin{array}{c}\mathrm{CaCO}_{3} \\
(\%)\end{array}$ & $\begin{array}{l}\text { Bulk } \\
\text { MAR }\end{array}$ & $\begin{array}{c}\mathrm{CaCO}_{3} \\
\mathrm{MAR}\end{array}$ & $\begin{array}{c}\text { Non- } \mathrm{CaCO}_{3} \\
\text { MAR }\end{array}$ \\
\hline \multicolumn{6}{|l|}{ Hole $709 \mathrm{C}$ : } \\
\hline 200.07 & 25.21 & 92.10 & 0.72 & 0.67 & 0.06 \\
\hline 200.47 & 25.27 & 87.11 & 0.72 & 0.63 & 0.09 \\
\hline 200.85 & 25.32 & 93.07 & 0.72 & 0.67 & 0.05 \\
\hline 200.97 & 25.33 & 89.66 & 0.72 & 0.65 & 0.07 \\
\hline 201.25 & 25.37 & 93.80 & 0.72 & 0.68 & 0.04 \\
\hline 201.57 & 25.42 & 94.18 & 0.72 & 0.68 & 0.04 \\
\hline 201.97 & 25.47 & 94.66 & 0.72 & 0.69 & 0.04 \\
\hline 203.07 & 25.63 & 94.09 & 0.72 & 0.68 & 0.04 \\
\hline 203.47 & 25.68 & 93.55 & 0.72 & 0.68 & 0.05 \\
\hline 204.57 & 25.83 & 90.07 & 0.72 & 0.65 & 0.07 \\
\hline 204.97 & 25.89 & 93.07 & 0.72 & 0.67 & 0.05 \\
\hline 206.07 & 26.04 & 87.76 & 0.72 & 0.64 & 0.09 \\
\hline 206.10 & 26.05 & 93.06 & 0.75 & 0.70 & 0.05 \\
\hline 206.15 & 26.05 & 93.43 & 0.75 & 0.70 & 0.05 \\
\hline 208.65 & 26.40 & 92.05 & 0.76 & 0.70 & 0.06 \\
\hline 209.75 & 26.55 & 93.57 & 0.76 & 0.71 & 0.05 \\
\hline 210.15 & 26.61 & 91.88 & 0.76 & 0.70 & 0.06 \\
\hline 211.25 & 26.76 & 88.19 & 0.76 & 0.67 & 0.09 \\
\hline 211.65 & 26.82 & 93.12 & 0.76 & 0.71 & 0.05 \\
\hline 212.75 & 26.97 & 93.98 & 0.76 & 0.72 & 0.05 \\
\hline 213.15 & 27.02 & 94.09 & 0.76 & 0.72 & 0.04 \\
\hline 214.25 & 27.18 & 94.15 & 0.76 & 0.72 & 0.04 \\
\hline 214.65 & 27.23 & 92.27 & 0.76 & 0.70 & 0.06 \\
\hline 215.75 & 27.38 & 91.66 & 0.77 & 0.71 & 0.06 \\
\hline 218.25 & 27.73 & 92.90 & 0.75 & 0.70 & 0.05 \\
\hline 219.35 & 27.88 & 94.40 & 0.75 & 0.71 & 0.04 \\
\hline 219.75 & 27.94 & 92.95 & 0.75 & 0.70 & 0.05 \\
\hline 220.85 & 28.09 & 93.20 & 0.75 & 0.70 & 0.05 \\
\hline 221.25 & 28.15 & 91.24 & 0.75 & 0.68 & 0.07 \\
\hline 222.35 & 28.30 & 89.58 & 0.75 & 0.67 & 0.08 \\
\hline 222.75 & 28.35 & 91.38 & 0.75 & 0.69 & 0.06 \\
\hline 223.85 & 28.51 & 92.22 & 0.75 & 0.69 & 0.06 \\
\hline 224.25 & 28.56 & 91.06 & 0.75 & 0.68 & 0.07 \\
\hline 225.35 & 28.72 & 82.51 & 0.75 & 0.62 & 0.13 \\
\hline 225.39 & 28.72 & 91.18 & 0.73 & 0.66 & 0.06 \\
\hline 225.44 & 28.73 & 90.77 & 0.74 & 0.67 & 0.07 \\
\hline 225.75 & 28.77 & 92.68 & 0.73 & 0.68 & 0.05 \\
\hline 227.95 & 29.08 & 90.67 & 0.73 & 0.66 & 0.07 \\
\hline 229.05 & 29.23 & 92.12 & 0.73 & 0.67 & 0.06 \\
\hline 229.45 & 29.28 & 92.52 & 0.73 & 0.67 & 0.05 \\
\hline 230.55 & 29.44 & 91.18 & 0.73 & 0.66 & 0.06 \\
\hline 230.95 & 29.49 & 86.91 & 0.73 & 0.63 & 0.10 \\
\hline 232.05 & 29.64 & 90.16 & 0.73 & 0.66 & 0.07 \\
\hline 232.45 & 29.70 & 80.73 & 0.73 & 0.59 & 0.14 \\
\hline 233.55 & 29.85 & 91.90 & 0.73 & 0.67 & 0.06 \\
\hline 233.95 & 29.91 & 86.13 & 0.73 & 0.63 & 0.10 \\
\hline 235.03 & 30.06 & 84.59 & 0.72 & 0.61 & 0.11 \\
\hline 235.05 & 30.06 & 72.66 & 0.71 & 0.52 & 0.20 \\
\hline 235.10 & 30.07 & 83.15 & 0.71 & 0.59 & 0.12 \\
\hline 237.65 & 30.42 & 81.38 & 0.72 & 0.59 & 0.13 \\
\hline 238.75 & 30.57 & 93.59 & 0.72 & 0.67 & 0.05 \\
\hline 239.15 & 30.63 & 86.85 & 0.72 & 0.63 & 0.09 \\
\hline 240.25 & 30.78 & 93.86 & 0.72 & 0.68 & 0.04 \\
\hline 240.65 & 30.84 & 82.01 & 0.72 & 0.59 & 0.13 \\
\hline 241.20 & 30.91 & 88.52 & 0.72 & 0.64 & 0.08 \\
\hline 241.26 & 30.92 & 92.11 & 0.72 & 0.66 & 0.06 \\
\hline 241.75 & 30.99 & 93.60 & 0.72 & 0.68 & 0.05 \\
\hline 242.15 & 31.04 & 91.61 & 0.72 & 0.66 & 0.06 \\
\hline 242.70 & 31.12 & 89.34 & 0.72 & 0.64 & 0.08 \\
\hline 243.25 & 31.20 & 94.33 & 0.72 & 0.68 & 0.04 \\
\hline 243.65 & 31.25 & 94.94 & 0.72 & 0.68 & 0.04 \\
\hline 244.75 & 31.41 & 94.64 & 0.72 & 0.68 & 0.04 \\
\hline 244.78 & 31.41 & 95.94 & 0.74 & 0.71 & 0.03 \\
\hline 245.15 & 31.46 & 95.94 & 0.76 & 0.73 & 0.03 \\
\hline 246.25 & 31.61 & 95.25 & 0.76 & 0.72 & 0.04 \\
\hline 247.25 & 31.75 & 93.75 & 0.76 & 0.71 & 0.05 \\
\hline 247.80 & 31.83 & 88.98 & 0.76 & 0.67 & 0.08 \\
\hline 248.35 & 31.90 & 93.82 & 0.76 & 0.71 & 0.05 \\
\hline 248.75 & 31.96 & 93.18 & 0.76 & 0.71 & 0.05 \\
\hline 249.30 & 32.04 & 89.02 & 0.76 & 0.67 & 0.08 \\
\hline 249.85 & 32.11 & 89.97 & 0.76 & 0.68 & 0.08 \\
\hline 250.25 & 32.17 & 91.84 & 0.76 & 0.70 & 0.06 \\
\hline 250.60 & 32.22 & 91.89 & 0.78 & 0.72 & 0.06 \\
\hline 250.80 & 32.24 & 72.90 & 0.72 & 0.53 & 0.20 \\
\hline 251.35 & 32.32 & 90.45 & 0.72 & 0.66 & 0.07 \\
\hline
\end{tabular}

APPENDIX A (Continued)

\begin{tabular}{|c|c|c|c|c|c|}
\hline $\begin{array}{l}\text { Depth } \\
\text { (mbsf) }\end{array}$ & $\begin{array}{l}\text { Age } \\
(\mathrm{Ma})\end{array}$ & $\begin{array}{c}\mathrm{CaCO}_{3} \\
(\%)\end{array}$ & $\begin{array}{l}\text { Bulk } \\
\text { MAR }\end{array}$ & $\begin{array}{c}\mathrm{CaCO}_{3} \\
\mathrm{MAR}^{2}\end{array}$ & $\begin{array}{c}\text { Non- } \mathrm{CaCO}_{3} \\
\text { MAR }\end{array}$ \\
\hline \multicolumn{6}{|c|}{ Hole $709 \mathrm{C}$ (Cont.): } \\
\hline 251.75 & 32.38 & 92.42 & 0.72 & 0.67 & 0.05 \\
\hline 252.30 & 32.45 & 88.28 & 0.72 & 0.64 & 0.08 \\
\hline 252.85 & 32.53 & 91.21 & 0.72 & 0.66 & 0.06 \\
\hline 256.95 & 33.10 & 91.05 & 0.72 & 0.66 & 0.06 \\
\hline 257.50 & 33.17 & 88.66 & 0.72 & 0.64 & 0.08 \\
\hline 258.05 & 33.25 & 92.62 & 0.72 & 0.67 & 0.05 \\
\hline 258.45 & 33.30 & 92.15 & 0.72 & 0.67 & 0.06 \\
\hline 259.00 & 33.38 & 87.08 & 0.72 & 0.63 & 0.09 \\
\hline 259.30 & 33.42 & 90.91 & 0.72 & 0.66 & 0.07 \\
\hline 259.95 & 33.51 & 92.82 & 0.72 & 0.67 & 0.05 \\
\hline 260.50 & 33.59 & 90.03 & 0.72 & 0.65 & 0.07 \\
\hline 261.12 & 33.67 & 91.80 & 0.67 & 0.62 & 0.05 \\
\hline 261.15 & 33.68 & 92.02 & 0.69 & 0.63 & 0.05 \\
\hline 265.00 & 34.21 & 91.91 & 0.69 & 0.63 & 0.06 \\
\hline 266.65 & 34.44 & 87.77 & 0.69 & 0.60 & 0.08 \\
\hline 267.20 & 34.52 & 84.59 & 0.69 & 0.58 & 0.11 \\
\hline 267.75 & 34.59 & 93.07 & 0.69 & 0.64 & 0.05 \\
\hline 268.15 & 34.65 & 91.30 & 0.69 & 0.63 & 0.06 \\
\hline 268.70 & 34.73 & 90.22 & 0.69 & 0.62 & 0.07 \\
\hline 269.25 & 34.80 & 92.59 & 0.69 & 0.64 & 0.05 \\
\hline 269.65 & 34.86 & 92.88 & 0.69 & 0.64 & 0.05 \\
\hline 270.05 & 34.91 & 94.59 & 0.71 & 0.67 & 0.04 \\
\hline 270.75 & 35.01 & 93.44 & 0.74 & 0.69 & 0.05 \\
\hline 271.15 & 35.07 & 92.21 & 0.74 & 0.68 & 0.06 \\
\hline 271.70 & 35.14 & 90.18 & 0.74 & 0.67 & 0.07 \\
\hline 272.25 & 35.22 & 92.07 & 0.74 & 0.68 & 0.06 \\
\hline 272.65 & 35.27 & 92.19 & 0.74 & 0.68 & 0.06 \\
\hline 273.75 & 35.43 & 92.38 & 0.74 & 0.68 & 0.06 \\
\hline 274.15 & 35.48 & 91.28 & 0.74 & 0.67 & 0.06 \\
\hline 274.37 & 35.51 & 93.69 & 0.77 & 0.72 & 0.05 \\
\hline 274.70 & 35.56 & 91.97 & 0.79 & 0.72 & 0.06 \\
\hline 275.25 & 35.63 & 92.36 & 0.79 & 0.73 & 0.06 \\
\hline 275.65 & 35.69 & 91.78 & 0.79 & 0.72 & 0.06 \\
\hline 276.35 & 35.79 & 92.77 & 0.79 & 0.73 & 0.06 \\
\hline 276.90 & 35.86 & 91.18 & 0.79 & 0.72 & 0.07 \\
\hline 277.45 & 35.94 & 90.15 & 0.79 & 0.71 & 0.08 \\
\hline 278.95 & 36.15 & 91.69 & 0.79 & 0.72 & 0.07 \\
\hline 279.35 & 36.20 & 89.70 & 0.79 & 0.71 & 0.08 \\
\hline 279.70 & 36.25 & 91.75 & 0.80 & 0.73 & 0.07 \\
\hline 279.90 & 36.28 & 89.10 & 0.81 & 0.73 & 0.09 \\
\hline 280.45 & 36.36 & 91.20 & 0.81 & 0.74 & 0.07 \\
\hline 280.85 & 36.41 & 91.74 & 0.81 & 0.75 & 0.07 \\
\hline 281.40 & 36.49 & 91.53 & 0.81 & 0.75 & 0.07 \\
\hline 281.95 & 36.56 & 89.71 & 0.81 & 0.73 & 0.08 \\
\hline 282.35 & 36.62 & 91.18 & 0.81 & 0.74 & 0.07 \\
\hline 282.90 & 36.69 & 88.61 & 0.81 & 0.72 & 0.09 \\
\hline 283.45 & 36.77 & 89.43 & 0.81 & 0.73 & 0.09 \\
\hline 283.85 & 36.83 & 88.24 & 0.81 & 0.72 & 0.10 \\
\hline 284.20 & 36.88 & 90.97 & 0.83 & 0.75 & 0.07 \\
\hline 285.00 & 36.99 & 78.34 & 0.85 & 0.66 & 0.18 \\
\hline 286.05 & 37.15 & 91.05 & 0.76 & 0.69 & 0.07 \\
\hline 287.15 & 37.32 & 94.19 & 0.76 & 0.71 & 0.04 \\
\hline 287.55 & 37.38 & 93.90 & 0.76 & 0.71 & 0.05 \\
\hline 288.10 & 37.47 & 91.00 & 0.76 & 0.69 & 0.07 \\
\hline 288.65 & 37.55 & 93.96 & 0.76 & 0.71 & 0.05 \\
\hline 289.05 & 37.61 & 94.15 & 0.76 & 0.71 & 0.04 \\
\hline 289.32 & 37.66 & 88.72 & 0.77 & 0.69 & 0.09 \\
\hline 290.15 & 37.78 & 93.64 & 0.72 & 0.67 & 0.05 \\
\hline 290.55 & 37.85 & 92.53 & 0.72 & 0.66 & 0.05 \\
\hline 291.10 & 37.93 & 91.96 & 0.72 & 0.66 & 0.06 \\
\hline 292.05 & 38.08 & 80.66 & 0.72 & 0.58 & 0.14 \\
\hline 292.60 & 38.16 & 83.26 & 0.72 & 0.60 & 0.12 \\
\hline 293.15 & 38.25 & 86.50 & 0.72 & 0.62 & 0.10 \\
\hline 293.55 & 38.31 & 85.68 & 0.70 & 0.60 & 0.10 \\
\hline 294.00 & 38.38 & 87.75 & 0.70 & 0.61 & 0.09 \\
\hline 295.65 & 38.64 & 88.64 & 0.70 & 0.62 & 0.08 \\
\hline 296.20 & 38.72 & 85.99 & 0.70 & 0.60 & 0.10 \\
\hline 296.75 & 38.81 & 88.43 & 0.70 & 0.62 & 0.08 \\
\hline 297.15 & 38.87 & 91.27 & 0.70 & 0.64 & 0.06 \\
\hline 297.70 & 38.96 & 85.31 & 0.70 & 0.60 & 0.10 \\
\hline 298.25 & 39.04 & 87.79 & 0.70 & 0.61 & 0.09 \\
\hline 298.65 & 39.10 & 91.18 & 0.70 & 0.64 & 0.06 \\
\hline 298.97 & 39.15 & 91.30 & 0.73 & 0.67 & 0.06 \\
\hline 299.20 & 39.19 & 88.86 & 0.72 & 0.64 & 0.08 \\
\hline 299.75 & 39.27 & 90.53 & 0.72 & 0.66 & 0.07 \\
\hline
\end{tabular}


APPENDIX A (Continued)

\begin{tabular}{|c|c|c|c|c|c|}
\hline $\begin{array}{l}\text { Depth } \\
\text { (mbsf) }\end{array}$ & $\begin{array}{l}\text { Age } \\
(\mathrm{Ma})\end{array}$ & $\begin{array}{c}\mathrm{CaCO}_{3} \\
(\%)\end{array}$ & $\begin{array}{l}\text { Bulk } \\
\text { MAR }\end{array}$ & $\begin{array}{c}\mathrm{CaCO}_{3} \\
\mathrm{MAR}\end{array}$ & $\begin{array}{c}\text { Non- } \mathrm{CaCO}_{3} \\
\text { MAR }\end{array}$ \\
\hline \multicolumn{6}{|c|}{ Hole $709 \mathrm{C}$ (Cont.): } \\
\hline 300.15 & 39.34 & 89.65 & 0.72 & 0.65 & 0.07 \\
\hline 300.70 & 39.42 & 89.96 & 0.72 & 0.65 & 0.07 \\
\hline 301.25 & 39.51 & 92.84 & 0.72 & 0.67 & 0.05 \\
\hline 301.65 & 39.57 & 89.65 & 0.72 & 0.65 & 0.07 \\
\hline 301.97 & 39.62 & 90.71 & 0.71 & 0.65 & 0.07 \\
\hline 302.20 & 39.66 & 84.89 & 0.72 & 0.62 & 0.11 \\
\hline 302.75 & 39.74 & 89.20 & 0.72 & 0.65 & 0.08 \\
\hline 303.15 & 39.80 & 93.00 & 0.72 & 0.67 & 0.05 \\
\hline 303.70 & 39.89 & 89.79 & 0.72 & 0.65 & 0.07 \\
\hline 304.25 & 39.97 & 89.58 & 0.72 & 0.65 & 0.08 \\
\hline 304.95 & 40.08 & 87.74 & 0.72 & 0.64 & 0.09 \\
\hline 305.35 & 40.14 & 88.34 & 0.72 & 0.64 & 0.08 \\
\hline 305.90 & 40.23 & 86.65 & 0.72 & 0.63 & 0.10 \\
\hline 306.45 & 40.32 & 89.88 & 0.72 & 0.65 & 0.07 \\
\hline 306.85 & 40.38 & 92.06 & 0.72 & 0.67 & 0.06 \\
\hline 307.40 & 40.46 & 90.03 & 0.72 & 0.65 & 0.07 \\
\hline 307.95 & 40.55 & 87.74 & 0.72 & 0.64 & 0.09 \\
\hline 308.35 & 40.61 & 90.59 & 0.72 & 0.66 & 0.07 \\
\hline 308.73 & 40.67 & 91.00 & 0.73 & 0.67 & 0.07 \\
\hline 308.90 & 40.70 & 90.34 & 0.78 & 0.70 & 0.07 \\
\hline 309.45 & 40.78 & 88.95 & 0.78 & 0.69 & 0.09 \\
\hline 309.85 & 40.84 & 91.50 & 0.78 & 0.71 & 0.07 \\
\hline 310.40 & 40.93 & 88.23 & 0.78 & 0.68 & 0.09 \\
\hline 310.95 & 41.01 & 84.91 & 0.78 & 0.66 & 0.12 \\
\hline 311.35 & 41.08 & 89.22 & 0.78 & 0.69 & 0.08 \\
\hline 311.73 & 41.14 & 90.92 & 0.82 & 0.74 & 0.07 \\
\hline 311.90 & 41.16 & 89.69 & 0.77 & 0.69 & 0.08 \\
\hline 312.45 & 41.25 & 92.01 & 0.77 & 0.71 & 0.06 \\
\hline 312.85 & 41.31 & 90.47 & 0.77 & 0.70 & 0.07 \\
\hline 315.05 & 41.65 & 87.28 & 0.77 & 0.67 & 0.10 \\
\hline 315.60 & 41.74 & 85.70 & 0.77 & 0.66 & 0.11 \\
\hline 316.15 & 41.82 & 87.90 & 0.77 & 0.68 & 0.09 \\
\hline 316.55 & 41.88 & 85.85 & 0.77 & 0.66 & 0.11 \\
\hline 317.10 & 41.97 & 88.20 & 0.77 & 0.68 & 0.09 \\
\hline 317.65 & 42.05 & 89.35 & 0.77 & 0.69 & 0.08 \\
\hline 318.05 & 42.12 & 89.29 & 0.77 & 0.69 & 0.08 \\
\hline 318.60 & 42.20 & 89.28 & 0.77 & 0.69 & 0.08 \\
\hline 319.04 & 42.27 & 91.03 & 0.72 & 0.66 & 0.06 \\
\hline 319.05 & 42.27 & 89.94 & 0.76 & 0.68 & 0.08 \\
\hline 319.15 & 42.29 & 91.19 & 0.78 & 0.71 & 0.07 \\
\hline 319.55 & 42.35 & 90.30 & 0.78 & 0.70 & 0.08 \\
\hline 320.10 & 42.43 & 83.40 & 0.78 & 0.65 & 0.13 \\
\hline 320.65 & 42.52 & 92.92 & 0.78 & 0.72 & 0.06 \\
\hline 321.05 & 42.58 & 92.39 & 0.78 & 0.72 & 0.06 \\
\hline 321.43 & 42.64 & 92.59 & 0.78 & 0.72 & 0.06 \\
\hline 321.45 & 42.64 & 93.28 & 0.80 & 0.74 & 0.05 \\
\hline 321.60 & 42.67 & 88.29 & 0.75 & 0.67 & 0.09 \\
\hline 322.15 & 42.75 & 90.38 & 0.75 & 0.68 & 0.07 \\
\hline 322.55 & 42.82 & 82.32 & 0.75 & 0.62 & 0.13 \\
\hline 323.65 & 42.99 & 94.17 & 0.75 & 0.71 & 0.04 \\
\hline 324.68 & 43.15 & 83.89 & 0.75 & 0.63 & 0.12 \\
\hline 325.22 & 43.23 & 85.40 & 0.75 & 0.64 & 0.11 \\
\hline 325.75 & 43.31 & 91.08 & 0.75 & 0.69 & 0.07 \\
\hline 326.15 & 43.37 & 87.05 & 0.75 & 0.66 & 0.10 \\
\hline 326.44 & 43.42 & 81.51 & 0.71 & 0.58 & 0.13 \\
\hline 326.53 & 43.43 & 84.95 & 0.72 & 0.61 & 0.11 \\
\hline 326.71 & 43.46 & 84.56 & 0.72 & 0.61 & 0.11 \\
\hline 327.25 & 43.55 & 91.01 & 0.72 & 0.66 & 0.06 \\
\hline 327.65 & 43.61 & 86.16 & 0.72 & 0.62 & 0.10 \\
\hline 328.20 & 43.69 & 83.08 & 0.72 & 0.60 & 0.12 \\
\hline 328.80 & 43.79 & 84.04 & 0.72 & 0.61 & 0.12 \\
\hline 329.15 & 43.84 & 83.61 & 0.72 & 0.60 & 0.12 \\
\hline 329.70 & 43.93 & 87.98 & 0.72 & 0.63 & 0.09 \\
\hline 330.25 & 44.01 & 88.52 & 0.72 & 0.64 & 0.08 \\
\hline 330.70 & 44.08 & 83.63 & 0.72 & 0.60 & 0.12 \\
\hline 330.90 & 44.11 & 86.11 & 0.73 & 0.63 & 0.10 \\
\hline 330.92 & 44.11 & 83.46 & 0.69 & 0.58 & 0.11 \\
\hline 331.20 & 44.16 & 83.47 & 0.71 & 0.59 & 0.12 \\
\hline 331.78 & 44.25 & 87.29 & 0.71 & 0.62 & 0.09 \\
\hline 332.19 & 44.31 & 85.42 & 0.71 & 0.61 & 0.10 \\
\hline 332.70 & 44.39 & 85.50 & 0.71 & 0.61 & 0.10 \\
\hline 333.34 & 44.49 & 86.67 & 0.71 & 0.62 & 0.09 \\
\hline 334.35 & 44.65 & 86.13 & 0.71 & 0.61 & 0.10 \\
\hline 334.90 & 44.73 & 84.64 & 0.71 & 0.60 & 0.11 \\
\hline 335.45 & 44.82 & 86.74 & 0.71 & 0.62 & 0.09 \\
\hline 335.85 & 44.88 & 86.57 & 0.71 & 0.62 & 0.10 \\
\hline
\end{tabular}

APPENDIX A (Continued)

\begin{tabular}{|c|c|c|c|c|c|}
\hline $\begin{array}{l}\text { Depth } \\
\text { (mbsf) }\end{array}$ & $\begin{array}{l}\text { Age } \\
(\mathrm{Ma})\end{array}$ & $\begin{array}{c}\mathrm{CaCO}_{3} \\
(\%)\end{array}$ & $\begin{array}{l}\text { Bulk } \\
\text { MAR }\end{array}$ & $\begin{array}{c}\mathrm{CaCO}_{3} \\
\mathrm{MAR}\end{array}$ & $\begin{array}{c}\text { Non- } \mathrm{CaCO}_{3} \\
\text { MAR }\end{array}$ \\
\hline \multicolumn{6}{|c|}{ Hole $709 \mathrm{C}$ (Cont.): } \\
\hline 336.40 & 44.97 & 83.95 & 0.71 & 0.60 & 0.11 \\
\hline 336.52 & 44.98 & 85.73 & 0.73 & 0.63 & 0.10 \\
\hline 336.55 & 44.99 & 82.46 & 0.75 & 0.62 & 0.13 \\
\hline 336.95 & 45.05 & 85.50 & 0.74 & 0.63 & 0.11 \\
\hline 337.35 & 45.11 & 87.10 & 0.74 & 0.65 & 0.10 \\
\hline 337.90 & 45.20 & 88.38 & 0.74 & 0.65 & 0.09 \\
\hline 338.45 & 45.28 & 87.19 & 0.74 & 0.65 & 0.09 \\
\hline 338.85 & 45.35 & 86.18 & 0.74 & 0.64 & 0.10 \\
\hline 344.14 & 46.17 & 80.91 & 0.74 & 0.60 & 0.14 \\
\hline 344.70 & 46.25 & 82.01 & 0.74 & 0.61 & 0.13 \\
\hline 345.25 & 46.34 & 82.84 & 0.74 & 0.61 & 0.13 \\
\hline 345.58 & 46.39 & 78.56 & 0.74 & 0.58 & 0.16 \\
\hline 346.11 & 46.47 & 81.16 & 0.73 & 0.59 & 0.14 \\
\hline 346.20 & 46.49 & 80.42 & 0.71 & 0.57 & 0.14 \\
\hline 346.75 & 46.57 & 76.89 & 0.71 & 0.54 & 0.16 \\
\hline 347.15 & 46.64 & 79.46 & 0.71 & 0.56 & 0.14 \\
\hline 347.70 & 46.72 & 74.90 & 0.71 & 0.53 & 0.18 \\
\hline 348.25 & 46.81 & 83.65 & 0.71 & 0.59 & 0.12 \\
\hline 348.66 & 46.87 & 75.71 & 0.71 & 0.53 & 0.17 \\
\hline 349.20 & 46.95 & 78.65 & 0.71 & 0.55 & 0.15 \\
\hline 350.15 & 47.10 & 78.49 & 0.71 & 0.55 & 0.15 \\
\hline 350.57 & 47.17 & 81.68 & 0.68 & 0.56 & 0.13 \\
\hline 350.70 & 47.19 & 86.38 & 0.70 & 0.60 & 0.09 \\
\hline 351.25 & 47.27 & 81.66 & 0.70 & 0.57 & 0.13 \\
\hline 351.65 & 47.33 & 78.51 & 0.70 & 0.55 & 0.15 \\
\hline 352.27 & 47.43 & 84.82 & 0.70 & 0.59 & 0.11 \\
\hline 352.75 & 47.50 & 84.75 & 0.70 & 0.59 & 0.11 \\
\hline 352.91 & 47.53 & 89.49 & 0.71 & 0.63 & 0.07 \\
\hline 353.15 & 47.57 & 84.69 & 0.71 & 0.60 & 0.11 \\
\hline
\end{tabular}

Hole 710A:

$\begin{array}{rlllll}0.25 & 0.03 & 84.58 & 0.73 & 0.62 & 0.11 \\ 1.35 & 0.15 & 84.91 & 0.73 & 0.62 & 0.11 \\ 1.75 & 0.19 & 81.02 & 0.73 & 0.59 & 0.14 \\ 2.30 & 0.25 & 65.91 & 0.73 & 0.48 & 0.25 \\ 2.85 & 0.31 & 81.42 & 0.73 & 0.60 & 0.14 \\ 3.25 & 0.35 & 76.25 & 0.73 & 0.56 & 0.17 \\ 3.80 & 0.41 & 83.35 & 0.73 & 0.61 & 0.12 \\ 4.35 & 0.47 & 82.39 & 0.73 & 0.60 & 0.13 \\ 4.75 & 0.51 & 82.42 & 0.73 & 0.60 & 0.13 \\ 5.02 & 0.54 & 81.49 & 0.73 & 0.60 & 0.14 \\ 5.30 & 0.57 & 73.99 & 0.70 & 0.51 & 0.18 \\ 5.85 & 0.63 & 85.30 & 0.70 & 0.59 & 0.10 \\ 6.25 & 0.67 & 79.94 & 0.70 & 0.56 & 0.14 \\ 6.80 & 0.73 & 77.95 & 0.70 & 0.54 & 0.15 \\ 7.35 & 0.79 & 75.72 & 0.70 & 0.53 & 0.17 \\ 7.75 & 0.84 & 83.00 & 0.70 & 0.58 & 0.12 \\ 8.08 & 0.87 & 70.40 & 0.66 & 0.46 & 0.19 \\ 8.30 & 0.89 & 78.79 & 0.73 & 0.57 & 0.15 \\ 8.85 & 0.95 & 82.85 & 0.73 & 0.60 & 0.12 \\ 9.75 & 1.05 & 75.55 & 0.73 & 0.55 & 0.18 \\ 10.30 & 1.11 & 76.60 & 0.73 & 0.56 & 0.17 \\ 11.60 & 1.25 & 78.91 & 0.80 & 0.63 & 0.17 \\ 11.80 & 1.27 & 86.77 & 0.79 & 0.68 & 0.10 \\ 12.35 & 1.33 & 74.75 & 0.79 & 0.59 & 0.20 \\ 12.75 & 1.37 & 78.77 & 0.79 & 0.62 & 0.17 \\ 13.30 & 1.43 & 80.79 & 0.79 & 0.64 & 0.15 \\ 13.85 & 1.49 & 84.19 & 0.79 & 0.66 & 0.12 \\ 14.25 & 1.54 & 85.63 & 0.79 & 0.68 & 0.11 \\ 14.60 & 1.57 & 85.01 & 0.78 & 0.66 & 0.12 \\ 14.80 & 1.60 & 79.25 & 1.13 & 0.89 & 0.23 \\ 15.35 & 1.65 & 85.51 & 1.13 & 0.96 & 0.16 \\ 15.75 & 1.69 & 79.50 & 1.13 & 0.89 & 0.23 \\ 16.30 & 1.73 & 83.47 & 1.13 & 0.94 & 0.19 \\ 16.85 & 1.77 & 78.99 & 1.13 & 0.89 & 0.24 \\ 17.25 & 1.80 & 86.25 & 1.13 & 0.97 & 0.15 \\ 17.60 & 1.82 & 79.28 & 1.12 & 0.89 & 0.23 \\ 17.80 & 1.84 & 79.20 & 1.12 & 0.89 & 0.23 \\ 18.35 & 1.88 & 86.82 & 1.12 & 0.97 & 0.15 \\ 18.75 & 1.91 & 83.34 & 1.12 & 0.93 & 0.19 \\ 19.45 & 2.41 & 82.59 & 0.97 & 0.80 & 0.17 \\ 19.80 & 2.44 & 80.61 & 0.97 & 0.78 & 0.19 \\ 20.00 & 2.46 & 68.08 & 0.90 & 0.61 & 0.29 \\ 20.55 & 2.51 & 79.77 & 0.90 & 0.72 & 0.18 \\ 20.95 & 2.54 & 78.49 & 0.90 & 0.71 & 0.19\end{array}$


APPENDIX A (Continued)

\begin{tabular}{|c|c|c|c|c|c|}
\hline $\begin{array}{l}\text { Depth } \\
\text { (mbsf) }\end{array}$ & $\begin{array}{l}\text { Age } \\
(\mathrm{Ma})\end{array}$ & $\begin{array}{c}\mathrm{CaCO}_{3} \\
(\%)\end{array}$ & $\begin{array}{l}\text { Bulk } \\
\text { MAR }\end{array}$ & $\begin{array}{c}\mathrm{CaCO}_{3} \\
\mathrm{MAR}\end{array}$ & $\begin{array}{c}\text { Non- } \mathrm{CaCO}_{3} \\
\text { MAR }\end{array}$ \\
\hline \multicolumn{6}{|c|}{ Hole $710 \mathrm{~A}$ (Cont.): } \\
\hline 21.50 & 2.59 & 82.73 & 0.90 & 0.74 & 0.16 \\
\hline 21.89 & 2.62 & 79.31 & 0.90 & 0.71 & 0.19 \\
\hline 22.45 & 2.67 & 70.93 & 0.90 & 0.64 & 0.26 \\
\hline 22.80 & 2.70 & 74.95 & 0.83 & 0.62 & 0.21 \\
\hline 22.95 & 2.71 & 78.28 & 0.81 & 0.63 & 0.17 \\
\hline 23.55 & 2.77 & 74.29 & 0.81 & 0.60 & 0.21 \\
\hline 29.05 & 3.74 & 74.99 & 0.75 & 0.56 & 0.19 \\
\hline 29.60 & 3.79 & 69.83 & 0.75 & 0.52 & 0.23 \\
\hline 30.15 & 3.84 & 67.85 & 0.75 & 0.51 & 0.24 \\
\hline 30.55 & 3.88 & 72.93 & 0.75 & 0.55 & 0.20 \\
\hline 30.90 & 3.91 & 75.34 & 0.73 & 0.55 & 0.18 \\
\hline 31.10 & 3.93 & 74.39 & 0.77 & 0.57 & 0.20 \\
\hline 31.65 & 3.98 & 77.60 & 0.77 & 0.60 & 0.17 \\
\hline 32.05 & 4.01 & 65.21 & 0.77 & 0.50 & 0.27 \\
\hline 32.60 & 4.06 & 67.15 & 0.77 & 0.52 & 0.25 \\
\hline 33.15 & 4.12 & 76.35 & 0.77 & 0.59 & 0.18 \\
\hline 33.55 & 4.15 & 75.15 & 0.77 & 0.58 & 0.19 \\
\hline 33.90 & 4.18 & 76.61 & 0.77 & 0.59 & 0.18 \\
\hline 34.10 & 4.20 & 70.57 & 0.77 & 0.54 & 0.23 \\
\hline 34.65 & 4.25 & 77.25 & 0.77 & 0.59 & 0.18 \\
\hline 35.05 & 4.29 & 77.19 & 0.77 & 0.59 & 0.18 \\
\hline 35.60 & 4.34 & 76.29 & 0.77 & 0.59 & 0.18 \\
\hline 36.15 & 4.39 & 82.27 & 0.77 & 0.63 & 0.14 \\
\hline 36.55 & 4.43 & 75.12 & 0.77 & 0.58 & 0.19 \\
\hline 36.90 & 4.46 & 76.85 & 0.81 & 0.63 & 0.19 \\
\hline 37.10 & 4.48 & 68.72 & 0.79 & 0.54 & 0.25 \\
\hline 37.65 & 4.53 & 78.80 & 0.79 & 0.62 & 0.17 \\
\hline 38.05 & 4.57 & 82.51 & 0.79 & 0.65 & 0.14 \\
\hline 48.15 & 5.50 & 81.84 & 0.79 & 0.64 & 0.14 \\
\hline 48.70 & 5.55 & 78.98 & 0.79 & 0.62 & 0.17 \\
\hline 49.25 & 5.60 & 76.71 & 0.79 & 0.60 & 0.18 \\
\hline 49.54 & 5.63 & 72.40 & 0.79 & 0.57 & 0.22 \\
\hline 50.00 & 5.67 & 71.37 & 0.76 & 0.54 & 0.22 \\
\hline 50.09 & 5.68 & 72.13 & 0.83 & 0.60 & 0.23 \\
\hline 50.64 & 5.73 & 68.62 & 0.83 & 0.57 & 0.26 \\
\hline 51.04 & 5.76 & 79.93 & 0.83 & 0.66 & 0.17 \\
\hline 51.70 & 5.83 & 70.96 & 0.83 & 0.59 & 0.24 \\
\hline 52.14 & 5.87 & 74.24 & 0.83 & 0.62 & 0.21 \\
\hline 52.40 & 5.89 & 78.56 & 0.83 & 0.65 & 0.18 \\
\hline 53.00 & 5.95 & 83.50 & 0.90 & 0.75 & 0.15 \\
\hline 53.13 & 5.96 & 79.99 & 0.95 & 0.76 & 0.19 \\
\hline 53.35 & 5.98 & 78.31 & 0.95 & 0.75 & 0.21 \\
\hline 54.04 & 6.04 & 76.14 & 0.95 & 0.73 & 0.23 \\
\hline 54.59 & 6.09 & 75.54 & 0.95 & 0.72 & 0.23 \\
\hline 55.14 & 6.14 & 75.11 & 0.95 & 0.72 & 0.24 \\
\hline 55.54 & 6.18 & 85.93 & 0.95 & 0.82 & 0.13 \\
\hline 56.00 & 6.22 & 88.70 & 1.01 & 0.89 & 0.11 \\
\hline 56.09 & 6.23 & 80.82 & 1.01 & 0.82 & 0.19 \\
\hline 56.64 & 6.28 & 83.27 & 1.01 & 0.84 & 0.17 \\
\hline 57.04 & 6.32 & 81.34 & 1.01 & 0.82 & 0.19 \\
\hline 57.75 & 6.38 & 70.95 & 1.01 & 0.72 & 0.29 \\
\hline 58.30 & 6.43 & 75.08 & 1.01 & 0.76 & 0.25 \\
\hline 58.85 & 6.48 & 81.88 & 1.01 & 0.83 & 0.18 \\
\hline 59.25 & 6.52 & 79.35 & 1.01 & 0.80 & 0.21 \\
\hline 59.60 & 6.55 & 80.65 & 1.01 & 0.81 & 0.20 \\
\hline 59.80 & 6.57 & 82.44 & 0.95 & 0.79 & 0.17 \\
\hline 60.35 & 6.62 & 80.49 & 0.95 & 0.77 & 0.19 \\
\hline 60.75 & 6.66 & 85.21 & 0.95 & 0.81 & 0.14 \\
\hline 61.30 & 6.71 & 81.37 & 0.95 & 0.78 & 0.18 \\
\hline 61.85 & 6.76 & 80.94 & 0.95 & 0.77 & 0.18 \\
\hline 62.25 & 6.80 & 78.11 & 0.95 & 0.75 & 0.21 \\
\hline 62.60 & 6.83 & 80.48 & 0.90 & 0.72 & 0.18 \\
\hline 62.80 & 6.85 & 73.96 & 0.97 & 0.72 & 0.25 \\
\hline 63.35 & 6.90 & 85.31 & 0.97 & 0.83 & 0.14 \\
\hline 63.75 & 6.94 & 81.57 & 0.97 & 0.79 & 0.18 \\
\hline 63.82 & 6.94 & 83.16 & 1.04 & 0.87 & 0.18 \\
\hline 64.30 & 6.99 & 85.88 & 0.99 & 0.85 & 0.14 \\
\hline 64.85 & 7.04 & 85.65 & 0.99 & 0.85 & 0.14 \\
\hline 65.25 & 7.07 & 85.38 & 0.99 & 0.84 & 0.14 \\
\hline 65.60 & 7.11 & 88.02 & 0.93 & 0.82 & 0.11 \\
\hline 65.80 & 7.13 & 82.51 & 0.97 & 0.80 & 0.17 \\
\hline 66.35 & 7.18 & 86.58 & 0.97 & 0.84 & 0.13 \\
\hline 67.35 & 7.27 & 88.66 & 0.97 & 0.86 & 0.11 \\
\hline 67.70 & 7.30 & 88.66 & 1.00 & 0.88 & 0.11 \\
\hline 67.90 & 7.32 & 86.05 & 0.92 & 0.79 & 0.13 \\
\hline
\end{tabular}

APPENDIX A (Continued)

\begin{tabular}{|c|c|c|c|c|c|}
\hline $\begin{array}{l}\text { Depth } \\
\text { (mbsf) }\end{array}$ & $\begin{array}{l}\text { Age } \\
\text { (Ma) }\end{array}$ & $\begin{array}{c}\mathrm{CaCO}_{3} \\
(\%)\end{array}$ & $\begin{array}{l}\text { Bulk } \\
\text { MAR }\end{array}$ & $\begin{array}{c}\mathrm{CaCO}_{3} \\
\mathrm{MAR}\end{array}$ & $\begin{array}{c}\text { Non- } \mathrm{CaCO}_{3} \\
\text { MAR }\end{array}$ \\
\hline \multicolumn{6}{|c|}{ Hole $710 \mathrm{~A}$ (Cont.): } \\
\hline 68.45 & 7.37 & 86.58 & 0.92 & 0.80 & 0.12 \\
\hline 68.85 & 7.41 & 78.76 & 0.92 & 0.73 & 0.20 \\
\hline 69.20 & 7.44 & 74.91 & 0.85 & 0.63 & 0.21 \\
\hline 69.40 & 7.46 & 76.03 & 0.86 & 0.66 & 0.21 \\
\hline 69.95 & 7.51 & 69.01 & 0.86 & 0.60 & 0.27 \\
\hline 70.35 & 7.55 & 74.01 & 0.86 & 0.64 & 0.22 \\
\hline 70.90 & 7.60 & 64.86 & 0.86 & 0.56 & 0.30 \\
\hline 71.45 & 7.65 & 61.89 & 0.86 & 0.53 & 0.33 \\
\hline 71.85 & 7.68 & 50.22 & 0.86 & 0.43 & 0.43 \\
\hline 74.45 & 7.94 & 69.85 & 0.45 & 0.32 & 0.14 \\
\hline 74.85 & 8.01 & 68.96 & 0.45 & 0.31 & 0.14 \\
\hline 75.20 & 8.08 & 70.64 & 0.46 & 0.33 & 0.14 \\
\hline 75.40 & 8.11 & 69.37 & 0.44 & 0.30 & 0.13 \\
\hline 75.95 & 8.21 & 74.70 & 0.44 & 0.32 & 0.11 \\
\hline 76.85 & 8.37 & 70.35 & 0.44 & 0.31 & 0.13 \\
\hline 77.95 & 8.56 & 72.22 & 0.44 & 0.31 & 0.12 \\
\hline 78.35 & 8.63 & 68.88 & 0.44 & 0.30 & 0.14 \\
\hline 78.70 & 8.69 & 71.15 & 0.41 & 0.29 & 0.12 \\
\hline 78.90 & 8.73 & 69.58 & 0.41 & 0.28 & 0.12 \\
\hline 79.45 & 8.82 & 66.44 & 0.41 & 0.27 & 0.14 \\
\hline 79.85 & 8.89 & 63.21 & 0.41 & 0.26 & 0.15 \\
\hline 80.95 & 9.12 & 45.57 & 0.34 & 0.15 & 0.18 \\
\hline 81.35 & 9.21 & 53.19 & 0.34 & 0.18 & 0.16 \\
\hline 81.90 & 9.32 & 57.55 & 0.34 & 0.19 & 0.14 \\
\hline 82.45 & 9.44 & 46.35 & 0.34 & 0.16 & 0.18 \\
\hline 82.85 & 9.52 & 62.46 & 0.34 & 0.21 & 0.13 \\
\hline 83.23 & 9.60 & 51.68 & 0.38 & 0.20 & 0.18 \\
\hline 83.40 & 9.64 & 52.11 & 0.38 & 0.20 & 0.18 \\
\hline 83.72 & 9.71 & 58.08 & 0.38 & 0.22 & 0.16 \\
\hline 84.35 & 9.84 & 33.79 & 0.38 & 0.13 & 0.25 \\
\hline 85.85 & 10.16 & 71.90 & 0.38 & 0.27 & 0.11 \\
\hline 86.45 & 10.29 & 59.10 & 0.38 & 0.22 & 0.16 \\
\hline 87.00 & 10.40 & 30.53 & 0.38 & 0.12 & 0.26 \\
\hline 87.55 & 10.52 & 42.96 & 0.38 & 0.16 & 0.22 \\
\hline 88.30 & 10.68 & 69.96 & 0.43 & 0.30 & 0.13 \\
\hline 88.50 & 10.72 & 56.22 & 0.43 & 0.24 & 0.19 \\
\hline 89.05 & 10.84 & 68.68 & 0.43 & 0.29 & 0.13 \\
\hline 89.45 & 10.92 & 48.95 & 0.43 & 0.21 & 0.22 \\
\hline 90.00 & 11.04 & 42.33 & 0.43 & 0.18 & 0.25 \\
\hline 90.55 & 11.15 & 40.22 & 0.43 & 0.17 & 0.25 \\
\hline 90.95 & 11.24 & 30.04 & 0.43 & 0.13 & 0.30 \\
\hline 91.33 & 11.32 & 64.77 & 0.43 & 0.28 & 0.15 \\
\hline 91.50 & 11.35 & 57.18 & 0.43 & 0.24 & 0.18 \\
\hline 92.45 & 11.56 & 56.62 & 0.44 & 0.25 & 0.19 \\
\hline 97.15 & 13.90 & 81.54 & 0.71 & 0.58 & 0.13 \\
\hline 98.10 & 14.03 & 64.33 & 0.71 & 0.46 & 0.25 \\
\hline 98.65 & 14.10 & 81.55 & 0.71 & 0.58 & 0.13 \\
\hline 99.05 & 14.15 & 83.28 & 0.71 & 0.59 & 0.12 \\
\hline 99.38 & 14.20 & 74.57 & 0.74 & 0.55 & 0.19 \\
\hline 102.05 & 14.55 & 66.10 & 0.83 & 0.55 & 0.28 \\
\hline 104.65 & 14.89 & 77.89 & 0.83 & 0.65 & 0.18 \\
\hline 105.05 & 14.94 & 76.24 & 0.83 & 0.63 & 0.20 \\
\hline 105.75 & 15.11 & 79.24 & 0.39 & 0.31 & 0.08 \\
\hline 106.30 & 15.27 & 55.14 & 0.39 & 0.21 & 0.17 \\
\hline 106.85 & 15.42 & 61.60 & 0.39 & 0.24 & 0.15 \\
\hline 107.25 & 15.53 & 51.42 & 0.39 & 0.20 & 0.19 \\
\hline 107.60 & 15.63 & 73.37 & 0.43 & 0.32 & 0.12 \\
\hline 107.80 & 15.69 & 73.06 & 0.44 & 0.32 & 0.12 \\
\hline 108.35 & 15.84 & 64.32 & 0.44 & 0.28 & 0.16 \\
\hline 108.75 & 15.95 & 57.21 & 0.44 & 0.25 & 0.19 \\
\hline 110.25 & 16.38 & 60.00 & 0.25 & 0.15 & 0.10 \\
\hline 110.60 & 16.55 & 71.57 & 0.25 & 0.18 & 0.07 \\
\hline 110.80 & 16.65 & 67.61 & 0.25 & 0.17 & 0.08 \\
\hline 111.35 & 16.92 & 62.20 & 0.25 & 0.16 & 0.10 \\
\hline 111.75 & 17.11 & 54.60 & 0.25 & 0.14 & 0.11 \\
\hline 112.30 & 17.38 & 63.85 & 0.25 & 0.16 & 0.09 \\
\hline 113.60 & 18.02 & 76.88 & 0.24 & 0.19 & 0.06 \\
\hline 113.80 & 18.12 & 74.60 & 0.25 & 0.19 & 0.06 \\
\hline 114.35 & 18.39 & 67.14 & 0.25 & 0.17 & 0.08 \\
\hline 114.75 & 18.58 & 73.29 & 0.25 & 0.18 & 0.07 \\
\hline 115.35 & 18.88 & 67.96 & 0.25 & 0.17 & 0.08 \\
\hline 115.45 & 18.93 & 69.68 & 0.25 & 0.18 & 0.08 \\
\hline 116.00 & 19.20 & 65.75 & 0.25 & 0.17 & 0.09 \\
\hline 116.95 & 19.66 & 72.91 & 0.25 & 0.18 & 0.07 \\
\hline 117.30 & 19.84 & 78.76 & 0.26 & 0.20 & 0.05 \\
\hline
\end{tabular}


APPENDIX A (Continued)

\begin{tabular}{|c|c|c|c|c|c|}
\hline $\begin{array}{l}\text { Depth } \\
\text { (mbsf) }\end{array}$ & $\begin{array}{l}\text { Age } \\
(\mathrm{Ma})\end{array}$ & $\begin{array}{c}\mathrm{CaCO}_{3} \\
(\%)\end{array}$ & $\begin{array}{l}\text { Bulk } \\
\text { MAR }\end{array}$ & $\begin{array}{c}\mathrm{CaCO}_{3} \\
\mathrm{MAR}^{-}\end{array}$ & $\begin{array}{c}\text { Non- } \mathrm{CaCO}_{3} \\
\text { MAR }\end{array}$ \\
\hline \multicolumn{6}{|c|}{ Hole 710A (Cont.): } \\
\hline 117.50 & 19.93 & 76.57 & 0.25 & 0.19 & 0.06 \\
\hline 118.05 & 20.20 & 74.79 & 0.25 & 0.19 & 0.06 \\
\hline 118.45 & 20.40 & 74.64 & 0.25 & 0.19 & 0.06 \\
\hline 119.00 & 20.67 & 75.64 & 0.25 & 0.19 & 0.06 \\
\hline 119.55 & 20.94 & 68.53 & 0.25 & 0.17 & 0.08 \\
\hline 119.95 & 21.14 & 72.31 & 0.25 & 0.18 & 0.07 \\
\hline 120.30 & 21.24 & 68.94 & 0.47 & 0.32 & 0.15 \\
\hline 120.50 & 21.29 & 69.35 & 0.45 & 0.31 & 0.14 \\
\hline 121.05 & 21.43 & 78.07 & 0.45 & 0.35 & 0.10 \\
\hline 121.45 & 21.53 & 81.49 & 0.45 & 0.37 & 0.08 \\
\hline 122.00 & 21.67 & 72.51 & 0.45 & 0.33 & 0.12 \\
\hline 122.55 & 21.81 & 77.23 & 0.45 & 0.35 & 0.10 \\
\hline 122.95 & 21.91 & 70.54 & 0.45 & 0.32 & 0.13 \\
\hline 123.30 & 22.00 & 82.67 & 0.44 & 0.36 & 0.08 \\
\hline 123.50 & 22.05 & 68.07 & 0.40 & 0.27 & 0.13 \\
\hline 124.05 & 22.19 & 81.98 & 0.40 & 0.33 & 0.07 \\
\hline 124.45 & 22.29 & 78.50 & 0.40 & 0.32 & 0.09 \\
\hline 125.15 & 22.42 & 65.68 & 0.63 & 0.41 & 0.22 \\
\hline 125.70 & 22.51 & 80.22 & 0.63 & 0.50 & 0.12 \\
\hline 126.65 & 22.67 & 79.49 & 0.63 & 0.50 & 0.13 \\
\hline 127.20 & 22.76 & 64.17 & 0.63 & 0.40 & 0.23 \\
\hline 128.15 & 22.91 & 86.23 & 0.63 & 0.54 & 0.09 \\
\hline 128.70 & 23.00 & 86.58 & 0.63 & 0.54 & 0.08 \\
\hline 128.79 & 23.01 & 70.38 & 0.63 & 0.44 & 0.19 \\
\hline 130.75 & 23.33 & 88.74 & 0.63 & 0.56 & 0.07 \\
\hline 131.15 & 23.40 & 90.78 & 0.63 & 0.57 & 0.06 \\
\hline 131.70 & 23.49 & 89.52 & 0.63 & 0.56 & 0.07 \\
\hline 132.20 & 23.57 & 82.96 & 0.63 & 0.52 & 0.11 \\
\hline 132.25 & 23.58 & 92.76 & 0.63 & 0.58 & 0.05 \\
\hline 132.55 & 23.62 & 92.82 & 0.63 & 0.58 & 0.05 \\
\hline 132.65 & 23.64 & 91.16 & 0.63 & 0.57 & 0.06 \\
\hline 133.20 & 23.73 & 89.12 & 0.63 & 0.56 & 0.07 \\
\hline 133.75 & 23.82 & 91.34 & 0.63 & 0.57 & 0.05 \\
\hline 134.15 & 23.88 & 92.44 & 0.63 & 0.58 & 0.05 \\
\hline 134.70 & 23.97 & 85.94 & 0.63 & 0.54 & 0.09 \\
\hline 134.76 & 23.98 & 91.98 & 0.58 & 0.53 & 0.05 \\
\hline 135.25 & 24.06 & 91.23 & 0.57 & 0.52 & 0.05 \\
\hline 135.65 & 24.13 & 89.42 & 0.57 & 0.51 & 0.06 \\
\hline 136.20 & 24.22 & 86.00 & 0.57 & 0.49 & 0.08 \\
\hline 136.51 & 24.27 & 90.64 & 0.57 & 0.52 & 0.05 \\
\hline 137.15 & 24.37 & 86.47 & 0.57 & 0.50 & 0.08 \\
\hline 137.38 & 24.41 & 87.08 & 0.57 & 0.49 & 0.07 \\
\hline 137.70 & 24.46 & 83.31 & 0.59 & 0.50 & 0.10 \\
\hline 138.25 & 24.55 & 92.51 & 0.59 & 0.55 & 0.04 \\
\hline 138.65 & 24.62 & 91.73 & 0.59 & 0.55 & 0.05 \\
\hline 139.08 & 24.69 & 83.67 & 0.59 & 0.50 & 0.10 \\
\hline 139.34 & 24.73 & 74.35 & 0.59 & 0.44 & 0.15 \\
\hline 142.35 & 25.21 & 92.51 & 0.73 & 0.67 & 0.05 \\
\hline 142.90 & 25.29 & 81.41 & 0.73 & 0.59 & 0.13 \\
\hline 143.45 & 25.36 & 94.17 & 0.73 & 0.68 & 0.04 \\
\hline 143.85 & 25.41 & 92.54 & 0.73 & 0.67 & 0.05 \\
\hline 144.07 & 25.44 & 93.09 & 0.76 & 0.71 & 0.05 \\
\hline 144.40 & 25.49 & 90.34 & 0.74 & 0.67 & 0.07 \\
\hline 144.95 & 25.56 & 92.89 & 0.74 & 0.69 & 0.05 \\
\hline 145.35 & 25.61 & 93.94 & 0.74 & 0.70 & 0.05 \\
\hline 145.90 & 25.69 & 89.84 & 0.74 & 0.67 & 0.08 \\
\hline 146.45 & 25.76 & 90.60 & 0.74 & 0.67 & 0.07 \\
\hline 146.85 & 25.81 & 91.86 & 0.74 & 0.68 & 0.06 \\
\hline 147.17 & 25.85 & 91.85 & 0.74 & 0.68 & 0.06 \\
\hline 147,40 & 25.89 & 90.47 & 0.74 & 0.67 & 0.07 \\
\hline 147.95 & 25.96 & 90.25 & 0.74 & 0.67 & 0.07 \\
\hline 148.35 & 26.01 & 91.62 & 0.74 & 0.68 & 0.06 \\
\hline 148.90 & 26.08 & 88.61 & 0.74 & 0.66 & 0.08 \\
\hline 149.06 & 26.11 & 93.19 & 0.74 & 0.69 & 0.05 \\
\hline 152.05 & 26.50 & 92.61 & 0.74 & 0.69 & 0.05 \\
\hline 152.60 & 26.58 & 87.58 & 0.74 & 0.65 & 0.09 \\
\hline 153.15 & 26.65 & 89.93 & 0.74 & 0.67 & 0.07 \\
\hline 153.55 & 26.70 & 90.46 & 0.74 & 0.67 & 0.07 \\
\hline 153.77 & 26.73 & 90.54 & 0.73 & 0.66 & 0.07 \\
\hline 154.10 & 26.78 & 88.73 & 0.74 & 0.66 & 0.08 \\
\hline 154.65 & 26.85 & 90.65 & 0.74 & 0.67 & 0.07 \\
\hline 155.05 & 26.90 & 92.27 & 0.74 & 0.69 & 0.06 \\
\hline 155.60 & 26.98 & 86.26 & 0.74 & 0.64 & 0.10 \\
\hline 156.15 & 27.05 & 90.32 & 0.74 & 0.67 & 0.07 \\
\hline 156.55 & 27.10 & 89.37 & 0.74 & 0.67 & 0.08 \\
\hline
\end{tabular}

APPENDIX A (Continued)

\begin{tabular}{|c|c|c|c|c|c|}
\hline $\begin{array}{l}\text { Depth } \\
\text { (mbsf) }\end{array}$ & $\begin{array}{l}\text { Age } \\
(\mathrm{Ma})\end{array}$ & $\underset{(\%)}{\mathrm{CaCO}_{3}}$ & $\begin{array}{l}\text { Bulk } \\
\text { MAR }\end{array}$ & $\begin{array}{c}\mathrm{CaCO}_{3} \\
\mathrm{MAR}\end{array}$ & $\begin{array}{c}\text { Non-CaCO } \\
\text { MAR }\end{array}$ \\
\hline \multicolumn{6}{|c|}{ Hole $710 \mathrm{~A}$ (Cont.): } \\
\hline 157.10 & 27.18 & 86.55 & 0.74 & 0.64 & 0.10 \\
\hline 157.65 & 27.25 & 91.79 & 0.74 & 0.68 & 0.06 \\
\hline 158.05 & 27.30 & 91.60 & 0.74 & 0.68 & 0.06 \\
\hline 158.17 & 27.32 & 91.52 & 0.76 & 0.69 & 0.06 \\
\hline 158.32 & 27.34 & 91.71 & 0.76 & 0.70 & 0.06 \\
\hline 158.60 & 27.38 & 89.07 & 0.76 & 0.68 & 0.08 \\
\hline 159.15 & 27.45 & 90.60 & 0.76 & 0.69 & 0.07 \\
\hline 159.55 & 27.50 & 91.67 & 0.76 & 0.70 & 0.06 \\
\hline 160.10 & 27.57 & 89.54 & 0.76 & 0.68 & 0.08 \\
\hline 160.65 & 27.65 & 91.79 & 0.76 & 0.70 & 0.06 \\
\hline 161.65 & 27.78 & 92.34 & 0.76 & 0.70 & 0.06 \\
\hline 162.20 & 27.85 & 91.83 & 0.76 & 0.70 & 0.06 \\
\hline 162.75 & 27.93 & 93.35 & 0.76 & 0.71 & 0.05 \\
\hline 163.15 & 27.98 & 92.17 & 0.76 & 0.70 & 0.06 \\
\hline 163.45 & 28.02 & 89.88 & 0.76 & 0.68 & 0.08 \\
\hline 163.70 & 28.05 & 89.93 & 0.74 & 0.67 & 0.07 \\
\hline 164.25 & 28.13 & 87.73 & 0.74 & 0.65 & 0.09 \\
\hline 164.65 & 28.18 & 88.68 & 0.74 & 0.66 & 0.08 \\
\hline 165.20 & 28.25 & 88.96 & 0.83 & 0.74 & 0.09 \\
\hline 166.15 & 28.36 & 87.89 & 0.83 & 0.73 & 0.10 \\
\hline 166.70 & 28.43 & 90.30 & 0.83 & 0.75 & 0.08 \\
\hline 166.77 & 28.43 & 91.50 & 0.81 & 0.74 & 0.07 \\
\hline 167.25 & 28.49 & 91.65 & 0.81 & 0.74 & 0.07 \\
\hline 167.65 & 28.54 & 88.65 & 0.81 & 0.71 & 0.09 \\
\hline 168.20 & 28.60 & 89.35 & 0.81 & 0.72 & 0.09 \\
\hline 171.35 & 28.98 & 90.14 & 0.81 & 0.73 & 0.08 \\
\hline 171.90 & 29.05 & 84.35 & 0.81 & 0.68 & 0.13 \\
\hline 172.45 & 29.11 & 90.30 & 0.81 & 0.73 & 0.08 \\
\hline 172.85 & 29.16 & 89.71 & 0.81 & 0.72 & 0.08 \\
\hline 172.91 & 29.17 & 90.91 & 0.81 & 0.73 & 0.07 \\
\hline 173.40 & 29.22 & 87.79 & 0.80 & 0.70 & 0.10 \\
\hline 173.95 & 29.29 & 90.21 & 0.80 & 0.72 & 0.08 \\
\hline 174.90 & 29.40 & 87.74 & 0.80 & 0.70 & 0.10 \\
\hline 175.45 & 29.47 & 89.20 & 0.80 & 0.71 & 0.09 \\
\hline 175.85 & 29.52 & 88.37 & 0.80 & 0.71 & 0.09 \\
\hline 176.40 & 29.58 & 86.85 & 0.80 & 0.69 & 0.10 \\
\hline 176.95 & 29.65 & 86.64 & 0.80 & 0.69 & 0.11 \\
\hline 177.35 & 29.69 & 86.72 & 0.80 & 0.69 & 0.11 \\
\hline 177.90 & 29.76 & 86.77 & 0.80 & 0.69 & 0.11 \\
\hline 177.97 & 29.77 & 89.34 & 0.79 & 0.71 & 0.08 \\
\hline 178.45 & 29.83 & 84.62 & 0.81 & 0.68 & 0.12 \\
\hline 178.85 & 29.87 & 91.20 & 0.81 & 0.74 & 0.07 \\
\hline 179.40 & 29.94 & 90.08 & 0.81 & 0.73 & 0.08 \\
\hline 179.95 & 30.00 & 86.86 & 0.81 & 0.70 & 0.11 \\
\hline 181.05 & 30.13 & 86.42 & 0.81 & 0.70 & 0.11 \\
\hline 181.60 & 30.20 & 86.72 & 0.81 & 0.70 & 0.11 \\
\hline 182.15 & 30.27 & 89.58 & 0.81 & 0.72 & 0.08 \\
\hline 182.38 & 30.29 & 89.45 & 0.82 & 0.74 & 0.09 \\
\hline 182.55 & 30.31 & 86.98 & 0.84 & 0.73 & 0.11 \\
\hline 183.10 & 30.38 & 73.40 & 0.84 & 0.61 & 0.22 \\
\hline 183.65 & 30.44 & 73.48 & 0.84 & 0.61 & 0.22 \\
\hline 184.05 & 30.49 & 87.79 & 0.84 & 0.73 & 0.10 \\
\hline 184.60 & 30.56 & 43.95 & 0.84 & 0.37 & 0.47 \\
\hline 185.15 & 30.62 & 89.91 & 0.84 & 0.75 & 0.08 \\
\hline 185.55 & 30.67 & 89.31 & 0.84 & 0.75 & 0.09 \\
\hline 186.10 & 30.74 & 86.46 & 0.84 & 0.72 & 0.11 \\
\hline 186.65 & 30.80 & 91.65 & 0.84 & 0.77 & 0.07 \\
\hline 187.05 & 30.85 & 92.15 & 0.84 & 0.77 & 0.07 \\
\hline 187.29 & 30.88 & 92.01 & 0.85 & 0.78 & 0.07 \\
\hline 187.60 & 30.91 & 86.46 & 0.84 & 0.73 & 0.11 \\
\hline 188.15 & 30.98 & 92.24 & 0.84 & 0.77 & 0.07 \\
\hline 188.55 & 31.03 & 88.60 & 0.84 & 0.74 & 0.10 \\
\hline 189.10 & 31.09 & 82.22 & 0.84 & 0.69 & 0.15 \\
\hline 190.65 & 31.28 & 93.99 & 0.84 & 0.79 & 0.05 \\
\hline 191.20 & 31.34 & 87.85 & 0.84 & 0.74 & 0.10 \\
\hline 191.42 & 31.37 & 93.74 & 0.84 & 0.79 & 0.05 \\
\hline 191.68 & 31.40 & 93.34 & 0.84 & 0.78 & 0.06 \\
\hline 192.23 & 31.47 & 88.98 & 0.84 & 0.75 & 0.09 \\
\hline 192.78 & 31.53 & 93.82 & 0.84 & 0.79 & 0.05 \\
\hline 193.18 & 31.58 & 95.77 & 0.84 & 0.80 & 0.04 \\
\hline 193.73 & 31.64 & 91.63 & 0.84 & 0.77 & 0.07 \\
\hline 194.28 & 31.71 & 95.07 & 0.84 & 0.80 & 0.04 \\
\hline 194.51 & 31.74 & 95.57 & 0.83 & 0.79 & 0.04 \\
\hline 194.68 & 31.76 & 94.04 & 0.84 & 0.79 & 0.05 \\
\hline 195.23 & 31.82 & 89.26 & 0.84 & 0.75 & 0.09 \\
\hline
\end{tabular}


APPENDIX A (Continued)

\begin{tabular}{cccccc}
\hline $\begin{array}{c}\text { Depth } \\
\text { (mbsf) }\end{array}$ & $\begin{array}{c}\text { Age } \\
\text { (Ma) }\end{array}$ & $\begin{array}{c}\mathrm{CaCO}_{3} \\
(\%)\end{array}$ & $\begin{array}{c}\text { Bulk } \\
\text { MAR }\end{array}$ & $\begin{array}{c}\mathrm{CaCO}_{3} \\
\text { MAR }\end{array}$ & $\begin{array}{r}\text { Non-CaC } \\
\text { MAR }\end{array}$ \\
\hline Hole 710A (Cont.): & & & & \\
195.78 & 31.89 & 90.94 & 0.84 & 0.76 & 0.08 \\
196.18 & 31.94 & 93.60 & 0.84 & 0.78 & 0.05 \\
196.73 & 32.00 & 90.26 & 0.84 & 0.75 & 0.08 \\
197.28 & 32.07 & 94.95 & 0.84 & 0.79 & 0.04 \\
197.48 & 32.09 & 93.54 & 0.84 & 0.79 & 0.05 \\
197.65 & 32.11 & 90.66 & 0.83 & 0.75 & 0.08 \\
198.20 & 32.18 & 86.08 & 0.83 & 0.72 & 0.12 \\
198.75 & 32.24 & 92.08 & 0.83 & 0.77 & 0.07 \\
200.35 & 32.43 & 91.73 & 0.83 & 0.76 & 0.07 \\
200.81 & 32.49 & 92.17 & 0.82 & 0.76 & 0.06 \\
200.90 & 32.50 & 90.11 & 0.84 & 0.76 & 0.08 \\
201.45 & 32.56 & 90.68 & 0.84 & 0.77 & 0.08 \\
201.85 & 32.61 & 92.10 & 0.84 & 0.78 & 0.07 \\
202.95 & 32.74 & 91.00 & 0.84 & 0.77 & 0.08 \\
203.35 & 32.79 & 92.62 & 0.84 & 0.78 & 0.06 \\
203.90 & 32.85 & 90.87 & 0.84 & 0.77 & 0.08 \\
204.25 & 32.90 & 93.22 & 0.84 & 0.79 & 0.06 \\
204.70 & 32.95 & 93.36 & 0.87 & 0.81 & 0.06 \\
204.85 & 32.97 & 92.64 & 0.87 & 0.81 & 0.06 \\
204.90 & 32.97 & 87.09 & 0.88 & 0.77 & 0.11 \\
205.10 & 33.00 & 90.67 & 0.92 & 0.83 & 0.09 \\
205.40 & 33.03 & 90.04 & 0.89 & 0.81 & 0.09 \\
205.46 & 33.04 & 93.56 & 0.87 & 0.82 & 0.06 \\
205.68 & 33.07 & 93.44 & 0.89 & 0.83 & 0.06 \\
205.75 & 33.08 & 92.79 & 0.89 & 0.83 & 0.06 \\
206.01 & 33.11 & 90.54 & 0.89 & 0.81 & 0.08
\end{tabular}

Hole 711A:

$\begin{array}{rrrrrl}0.25 & 0.03 & 75.73 & 0.44 & 0.33 & 0.11 \\ 0.80 & 0.09 & 71.04 & 0.44 & 0.31 & 0.13 \\ 1.35 & 0.16 & 40.83 & 0.44 & 0.18 & 0.26 \\ 1.75 & 0.21 & 69.54 & 0.44 & 0.31 & 0.13 \\ 2.12 & 0.25 & 48.24 & 0.44 & 0.21 & 0.23 \\ 2.30 & 0.27 & 44.77 & 0.47 & 0.21 & 0.26 \\ 2.85 & 0.34 & 22.22 & 0.47 & 0.11 & 0.37 \\ 3.25 & 0.38 & 36.20 & 0.47 & 0.17 & 0.30 \\ 3.80 & 0.45 & 56.15 & 0.47 & 0.27 & 0.21 \\ 4.35 & 0.51 & 54.96 & 0.47 & 0.26 & 0.21 \\ 4.75 & 0.56 & 39.79 & 0.47 & 0.19 & 0.29 \\ 5.12 & 0.61 & 61.41 & 0.51 & 0.31 & 0.20 \\ 5.30 & 0.63 & 20.74 & 0.52 & 0.11 & 0.41 \\ 5.85 & 0.69 & 18.46 & 0.52 & 0.10 & 0.42 \\ 6.25 & 0.74 & 16.62 & 0.52 & 0.09 & 0.43 \\ 6.80 & 0.80 & 23.30 & 0.52 & 0.12 & 0.40 \\ 7.35 & 0.87 & 29.96 & 0.52 & 0.15 & 0.36 \\ 7.88 & 0.93 & 62.31 & 0.52 & 0.33 & 0.20 \\ 8.35 & 1.41 & 43.11 & 0.33 & 0.14 & 0.19 \\ 8.70 & 1.47 & 36.49 & 0.33 & 0.12 & 0.21 \\ 9.46 & 1.60 & 36.43 & 0.33 & 0.12 & 0.21 \\ 9.85 & 1.67 & 22.36 & 0.20 & 0.04 & 0.15 \\ 10.40 & 1.84 & 46.72 & 0.20 & 0.09 & 0.10 \\ 10.96 & 2.00 & 37.11 & 0.20 & 0.07 & 0.12 \\ 11.35 & 2.12 & 31.85 & 0.20 & 0.06 & 0.13 \\ 11.70 & 2.22 & 49.21 & 0.18 & 0.09 & 0.09 \\ 11.90 & 2.28 & 37.91 & 0.17 & 0.06 & 0.10 \\ 12.46 & 2.45 & 19.90 & 0.17 & 0.03 & 0.13 \\ 12.85 & 2.56 & 25.36 & 0.17 & 0.04 & 0.12 \\ 17.95 & 4.07 & 4.30 & 0.14 & 0.01 & 0.14 \\ 18.50 & 4.24 & 1.61 & 0.14 & 0.00 & 0.14 \\ 19.05 & 4.40 & 5.32 & 0.14 & 0.01 & 0.14 \\ 19.45 & 4.52 & 13.88 & 0.14 & 0.02 & 0.12 \\ 19.80 & 4.62 & 10.15 & 0.14 & 0.01 & 0.12 \\ 20.00 & 4.68 & 9.88 & 0.27 & 0.03 & 0.25 \\ 20.55 & 4.81 & 0.79 & 0.27 & 0.00 & 0.27 \\ 20.95 & 4.86 & 0.87 & 0.27 & 0.00 & 0.27 \\ 21.50 & 4.94 & 1.70 & 0.27 & 0.00 & 0.27 \\ 22.05 & 5.02 & 0.89 & 0.27 & 0.00 & 0.27 \\ 22.45 & 5.08 & 1.27 & 0.27 & 0.00 & 0.27 \\ 22.80 & 5.13 & 1.04 & 0.27 & 0.00 & 0.26 \\ 23.00 & 5.16 & 4.93 & 0.31 & 0.02 & 0.29 \\ 23.95 & 5.29 & 8.25 & 0.31 & 0.03 & 0.28 \\ 24.50 & 5.37 & 9.88 & 0.31 & 0.03 & 0.28 \\ 25.05 & 5.45 & 4.12 & 0.31 & 0.01 & 0.30 \\ 25.45 & 5.51 & 14.17 & 0.31 & 0.04 & 0.26 \\ 25.80 & 5.56 & 23.52 & 0.35 & 0.08 & 0.27\end{array}$

APPENDIX A (Continued)

\begin{tabular}{|c|c|c|c|c|c|}
\hline $\begin{array}{l}\text { Depth } \\
\text { (mbsf) }\end{array}$ & $\begin{array}{l}\text { Age } \\
\text { (Ma) }\end{array}$ & $\begin{array}{c}\mathrm{CaCO}_{3} \\
(\%)\end{array}$ & $\begin{array}{l}\text { Bulk } \\
\text { MAR }\end{array}$ & $\begin{array}{c}\mathrm{CaCO}_{3} \\
\mathrm{MAR}\end{array}$ & $\begin{array}{c}\text { Non-CaCO } \\
\text { MAR }\end{array}$ \\
\hline \multicolumn{6}{|c|}{ Hole $711 \mathrm{~A}$ (Cont.): } \\
\hline 26.55 & 5.66 & 8.10 & 0.31 & 0.03 & 0.29 \\
\hline 26.92 & 5.72 & 6.64 & 0.31 & 0.02 & 0.29 \\
\hline 27.55 & 5.81 & 12.65 & 0.31 & 0.04 & 0.27 \\
\hline 28.65 & 5.96 & 9.31 & 0.31 & 0.03 & 0.29 \\
\hline 29.40 & 6.07 & 20.50 & 0.28 & 0.06 & 0.22 \\
\hline 29.60 & 6.10 & 21.55 & 0.28 & 0.06 & 0.22 \\
\hline 30.15 & 6.18 & 10.68 & 0.28 & 0.03 & 0.25 \\
\hline 30.55 & 6.24 & 13.01 & 0.28 & 0.04 & 0.25 \\
\hline 31.10 & 6.31 & 31.93 & 0.28 & 0.09 & 0.19 \\
\hline 31.65 & 6.39 & 38.66 & 0.28 & 0.11 & 0.17 \\
\hline 32.05 & 6.45 & 19.88 & 0.28 & 0.06 & 0.23 \\
\hline 32.40 & 6.50 & 14.22 & 0.29 & 0.04 & 0.25 \\
\hline 33.15 & 6.61 & 23.90 & 0.39 & 0.09 & 0.30 \\
\hline 33.55 & 6.66 & 19.78 & 0.39 & 0.08 & 0.31 \\
\hline 34.10 & 6.78 & 37.88 & 0.21 & 0.08 & 0.13 \\
\hline 34.65 & 6.92 & 18.35 & 0.21 & 0.04 & 0.18 \\
\hline 35.60 & 7.17 & 45.65 & 0.25 & 0.12 & 0.14 \\
\hline 36.15 & 7.31 & 42.06 & 0.25 & 0.11 & 0.15 \\
\hline 36.55 & 7.41 & 42.06 & 0.25 & 0.11 & 0.15 \\
\hline 37.15 & 7.57 & 33.26 & 0.25 & 0.08 & 0.17 \\
\hline 37.70 & 7.71 & 29.37 & 0.25 & 0.07 & 0.18 \\
\hline 38.25 & 7.85 & 19.08 & 0.25 & 0.05 & 0.21 \\
\hline 38.65 & 7.95 & 27.34 & 0.25 & 0.07 & 0.18 \\
\hline 39.00 & 8.04 & 6.64 & 0.24 & 0.02 & 0.22 \\
\hline 39.20 & 8.10 & 1.40 & 0.27 & 0.00 & 0.27 \\
\hline 39.75 & 8.29 & 0.02 & 0.10 & 0.00 & 0.10 \\
\hline 40.15 & 8.57 & 0.51 & 0.10 & 0.00 & 0.10 \\
\hline 40.70 & 8.97 & 2.12 & 0.10 & 0.00 & 0.10 \\
\hline 41.25 & 9.36 & 0.98 & 0.10 & 0.00 & 0.10 \\
\hline 41.65 & 9.65 & 5.60 & 0.10 & 0.01 & 0.09 \\
\hline 42.20 & 10.04 & 1.14 & 0.10 & 0.00 & 0.10 \\
\hline 42.75 & 10.43 & 0.12 & 0.10 & 0.00 & 0.10 \\
\hline 43.70 & 11.11 & 1.13 & 0.10 & 0.00 & 0.10 \\
\hline 44.25 & 11.51 & 0.02 & 0.10 & 0.00 & 0.10 \\
\hline 45.00 & 12.04 & 0.84 & 0.11 & 0.00 & 0.11 \\
\hline 45.20 & 12.19 & 2.64 & 0.10 & 0.00 & 0.09 \\
\hline 46.15 & 12.85 & 0.22 & 0.15 & 0.00 & 0.15 \\
\hline 46.85 & 13.18 & 0.48 & 0.15 & 0.00 & 0.15 \\
\hline 47.40 & 13.43 & 2.49 & 0.15 & 0.00 & 0.15 \\
\hline 47.95 & 13.68 & 0.15 & 0.15 & 0.00 & 0.15 \\
\hline 48.35 & 13.87 & 0.29 & 0.15 & 0.00 & 0.15 \\
\hline 49.45 & 14.38 & 19.51 & 0.15 & 0.03 & 0.12 \\
\hline 49.85 & 14.56 & 24.08 & 0.15 & 0.04 & 0.11 \\
\hline 50.95 & 15.07 & 19.51 & 0.15 & 0.03 & 0.12 \\
\hline 51.90 & 15.51 & 6.81 & 0.15 & 0.01 & 0.14 \\
\hline 52.45 & 15.76 & 1.16 & 0.15 & 0.00 & 0.15 \\
\hline 54.90 & 16.89 & 4.00 & 0.15 & 0.01 & 0.14 \\
\hline 55.45 & 17.15 & 5.91 & 0.15 & 0.01 & 0.14 \\
\hline 55.85 & 17.33 & 5.24 & 0.15 & 0.01 & 0.14 \\
\hline 57.10 & 17.91 & 2.93 & 0.15 & 0.00 & 0.15 \\
\hline 57.65 & 18.16 & 1.28 & 0.15 & 0.00 & 0.15 \\
\hline 58.05 & 18.35 & 0.48 & 0.15 & 0.00 & 0.15 \\
\hline 58.40 & 18.51 & 0.59 & 0.13 & 0.00 & 0.12 \\
\hline 58.60 & 18.60 & 2.52 & 0.11 & 0.00 & 0.10 \\
\hline 59.15 & 18.85 & 2.39 & 0.11 & 0.00 & 0.10 \\
\hline 59.55 & 19.04 & 14.09 & 0.11 & 0.01 & 0.09 \\
\hline 60.10 & 19.29 & 2.25 & 0.11 & 0.00 & 0.10 \\
\hline 60.65 & 19.55 & 0.89 & 0.11 & 0.00 & 0.10 \\
\hline 61.05 & 19.73 & 1.15 & 0.11 & 0.00 & 0.10 \\
\hline 61.40 & 19.89 & 1.50 & 0.08 & 0.00 & 0.08 \\
\hline 61.60 & 19.98 & 2.55 & 0.14 & 0.00 & 0.14 \\
\hline 62.15 & 20.24 & 0.24 & 0.14 & 0.00 & 0.14 \\
\hline 62.55 & 20.42 & 13.44 & 0.14 & 0.02 & 0.12 \\
\hline 63.10 & 20.68 & 3.15 & 0.14 & 0.00 & 0.14 \\
\hline 63.65 & 20.93 & 0.39 & 0.14 & 0.00 & 0.14 \\
\hline 64.05 & 21.12 & 0.34 & 0.14 & 0.00 & 0.14 \\
\hline 64.60 & 21.37 & 3.47 & 0.14 & 0.00 & 0.13 \\
\hline 65.15 & 21.62 & 1.88 & 0.14 & 0.00 & 0.14 \\
\hline 66.25 & 22.13 & 6.58 & 0.14 & 0.01 & 0.13 \\
\hline 66.80 & 22.39 & 7.74 & 0.14 & 0.01 & 0.13 \\
\hline 67.35 & 22.64 & 2.68 & 0.14 & 0.00 & 0.14 \\
\hline 78.45 & 25.30 & 73.67 & 0.60 & 0.44 & 0.16 \\
\hline 78.85 & 25.35 & 79.71 & 0.60 & 0.48 & 0.12 \\
\hline 80.35 & 25.56 & 68.32 & 0.60 & 0.41 & 0.19 \\
\hline 80.64 & 25.60 & 84.03 & 0.56 & 0.47 & 0.09 \\
\hline 80.90 & 25.64 & 88.21 & 0.57 & 0.50 & 0.07 \\
\hline
\end{tabular}


APPENDIX A (Continued)

\begin{tabular}{|c|c|c|c|c|c|}
\hline $\begin{array}{l}\text { Depth } \\
\text { (mbsf) }\end{array}$ & $\begin{array}{l}\text { Age } \\
\text { (Ma) }\end{array}$ & $\underset{(\%)}{\mathrm{CaCO}_{3}}$ & $\begin{array}{l}\text { Bulk } \\
\text { MAR }\end{array}$ & $\begin{array}{l}\mathrm{CaCO}_{3} \\
\mathrm{MAR}\end{array}$ & $\underset{\text { MAR }}{\text { Non-CaCO }_{3}}$ \\
\hline \multicolumn{6}{|c|}{ Hole 711A (Cont.): } \\
\hline 81.45 & 25.72 & 86.26 & 0.57 & 0.49 & 0.08 \\
\hline 81.85 & 25.77 & 93.12 & 0.57 & 0.53 & 0.04 \\
\hline 82.40 & 25.85 & 91.40 & 0.57 & 0.52 & 0.05 \\
\hline 83.35 & 25.98 & 87.51 & 0.57 & 0.50 & 0.07 \\
\hline 83.59 & 26.02 & 83.46 & 0.57 & 0.48 & 0.09 \\
\hline 83.90 & 26.06 & 88.12 & 0.62 & 0.55 & 0.07 \\
\hline 84.45 & 26.14 & 92.93 & 0.62 & 0.58 & 0.04 \\
\hline 85.45 & 26.28 & 89.70 & 0.62 & 0.56 & 0.06 \\
\hline 86.00 & 26.36 & 89.02 & 0.62 & 0.56 & 0.07 \\
\hline 86.55 & 26.43 & 92.13 & 0.62 & 0.57 & 0.05 \\
\hline 86.82 & 26.47 & 91.81 & 0.68 & 0.62 & 0.06 \\
\hline 86.95 & 26.49 & 92.47 & 0.64 & 0.59 & 0.05 \\
\hline 87.50 & 26.57 & 85.56 & 0.64 & 0.55 & 0.09 \\
\hline 89.00 & 26.78 & 82.05 & 0.64 & 0.53 & 0.12 \\
\hline 89.55 & 26.85 & 89.48 & 0.64 & 0.57 & 0.07 \\
\hline 89.95 & 26.91 & 89.50 & 0.64 & 0.57 & 0.07 \\
\hline 90.50 & 26.99 & 79.29 & 0.64 & 0.51 & 0.13 \\
\hline 90.66 & 27.01 & 39.58 & 0.61 & 0.24 & 0.37 \\
\hline 91.05 & 27.06 & 88.48 & 0.65 & 0.57 & 0.07 \\
\hline 92.00 & 27.20 & 85.16 & 0.65 & 0.55 & 0.10 \\
\hline 93.50 & 27.41 & 86.38 & 0.65 & 0.56 & 0.09 \\
\hline 93.66 & 27.43 & 88.05 & 0.69 & 0.61 & 0.08 \\
\hline 95.60 & 27.70 & 87.25 & 0.67 & 0.59 & 0.09 \\
\hline 96.76 & 27.86 & 89.52 & 0.66 & 0.59 & 0.07 \\
\hline 97.10 & 27.91 & 86.51 & 0.66 & 0.57 & 0.09 \\
\hline 98.60 & 28.12 & 90.64 & 0.66 & 0.60 & 0.06 \\
\hline 99.55 & 28.26 & 87.46 & 0.62 & 0.55 & 0.08 \\
\hline 100.10 & 28.34 & 73.35 & 0.62 & 0.46 & 0.17 \\
\hline 100.30 & 28.37 & 76.17 & 0.63 & 0.48 & 0.15 \\
\hline 100.65 & 28.43 & 80.20 & 0.64 & 0.51 & 0.13 \\
\hline 101.05 & 28.49 & 78.14 & 0.64 & 0.50 & 0.14 \\
\hline 101.60 & 28.57 & 71.85 & 0.64 & 0.46 & 0.18 \\
\hline 103.07 & 28.79 & 54.56 & 0.64 & 0.35 & 0.29 \\
\hline 104.05 & 28.93 & 87.08 & 0.64 & 0.56 & 0.08 \\
\hline 104.75 & 29.04 & 81.52 & 0.64 & 0.52 & 0.12 \\
\hline 105.30 & 29.12 & 89.35 & 0.64 & 0.57 & 0.07 \\
\hline 105.85 & 29.20 & 78.42 & 0.64 & 0.50 & 0.14 \\
\hline 106.80 & 29.34 & 82.61 & 0.64 & 0.53 & 0.11 \\
\hline 108.30 & 29.57 & 76.95 & 0.64 & 0.49 & 0.15 \\
\hline 108.32 & 29.57 & 79.02 & 0.65 & 0.51 & 0.14 \\
\hline 108.85 & 29.65 & 77.77 & 0.56 & 0.43 & 0.12 \\
\hline 114.45 & 30.48 & 78.95 & 0.56 & 0.44 & 0.12 \\
\hline 115.00 & 30.56 & 80.90 & 0.56 & 0.45 & 0.11 \\
\hline 115.55 & 30.65 & 69.03 & 0.56 & 0.38 & 0.17 \\
\hline 115.95 & 30.71 & 77.72 & 0.56 & 0.43 & 0.12 \\
\hline 116.04 & 30.72 & 79.98 & 0.46 & 0.37 & 0.09 \\
\hline 116.50 & 30.79 & 89.63 & 0.46 & 0.42 & 0.05 \\
\hline 117.05 & 30.87 & 81.60 & 0.46 & 0.38 & 0.09 \\
\hline 117.45 & 30.93 & 71.40 & 0.46 & 0.33 & 0.13 \\
\hline 118.00 & 31.01 & 75.14 & 0.46 & 0.35 & 0.12 \\
\hline 118.55 & 31.09 & 84.69 & 0.46 & 0.39 & 0.07 \\
\hline 118.95 & 31.15 & 37.89 & 0.46 & 0.18 & 0.29 \\
\hline 119.50 & 31.23 & 77.59 & 0.46 & 0.36 & 0.10 \\
\hline 120.05 & 31.32 & 61.19 & 0.46 & 0.28 & 0.18 \\
\hline 120.45 & 31.38 & 76.18 & 0.46 & 0.35 & 0.11 \\
\hline 120.91 & 31.44 & 84.27 & 0.45 & 0.38 & 0.07 \\
\hline 121.00 & 31.46 & 72.22 & 0.55 & 0.40 & 0.15 \\
\hline 121.55 & 31.54 & 80.75 & 0.55 & 0.44 & 0.11 \\
\hline 121.95 & 31.60 & 78.95 & 0.55 & 0.43 & 0.12 \\
\hline 122.50 & 31.68 & 88.39 & 0.55 & 0.49 & 0.06 \\
\hline 122.80 & 31.73 & 92.35 & 0.55 & 0.51 & 0.04 \\
\hline 124.15 & 31.93 & 93.36 & 0.55 & 0.51 & 0.04 \\
\hline 124.70 & 32.01 & 92.18 & 0.55 & 0.51 & 0.04 \\
\hline 125.25 & 32.09 & 90.31 & 0.55 & 0.50 & 0.05 \\
\hline 125.65 & 32.15 & 91.40 & 0.55 & 0.50 & 0.05 \\
\hline 126.20 & 32.23 & 88.44 & 0.55 & 0.49 & 0.06 \\
\hline 126.24 & 32.24 & 91.20 & 0.65 & 0.59 & 0.06 \\
\hline 126.75 & 32.31 & 90.31 & 0.63 & 0.57 & 0.06 \\
\hline 127.15 & 32.37 & 88.71 & 0.63 & 0.56 & 0.07 \\
\hline 127.70 & 32.46 & 88.58 & 0.63 & 0.56 & 0.07 \\
\hline 128.25 & 32.54 & 90.10 & 0.63 & 0.57 & 0.06 \\
\hline 128.65 & 32.60 & 92.40 & 0.63 & 0.58 & 0.05 \\
\hline 129.20 & 32.68 & 93.15 & 0.63 & 0.58 & 0.04 \\
\hline 129.75 & 32.76 & 91.11 & 0.63 & 0.57 & 0.06 \\
\hline 130.15 & 32.82 & 92.63 & 0.63 & 0.58 & 0.05 \\
\hline 130.46 & 32.87 & 92.78 & 0.60 & 0.56 & 0.04 \\
\hline
\end{tabular}

APPENDIX A (Continued)

\begin{tabular}{|c|c|c|c|c|c|}
\hline $\begin{array}{l}\text { Depth } \\
\text { (mbsf) }\end{array}$ & $\begin{array}{l}\text { Age } \\
\text { (Ma) }\end{array}$ & $\begin{array}{c}\mathrm{CaCO}_{3} \\
(\%)\end{array}$ & $\begin{array}{l}\text { Bulk } \\
\text { MAR }\end{array}$ & $\begin{array}{l}\mathrm{CaCO}_{3} \\
\mathrm{MAR}\end{array}$ & $\begin{array}{c}\text { Non- } \mathrm{CaCO}_{3} \\
\text { MAR }\end{array}$ \\
\hline \multicolumn{6}{|c|}{ Hole 711A (Cont.): } \\
\hline 130.70 & 32.90 & 91.28 & 0.60 & 0.55 & 0.05 \\
\hline 131.25 & 32.98 & 87.22 & 0.60 & 0.53 & 0.08 \\
\hline 131.65 & 33.04 & 86.81 & 0.60 & 0.52 & 0.08 \\
\hline 132.19 & 33.12 & 87.48 & 0.60 & 0.53 & 0.08 \\
\hline 133.85 & 33.37 & 91.05 & 0.60 & 0.55 & 0.05 \\
\hline 134.40 & 33.45 & 85.82 & 0.60 & 0.52 & 0.09 \\
\hline 134.95 & 33.54 & 89.85 & 0.60 & 0.54 & 0.06 \\
\hline 135.35 & 33.60 & 88.99 & 0.60 & 0.53 & 0.07 \\
\hline 135.63 & 33.64 & 91.53 & 0.59 & 0.54 & 0.05 \\
\hline 135.90 & 33.68 & 88.63 & 0.59 & 0.52 & 0.07 \\
\hline 136.45 & 33.76 & 89.89 & 0.59 & 0.53 & 0.06 \\
\hline 136.85 & 33.82 & 88.72 & 0.59 & 0.52 & 0.07 \\
\hline 137.40 & 33.90 & 91.57 & 0.59 & 0.54 & 0.05 \\
\hline 137.95 & 33.98 & 88.42 & 0.59 & 0.52 & 0.07 \\
\hline 138.35 & 34.04 & 90.01 & 0.59 & 0.53 & 0.06 \\
\hline 138.90 & 34.12 & 88.17 & 0.59 & 0.52 & 0.07 \\
\hline 139.45 & 34.21 & 87.45 & 0.59 & 0.51 & 0.07 \\
\hline 139.85 & 34.27 & 89.54 & 0.59 & 0.53 & 0.06 \\
\hline 140.36 & 34.34 & 84.25 & 0.58 & 0.49 & 0.09 \\
\hline 140.40 & 34.35 & 82.58 & 0.61 & 0.50 & 0.11 \\
\hline 141.35 & 34.49 & 80.26 & 0.61 & 0.49 & 0.12 \\
\hline 141.90 & 34.57 & 86.47 & 0.61 & 0.53 & 0.08 \\
\hline 143.55 & 34.82 & 88.82 & 0.61 & 0.54 & 0.07 \\
\hline 144.10 & 34.90 & 88.42 & 0.61 & 0.54 & 0.07 \\
\hline 144.65 & 34.98 & 88.49 & 0.61 & 0.54 & 0.07 \\
\hline 145.05 & 35.04 & 64.77 & 0.61 & 0.39 & 0.21 \\
\hline 145.25 & 35.07 & 92.09 & 0.63 & 0.58 & 0.05 \\
\hline 145.60 & 35.12 & 88.09 & 0.71 & 0.62 & 0.08 \\
\hline 146.15 & 35.20 & 89.41 & 0.71 & 0.63 & 0.07 \\
\hline 146.55 & 35.26 & 88.90 & 0.71 & 0.63 & 0.08 \\
\hline 147.10 & 35.35 & 87.98 & 0.71 & 0.62 & 0.09 \\
\hline 147.65 & 35.43 & 90.08 & 0.71 & 0.64 & 0.07 \\
\hline 148.05 & 35.49 & 91.43 & 0.71 & 0.65 & 0.06 \\
\hline 148.60 & 35.57 & 89.92 & 0.71 & 0.64 & 0.07 \\
\hline 149.15 & 35.65 & 92.87 & 0.71 & 0.66 & 0.05 \\
\hline 149.55 & 35.71 & 91.84 & 0.71 & 0.65 & 0.06 \\
\hline 149.77 & 35.74 & 94.63 & 0.79 & 0.74 & 0.04 \\
\hline 150.10 & 35.79 & 90.71 & 0.72 & 0.66 & 0.07 \\
\hline 150.65 & 35.88 & 92.87 & 0.72 & 0.67 & 0.05 \\
\hline 151.05 & 35.93 & 82.20 & 0.72 & 0.60 & 0.13 \\
\hline 151.60 & 36.02 & 88.96 & 0.72 & 0.64 & 0.08 \\
\hline 152.15 & 36.10 & 89.82 & 0.72 & 0.65 & 0.07 \\
\hline 152.55 & 36.16 & 89.38 & 0.72 & 0.65 & 0.08 \\
\hline 153.25 & 36.26 & 90.18 & 0.72 & 0.65 & 0.07 \\
\hline 153.80 & 36.34 & 88.85 & 0.72 & 0.64 & 0.08 \\
\hline 154.35 & 36.43 & 91.41 & 0.72 & 0.66 & 0.06 \\
\hline 154.75 & 36.49 & 85.67 & 0.72 & 0.62 & 0.10 \\
\hline 155.30 & 36.57 & 83.90 & 0.72 & 0.61 & 0.12 \\
\hline 155.85 & 36.65 & 82.67 & 0.72 & 0.60 & 0.13 \\
\hline 156.25 & 36.71 & 72.89 & 0.72 & 0.53 & 0.20 \\
\hline 156.80 & 36.79 & 81.45 & 0.72 & 0.59 & 0.13 \\
\hline 157.35 & 36.87 & 86.84 & 0.72 & 0.63 & 0.10 \\
\hline 157.75 & 36.93 & 81.99 & 0.72 & 0.59 & 0.13 \\
\hline 158.30 & 37.02 & 81.03 & 0.66 & 0.54 & 0.13 \\
\hline 158.85 & 37.11 & 81.45 & 0.66 & 0.54 & 0.12 \\
\hline 159.25 & 37.17 & 84.80 & 0.66 & 0.56 & 0.10 \\
\hline 159.65 & 37.24 & 85.69 & 0.61 & 0.52 & 0.09 \\
\hline 159.80 & 37.26 & 83.56 & 0.55 & 0.46 & 0.09 \\
\hline 160.35 & 37.35 & 88.11 & 0.55 & 0.48 & 0.07 \\
\hline 160.75 & 37.41 & 91.34 & 0.55 & 0.50 & 0.05 \\
\hline 161.30 & 37.50 & 85.70 & 0.55 & 0.47 & 0.08 \\
\hline 161.85 & 37.59 & 87.58 & 0.55 & 0.48 & 0.07 \\
\hline 162.25 & 37.66 & 87.19 & 0.55 & 0.48 & 0.07 \\
\hline 162.95 & 37.77 & 82.15 & 0.55 & 0.45 & 0.10 \\
\hline 163.50 & 37.86 & 86.56 & 0.55 & 0.48 & 0.07 \\
\hline 164.05 & 37.95 & 87.75 & 0.55 & 0.48 & 0.07 \\
\hline 164.45 & 38.02 & 79.59 & 0.55 & 0.44 & 0.11 \\
\hline 164.80 & 38.07 & 75.33 & 0.49 & 0.37 & 0.12 \\
\hline 165.00 & 38.11 & 80.11 & 0.52 & 0.41 & 0.10 \\
\hline 165.55 & 38.20 & 80.30 & 0.52 & 0.41 & 0.10 \\
\hline 165.95 & 38.26 & 90.41 & 0.52 & 0.47 & 0.05 \\
\hline 166.50 & 38.35 & 74.68 & 0.52 & 0.39 & 0.13 \\
\hline 166.78 & 38.40 & 79.28 & 0.52 & 0.41 & 0.11 \\
\hline 167.45 & 38.50 & 85.07 & 0.52 & 0.44 & 0.08 \\
\hline 167.80 & 38.56 & 82.84 & 0.54 & 0.45 & 0.09 \\
\hline 168.00 & 38.59 & 79.98 & 0.39 & 0.31 & 0.08 \\
\hline
\end{tabular}


APPENDIX A (Continued)

\begin{tabular}{|c|c|c|c|c|c|}
\hline $\begin{array}{l}\text { Depth } \\
\text { (mbsf) }\end{array}$ & $\begin{array}{l}\text { Age } \\
\text { (Ma) }\end{array}$ & $\begin{array}{c}\mathrm{CaCO}_{3} \\
(\%)\end{array}$ & $\begin{array}{l}\text { Bulk } \\
\text { MAR }\end{array}$ & $\begin{array}{c}\mathrm{CaCO}_{3} \\
\mathrm{MAR}\end{array}$ & $\begin{array}{c}\text { Non-CaCc } \\
\text { MAR }\end{array}$ \\
\hline \multicolumn{6}{|c|}{ Hole 711A (Cont.): } \\
\hline 168.55 & 38.68 & 84.82 & 0.39 & 0.33 & 0.06 \\
\hline 172.65 & 39.35 & 87.30 & 0.39 & 0.34 & 0.05 \\
\hline 172.81 & 39.38 & 84.87 & 0.39 & 0.33 & 0.06 \\
\hline 173.75 & 39.53 & 65.97 & 0.39 & 0.26 & 0.13 \\
\hline 174.03 & 39.57 & 2.64 & 0.24 & 0.01 & 0.23 \\
\hline 174.14 & 39.59 & 0.29 & 0.25 & 0.00 & 0.25 \\
\hline 174.36 & 39.63 & 3.23 & 0.26 & 0.01 & 0.26 \\
\hline 174.64 & 39.67 & 2.13 & 0.25 & 0.01 & 0.24 \\
\hline 175.18 & 39.76 & 83.82 & 0.28 & 0.23 & 0.05 \\
\hline 175.25 & 39.77 & 86.63 & 0.28 & 0.24 & 0.04 \\
\hline 175.66 & 39.84 & 84.65 & 0.28 & 0.24 & 0.04 \\
\hline 176.20 & 39.93 & 79.91 & 0.28 & 0.22 & 0.06 \\
\hline 176.75 & 40.02 & 84.64 & 0.28 & 0.24 & 0.04 \\
\hline 177.16 & 40.08 & 83.27 & 0.28 & 0.23 & 0.05 \\
\hline 177.70 & 40.17 & 83.62 & 0.28 & 0.23 & 0.05 \\
\hline 178.25 & 40.26 & 83.83 & 0.28 & 0.23 & 0.05 \\
\hline 178.66 & 40.33 & 83.90 & 0.28 & 0.23 & 0.05 \\
\hline 179.20 & 40.41 & 77.47 & 0.28 & 0.22 & 0.06 \\
\hline 179.75 & 40.50 & 80.55 & 0.28 & 0.23 & 0.05 \\
\hline 180.16 & 40.57 & 78.22 & 0.28 & 0.22 & 0.06 \\
\hline 180.70 & 40.66 & 81.78 & 0.28 & 0.23 & 0.05 \\
\hline 181.25 & 40.75 & 79.37 & 0.28 & 0.22 & 0.06 \\
\hline 182.35 & 40.93 & 72.74 & 0.28 & 0.20 & 0.08 \\
\hline 182.90 & 41.02 & 70.22 & 0.28 & 0.20 & 0.08 \\
\hline 183.45 & 41.11 & 63.44 & 0.28 & 0.18 & 0.10 \\
\hline 183.85 & 41.17 & 63.57 & 0.28 & 0.18 & 0.10 \\
\hline 184.20 & 41.23 & 7.86 & 0.31 & 0.02 & 0.29 \\
\hline 184.40 & 41.26 & 2.33 & 0.38 & 0.01 & 0.37 \\
\hline 184.95 & 41.35 & 0.17 & 0.38 & 0.00 & 0.38 \\
\hline 185.35 & 41.41 & 0.20 & 0.38 & 0.00 & 0.38 \\
\hline 185.54 & 41.45 & 1.86 & 0.38 & 0.01 & 0.37 \\
\hline 185.60 & 41.46 & 0.13 & 0.38 & 0.00 & 0.38 \\
\hline 185.85 & 41.50 & 26.84 & 0.38 & 0.10 & 0.28 \\
\hline 187.40 & 41.75 & 77.98 & 0.38 & 0.30 & 0.08 \\
\hline 187.95 & 41.84 & 81.99 & 0.38 & 0.31 & 0.07 \\
\hline 188.35 & 41.90 & 78.41 & 0.38 & 0.30 & 0.08 \\
\hline 188.52 & 41.93 & 79.85 & 0.38 & 0.30 & 0.08 \\
\hline 188.55 & 41.93 & 79.93 & 0.38 & 0.30 & 0.08 \\
\hline 191.95 & 42.49 & 77.25 & 0.38 & 0.29 & 0.09 \\
\hline 192.50 & 42.58 & 79.08 & 0.38 & 0.30 & 0.08 \\
\hline 193.05 & 42.67 & 80.74 & 0.38 & 0.31 & 0.07 \\
\hline 193.45 & 42.73 & 80.17 & 0.38 & 0.31 & 0.08 \\
\hline 193.80 & 42.79 & 79.09 & 0.38 & 0.30 & 0.08 \\
\hline 194.00 & 42.82 & 78.58 & 0.38 & 0.30 & 0.08 \\
\hline 194.55 & 42.91 & 83.30 & 0.38 & 0.32 & 0.06 \\
\hline 194.95 & 42.98 & 79.29 & 0.38 & 0.30 & 0.08 \\
\hline 195.50 & 43.07 & 80.70 & 0.38 & 0.31 & 0.07 \\
\hline 196.05 & 43.15 & 73.89 & 0.38 & 0.28 & 0.10 \\
\hline 196.45 & 43.22 & 71.36 & 0.38 & 0.27 & 0.11 \\
\hline 197.00 & 43.31 & 78.09 & 0.38 & 0.30 & 0.08 \\
\hline 197.31 & 43.36 & 77.30 & 0.38 & 0.29 & 0.09 \\
\hline 198.30 & 43.52 & 90.71 & 0.45 & 0.41 & 0.04 \\
\hline 198.50 & 43.55 & 78.04 & 0.50 & 0.39 & 0.11 \\
\hline 198.81 & 43.60 & 78.93 & 0.50 & 0.39 & 0.10 \\
\hline 201.65 & 44.07 & 69.21 & 0.50 & 0.34 & 0.15 \\
\hline 202.20 & 44.15 & 70.71 & 0.50 & 0.35 & 0.15 \\
\hline 202.75 & 44.24 & 75.53 & 0.50 & 0.38 & 0.12 \\
\hline 203.15 & 44.31 & 74.06 & 0.50 & 0.37 & 0.13 \\
\hline 203.50 & 44.37 & 78.38 & 0.55 & 0.43 & 0.12 \\
\hline 203.70 & 44.40 & 78.95 & 0.54 & 0.43 & 0.11 \\
\hline 204.25 & 44.49 & 76.82 & 0.54 & 0.42 & 0.13 \\
\hline 204.65 & 44.55 & 76.37 & 0.54 & 0.41 & 0.13 \\
\hline 205.20 & 44.64 & 77.22 & 0.54 & 0.42 & 0.12 \\
\hline 205.75 & 44.73 & 77.19 & 0.54 & 0.42 & 0.12 \\
\hline 206.15 & 44,80 & 69.58 & 0.54 & 0.38 & 0.16 \\
\hline 206.50 & 44.85 & 78.38 & 0.54 & 0.42 & 0.12 \\
\hline 206.70 & 44.89 & 79.16 & 0.54 & 0.43 & 0.11 \\
\hline 211.35 & 45.64 & 74.63 & 0.54 & 0.40 & 0.14 \\
\hline 211.90 & 45.73 & 71.96 & 0.54 & 0.39 & 0.15 \\
\hline 212.45 & 45.82 & 73.69 & 0.54 & 0.40 & 0.14 \\
\hline 212.85 & 45.89 & 52.94 & 0.54 & 0.29 & 0.25 \\
\hline 213.20 & 45.94 & 66.81 & 0.55 & 0.37 & 0.18 \\
\hline 213.40 & 45.98 & 67.37 & 0.50 & 0.34 & 0.16 \\
\hline 213.95 & 46.07 & 68.56 & 0.50 & 0.35 & 0.16 \\
\hline 214.35 & 46.13 & 65.64 & 0.50 & 0.33 & 0.17 \\
\hline 214.90 & 46.22 & 57.62 & 0.50 & 0.29 & 0.21 \\
\hline
\end{tabular}

APPENDIX A (Continued)

\begin{tabular}{|c|c|c|c|c|c|}
\hline $\begin{array}{l}\text { Depth } \\
\text { (mbsf) }\end{array}$ & $\begin{array}{l}\text { Age } \\
\text { (Ma) }\end{array}$ & $\begin{array}{c}\mathrm{CaCO}_{3} \\
(\%)\end{array}$ & $\begin{array}{l}\text { Bulk } \\
\text { MAR }\end{array}$ & $\underset{\mathrm{MAR}}{\mathrm{CaCO}_{3}}$ & $\begin{array}{c}\text { Non- } \mathrm{CaCO}_{3} \\
\text { MAR }\end{array}$ \\
\hline \multicolumn{6}{|c|}{ Hole 711A (Cont.): } \\
\hline 215.45 & 46.31 & 69.55 & 0.50 & 0.35 & 0.15 \\
\hline 215.85 & 46.37 & 68.23 & 0.50 & 0.34 & 0.16 \\
\hline 216.20 & 46.43 & 64.31 & 0.46 & 0.30 & 0.16 \\
\hline 216.40 & 46.46 & 62.11 & 0.46 & 0.28 & 0.17 \\
\hline 216.95 & 46.55 & 72.03 & 0.46 & 0.33 & 0.13 \\
\hline 217.35 & 46.62 & 66.86 & 0.46 & 0.30 & 0.15 \\
\hline 217.90 & 46.71 & 54.52 & 0.46 & 0.25 & 0.21 \\
\hline 218.45 & 46.80 & 68.08 & 0.46 & 0.31 & 0.15 \\
\hline 218.85 & 46.86 & 69.67 & 0.46 & 0.32 & 0.14 \\
\hline 219.15 & 46.91 & 54.95 & 0.45 & 0.25 & 0.20 \\
\hline 219.40 & 46.95 & 67.99 & 0.52 & 0.36 & 0.17 \\
\hline 219.95 & 47.04 & 75.22 & 0.52 & 0.39 & 0.13 \\
\hline 220.90 & 47.18 & 74.97 & 0.52 & 0.39 & 0.13 \\
\hline 221.30 & 47.24 & 71.46 & 0.52 & 0.37 & 0.15 \\
\hline 221.50 & 47.27 & 70.51 & 0.52 & 0.37 & 0.15 \\
\hline 222.05 & 47.36 & 69.07 & 0.52 & 0.36 & 0.16 \\
\hline 222.40 & 47.41 & 65.55 & 0.52 & 0.34 & 0.18 \\
\hline 223.00 & 47.50 & 68.09 & 0.52 & 0.36 & 0.17 \\
\hline 223.55 & 47.59 & 68.70 & 0.52 & 0.36 & 0.16 \\
\hline 223.90 & 47.64 & 68.48 & 0.52 & 0.36 & 0.17 \\
\hline 224.30 & 47.70 & 68.04 & 0.52 & 0.36 & 0.17 \\
\hline 224.50 & 47.73 & 69.05 & 0.52 & 0.36 & 0.16 \\
\hline 224.67 & 47.76 & 66.86 & 0.52 & 0.35 & 0.17 \\
\hline 225.40 & 47.87 & 73.63 & 0.52 & 0.39 & 0.14 \\
\hline 226.00 & 47.96 & 63.93 & 0.52 & 0.34 & 0.19 \\
\hline 226.55 & 48.04 & 71.73 & 0.52 & 0.38 & 0.15 \\
\hline 226.95 & 48.11 & 62.04 & 0.52 & 0.33 & 0.20 \\
\hline 227.30 & 48.16 & 65.65 & 0.57 & 0.37 & 0.20 \\
\hline 227.50 & 48.19 & 69.32 & 0.54 & 0.38 & 0.17 \\
\hline 227.67 & 48.22 & 74.52 & 0.54 & 0.41 & 0.14 \\
\hline 230.55 & 48.66 & 74.53 & 0.54 & 0.41 & 0.14 \\
\hline 231.10 & 48.74 & 73.18 & 0.54 & 0.40 & 0.15 \\
\hline 231.65 & 48.82 & 73.11 & 0.54 & 0.40 & 0.15 \\
\hline 232.05 & 48.88 & 72.84 & 0.54 & 0.40 & 0.15 \\
\hline 232.40 & 48.94 & 67.72 & 0.52 & 0.35 & 0.17 \\
\hline 232.60 & 48.97 & 71.39 & 0.52 & 0.37 & 0.15 \\
\hline 233.15 & 49.05 & 75.79 & 0.52 & 0.39 & 0.13 \\
\hline 233.55 & 49.11 & 73.02 & 0.52 & 0.38 & 0.14 \\
\hline 234.10 & 49.20 & 71.04 & 0.52 & 0.37 & 0.15 \\
\hline 234.65 & 49.28 & 67.13 & 0.52 & 0.35 & 0.17 \\
\hline 235.05 & 49.34 & 61.54 & 0.52 & 0.32 & 0.20 \\
\hline 235.40 & 49.39 & 71.59 & 0.52 & 0.37 & 0.15 \\
\hline 235.60 & 49.43 & 68.21 & 0.52 & 0.35 & 0.16 \\
\hline 236.15 & 49.51 & 69.70 & 0.52 & 0.36 & 0.16 \\
\hline \multicolumn{6}{|l|}{ Hole $711 \mathrm{~B}$ : } \\
\hline 62.06 & 21.40 & 10.93 & 0.16 & 0.02 & 0.14 \\
\hline 66.52 & 23.05 & 63.86 & 0.33 & 0.21 & 0.12 \\
\hline 76.76 & 25.30 & 78.98 & 0.49 & 0.39 & 0.10 \\
\hline \multicolumn{6}{|l|}{ Hole $714 \mathrm{~A}$ : } \\
\hline 0.30 & 0.008 & 81.86 & 3.17 & 2.59 & 0.57 \\
\hline 1.00 & 0.026 & 67.47 & 3.17 & 2.14 & 1.03 \\
\hline 1.80 & 0.046 & 72.56 & 3.17 & 2.30 & 0.87 \\
\hline 2.19 & 0.056 & 67.98 & 3.17 & 2.15 & 1.01 \\
\hline 2.50 & 0.064 & 60.05 & 3.31 & 1.99 & 1.32 \\
\hline 3.10 & 0.079 & 79.41 & 3.31 & 2.63 & 0.68 \\
\hline 3.40 & 0.087 & 80.70 & 3.44 & 2.78 & 0.66 \\
\hline 3.80 & 0.097 & 80.09 & 3.40 & 2.73 & 0.68 \\
\hline 4.60 & 0.118 & 70.81 & 3.40 & 2.41 & 0.99 \\
\hline 5.30 & 0.135 & 71.58 & 3.40 & 2.44 & 0.97 \\
\hline 6.10 & 0.156 & 71.49 & 3.40 & 2.43 & 0.97 \\
\hline 6.80 & 0.174 & 80.78 & 3.37 & 2.72 & 0.65 \\
\hline 7.60 & 0.194 & 73.17 & 3.19 & 2.33 & 0.86 \\
\hline 8.30 & 0.212 & 73.07 & 3.19 & 2.33 & 0.86 \\
\hline 9.10 & 0.233 & 75.81 & 3.19 & 2.42 & 0.77 \\
\hline 9.80 & 0.250 & 74.82 & 3.01 & 2.25 & 0.76 \\
\hline 10.60 & 0.271 & 75.22 & 3.19 & 2.40 & 0.79 \\
\hline 11.30 & 0.289 & 84.10 & 3.37 & 2.83 & 0.54 \\
\hline 12.10 & 0.309 & 84.06 & 3.31 & 2.78 & 0.53 \\
\hline 12.70 & 0.325 & 72.32 & 3.31 & 2.39 & 0.92 \\
\hline 13.00 & 0.332 & 81.05 & 3.25 & 2.63 & 0.62 \\
\hline 13.40 & 0.342 & 80.55 & 3.17 & 2.55 & 0.62 \\
\hline 14.20 & 0.363 & 78.40 & 3.17 & 2.48 & 0.68 \\
\hline 14.90 & 0.381 & 80.67 & 3.17 & 2.56 & 0.61 \\
\hline
\end{tabular}


APPENDIX A (Continued)

\begin{tabular}{|c|c|c|c|c|c|}
\hline $\begin{array}{l}\text { Depth } \\
\text { (mbsf) }\end{array}$ & $\begin{array}{l}\text { Age } \\
(\mathrm{Ma})\end{array}$ & $\begin{array}{c}\mathrm{CaCO}_{3} \\
(\%)\end{array}$ & $\begin{array}{r}\text { Bulk } \\
\text { MAR }\end{array}$ & $\begin{array}{l}\mathrm{CaCO}_{3} \\
\mathrm{MAR}\end{array}$ & $\begin{array}{c}\text { Non- } \mathrm{CaCO}_{3} \\
\text { MAR }\end{array}$ \\
\hline \multicolumn{6}{|c|}{ Hole 714A (Cont.): } \\
\hline 15.70 & 0.401 & 66.56 & 3.17 & 2.11 & 1.06 \\
\hline 16.00 & 0.409 & 73.65 & 3.09 & 2.28 & 0.81 \\
\hline 16.40 & 0.419 & 71.86 & 3.23 & 2.32 & 0.91 \\
\hline 17.20 & 0.440 & 74.78 & 3.23 & 2.41 & 0.81 \\
\hline 17.50 & 0.447 & 80.50 & 3.37 & 2.71 & 0.66 \\
\hline 17.90 & 0.457 & 80.07 & 3.05 & 2.44 & 0.61 \\
\hline 18.70 & 0.478 & 81.31 & 3.05 & 2.48 & 0.57 \\
\hline 19.00 & 0.486 & 83.64 & 3.05 & 2.55 & 0.50 \\
\hline 19.40 & 0.496 & 81.39 & 3.05 & 2.48 & 0.57 \\
\hline 20.20 & 7.63 & 81.84 & 0.97 & 0.79 & 0.18 \\
\hline 20.50 & 7.65 & 88.56 & 0.97 & 0.86 & 0.11 \\
\hline 20.90 & 7.69 & 74.21 & 0.99 & 0.73 & 0.25 \\
\hline 21.70 & 7.75 & 88.99 & 0.99 & 0.88 & 0.11 \\
\hline 22.48 & 7.82 & 77.19 & 0.99 & 0.76 & 0.22 \\
\hline 22.78 & 7.84 & 89.70 & 1.00 & 0.90 & 0.10 \\
\hline 23.18 & 7.88 & 83.34 & 0.99 & 0.83 & 0.17 \\
\hline 23.93 & 7.94 & 85.69 & 0.99 & 0.85 & 0.14 \\
\hline 24.63 & 8.00 & 83.07 & 0.99 & 0.82 & 0.17 \\
\hline 25.43 & 8.06 & 86.62 & 0.99 & 0.86 & 0.13 \\
\hline 25.99 & 8.11 & 87.60 & 0.98 & 0.86 & 0.12 \\
\hline 26.13 & 8.12 & 87.12 & 1.02 & 0.89 & 0.13 \\
\hline 26.93 & 8.19 & 86.14 & 1.02 & 0.88 & 0.14 \\
\hline 27.63 & 8.24 & 69.77 & 1.02 & 0.71 & 0.31 \\
\hline 28.43 & 8.31 & 86.73 & 1.02 & 0.89 & 0.14 \\
\hline 29.01 & 8.36 & 81.60 & 1.06 & 0.87 & 0.20 \\
\hline 29.13 & 8.37 & 81.86 & 1.03 & 0.84 & 0.19 \\
\hline 29.93 & 8.43 & 79.47 & 1.03 & 0.82 & 0.21 \\
\hline 30.63 & 8.49 & 82.98 & 1.03 & 0.85 & 0.17 \\
\hline 31.43 & 8.56 & 83.52 & 1.03 & 0.86 & 0.17 \\
\hline 32.00 & 8.60 & 83.57 & 1.03 & 0.86 & 0.17 \\
\hline 32.70 & 8.66 & 80.71 & 1.03 & 0.83 & 0.20 \\
\hline 33.50 & 8.73 & 77.45 & 1.03 & 0.80 & 0.23 \\
\hline 33.80 & 8.75 & 78.03 & 0.99 & 0.77 & 0.22 \\
\hline 34.20 & 8.79 & 83.38 & 1.00 & 0.84 & 0.17 \\
\hline 35.00 & 8.85 & 86.00 & 1.00 & 0.86 & 0.14 \\
\hline 35.70 & 8.91 & 82.54 & 1.00 & 0.83 & 0.18 \\
\hline 36.50 & 8.98 & 81.74 & 1.00 & 0.82 & 0.18 \\
\hline 36.80 & 9.00 & 79.54 & 1.02 & 0.81 & 0.21 \\
\hline 37.20 & 9.04 & 80.30 & 1.02 & 0.82 & 0.20 \\
\hline 38.00 & 9.10 & 84.61 & 1.02 & 0.86 & 0.16 \\
\hline 38.70 & 9.16 & 80.47 & 1.02 & 0.82 & 0.20 \\
\hline 39.50 & 9.23 & 81.38 & 1.02 & 0.83 & 0.19 \\
\hline 39.80 & 9.25 & 82.67 & 1.02 & 0.84 & 0.18 \\
\hline 40.20 & 9.28 & 75.79 & 1.05 & 0.79 & 0.25 \\
\hline 41.00 & 9.35 & 83.57 & 1.05 & 0.87 & 0.17 \\
\hline 41.70 & 9.41 & 80.77 & 1.05 & 0.84 & 0.20 \\
\hline 42.40 & 9.47 & 82.27 & 1.05 & 0.86 & 0.19 \\
\hline 43.20 & 9.53 & 77.45 & 1.05 & 0.81 & 0.24 \\
\hline 43.50 & 9.56 & 82.88 & 1.08 & 0.89 & 0.18 \\
\hline 43.90 & 9.59 & 73.40 & 1.14 & 0.84 & 0.30 \\
\hline 44.70 & 9.66 & 84.80 & 1.14 & 0.97 & 0.17 \\
\hline 45.40 & 9.71 & 72.14 & 1.14 & 0.82 & 0.32 \\
\hline 46.20 & 9.78 & 84.84 & 1.14 & 0.97 & 0.17 \\
\hline 46.50 & 9.80 & 86.18 & 1.21 & 1.04 & 0.17 \\
\hline 46.90 & 9.84 & 69.82 & 1.18 & 0.82 & 0.36 \\
\hline 47.70 & 9.90 & 83.80 & 1.18 & 0.99 & 0.19 \\
\hline 48.40 & 9.96 & 86.71 & 1.18 & 1.02 & 0.16 \\
\hline 49.20 & 10.03 & 80.99 & 1.18 & 0.95 & 0.22 \\
\hline 49.50 & 10.05 & 82.35 & 1.15 & 0.95 & 0.20 \\
\hline 49.90 & 10.09 & 83.51 & 1.12 & 0.94 & 0.19 \\
\hline 50.70 & 10.15 & 80.09 & 1.12 & 0.90 & 0.22 \\
\hline 51.30 & 10.20 & 85.20 & 1.12 & 0.96 & 0.17 \\
\hline 52.00 & 10.26 & 84.20 & 1.12 & 0.95 & 0.18 \\
\hline 52.80 & 10.33 & 79.70 & 1.12 & 0.90 & 0.23 \\
\hline 52.90 & 10.33 & 74.15 & 1.12 & 0.83 & 0.29 \\
\hline 53.10 & 10.35 & 85.93 & 1.10 & 0.95 & 0.15 \\
\hline 53.12 & 10.35 & 86.18 & 1.04 & 0.90 & 0.14 \\
\hline 53.50 & 10.38 & 79.73 & 1.04 & 0.83 & 0.21 \\
\hline 54.30 & 10.45 & 79.95 & 1.04 & 0.83 & 0.21 \\
\hline 54.40 & 10.46 & 75.93 & 1.04 & 0.79 & 0.25 \\
\hline 55.00 & 10.51 & 86.33 & 1.04 & 0.90 & 0.14 \\
\hline 55.80 & 10.57 & 79.03 & 1.04 & 0.82 & 0.22 \\
\hline 55.90 & 10.58 & 83.10 & 1.04 & 0.86 & 0.18 \\
\hline 56.10 & 10.60 & 71.43 & 0.98 & 0.70 & 0.28 \\
\hline 56.50 & 10.63 & 75.26 & 1.09 & 0.82 & 0.27 \\
\hline 57.30 & 10.70 & 85.53 & 1.09 & 0.93 & 0.16 \\
\hline
\end{tabular}

APPENDIX A (Continued)

\begin{tabular}{|c|c|c|c|c|c|}
\hline $\begin{array}{l}\text { Depth } \\
\text { (mbsf) }\end{array}$ & $\begin{array}{l}\text { Age } \\
(\mathrm{Ma})\end{array}$ & $\begin{array}{c}\mathrm{CaCO}_{3} \\
(\%)\end{array}$ & $\begin{array}{l}\text { Bulk } \\
\text { MAR }\end{array}$ & $\begin{array}{c}\mathrm{CaCO}_{3} \\
\mathrm{MAR}\end{array}$ & $\begin{array}{c}\text { Non- } \mathrm{CaCO}_{3} \\
\text { MAR }\end{array}$ \\
\hline \multicolumn{6}{|c|}{ Hole 714A (Cont.): } \\
\hline 58.00 & 10.76 & 80.76 & 1.09 & 0.88 & 0.21 \\
\hline 58.80 & 10.82 & 76.19 & 1.09 & 0.83 & 0.26 \\
\hline 59.06 & 10.84 & 85.32 & 1.20 & 1.02 & 0.18 \\
\hline 59.50 & 10.88 & 82.22 & 1.13 & 0.93 & 0.20 \\
\hline 60.30 & 10.95 & 84.55 & 1.13 & 0.96 & 0.17 \\
\hline 60.90 & 11.00 & 84.21 & 1.13 & 0.95 & 0.18 \\
\hline 61.60 & 11.05 & 79.19 & 1.13 & 0.90 & 0.24 \\
\hline 62.40 & 11.12 & 84.67 & 1.13 & 0.96 & 0.17 \\
\hline 62.70 & 11.14 & 86.18 & 1.06 & 0.92 & 0.15 \\
\hline 63.10 & 11.18 & 86.43 & 1.06 & 0.91 & 0.14 \\
\hline 63.90 & 11.24 & 84.41 & 1.06 & 0.89 & 0.16 \\
\hline 64.60 & 11.30 & 86.04 & 1.06 & 0.91 & 0.15 \\
\hline 65.40 & 11.37 & 87.55 & 1.06 & 0.93 & 0.13 \\
\hline 65.70 & 11.39 & 87.74 & 1.05 & 0.92 & 0.13 \\
\hline 66.10 & 11.43 & 86.46 & 1.12 & 0.97 & 0.15 \\
\hline 66.90 & 11.49 & 90.60 & 1.12 & 1.02 & 0.11 \\
\hline 67.60 & 11.55 & 88.14 & 1.12 & 0.99 & 0.13 \\
\hline 68.40 & 11.62 & 83.29 & 1.12 & 0.94 & 0.19 \\
\hline 68.70 & 11.64 & 88.61 & 1.20 & 1.06 & 0.14 \\
\hline 69.10 & 11.67 & 82.10 & 1.14 & 0.93 & 0.20 \\
\hline 69.90 & 11.74 & 87.71 & 1.14 & 1.00 & 0.14 \\
\hline 70.50 & 11.79 & 88.65 & 1.14 & 1.01 & 0.13 \\
\hline 71.20 & 11.85 & 87.96 & 1.14 & 1.00 & 0.14 \\
\hline 72.00 & 11.91 & 84.35 & 1.14 & 0.96 & 0.18 \\
\hline 72.30 & 11.94 & 81.26 & 1.08 & 0.87 & 0.20 \\
\hline 72.70 & 11.97 & 84.88 & 1.13 & 0.96 & 0.17 \\
\hline 73.50 & 12.04 & 86.01 & 1.13 & 0.97 & 0.16 \\
\hline 73.95 & 12.08 & 86.58 & 1.18 & 1.03 & 0.16 \\
\hline 74.20 & 12.10 & 82.99 & 1.24 & d.03 & 0.21 \\
\hline 75.00 & 12.16 & 86.42 & 1.24 & 1.07 & 0.17 \\
\hline 80.10 & 12.58 & 86.21 & 1.24 & 1.07 & 0.17 \\
\hline 80.80 & 12.64 & 86.17 & 1.24 & 1.07 & 0.17 \\
\hline 81.60 & 12.71 & 87.50 & 1.24 & 1.08 & 0.15 \\
\hline 81.90 & 12.73 & 86.31 & 1.29 & 1.12 & 0.18 \\
\hline 82.30 & 12.77 & 79.36 & 1.25 & 0.99 & 0.26 \\
\hline 83.10 & 12.83 & 85.21 & 1.25 & 1.06 & 0.18 \\
\hline 83.40 & 12.86 & 94.74 & 1.20 & 1.13 & 0.06 \\
\hline 83.80 & 12.89 & 86.89 & 1.25 & 1.09 & 0.16 \\
\hline 84.60 & 12.96 & 87.08 & 1.25 & 1.09 & 0.16 \\
\hline 85.30 & 13.01 & 88.12 & 1.25 & 1.10 & 0.15 \\
\hline 86.10 & 13.08 & 89.11 & 1.25 & 1.11 & 0.14 \\
\hline 86.40 & 13.10 & 86.68 & 1.31 & 1.13 & 0.17 \\
\hline 86.80 & 13.14 & 89.97 & 1.26 & 1.13 & 0.13 \\
\hline 87.60 & 13.20 & 90.96 & 1.51 & 1.38 & 0.14 \\
\hline 88.30 & 13.25 & 86.52 & 1.51 & 1.31 & 0.20 \\
\hline 89.10 & 13.31 & 91.30 & 1.51 & 1.38 & 0.13 \\
\hline 89.40 & 13.33 & 89.99 & 1.45 & 1.31 & 0.15 \\
\hline 89.80 & 13.35 & 89.85 & 1.43 & 1.29 & 0.15 \\
\hline 90.50 & 13.40 & 90.98 & 1.43 & 1.30 & 0.13 \\
\hline 91.30 & 13.46 & 90.95 & 1.43 & 1.30 & 0.13 \\
\hline 92.00 & 13.51 & 89.03 & 1.43 & 1.27 & 0.16 \\
\hline 92.80 & 13.56 & 90.98 & 1.43 & 1.30 & 0.13 \\
\hline 93.20 & 13.59 & 92.35 & 1.41 & 1.30 & 0.11 \\
\hline 93.50 & 13.61 & 90.08 & 1.35 & 1.22 & 0.13 \\
\hline 94.30 & 13.66 & 88.41 & 1.35 & 1.20 & 0.16 \\
\hline 95.00 & 13.71 & 88.40 & 1.35 & 1.20 & 0.16 \\
\hline 95.80 & 13.77 & 87.61 & 1.35 & 1.18 & 0.17 \\
\hline 96.50 & 13.82 & 86.17 & 1.35 & 1.17 & 0.19 \\
\hline 97.30 & 13.87 & 88.66 & 1.35 & 1.20 & 0.15 \\
\hline 97.52 & 13.89 & 88.21 & 1.29 & 1.14 & 0.15 \\
\hline 98.00 & 13.92 & 92.08 & 1.34 & 1.24 & 0.11 \\
\hline 99.40 & 14.02 & 88.44 & 1.34 & 1.19 & 0.16 \\
\hline 100.10 & 14.06 & 90.60 & 1.34 & 1.22 & 0.13 \\
\hline 100.90 & 14.12 & 85.56 & 1.34 & 1.15 & 0.19 \\
\hline 101.20 & 14.14 & 92.14 & 1.40 & 1.29 & 0.11 \\
\hline 101.60 & 14.17 & 89.47 & 1.41 & 1.26 & 0.15 \\
\hline 102.40 & 14.22 & 90.79 & 1.41 & 1.28 & 0.13 \\
\hline 103.10 & 14.27 & 88.96 & 1.41 & 1.25 & 0.16 \\
\hline 103.90 & 14.32 & 89.42 & 1.41 & 1.26 & 0.15 \\
\hline 104.21 & 14.35 & 94.73 & 1.42 & 1.35 & 0.08 \\
\hline 104.60 & 14.37 & 88.10 & 1.41 & 1.24 & 0.17 \\
\hline 105.40 & 14.43 & 88.50 & 1.41 & 1.25 & 0.16 \\
\hline 105.73 & 14.45 & 89.54 & 1.41 & 1.26 & 0.15 \\
\hline 106.10 & 14.48 & 86.82 & 1.41 & 1.22 & 0.19 \\
\hline 106.90 & 14.53 & 89.84 & 1.41 & 1.27 & 0.14 \\
\hline 107.60 & 14.58 & 88.41 & 1.40 & 1.24 & 0.16 \\
\hline
\end{tabular}


APPENDIX A (Continued)

\begin{tabular}{|c|c|c|c|c|c|}
\hline $\begin{array}{l}\text { Depth } \\
\text { (mbsf) }\end{array}$ & $\begin{array}{l}\text { Age } \\
\text { (Ma) }\end{array}$ & $\begin{array}{c}\mathrm{CaCO}_{3} \\
(\%)\end{array}$ & $\begin{array}{l}\text { Bulk } \\
\text { MAR }\end{array}$ & $\begin{array}{c}\mathrm{CaCO}_{3} \\
\mathrm{MAR}^{-}\end{array}$ & $\begin{array}{c}\text { Non- } \mathrm{CaCO}_{3} \\
\text { MAR }\end{array}$ \\
\hline \multicolumn{6}{|c|}{ Hole 714A (Cont.): } \\
\hline 108.40 & 14.63 & 85.77 & 1.40 & 1.20 & 0.20 \\
\hline 109.00 & 14.68 & 90.25 & 1.40 & 1.27 & 0.14 \\
\hline 109.70 & 14.72 & 87.02 & 1.40 & 1.22 & 0.18 \\
\hline 110.50 & 14.78 & 90.37 & 1.40 & 1.27 & 0.14 \\
\hline 110.78 & 14.80 & 88.10 & 1.41 & 1.24 & 0.17 \\
\hline 111.20 & 14.83 & 92.57 & 1.45 & 1.35 & 0.11 \\
\hline 112.00 & 14.88 & 90.20 & 1.45 & 1.31 & 0.14 \\
\hline 112.70 & 14.93 & 90.84 & 1.45 & 1.32 & 0.13 \\
\hline 113.50 & 14.98 & 90.34 & 1.45 & 1.31 & 0.14 \\
\hline 113.85 & 15.01 & 87.03 & 1.50 & 1.30 & 0.19 \\
\hline 114.20 & 15.03 & 88.21 & 1.43 & 1.26 & 0.17 \\
\hline 115.00 & 15.09 & 91.35 & 1.43 & 1.31 & 0.12 \\
\hline 115.70 & 15.14 & 85.34 & 1.43 & 1.22 & 0.21 \\
\hline 116.50 & 15.19 & 87.46 & 1.43 & 1.25 & 0.18 \\
\hline 117.20 & 15.24 & 87.34 & 1.31 & 1.14 & 0.17 \\
\hline 118.00 & 15.29 & 86.25 & 1.31 & 1.13 & 0.18 \\
\hline 118.70 & 15.34 & 87.73 & 1.31 & 1.15 & 0.16 \\
\hline 119.40 & 15.39 & 87.36 & 1.31 & 1.14 & 0.17 \\
\hline 120.20 & 15.45 & 88.32 & 1.31 & 1.16 & 0.15 \\
\hline 120.53 & 15.47 & 88.81 & 1.25 & 1.11 & 0.14 \\
\hline 120.90 & 15.49 & 86.95 & 1.29 & 1.12 & 0.17 \\
\hline 121.70 & 15.55 & 88.59 & 1.29 & 1.14 & 0.15 \\
\hline 122.40 & 15.60 & 85.99 & 1.29 & 1.11 & 0.18 \\
\hline 123.20 & 15.65 & 85.44 & 1.29 & 1.10 & 0.19 \\
\hline 123.53 & 15.67 & 87.40 & 1.32 & 1.16 & 0.17 \\
\hline 123.90 & 15.70 & 82.54 & 1.33 & 1.10 & 0.23 \\
\hline 124.70 & 15.76 & 88.80 & 1.33 & 1.18 & 0.15 \\
\hline 125.40 & 15.80 & 84.83 & 1.33 & 1.13 & 0.20 \\
\hline 126.20 & 15.86 & 88.38 & 1.33 & 1.18 & 0.15 \\
\hline 126.44 & 15.87 & 85.91 & 1.34 & 1.15 & 0.19 \\
\hline 126.55 & 15.88 & 89.49 & 1.33 & 1.19 & 0.14 \\
\hline 126.90 & 15.91 & 88.42 & 1.33 & 1.18 & 0.15 \\
\hline 127.10 & 15.92 & 79.94 & 1.33 & 1.06 & 0.27 \\
\hline 127.72 & 15.96 & 86.82 & 1.33 & 1.15 & 0.18 \\
\hline 128.60 & 16.02 & 85.30 & 1.33 & 1.13 & 0.20 \\
\hline 129.22 & 16.07 & 87.26 & 1.33 & 1.16 & 0.17 \\
\hline 129.30 & 16.07 & 87.56 & 1.32 & 1.16 & 0.16 \\
\hline 130.10 & 16.13 & 83.56 & 1.37 & 1.14 & 0.22 \\
\hline 130.72 & 16.17 & 86.58 & 1.37 & 1.18 & 0.18 \\
\hline 131.56 & 16.23 & 86.78 & 1.41 & 1.22 & 0.19 \\
\hline 131.60 & 16.23 & 85.69 & 1.42 & 1.21 & 0.20 \\
\hline 132.22 & 16.27 & 87.18 & 1.42 & 1.24 & 0.18 \\
\hline 133.10 & 16.33 & 87.50 & 1.42 & 1.24 & 0.18 \\
\hline 133.72 & 16.38 & 85.20 & 1.42 & 1.21 & 0.21 \\
\hline 134.19 & 16.41 & 89.14 & 1.42 & 1.27 & 0.15 \\
\hline 134.27 & 16.41 & 84.59 & 1.38 & 1.17 & 0.21 \\
\hline 136.70 & 16.58 & 85.44 & 1.38 & 1.18 & 0.20 \\
\hline 137.40 & 16.63 & 83.25 & 1.38 & 1.15 & 0.23 \\
\hline 138.20 & 16.68 & 86.09 & 1.38 & 1.19 & 0.19 \\
\hline 138.90 & 16.73 & 83.35 & 1.38 & 1.15 & 0.23 \\
\hline 139.70 & 16.79 & 78.83 & 1.38 & 1.09 & 0.29 \\
\hline 139.90 & 16.80 & 86.42 & 1.38 & 1.19 & 0.19 \\
\hline 140.40 & 16.84 & 83.26 & 1.36 & 1.13 & 0.23 \\
\hline 141.20 & 16.89 & 80.73 & 1.36 & 1.10 & 0.26 \\
\hline 141.90 & 16.94 & 84.59 & 1.36 & 1.15 & 0.21 \\
\hline 142.70 & 16.99 & 84.44 & 1.32 & 1.12 & 0.21 \\
\hline 143.40 & 17.04 & 83.53 & 1.32 & 1.11 & 0.22 \\
\hline 144.60 & 17.12 & 83.75 & 1.32 & 1.11 & 0.21 \\
\hline 146.40 & 17.25 & 84.82 & 1.32 & 1.12 & 0.20 \\
\hline 147.10 & 17.30 & 85.60 & 1.32 & 1.13 & 0.19 \\
\hline 147.90 & 17.35 & 86.17 & 1.32 & 1.14 & 0.18 \\
\hline 148.52 & 17.39 & 85.22 & 1.26 & 1.08 & 0.19 \\
\hline 148.60 & 17.40 & 85.33 & 1.35 & 1.15 & 0.20 \\
\hline 149.40 & 17.45 & 85.45 & 1.35 & 1.16 & 0.20 \\
\hline 150.10 & 17.50 & 86.50 & 1.35 & 1.17 & 0.18 \\
\hline 150,90 & 17.56 & 87.95 & 1.35 & 1.19 & 0.16 \\
\hline 151.60 & 17.61 & 82.09 & 1.35 & 1.11 & 0.24 \\
\hline 152.08 & 17.64 & 85.96 & 1.44 & 1.24 & 0.20 \\
\hline 152.40 & 17.66 & 87.07 & 1.40 & 1.22 & 0.18 \\
\hline 156.00 & 17.91 & 87.76 & 1.40 & 1.23 & 0.17 \\
\hline 156.70 & 17.96 & 84.35 & 1.40 & 1.18 & 0.22 \\
\hline
\end{tabular}

APPENDIX A (Continued)

\begin{tabular}{|c|c|c|c|c|c|}
\hline $\begin{array}{l}\text { Depth } \\
\text { (mbsf) }\end{array}$ & $\begin{array}{l}\text { Age } \\
\text { (Ma) }\end{array}$ & $\underset{(\%)}{\mathrm{CaCO}_{3}}$ & $\begin{array}{l}\text { Bulk } \\
\text { MAR }\end{array}$ & $\begin{array}{c}\mathrm{CaCO}_{3} \\
\mathrm{MAR}\end{array}$ & $\begin{array}{c}\text { Non- } \mathrm{CaCO}_{3} \\
\text { MAR }\end{array}$ \\
\hline \multicolumn{6}{|c|}{ Hole 714A (Cont.): } \\
\hline 157.50 & 18.01 & 85.69 & 1.40 & 1.20 & 0.20 \\
\hline 158.20 & 18.06 & 78.50 & 1.40 & 1.10 & 0.30 \\
\hline 158.78 & 18.10 & 88.40 & 1.37 & 1.21 & 0.16 \\
\hline 159.00 & 18.11 & 87.42 & 1.39 & 1.21 & 0.17 \\
\hline 159.70 & 18.16 & 81.00 & 1.39 & 1.12 & 0.26 \\
\hline 160.50 & 18.22 & 82.82 & 1.39 & 1.15 & 0.24 \\
\hline 161.20 & 18.27 & 88.14 & 1.39 & 1.22 & 0.16 \\
\hline 161.80 & 18.31 & 82.93 & 1.41 & 1.17 & 0.24 \\
\hline 162.00 & 18.32 & 81.82 & 1.42 & 1.16 & 0.26 \\
\hline 162.70 & 18.37 & 88.80 & 1.42 & 1.26 & 0.16 \\
\hline 163.50 & 18.47 & 88.30 & 0.48 & 0.42 & 0.06 \\
\hline 163.82 & 18.54 & 86.02 & 0.48 & 0.41 & 0.07 \\
\hline 165.60 & 18.90 & 86.51 & 0.48 & 0.41 & 0.06 \\
\hline 166.30 & 19.04 & 84.80 & 0.48 & 0.40 & 0.07 \\
\hline 167.10 & 19.21 & 86.56 & 0.48 & 0.41 & 0.06 \\
\hline 167.32 & 19.25 & 88.01 & 0.48 & 0.42 & 0.06 \\
\hline 167.80 & 19.35 & 85.00 & 0.50 & 0.43 & 0.08 \\
\hline 168.60 & 19.51 & 83.17 & 0.50 & 0.42 & 0.08 \\
\hline 169.30 & 19.66 & 87.44 & 0.50 & 0.44 & 0.06 \\
\hline 170.10 & 19.82 & 85.61 & 0.50 & 0.43 & 0.07 \\
\hline 170.80 & 19.96 & 88.63 & 0.50 & 0.45 & 0.06 \\
\hline 171.60 & 20.13 & 90.78 & 0.50 & 0.46 & 0.05 \\
\hline 171.86 & 20.18 & 88.77 & 0.53 & 0.47 & 0.06 \\
\hline 172.30 & 20.27 & 89.49 & 0.51 & 0.45 & 0.05 \\
\hline 173.10 & 20.43 & 90.71 & 0.51 & 0.46 & 0.05 \\
\hline 173.80 & 20.57 & 90.94 & 0.51 & 0.46 & 0.05 \\
\hline 175.30 & 20.88 & 86.68 & 0.51 & 0.44 & 0.07 \\
\hline 176.00 & 21.02 & 87.25 & 0.51 & 0.44 & 0.06 \\
\hline 176.80 & 21.19 & 89.53 & 0.51 & 0.45 & 0.05 \\
\hline 177.10 & 21.25 & 92.58 & 0.48 & 0.44 & 0.04 \\
\hline 177.50 & 21.33 & 86.91 & 0.49 & 0.43 & 0.06 \\
\hline 178.30 & 21.49 & 86.71 & 0.49 & 0.42 & 0.07 \\
\hline 179.00 & 21.64 & 88.46 & 0.49 & 0.43 & 0.06 \\
\hline 179.80 & 21.80 & 76.81 & 0.49 & 0.38 & 0.11 \\
\hline 180.50 & 21.94 & 87.35 & 0.49 & 0.43 & 0.06 \\
\hline 181.30 & 22.11 & 85.81 & 0.49 & 0.42 & 0.07 \\
\hline 181.64 & 22.18 & 88.14 & 0.50 & 0.44 & 0.06 \\
\hline 182.00 & 22.25 & 87.86 & 0.50 & 0.44 & 0.06 \\
\hline 194.70 & 24.84 & 87.36 & 0.45 & 0.39 & 0.06 \\
\hline 195.40 & 24.99 & 87.35 & 0.45 & 0.39 & 0.06 \\
\hline 196.20 & 25.15 & 89.19 & 0.45 & 0.40 & 0.05 \\
\hline 196.50 & 25.21 & 88.21 & 0.45 & 0.39 & 0.05 \\
\hline 196.90 & 25.29 & 88.46 & 0.48 & 0.42 & 0.05 \\
\hline 197.70 & 25.46 & 88.17 & 0.48 & 0.42 & 0.06 \\
\hline 198.40 & 25.60 & 89.09 & 0.48 & 0.42 & 0.05 \\
\hline 199.04 & 25.73 & 91.60 & 0.48 & 0.44 & 0.04 \\
\hline 199.50 & 25.82 & 91.73 & 0.50 & 0.46 & 0.04 \\
\hline 199.90 & 25.90 & 90.05 & 0.53 & 0.47 & 0.05 \\
\hline 200.70 & 26.07 & 90.46 & 0.53 & 0.48 & 0.05 \\
\hline 202.40 & 26.42 & 91.03 & 0.54 & 0.49 & 0.05 \\
\hline 204.40 & 26.82 & 87.77 & 0.54 & 0.48 & 0.07 \\
\hline 205.10 & 26.97 & 87.77 & 0.54 & 0.48 & 0.07 \\
\hline 205.90 & 27.13 & 87.20 & 0.54 & 0.47 & 0.07 \\
\hline 206.23 & 27.20 & 91.16 & 0.54 & 0.50 & 0.05 \\
\hline 206.60 & 27.27 & 87.60 & 0.55 & 0.48 & 0.07 \\
\hline 207.40 & 27.44 & 86.36 & 0.55 & 0.47 & 0.07 \\
\hline 207.72 & 27.50 & 90.46 & 0.57 & 0.51 & 0.05 \\
\hline 208.10 & 27.58 & 89.09 & 0.57 & 0.50 & 0.06 \\
\hline 208.90 & 27.74 & 89.44 & 0.57 & 0.51 & 0.06 \\
\hline 209.60 & 27.89 & 88.76 & 0.57 & 0.50 & 0.06 \\
\hline 210.40 & 28.05 & 89.40 & 0.57 & 0.51 & 0.06 \\
\hline 211.10 & 28.19 & 88.81 & 0.57 & 0.50 & 0.06 \\
\hline 211.90 & 28.35 & 85.65 & 0.57 & 0.48 & 0.08 \\
\hline 212.23 & 28.42 & 88.42 & 0.58 & 0.52 & 0.07 \\
\hline 212.60 & 28.50 & 89.61 & 0.53 & 0.48 & 0.06 \\
\hline 214.10 & 28.80 & 86.94 & 0.53 & 0.46 & 0.07 \\
\hline 214.80 & 28.95 & 88.57 & 0.55 & 0.49 & 0.06 \\
\hline 223.60 & 30.74 & 89.99 & 0.59 & 0.53 & 0.06 \\
\hline 224.30 & 30.89 & 89.34 & 0.59 & 0.53 & 0.06 \\
\hline 226.60 & 31.36 & 89.97 & 0.59 & 0.53 & 0.06 \\
\hline
\end{tabular}




\section{APPENDIX B}

In this appendix, we present a more detailed description of the age models (Figs. 2-4) that we used in this study. Because of the strong dependence of the MAR calculations on estimates of sedimentation rate, we include this discussion to help in comparisons of this and other data sets.

The Pliocene-Pleistocene of Holes 708A, 710A, and 711A

\section{Hole 708A}

Only a single hole was cored at this site because of the extensive occurrence of turbidites and slumps. To estimate the true pelagic flux to this site better, we subtracted out all turbidites thicker than $0.4 \mathrm{~m}$ (see Appendix A for original and recalculated sub-bottom depths). The resulting age model for Hole 708A is shown in Figure 2. Our subtraction of the thicker turbidites results in a section reduced by about $26 \%$. We estimate that if all shorter turbidite intervals were recognized and subtracted from the column, the resulting section would be shortened by as much as $35 \%-40 \%$, so the sedimentation rates for this site (Table 1) are almost certainly too high.

If we uniformly decreased the rates in Hole $708 \mathrm{~A}$ by an additional $10 \%-15 \%$, values would be obtained that are nearly identical to or slightly lower than those obtained at nearby Site 710 . Although such a procedure was not followed, the resulting values would be more in line with the $285-\mathrm{m}$ deeper location of Site 708 relative to Site 710 .

Only three samples were analyzed in the interval of poor recovery below the last occurrence (LO) of Discoaster quinqueramus at $51 \mathrm{mbsf}$ and above the first occurrence (FO) of Amaurolithus spp. at $74.5 \mathrm{mbsf}$ (recalculated depths). We have chosen to extrapolate the sedimentation rate obtained above the $51 \mathrm{mbsf}$ level downward to $58.83 \mathrm{mbsf}$ rather than to use interpolated values between 51 and 74.5 mbsf.

\section{Hole $710 \mathrm{~A}$}

We estimate that about $30 \%$ of the record of the past $5 \mathrm{~m} . \mathrm{y}$. is missing in Hole 710A because of sediment loss at a core boundary and poor recovery in Core $115-710 \mathrm{~A}-3 \mathrm{H}$. The Brunhes age sediments are also 1.2 $\mathrm{m}$ thinner in Hole 710A than in 710B, again indicating some loss of sediment. The age control for Hole 710A (Fig. 2) is principally based on magnetostratigraphy, although the LOs of Discoaster brouweri (18.5 mbsf) and Discoaster tamalis (22.2 mbsf) provided important datums. The Gilbert Subchron boundaries (Fig. 2) do not fall precisely on the suggested sedimentation rate line. Plotting these boundaries from Hole $710 \mathrm{~B}$ and correcting for sediment loss between Cores 115-710B-4H and $5 \mathrm{H}$ with the use of magnetic susceptibility data, however, yields a perfect fit, implying that some stretching and/or compression has affected Core $115-710 \mathrm{~A}-4 \mathrm{H}$.

The sedimentation rate calculated from the Gilbert Subchron boundaries in Core $115-710 \mathrm{~A}-4 \mathrm{H}$ was extrapolated upward to the top of that core, rather than resorting to interpolation across the core boundary and the interval of no recovery in Core $115-710 \mathrm{~A}-3 \mathrm{H}$. This particular decision is supported by our observation that Reticulofenestra pseudoumbilica, which has an extinction age of $3.56 \mathrm{Ma}$, is present throughout Core $115-710 \mathrm{~A}-4 \mathrm{H}$. Interpolation across the core boundary between Cores $115-710 \mathrm{~A}-3 \mathrm{H}$ and $-4 \mathrm{H}$ would place the $3.56-\mathrm{Ma}$ horizon within Core $115-710 \mathrm{~A}-4 \mathrm{H}$, a clear contradiction.

\section{Hole $711 \mathrm{~A}$}

Sediments representing approximately 0.5 m.y. of deposition were lost at the boundary between Cores $115-711 \mathrm{~A}-1 \mathrm{H}$ and $-2 \mathrm{H}(8.1 \mathrm{mbsf})$. Core $115-711 \mathrm{~A}-2 \mathrm{H}$ contained only a single recognizable age datum (the LO of Calcidiscus macintyrei). Careful comparison of the magnetic susceptibility records between Holes 711A and 711B, however, yielded a second unambiguous age indication in Core 115-711 A- $2 \mathrm{H}$, the top of the Olduvai Subchron at $9.8 \mathrm{mbsf}$, as inferred from its position in Hole 711B (9.1 mbsf).

An age/depth plot of all of the magnetic reversal boundaries between the top of the Olduvai $(1.66 \mathrm{Ma})$ and the base of the Thvera (4.77 $\mathrm{Ma})$ in Hole 711B clearly suggests a constant sedimentation rate $(3.4 \mathrm{~m} /$ m.y.), with a change to a higher rate $(5.1 \mathrm{~m} / \mathrm{m} . \mathrm{y}$.) above the Olduvai based on the $C$. macintyrei extinction. Thus, the rate change indicated at $9.8 \mathrm{mbsf}$ in Hole 711 A (Fig. 2) is justified from the age/depth relationships observed in Hole 711B.
The sedimentation rate above the change at $9.8 \mathrm{mbsf}$ is calculated to be $5.7 \mathrm{~m} / \mathrm{m} . \mathrm{y}$., using the C. macintyrei extinction in Hole 711A (Fig. 2), and to be $3.4 \mathrm{~m} / \mathrm{m} . \mathrm{y}$. below the inferred top of the Olduvai down to the base of the Thvera. The nearly identical rates found in this interval for the two holes, and the good magnetostratigraphic control in Hole 711B, indicate that the age model in Hole $711 \mathrm{~A}$ is fairly accurate.

As a result of the low sedimentation rates at Site 711, the sediment loss in Core $115-711 \mathrm{~A}-2 \mathrm{H}$ (only $52.4 \%$ recovery) results in a comparatively large time gap, with no sample representation between $2.6 \mathrm{Ma}$ and 4.1 Ma. Curry et al. (this volume) have produced a high-resolution carbonate stratigraphy from this interval in Hole 711B. Judging from that study, and from the shipboard analyses of dry-bulk densities, it appears that we have not lost any significant information in our low-resolution MAR calculations from Hole 711A; in fact, the values calculated from Hole 711B are intermediate to those calculated at the 2.6- and 4.1-Ma horizons in Hole 711A.

\section{The Neogene of Holes 707A through 711A}

Neogene sedimentation rates for the five-site depth transect of Leg 115 are shown in Figure 3. This figure excludes the age/depth data for the Pliocene-Pleistocene intervals of the three sites discussed above, for which it was felt that a separate, expanded scale was desirable.

\section{Holes 707A and 709A}

Considering the much deeper location of Site 709 (3038 m) relative to Site $707(1541 \mathrm{~m})$, the striking similarity between their sedimentation rate curves for the late Neogene is perhaps surprising. Assuming a similar history of pelagic input at both sites, the greater potential for carbonate dissolution at the deeper site, and given shipboard observations of the rather coarse texture of late Neogene sediments at Site 707, one is led to conclude that winnowing has probably reduced accumulation rates at Site 707 to the point where they approximately match those at Site 709 . The relatively constant sedimentation rates obtained for the early Neogene of Site 707 (Fig. 3) are also probably not as continuous and uncomplicated as shown. In fact, it appears rather likely that the early Neogene section between $\sim 13.6$ and 25.2 Ma contains more variable rates than indicated, and probably even some hiatuses of short duration (see Rio et al., this volume). The lack of sufficient biostratigraphic resolution, and the inadequate chronological control for several of the existing index fossils, currently prevents more detailed reconstructions of the Neogene depositional history at this site.

Two datums in Holes 707A and 709A have nearly identical sub-bottom depth values, namely the FO of Catinaster coalitus (116.25 mbsf in Hole 707A and 116.42 mbsf in Hole 709A) and the LO of Sphenolithus heteromorphus (122.65 mbsf in Hole 707A and 122.40 mbsf in Hole $709 \mathrm{~A})$. In Figure 3, they are plotted as single points. Sedimentation rates obtained from Hole 709A are fairly uncomplicated down to a depth of about 123 mbsf. Below that level, however, the nannofossil biostratigraphy of Site 709 revealed the existence of a clearly disturbed interval of sediments, beginning shortly below the LO of $S$. heteromorphus, with older zones repeatedly found to overlie younger ones. In addition, magnetic susceptibility data indicate the presence of a hiatus in Hole $709 \mathrm{~A}$ relative to Hole $709 \mathrm{C}$ at about $123.5 \mathrm{mbsf}$. An ordered stratigraphy in Hole $709 \mathrm{~A}$ is regained at about 170 mbsf and is found from there downward. Consequently, we have omitted all data between 122.97 and 174.75 mbsf in Hole 709A.

\section{Hole $708 \mathrm{~A}$}

Sedimentation rates for the early Neogene of Hole 708A are poorly constrained because of the common occurrence of slumps and turbidites and the effects of enhanced carbonate dissolution on zonal markers, particularly in the middle and late early Miocene. The exact duration of the early Miocene hiatus indicated in Figure 3 is poorly determined; the duration shown should probably be regarded as a minimum value, making the early Miocene sedimentation rates highly tentative.

\section{Hole 710A}

Neogene sedimentation rates in Hole $710 \mathrm{~A}$ are fairly well constrained back to about $22.4 \mathrm{Ma}(22.35 \mathrm{Ma}$; base C6AAN2) by numerous, and presumably unambiguously identified, magnetic reversal boundaries. Obvious evidence for slumping at this site during middle Miocene times, however, forced us to omit data between $11.6 \mathrm{Ma}$ ( $92.45 \mathrm{mbsf})$ and 13.9 Ma ( $97.15 \mathrm{mbsf})$. The presence of scattered turbidites between 97.15 
and about 110 mbsf has probably created sedimentation rates slightly too high for this interval, despite the fact that all intermediate reversal boundaries fit the curve produced by those control points shown in Figure 3.

The loss of the polarity history in Hole $710 \mathrm{~A}$ at $124.9 \mathrm{mbsf}$, the point where coring was switched from the APC to XCB mode, is unfortunate because it made interpolation necessary over a critical 3-m.y.long interval (22.4-25.2 Ma). As a result, it is impossible to say exactly where the important rate change around the Miocene/Oligocene boundary occurs, although our 22.4-Ma estimate for this change in sedimentation rate cannot be younger. Another consequence of this observation from the basal Miocene at Site 710 is that it further highlights the poor age control in Hole 708A. A similar change in sedimentation rate would be expected in Hole 708 A at an age not younger than $22.4 \mathrm{Ma}$, yet the change was estimated to occur there at about $20.0 \mathrm{Ma}$.

\section{Hole 711A}

Site 711 was apparently located at a depth near or below the CCD throughout most of the Miocene, resulting in a limited number of biostratigraphic control points available for use. Moreover, we have no magnetostratigraphic boundaries in Hole $711 \mathrm{~A}$ to work with between 6.7 and $25.5 \mathrm{Ma}$. To capture the gross pattern of variability in sedimentation rates for Hole $711 \mathrm{~A}$, we were forced to rely heavily on information from Hole 711B that contained numerous Miocene magnetostratigraphic control points. Sedimentation rate estimates from both holes are presented in Figure 3 to illustrate our use of data from Hole 711B in establishing an age model for Hole 711A.

Late and late middle Miocene sedimentation rates in Hole 711B, which are well constrained by a large number of magnetic reversal boundaries, clearly indicate a downhole decrease in sedimentation rates at $8.2 \mathrm{Ma}(8.21 \mathrm{Ma}$; base C4AN1). This rate decrease is associated with a pronounced drop in carbonate content ( $w t \%)$. An additional magnetostratigraphically constrained rate change occurs at $12.8 \mathrm{Ma}(12.83$ $\mathrm{Ma}$; top C5AAN) in Hole 711B. The highest occurrence of $S$. heteromorphus (extinction at $13.6 \mathrm{Ma}$ ) is found at the base of a carbonatebarren interval in both holes $(48.70 \mathrm{mbsf}$ in Hole 711A and $46.14 \mathrm{mbsf}$ in Hole 711B), suggesting that its true LO level probably occurs slightly higher than shown in Figure 3. The lowest occurrence of $S$. heteromorphus (appearance at $18.4 \mathrm{Ma}$ ) is also observed in both holes adjacent to a carbonate-barren interval, this time at the top $(56.70 \mathrm{mbsf}$ in Hole $711 \mathrm{~A}$ and $54.00 \mathrm{mbsf}$ in Hole $711 \mathrm{~B}$ ), implying that the true FO of this taxon occurs slightly lower than shown. Hole 711B data indicate another clear sedimentation rate change in the early Miocene at $22.6 \mathrm{Ma}$ $(22.57 \mathrm{Ma}$; top $\mathrm{C} 6 \mathrm{BN})$, at a level where interpretable polarity zones reappear in the sequence. Like the rate change at $8.2 \mathrm{Ma}$, an associated change in carbonate content is observed, with sedimentation rates and carbonate showing marked increases downhole.

Because we lack magnetic susceptibility data from Hole 711B below $31 \mathrm{mbsf}$, we had to use other criteria to establish correlations between Hole 711A, from which the carbonate data is available, and Hole 711B, where sedimentation rates are much better constrained. This procedure was necessary given that data directly available from Hole 711A gave sedimentation rates very different (erroneously so, in our opinion) from those obtained in Hole 711B.

Beginning in the upper part of the Miocene section and then working downhole, our first problem was to establish a control point below the top of C4N1 in Hole 711A (33.8 mbsf/6.7 Ma) that would allow us to identify the level associated with the clear change in sedimentation rate found at $8.2 \mathrm{Ma}$ (base C4AN1) in Hole 711B. Visual correlation of a distinctive turbidite layer provided that extra control point in Hole $711 \mathrm{~A}$. The base of this turbidite is located at $36.30 \mathrm{mbsf}$ in Hole 711B and at $37.78 \mathrm{mbsf}$ in Hole 711 A (marked "T" in Fig. 3). In both holes, this " $\mathrm{T}$ "-turbidite is observed to occur shortly above the color transition from light-colored, carbonate-bearing sediments to darker, nearly carbonate-free sediments. Another thin, but less distinctive, turbidite layer occurs some $70 \mathrm{~cm}$ below the " $\mathrm{T}$ "-turbidite in each hole, lending confidence to our correlation and assumptions of synchroneity.

Bracketed by reversal boundaries, the age of the "T"-turbidite in Hole 711B was estimated via linear interpolation to be $7.8 \mathrm{Ma}$, a figure then used as the age estimate for the $37.78 \mathrm{mbsf}$ level in Hole 711A. Given that the change in sedimentation rate at $8.2 \mathrm{Ma}$ is so well constrained in Hole $711 \mathrm{~B}$, we then simply extrapolated the rate obtained above the "T"-turbidite at 7.8 Ma downward to what we presumed to be the 8.2-Ma level in Hole 711A. The latter age was thus estimated to occur at a sub-bottom depth of $39.64 \mathrm{mbsf}$ in Hole 711A. This somewhat hypothetical control point at $39.64 \mathrm{mbsf} / 8.2 \mathrm{Ma}$ then becomes one of the points used for calculations over the next deeper interval in Hole $711 \mathrm{~A}$ (see point marked A1 in Fig. 3).

Information provided by $S$. heteromorphus is important because the stratigraphic separation of its highest and lowest occurrences is nearly equal in the two holes ( $2.54 \mathrm{~m}$ and $2.70 \mathrm{~m}$, respectively). We adopted an average separation of $2.6 \mathrm{~m}$ and inferred a hypothetical top for C5AAN at $46.1 \mathrm{mbsf}$ in Hole $711 \mathrm{~A}$, which is $2.6 \mathrm{~m}$ below its position in Hole $711 \mathrm{~B}$ ( $43.5 \mathrm{mbsf} / 12.8 \mathrm{Ma}$ ). This control point at $46.1 \mathrm{mbsf} / 12.8 \mathrm{Ma}$ is marked A2 in Figure 3. Interpolation could then be used to determine sedimentation rates between control points $\mathrm{A} 1$ and $\mathrm{A} 2$. Finally, we used the top of C5AAN and the top of C6BN $(64.6 \mathrm{mbsf} / 22.57 \mathrm{Ma})$ in Hole $711 \mathrm{~B}$ to calculate an interval rate and then transferred this rate to Hole $711 \mathrm{~A}$. In doing so, we added $2.6 \mathrm{~m}$ to the 43.5 and $64.6 \mathrm{~m}$ sub-bottom depths in Hole 711B so that we could derive corrected sub-bottom depths for these time horizons in Hole 711A.

A time gap is introduced in the earliest Miocene/latest Oligocene because of poor recovery in Core $115-711 \mathrm{~A}-8 \mathrm{H}$ (only $40.2 \%$ ) and our rejection of data from the upper part of Core 115-711A-9H based on clear visual evidence for sediment slumping.

\section{The Paleogene of Holes 707A through 711A}

The top of C9N1 (28.15 Ma) at Site 711 is the oldest paleomagnetic control point available in any of the Leg 115 sites, implying that the $\mathrm{Pa}$ leogene age models discussed here, by and large, are based on biochronology. A number of factors pertinent to the Paleogene combine to result in sedimentation rates than are less well constrained than in the Neogene. These factors include the following:

1. The total number of available biostratigraphic markers is considerably less in the Paleogene interval from about 25 to $50 \mathrm{Ma}$ than in the Neogene, which is partly caused by the near absence of planktonic foraminifers in most of the Paleogene intervals cored during Leg 115, but is mostly a consequence of the Oligocene having the lowest biostratigraphic resolution of all Cenozoic epochs.

2. Taxonomic problems plague the key nannofossil lineage used in Oligocene biostratigraphy (i.e., sphenoliths; see Okada, this volume).

3. Most Paleogene marker events have been correlated to magnetostratigraphy in just a few sections from predominantly extratropical regions, which leads to questions about the accuracy of the age estimates used.

The last point can be highlighted by considering the adopted estimate for the LO of Sphenolithus distentus at $28.2 \mathrm{Ma}$, derived from studies of the middle latitude South Atlantic (see Berggren et al., 1985b). One could, in fact, make the case here for an estimate of 27.4$27.5 \mathrm{Ma}$, on the basis of its LO in tropical Hole 711A. Pending further investigation, however, we have retained the estimate of $28.2 \mathrm{Ma}$ in our calculations.

\section{Holes 707A, 708A, and 709A/709C}

The sedimentation rates in Hole 707A are interpreted to be relatively straightforward (Fig. 4); a uniform rate was used throughout the Paleogene up to the LO of Sphenolithus ciperoensis at $25.2 \mathrm{Ma}$, which we consider to be a reliable key marker in all sections. The other key marker used in Hole 707A is the LO of Discoaster barbadiensis at $37.0 \mathrm{Ma}$, and the rate obtained between these two markers is extrapolated below the latter to the base of the hole. The resulting sedimentation rate line fits the important Hantkenina datum at the Eocene/Oligocene boundary and falls midway between the FOs of $S$. distentus and $S$. aff. distentus. The FO level of $S$. ciperoensis is obscured in an interval of no recovery. The LO of $S$. distentus is clearly offset relative to the adopted sedimentation rate (Fig. 4), which would seem to suggest that the transition from the higher rates characteristic of the Paleogene to the lower early Neogene rates is really more subtle than we have shown. We have not tried to account for this datum in Figure 4, however, because it appears to be younger in the tropics, and because the rate line we have chosen only falls $0.2 \mathrm{~m} . \mathrm{y}$. from the younger estimate.

A uniform sedimentation rate is also assumed for the Paleogene of the turbidite-riddled Hole 708A, a rate which nonetheless fits all of the available markers. The depth uncertainty for the LO position of $S$. distentus is large enough to encompass both the younger and older age es- 
timates derived from the sedimentation rate line in Figure 4. We considered the chronologic reliability of the FO of $S$. ciperoensis at $30.2 \mathrm{Ma}$ to be suspect enough that we did not pursue this datum for purposes of having a second Oligocene control point. Another alternative for obtaining an additional Paleogene marker would be to consider the suggested P20/P21 zonal boundary referenced in the Leg 115 Initial Reports (depth range between 155.3 and 166.4 mbsf, at $31.6 \mathrm{Ma}$ ). Attempts to use this datum are not satisfactory either since they yield either an Eocene age at the base of Hole 708A, which cannot be true as $S$. distentus is present there, or changes in the sedimentation rate that cannot be confirmed with the available data.

We tentatively interpreted the magnetic polarity zones in Cores 115 709A-20 H and $-21 \mathrm{H}$ (see Schneider and Kent, this volume) to establish age/depth control points and sedimentation rates in the early Miocene portion of Hole 709A. The resulting rate is extrapolated upward to shortly below the disturbed section at $174.75 \mathrm{mbsf}$, which has an estimated age of $21.7 \mathrm{Ma}$. Since direct age controls are missing in the early Miocene section above $187.20 \mathrm{mbsf} / 23.8 \mathrm{Ma}(23.79 \mathrm{Ma}$; base $\mathrm{C} 6 \mathrm{CN} 3)$, it proved impossible to identify the change in sedimentation rate observed at $22.4 \mathrm{Ma}$ in Hole $710 \mathrm{~A}$ and presumed to occur in Hole $709 \mathrm{~A}$ as well. Our attempts to patch the record of Hole $709 \mathrm{C}$ onto the base of Hole 709A resulted in a minor age/depth discrepancy. Available Oligocene markers fit the sedimentation rate function well, with the exception of the LO of $S$. distentus, which nonetheless fits if the younger age estimate for its occurrence (27.4-27.5 Ma) is used. Eocene sedimentation rates at Site 709 are almost certainly better constrained than the Oligocene rates, although alternatives do exist for the rate interpretations we have shown for the middle Eocene (Fig. 4).

\section{Hole $710 \mathrm{~A}$}

Hole $710 \mathrm{~A}$ ends in sediment of early Oligocene age, which implies that we have used the two rather poorly constrained datum events of the LO of S. distentus and the FO of S. ciperoensis. The latter datum fits the sedimentation rate curve for Hole $709 \mathrm{C}$, which was established independently of its age/depth position, but which appears to be about 1 m.y. too "old" relative to the rate adopted for Hole 711A. The Oligocene sedimentation rates calculated for Hole $710 \mathrm{~A}$ are $4 \%$ higher during the interval between 25.2 and $28.2 \mathrm{Ma}$ and $17 \%$ higher between 28.2 and $30.2 \mathrm{Ma}$ than they are for comparable intervals in shallower Hole $709 \mathrm{C}$. Assuming similar pelagic input to the two sites and the likely effect of decreased dissolution rates at the shallower one, the higher sedimentation rates in Hole $710 \mathrm{~A}$ must imply either insufficient age con- trols, the respective influences of winnowing and downslope transport, or a combination of the two.

\section{Hole 711A}

Paleogene sedimentation rates estimated for Hole 711A are the consequence of interpolation over long intervals (Fig. 4). Therefore, it seems likely that the actual rates are much more variable than shown, although no major departures from the interpolated rates are anticipated given our experience with the other sites.

\section{The Neogene of Hole 714A (Maldives)}

A virtually complete early late Miocene through latest Oligocene section was cored at Site 714, a site situated on the eastern shoulder of the Maldives Ridge at a shallow water depth of $2031 \mathrm{~m}$. Although geographically far removed from our five-site depth transect, carbonate data and MAR estimates from this site are included for comparative purposes in this report.

The uppermost $19.4 \mathrm{~m}$ of the section in Hole $714 \mathrm{~A}$ are late Pleistocene in age (Table 1). At the 19.4- mbsf level, a sharp lithologic contact represents a hiatus spanning the time interval from 0.5 to $7.5 \mathrm{Ma}$. The underlying Miocene section was found to be too weakly magnetized to yield reliable polarity information, which was unfortunate given that all major microfossil groups are present and well preserved through a large portion of the early late, the middle, and the early Miocene. To provide MAR data consistent with that calculated for the transect sites, we followed a similar practice of using nannofossil data to estimate sedimentation rates. A major change in sedimentation rate in Hole 714A seems to occur in the late early Miocene, at the entry level of S. heteromorphus at $18.4 \mathrm{Ma}$ (163.15 mbsf). Sedimentation rates above this change are considered to be well constrained by biostratigraphy. The LO of $S$. ciperoensis ( $25.2 \mathrm{Ma} / 196.45 \mathrm{mbsf})$ is used as the next deeper control point. With no reliable intermediate control, we were forced to assume uniform sedimentation rates over a nearly 7 -m.y.-long time interval. Though not a particularly attractive assumption, data from other microfossil groups failed to provide additional consistent control points in this interval. If we use the LO of the planktonic foraminifer Globorotalia kugleri, for example, a slightly higher sedimentation rate in the late early Miocene is indicated. The FO level of this foraminifer species, however, which has an age estimate some $1.5 \mathrm{~m}$.y. younger than the $S$. ciperoensis datum, was observed below the latter event in the section. If nothing else, such inconsistencies illustrate the need for improved correlations between the various microfossil groups. 